ANGÉLICA CRISTINE DE ALMEIDA CAMPOS

\title{
ESTUDO GENÉTICO DA VARIANTE DO VÍRUS DA RAIVA MANTIDA POR POPULAÇÕES DO MORCEGO HEMATÓFAGO Desmodus rotundus
}

Tese apresentada ao Programa de PósGraduação Interunidades em Biotecnologia USP/Instituto Butantan/IPT, para obtenção do Título de Doutor em Biotecnologia. 


\section{ESTUDO GENÉTICO DA VARIANTE DO VÍRUS DA RAIVA MANTIDA POR POPULAÇÕES DO MORCEGO HEMATÓFAGO Desmodus rotundus}

Tese apresentada ao Programa de PósGraduação Interunidades em Biotecnologia USP/Instituto Butantan/IPT, para obtenção do Título de Doutor em Biotecnologia.

Área de Concentração: Biotecnologia

Orientador (a): Dr ${ }^{\mathrm{a}}$ Silvana Regina Favoretto Lazarini 
DADOS DE CATALOGAÇÃO NA PUBLICAÇÃO (CIP)

Serviço de Biblioteca e Informação Biomédica do

Instituto de Ciências Biomédicas da Universidade de São Paulo

reprodução não autorizada pelo autor

Campos, Angélica Cristine de Almeida.

Estudo genético da variante do vírus da raiva mantida por populações do morcego hematófogo Desmodus rotundus / Angélica Cristine de Almeida Campos. -- São Paulo, 2011.

Orientador: Silvana Regina Favoretto.

Tese (Doutorado) - Universidade de São Paulo. Instituto de Ciências Biomédicas. Programa de Pós-Graduação Interunidades em Biotecnologia USP/IPT/Instituto Butantan. Área de concentração: Biotecnologia. Linha de pesquisa: Estudo epidemiológico e genético do vírus da raiva.

Versão do título para o inglês: Genetic study of rabies virus variant maintained by hematophagous bats Desmodus rotundus populations

Descritores: 1. Vírus da raiva 2. Morcegos (Desmodus rotundus) 3. Genomas 4. Sequenciamento genético 5. Genética 6. Filogenia (análise) I. Favoretto, Silvana Regina II. Universidade de São Paulo. Instituto de Ciências Biomédicas. Programa de Pós-Graduação Interunidades em Biotecnologia USP/IPT/Instituto Butantan III. Título. 


\section{UNIVERSIDADE DE SÃO PAULO}

Programa de Pós-Graduação Interunidades em Biotecnologia

Universidade de São Paulo, Instituto Butantan, Instituto de Pesquisas Tecnológicas

Candidato(a):

Título da Tese:

Orientador(a):
Angélica Cristine de Almeida Campos.

Estudo genético da variante do vírus da raiva mantida por populações do morcego hematófogo Desmodus rotundus .

Silvana Regina Favoretto.

A Comissão Julgadora dos trabalhos de Defesa da Tese de Doutorado, em sessão pública realizada a .... considerou

\section{( ) Aprovado(a) ( ) Reprovado(a)}

\begin{tabular}{|c|c|}
\hline Examinador(a): & $\begin{array}{l}\text { Assinatura: } \\
\text { Nome: ......... } \\
\text { Instituição: . }\end{array}$ \\
\hline Examinador(a): & $\begin{array}{l}\text { Assinatura: } \\
\text { Nome: ......... } \\
\text { Instituição: . }\end{array}$ \\
\hline Examinador(a): & $\begin{array}{l}\text { Assinatura: } \\
\text { Nome: ......... } \\
\text { Instituição: . }\end{array}$ \\
\hline Examinador(a): & $\begin{array}{l}\text { Assinatura: } \\
\text { Nome: ......... } \\
\text { Instituição: . }\end{array}$ \\
\hline Presidente: & $\begin{array}{l}\text { Assinatura: } \\
\text { Nome: ........ } \\
\text { Instituição: }\end{array}$ \\
\hline
\end{tabular}




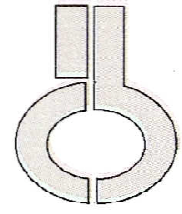

\section{UNIVERSIDADE DE SÃO PAULO INSTITUTO DE CIÊNCIAS BIOMÉDICAS}

Cidade Universitária "Armando de Salles Oliveira"

Av. Prof. Lineu Prestes, 2415 - CEP. 05508-000 São Paulo, SP - Brasil

Telefone :(55) (011) 3091.7733 - e-mail: cepatch.usp.lbs

\section{CeRTificado}

Certificamos que o protocolo registrado sob $n^{\circ} 48$ nas fls. 73 do livro 02 para uso de animais em experimentação, sob a responsabilidade do Prof(a) $\operatorname{Dr}$ (a Silvana Regina Favoretto Lazarini, Coordenador(a) da Linha de pesquisa Estudo genético da variante do virus da raiva mantida por populações do morcego hematófago Desmodus rotundus por meio do sequenciamento completo do genoma viral do qual participou(aram) o(s) alunos Angélica Cristine de Almeida Campos, está de acordo com os Princípios Éticos de Experimentação Animal adotado pela Sociedade Brasileira de Ciência de Animais de Laboratório (SBCAL) e foi aprovado pela COMISSÃO DE ÉTICA NO USO DE ANIMAIS (CEUA) em 29.06.09, com validade de 3 anos.

São Paulo, 30 de junho de 2009.

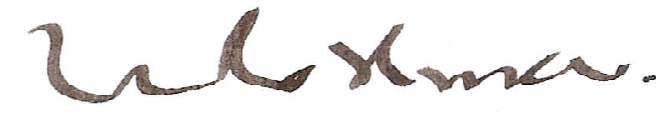

Prof.Dr.WOTHAN TAVARES DE LIMA

Coordenador

CEEA - ICB/USP

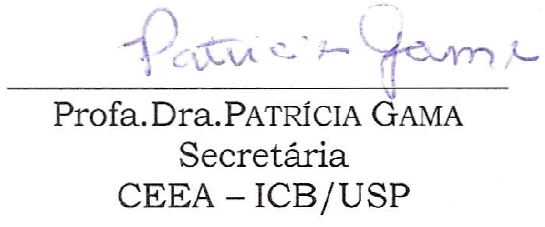


Dedico este trabalho aos grupos de pesquisa e vigilância do vírus da raiva, para que um dia esta doença possa ser mantida sob controle em todo o mundo e que a prevenção não permita que tantas pessoas e outros animais ainda morram aos milhares. 


\section{AGRADECIMENTOS}

"Agradecer é um ato aparentemente simples, mas de uma grandeza incomensurável”.

A vida, em sua maestria de complexa diversidade.

A Dr ${ }^{a}$ Silvana Regina Favoretto por aceitar que eu fosse membro do Núcleo de Pesquisas em Raiva e ser a mentora deste trabalho, orientando, ensinando, partilhando todo o conhecimento que detém além de me receber dentro de sua família. Muito obrigada!

A minha família que me apoiou desde o primeiro momento quando optei pela Biologia. Meus pais, em especial minha mãe, Marlene, exemplo de vida, meus irmãos Aline Bethânia e Adilson Jr e meu sobrinho lindo, benção em forma de criança que tornou nossas vidas mais alegres com a sua chegada.

Ao meu amado Luiz Gustavo, um furacão que entrou em minha vida, companheiro de todos os momentos, obrigada pelo amor, carinho, apoio e muita paciência. Te Amo!

Ao Prof. Dr Edison Luiz Durigon por ceder a estrutura laboratorial e à $\operatorname{Dr}^{\mathrm{a}}$ Danielle Bruna Leal por me abrir as portas do mundo da pesquisa.

Às raivosas, Danielle Bastos, Camila Seabra, Dr ${ }^{\mathrm{a}}$ Débora Sacramento, Dr ${ }^{\mathrm{a}}$ Elenice Cunha, $\mathrm{Dr}^{\mathrm{a}}$ Luzia Martorelli, Dr ${ }^{\mathrm{a}}$ Luzia Queiroz, $\operatorname{Dr}^{\mathrm{a}}$ Marilene Almeida e $\operatorname{Dr}^{\mathrm{a}}$ Ana Paula Kataoka, componentes do Núcleo de Pesquisas em Raiva.

Aos amigos e colegas do Laboratório de Virologia Clínica e Molecular (desculpem quem eu esqueci o nome): Ju Rodrigues, Claudinha, Dyana, Ariane, Carolzinha, Raquel, Priscila, Luc Thomazelli, Érika, Danila, Misa, Marina, Zezinho, Renatinha, Tati Ometto e Jansen.

Aos mais que amigos do Laboratório de Evolução Molecular e Bioinformática, muito obrigada pelo auxílio técnico e pelas risadas nas horas que eu mais precisava: Camila Romano, Fernando Melo (Frank), Âtila, Ju Velasco, Carla, Motoki e mais recentemente Julian e Dani.

As $\operatorname{Dr}^{\mathrm{a}}$ s Malu e Vivi pelas conversas, explicações, correções, puxões de orelha, almoços e muitas risadas.

Às Famílias Góes e Bentim por me acolherem em seu seio, pelos finais de semana, pelo apoio e principalmente por me presentearem com o meu amado Gustavo.

Aos professores pelas conversas nos corredores do ICB, que muitas vezes iluminou idéias obscuras: Prof. Zanotto, Prof ${ }^{a}$ Charlotte, Prof ${ }^{a}$ Dolores, Telma (mais que professora), Prof. Enrique, Prof. Althertun, Prof. Menck, Prof ${ }^{a}$ Heloísa Barbosa, Prof ${ }^{a}$ Marilis.

Aos funcionários da secretaria do Programa Interunidades em Biotecnologia Eliane, Fábia e Marcos. E aos funcionários do ICB Alice, Aninha, Naíde, Carlos, Romeu, pessoal da Faísca.

As agências CAPES pela bolsa de doutorado e FAPESP pelo auxílio à pesquisa que financiou esta Tese.

Aos morcegos e aos vírus. 
“ - Mãe!? Para que serve uma Tese?

- Uma Tese? Bem uma Tese é como um livro, a organização de resultados e conclusões de uma pesquisa. Este livro fica na biblioteca da Universidade disponível para consultas, para que todos os alunos possam ter acesso aos dados da pesquisa.

- Ah, e todos consultam a Tese de graça?

- É. A Tese é pública.

- E NÃO SERVE NEM PRÁ VENDER?!?!"

Henrique Favoretto Lazarini Agosto de 2006 aos 9 anos de idade 


\section{RESUMO}

Campos ACA. Estudo genético da variante do vírus da raiva mantida por populações do morcego hematófago Desmodus rotundus [tese (Doutorado em Biotecnologia)]. São Paulo: Instituto de Ciências Biomédicas da Universidade de São Paulo; 2011.

Dados da Organização Mundial da Saúde (WHO) mostram que a raiva é um problema de saúde pública podendo acarretar sérios prejuízos ambientais e econômicos, a despeito da existência de vacinas eficazes de uso humano e veterinário. Segundo seu último informe, estima-se que no mundo em torno de 55.000 pessoas por ano morrem de raiva. O cão permanece como principal transmissor da raiva para o homem e também como principal vítima da doença. Nos países que conseguiram controlar a raiva em animais domésticos, o vírus se mantém circulante na natureza por meio dos animais silvestres, sendo os morcegos apontados como a segunda espécie transmissora da raiva a humanos. Os lyssavirus têm sido detectados em morcegos, em diversos continentes, sendo identificados como transmissor em dez das onze espécies de lyssavirus. Fósseis de morcego mostram sua presença há 50 milhões de anos. Mas somente em 1911, Carini relacionou pela primeira vez a raiva aos morcegos, levantando a hipótese destes serem os transmissores da doença a outros animais. Há registros de que o vírus da raiva foi isolado em pelo menos 41 das 167 espécies de morcegos brasileiras, sendo que a maioria dessas espécies está relacionada a atividades humanas com a presença destes animais próximos ao local de trabalho e moradia das pessoas. Os morcegos hematófagos Desmodus rotundus são encontrados do norte do México até a costa norte do Chile, região central da Argentina e costa do Uruguai e com exceção do Chile. Esta espécie de morcego tem sido apontada como reservatório natural do vírus da raiva nesta região. Alguns pesquisadores observaram que a raiva em morcegos não hematófagos precede a raiva bovina e em animais de estimação, sugerindo que os morcegos não hematófagos podem ser o elo entre a raiva silvestre e a raiva urbana e o fato de se detectar a variante mantida por morcegos hematófagos Desmodus rotundus em cães e gatos mostra que o papel deste morcego no ciclo da raiva não está limitado à raiva silvestre. As características dos lyssavirus adaptados a morcegos têm mostrado diferenças quando comparadas à raiva relacionada aos carnívoros, confirmando a necessidade do desenvolvimento de metodologias que permitam estudos complementares mais precisos a respeito da biologia e epidemiologia da raiva em quirópteros. A escassez de dados na literatura, até o momento, a respeito do genoma completo da variante 
do vírus da raiva mantida por populações de morcegos hematófagos Desmodus rotundus, deixa uma lacuna no entendimento da epidemiologia molecular deste vírus. A importância epidemiológica desta espécie na transmissão da raiva é inquestionável. Neste estudo foi sequenciado e analisado, o genoma da variante do vírus da raiva mantido por populações de morcego hematófago Desmodus rotundus isolado de um morcego hematófago Desmodus rotundus. A amostra, procedente de área endêmica no Estado de São Paulo, foi filogeneticamente comparada com o genoma da amostra padrão para a espécie viral 1 Rabies virus e outras amostras pertencentes ao ciclo aéreo ou terrestre de transmissão, disponíveis no GenBank, identificando possíveis padrões de diferenciação, próprios do ciclo aéreo, e em alguns casos relacionados somente à variante estudada.

Palavras chave: Vírus da raiva. Desmodus rotundus. Sequenciamento. Genoma viral. Estudo genético. 


\begin{abstract}
Campos ACA. Genetic study from rabies vírus variant maintained by hematophagous bats Desmodus rotundus population [Ph. D. Thesis (Biotechnology)]. São Paulo: Instituto de Ciências Biomédicas da Universidade de São Paulo; 2011.
\end{abstract}

Data from the World Health Organization (WHO) show that rabies is a public health problem which can cause serious environmental and economic damage, despite the existence of effective vaccines for human and veterinary use. According to WHO latest report, estimated that worldwide around 55,000 people per year died of rabies. The dog remains the main transmitter of rabies to humans as well as the main victim of the disease. In countries that were successful in controlling rabies in domestic animals, the virus is still circulating in nature by wild animals and the bats are seen as the second species transmitting rabies to humans.

The lyssavirus have been detected in bats in several continents and is identified as a transmitter in ten of eleven species of lyssavirus. Bat fossils show their presence for 50 million years. But only in 1911, in the first time Carini related to rabies at bats, raising the possibility of these being the transmitters of the disease to other animals. Reports show that the rabies virus was isolated in at least 41 of the 167 species of bats in Brazil, with the majority of these species is related to human activities with the animals living near the local job and houses of people. The vampire bat Desmodus rotundus is found from northern Mexico to northern Chile coast, central coast of Argentina and Uruguay and with the exception of Chile. This bat species has been identified as a natural reservoir of the rabies virus in this region. Some researchers observed that rabies into non-hematophagous bats precedes the bovine rabies and in pets, suggesting that the non-hematophagous bats may be the link between wildlife rabies and urban rabies and the fact that detect the variant maintained by vampire bats Desmodus rotundus in dogs and cats shows that the role of bat rabies in the cycle is not limited to wildlife rabies. The characteristics of lyssavirus bat adapted have been shown differences when compared to rabies related to the carnivores, confirming the need to develop methods that enable more accurate follow-up studies about the biology and epidemiology of rabies in bats. The paucity of data in the literature to date about the complete genome of the rabies virus variant maintained by populations of vampire bats Desmodus rotundus leaves a gap in understanding the molecular epidemiology of this virus and the epidemiological importance of this species in the transmission of rabies virus is unquestionable. In this study we sequenced and analyzed the genome of the rabies virus 
variant maintained by populations of bat Desmodus rotundus isolated from a bat Desmodus rotundus. The sample, coming from an endemic area in São Paulo, was phylogenetically compared with the genome of the standard sample for spcies 1 - Rabies virus and other samples belonging to the Terrestrial and Aerial cycles of transmission, available in GenBank, to identify possible patterns of differentiating themselves Aerial cycle and in some cases linked only to variant studied.

Key words: Rabies virus. Desmodus rotundus. Sequencing. Viral genome. Genetic study. 


\section{LISTA DE ILUSTRAÇÕES}

Figura 1. Mapa das áreas de risco para o vírus da raiva no mundo ..................................................25

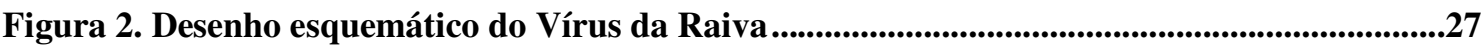

Figura 3. Desenho esquemático do mapa genômico (a) e replicação do Vírus da Raiva (b) ..........29

Figura 4. Morcego hematófago Desmodus rotundus ......................................................................31

Figura 5. Visualização da quantificação de RNA para as amostras brdrusp100/07 e brbvusp01/06. ..................................................................................................................................................48

Figura 6. Esquema da organização do genoma do Vírus da Raiva e representação da cauda Poli-

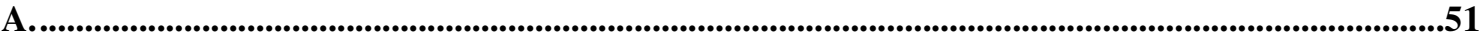

Figura 7. Eletroforese em gel de agarose 1,5\% para nucleoproteína com a amostra controle brbvusp01/06. ..........................................................................................................................................................................51

Figura 8. Eletroforese em gel de agarose 1,5\% para fosfoproteína e proteína de matriz. …..........52

Figura 9. Eletroforese em gel de agarose $1,5 \%$ para núcleo e glicoproteínas com a amostra controle brbvusp01/06 .............................................................................................................................................53

Figura 10. Eletroforese em gel de agarose 1,5\% para glicoproteína da amostra brbvusp01/06...53

Figura 11. Eletroforese em gel de agarose 1,5\% para fragmentos da polimerase viral. .................54

Figura 12. Eletroforese em gel de agarose 1,5\% fragmentos da polimerase viral. ..........................55

Figura 13. Eletroforese em gel de agarose 1,5\% para fragmentos da polimerase viral .................56

Figura 14. Eletroforese em gel de agarose $1,5 \%$ de um gradiente de temperatura para a amostra controle brbvusp01/06...........................................................................................................................................56

Figura 15. Eletroforese em gel de agarose 1,5\% para fragmentos da polimerase viral. .................57

Figura 16. Eletroforese em gel de agarose 1,5\% para fragmentos da polimerase viral. .................58

Figura 17. Eletroforese em gel de agarose $1,5 \%$ para fragmentos da polimerase viral. ..................58

Figura 18. Eletroforese em gel de agarose $1,5 \%$ para fragmentos da polimerase viral. .................59

Figura 19. Eletroforese em gel de agarose 1,5\% da amplificação do genoma completo..................60

Figura 20. Eletroforese em gel de agarose 1,0\% da amplificação do genoma completo.................61

Figura 21. Visualização da quantificação de DNA .............................................................................................62

Figura 22. Visualização da quantificação de DNA para a amostra brbvusp01/06..........................62

Figura 23. Ilustração comparativa do sítio antigênico I na região carboxi terminal da nucleoproteína N.. .......................................................................................................................................63

Figura 24. Ilustração comparativa dos sítios antigênicos localizados na glicoproteína G..............63 
Figura 25. Árvore filogenética de máxima verossimilhança (ML) para nucleoproteína (parcial) . .64

Figura 26. Árvore filogenética de máxima verossimilhança (ML) para nucleoproteína................66

Figura 27. Árvore filogenética de máxima verossimilhança (ML) para nucleoproteína. . .67

Figura 28a. Ilustração gerada pelo programa MacClade para o resíduo 377 da nucleoproteína.69 Figura 28b. Ilustração gerada pelo programa MacClade para o resíduo 379 da nucleoproteína.

Figura 28c. Ilustração gerada pelo programa MacClade para o resíduo 433 da nucleoproteína.70

Figura 29. Gráfico com frequência de aminoácidos na nucleoproteína.............................................71

Figura 30. Gráfico de substituição de aminoácidos na nucleoproteína............................................71

Figura 31. Árvore filogenética de máxima verossimilhança (ML) para a fosfoproteína.................73

Figura 32. Árvore filogenética de máxima verossimilhança (ML) para a fosfoproteína................74

Figura 33a. Ilustração gerada pelo programa MacClade para o resíduo 68 da fosfoproteína.....75 Figura 33b. Ilustração gerada pelo programa MacClade para o resíduo 112 da fosfoproteína...75

Figura 34. Gráfico com frequência de aminoácidos na fosfoproteína....................................................76

Figura 35. Gráfico de substituição de aminoácidos na fosfoproteína................................................76

Figura 36. Árvore filogenética de máxima verossimilhança (ML) para proteína de matriz..........77

Figura 37. Árvore filogenética de máxima verossimilhança (ML) para proteína de matriz.........78

Figura 38a. Ilustração gerada pelo programa MacClade para o resíduo 82 da proteína de

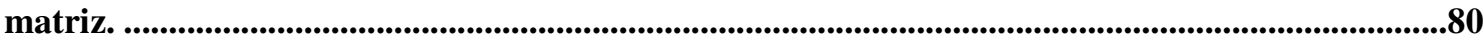
Figura 38b. Ilustração gerada pelo programa MacClade para o resíduo 148 da proteína de

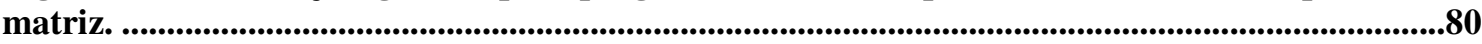
Figura 38c. Ilustração gerada pelo programa MacClade para o resíduo 184 da proteína de matriz.......................................................................................................................................................................................81

Figura 39. Gráfico com frequência de aminoácidos na proteína de matriz......................................81

Figura 40. Gráfico de substituições de aminoácidos na proteína de matriz. ......................................82

Figura 41. Árvore filogenética de máxima verossimilhança (ML) para glicoproteína...................83

Figura 42. Árvore filogenética de máxima verossimilhança (ML) para glicoproteína...................84

Figura 43a. Ilustração gerada pelo programa MacClade para o resíduo 213 da glicoproteína. ..86 Figura 43b. Ilustração gerada pelo programa MacClade para o resíduo 367 da glicoproteína. ..87 Figura 43c. Ilustração gerada pelo programa MacClade para o resíduo 475 da glicoproteína....87 Figura 43d. Ilustração gerada pelo programa MacClade para o resíduo 478 da glicoproteína. ..88

Figura 44. Gráfico com frequência de aminoácidos na glicoproteína..................................................88

Figura 45. Gráfico de substituição de aminoácidos na glicoproteína. .89 
Figura 46. Esquema das regiões sequenciadas para a polimerase viral...............................................90

Figura 47. Árvore filogenética de máxima verossimilhança (ML) para a polimerase....................90

Figura 48. Árvore filogenética de máxima verossimilhança (ML) para a polimerase....................91

Figura 49. Árvore filogenética de máxima verossimilhança (ML) para a polimerase.....................92

Figura 50. Árvore filogenética de máxima verossimilhança (ML) para a polimerase.....................93

Figura 51. Árvore filogenética de máxima verossimilhança (ML) para a polimerase....................94

Figura 52. Árvore filogenética de máxima verossimilhança (ML) para a polimerase....................95

Figura 53. Árvore filogenética de máxima verossimilhança (ML) para a polimerase....................96

Figura 54. Árvore filogenética de máxima verossimilhança (ML) para a polimerase.....................97

Figura 55. Árvore filogenética de máxima verossimilhança (ML) para a polimerase....................98

Figura 56. Árvore filogenética de máxima verossimilhança (ML) para a polimerase...................99

Figura 57. Árvore filogenética de máxima verossimilhança (ML) para a polimerase...................100

Figura 58. Árvore filogenética de máxima verossimilhança (ML) para a polimerase..................101

Figura 59. Árvore filogenética de máxima verossimilhança (ML) para a polimerase..................102

Figura 60. Árvore filogenética de máxima verossimilhança (ML) para a polimerase...................103

Figura 61. Árvore filogenética de máxima verossimilhança (ML) para a polimerase..................104

Figura 62. Árvore filogenética de máxima verossimilhança (ML) para a polimerase..................105

Figura 63. Árvore filogenética de máxima verossimilhança (ML) para a polimerase..................106

Figura 64. Árvore filogenética de máxima verossimilhança (ML) para a polimerase.................107

Figura 65a. Ilustração gerada pelo programa MacClade para o resíduo 8 da polimerase viral.

Figura 65b. Ilustração gerada pelo programa MacClade para o resíduo 645 da polimerase.....112 Figura 65c. Ilustração gerada pelo programa MacClade para o resíduo 27 da polimerase. .......112 Figura 65d. Ilustração gerada pelo programa MacClade para o resíduo 1487 da polimerase...113 Figura 65e. Ilustração gerada pelo programa MacClade, no resíduo 88 da polimerase. .113 


\section{LISTA DE TABELAS}

Tabela 1 - Descrição dos primers utilizados nas reações de RT/PCR e Sequenciamento para a nucleoproteína.

Tabela 2 - Oligonucleotídeos iniciadores para amplificação de genes do vírus da raiva.................49

Tabela 3 - Substituições de aminoácidos encontradas para a proteína $\mathrm{N}$..........................................68

Tabela 5 - Substituições de aminoácidos encontradas para a proteína M ......................................79

Tabela 6 - Substituições de aminoácidos encontradas para a proteína G.........................................85

Tabela 7 - Substituições de aminoácidos encontradas para a proteína $\mathrm{L}$..........................................108

Tabela 8 - Regiões com mais de sete resíduos de aminoácidos conservados entre as amostras estudadas e a amostra de referência PV - proteína $\mathrm{L}$..................................................................................114 


\section{LISTA DE ABREVIATURAS E SIGLAS}

ABL - Lissavirus do morcego australiano (do inglês Australian Bat Lyssavirus)

ARAV - Aravan vírus

BHK-21- linhagem celular (do inglês Baby Hamster Kidney)

brbvusp01/06 - amostra do vírus da raiva isolada de um Bovino

brdrusp100/07 - amostra do vírus da raiva isolada de um morcego hematófago Desmodus rotundus

cDNA - fita complementar ao DNA

CDC - Centro de Controle de Doenças (do inglês Centers for Disease Control and Prevention)

DEPC - Dimetilpirocarbonato

DNA - Ácido Desoxirribonucleico (do inglês Desoxy Nucleic Acid)

dNTP - Desoxirribonucleotídeos fosfatados

DUVV - Duvenhage vírus

EBLV - Lissavirus do morcego europeu (do inglês European Bat Lyssavirus)

EDTA - Ácido Etilenodiamino Tetra-Acético (do inglês Ethylenediamine tetraacetic acid)

EMEM - Meio de crescimento (do inglês Eagle's Minimum Essential Medium)

GARLi - Programa de análises filogenéticas (do inglês Genetic Algorhitm for Rapid Likelihood Inference )

ICB II-USP - Instituto de Ciências Biomédicas II da Universidade de São Paulo

IRKV - Irkut vírus

KHUV - Khujand vírus

LBV - Vírus do morcego de Lagos (do inglês Lagos bat virus)

MEGA - Programa de análises (do inglês Molecular Evolutionary Genetics Analysis Software)

MMLV - Enzima para transcrição (do inglês Moloney-Murine Leukemia Virus) 
MOKV - Mokola vírus

NCBI - Centro Nacional de Informação Biotecnologica (do inglês National Center for Biotechnology Information)

OPAS - Organização Panamericana de Saúde

PAHO - Organização Panamericana de Saúde (do inglês Panamerican Health Organization)

PCR - Reação em cadeia pela polimerase (do inglês Polymerase Chain Reaction)

pH - Potencial Hidrogeniônico

PV - Vírus Pasteur (do inglês Pasteur virus)

P\&D - Pesquisa e Desenvolvimento

RABV - Vírus da Raiva (do inglês Rabies virus)

RNA - Ácido Ribonucleico (do inglês Ribo Nucleic Acid)

RNP - Ribonucleoproteína

RT-PCR - Reação em cadeia pela polimerase precedida de transcrição

RV - Vírus da Raiva (do inglês Rabies virus)

SFB - Soro Fetal Bovino

TBE - Tampão Tris-Borato-EDTA

WCBV - Vírus do morcego caucasiano do oeste (do inglês West Caucasian bat virus)

WHO - Organização Mundial da Saúde (do inglês World Health Organization) 


\section{LISTA DE SÍMBOLOS OU FÓRMULAS}

\section{Aminoácidos}

$$
\begin{aligned}
& \text { A - Ala - Alanina } \\
& \text { C - Cys - Cisteína } \\
& \text { D - Asp - Ácido Aspártico } \\
& \text { E - Glu - Ácido Glutâmico } \\
& \text { F - Phe - Fenilalanina } \\
& \text { G - Gly - Glicina } \\
& \text { H - His - Histidina } \\
& \text { I - Ile - Isoleucina } \\
& \text { K - Lys - Lisina } \\
& \text { L - Leu - Leucina } \\
& \text { M - Met - Metionina } \\
& \text { N - Asn - Asparagina } \\
& \text { P - Pro - Prolina } \\
& \text { Q - Gln - Glutamina } \\
& \text { R - Arg - Arginina } \\
& \text { S - Ser - Serina } \\
& \text { T - Thr - Treonina } \\
& \text { V - Val - Valina } \\
& \text { Y - Tyr - Tirosina } \\
& \text { W - Trp - Triptofano }
\end{aligned}
$$

\section{Bases Nitrogenadas dos Nucletotídeos}

$$
\begin{aligned}
& \text { A - Adenina } \\
& \text { C - Citosina } \\
& \text { G - Guanina } \\
& \text { T - Timina }
\end{aligned}
$$




\section{Fórmulas}

Ca++ - íons cálcio

$\mathrm{H}_{3} \mathrm{BO}_{3}$ - Ácido Bórico

DTT - Ditiotreitol

$\mathrm{H}_{2} \mathrm{O}-$ Água

$\mathrm{KCl}$ - Cloreto de Potássio

Mg++ - íons magnésio

$\mathrm{MgCl}_{2}-$ Cloreto de Magnésio

Tris- $\mathrm{HCl}$ - Tris (hidroximetil) aminometano

\section{Símbolos}

$\Psi$ - Psi, indica a região do genoma viral chamada de Pseudogene situada entre a glicoproteína e a polimerase viral . 


\section{SUMÁRIO}

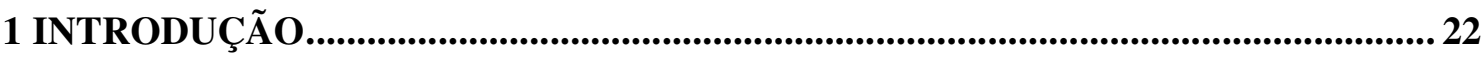

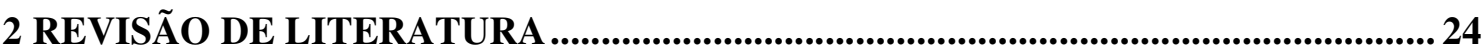

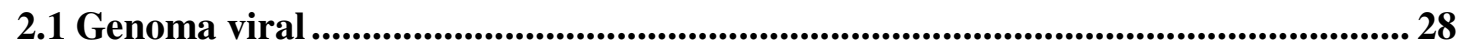

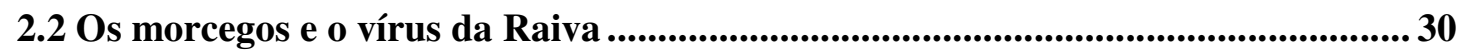

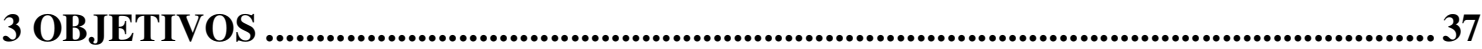

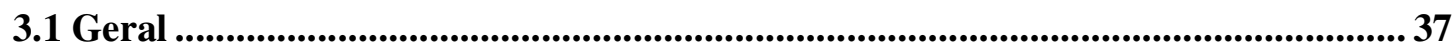

3.2 Específicos ............................................................................................................................ 37

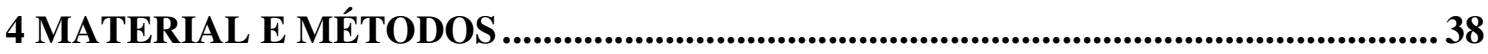

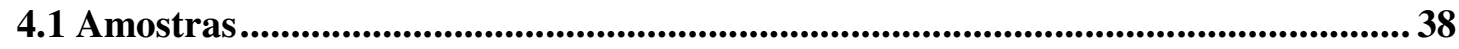

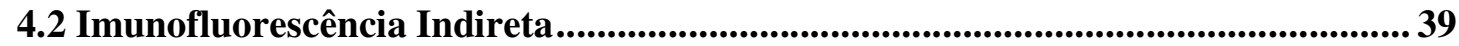

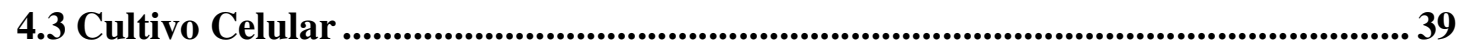

4.4 Descrição dos Oligonucleotídeos Iniciadores (primers) .............................................. 40

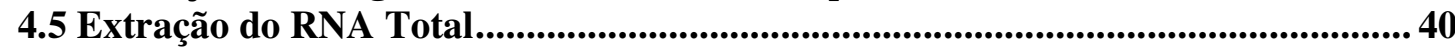

4.6 Reação em cadeia pela polimerase precedida de transcrição (RT-PCR) ................ 41

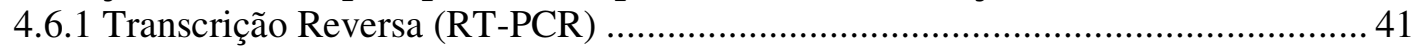

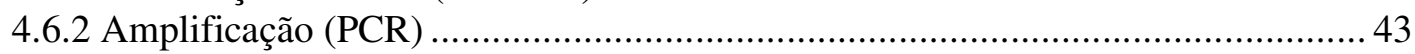

4.7 Detecção por Eletroforese dos Produtos Amplificados ............................................. 44

4.8 Purificação da Reação de Amplificação ........................................................................ 45

4.9 Reação de Sequenciamento ........................................................................................... 45

4.9.1 Purificação da reação de sequenciamento ......................................................... 46

4.9.2 Processamento e alinhamento das sequências dos genes N, P, M, G e L do vírus da

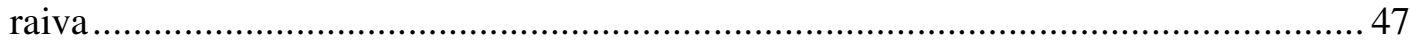

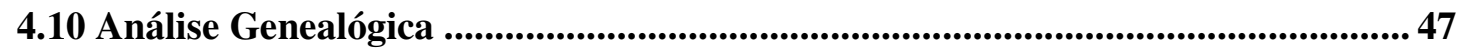

5 RESULTADOS ....................................................................................................................... 48

5.1 Imunofluorescência Indireta e Cultivo Celular................................................48

5.2 Desenho de Primers e Quantificação do RNA viral................................................... 48

5.3 Síntese de cDNA e Amplificação Viral ...................................................................50

5.4 Quantificação e Sequenciamento ...........................................................................61 6

5.5 Análises Genealógicas ....................................................................................................63

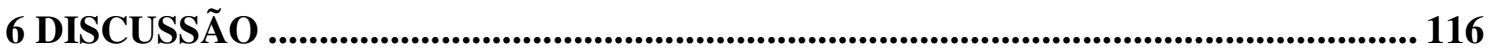

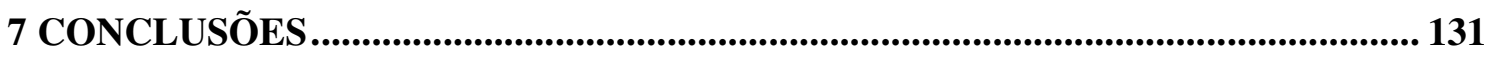

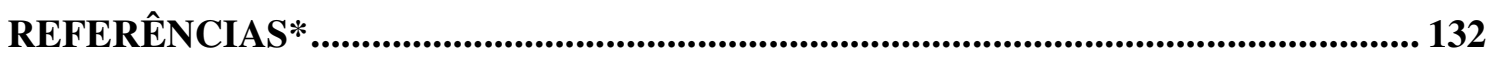

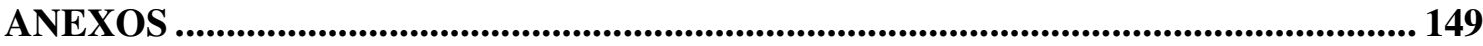

ANEXO A - Sequências utilizadas nas análises filogenéticas dos genes N, P, M, G e L

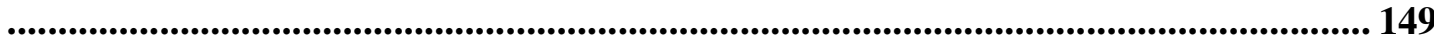

ANEXO B - Artigo enviado para publicação no Journal of Virological Methods. .... 161

ANEXO C - Premiação - Menção Honrosa .................................................................. 181 


\section{INTRODUÇÃO}

A raiva é uma doença letal conhecida desde a antiguidade, com relatos no Código de Eshnunna cerca de 1930 aC e nos escritos por Aristóteles e Hipócrates 500 aC. Democritus, também em $500 \mathrm{aC}$, fez a primeira descrição de um cão raivoso e Celsus, Século I, descreveu a Raiva em humanos. No Século XVIII a raiva foi descrita em diferentes partes da Europa, em 1703 foi descrito o primeiro relato de raiva no México e em 1803 a doença foi relatada pela primeira vez na América do Sul em humanos no Peru. Em 1804, Zinke comprovou que a saliva do cão doente era responsável pela transmissão da raiva e Pasteur com observações e experimentos desenvolveu a primeira vacina, produzida em cérebro de coelhos, a partir de passagens sucessivas do material obtido de animais contaminados.

As citações mais antigas que envolvem morcegos hematófagos foram descritas nas Américas pelos primeiros colonizadores espanhóis que chegaram ao novo mundo e relataram grandes refúgios e agressões destes morcegos a animais e homens, com registros de óbitos de soldados, como no Panamá em 1514, acontecimentos estes que certamente já ocorriam antes da colonização, mas permaneciam restritos a fauna nativa existente.

A raiva é transmitida a partir de contato direto com um animal infectado por meio de mordedura, lambedura, arranhadura, ou ainda pela formação de aerossóis em cavernas onde exista um grande número de morcegos contaminados com alta concentração de vírus. Além do cão e do morcego já foram relatadas transmissão por via oral em raposas e por transplantes de órgãos sólidos entre seres humanos.

Existem duas formas clássicas da doença, a raiva paralítica, que em virtude de ser observada predominantemente em bovinos vem sendo associada à transmissão por morcegos hematófagos e a raiva furiosa, evidente em carnívoros, geralmente relacionada à transmissão por cães. O período de incubação, ou período prodrômico, pode variar de 15 dias a anos, sendo observado no homem em média de 45 dias; com o aparecimento dos sintomas a raiva tem sido fatal com excessão de 2 casos humanos um descrito nos Estados Unidos em 2004 e outro no Brasil em 2009.

A raiva continua amplamente distribuída no mundo, com raras exceções de alguns países ou regiões, apesar da quantidade de recursos destinados ao estudo, prevenção e controle da doença. Mesmo em países onde uma estrutura sanitária desenvolvida, como no Brasil onde a campanha de vacinação em massa para cães e gatos, iniciada em 1981, contribuiu de forma decisiva para o controle da raiva no país, o controle da raiva mantida e transmitida por populações de cães e de animais silvestres ainda é um problema de saúde 
pública.

Depois de séculos de estudos, o vírus da raiva é o mais conhecido dos Lyssavirus. Mundialmente, espécies de animais silvestres que servem como reservatórios e agem como transmissores garantem a manutenção da raiva.

Ainda hoje, 126 anos depois da vacina produzida e testada por Pasteur, a raiva continua a vitimar humanos, animais de companhia e rebanhos além de animais silvestres em todo o mundo, representando um grande problema de saúde pública, tanto para países em desenvolvimento, como para os que detêm recursos e tecnologia. 


\section{REVISÃO DE LITERATURA}

O vírus da Raiva pertence à família Rhabdoviridae que, juntamente com as famílias Paramyxoviridae, Filoviridae, e Bornaviridae constituem uma "superfamília" da ordem Mononegavirales, na qual todos os membros são constituídos por uma molécula única de RNA (ssRNA) não segmentado, de polaridade negativa [Mono, do grego Monos "único, simples", Nega "de RNA polaridade negativa", Virales, do latim "vírus"] (Fauquet et al., 2004).

A família Rhabdoviridae está subdividida em dois sub-grupos de vírus de plantas, um grupo de vírus de peixe e três gêneros de vírus de mamíferos: Ephemerovirus, Vesiculovirus cujo protótipo é o vírus da estomatite vesicular-VSV e os Lyssavirus que têm como protótipo o vírus da raiva.

A partir do final de 2009 foram definidas, pelo Comitê de Taxonomia Viral - ICTV [do inglês International Committee on Taxonomy of Viruses], 11 espécies virais para o gênero Lyssavirus (ICTV, 2009). As quatro primeiras espécies (anteriormente descritas como genótipos) coincidem com os sorotipos 1 a 4 :

espécie viral Raiva - Rabies virus - mundialmente distribuída (Figura 1), compreende as amostras clássicas de vírus da raiva (RABV): as selvagens isoladas de animais e as amostras chamadas fixas ou vacinais (Tordo, 1996; Wunner, 2002).

espécie viral Lagos Bat - Lagos bat virus (LBV) - corresponde a amostra isolada pela primeira vez de um morcego frugívoro (Eidolon helvum) na Nigéria em 1956 (Boulger e Porterfield, 1958; Kuzmin et al., 2003) e de outro morcego (Micropterus pusillus) na África Central em 1974 (King e Turner, 1993).

espécie viral Mokola - Mokola virus (MOKV) - compreende a amostra isolada na África, de roedores e mussaranhos (Crocidura sp.), de cães, de crianças na Nigéria em 1968 e 1971 (Shope et al., 1970; Kemp et al., 1972; Familusi et al., 1972; Kuzmin et al., 2003) e de gatos no Zimbábue (Von Teichman, 1998; Kuzmin et al., 2003). 


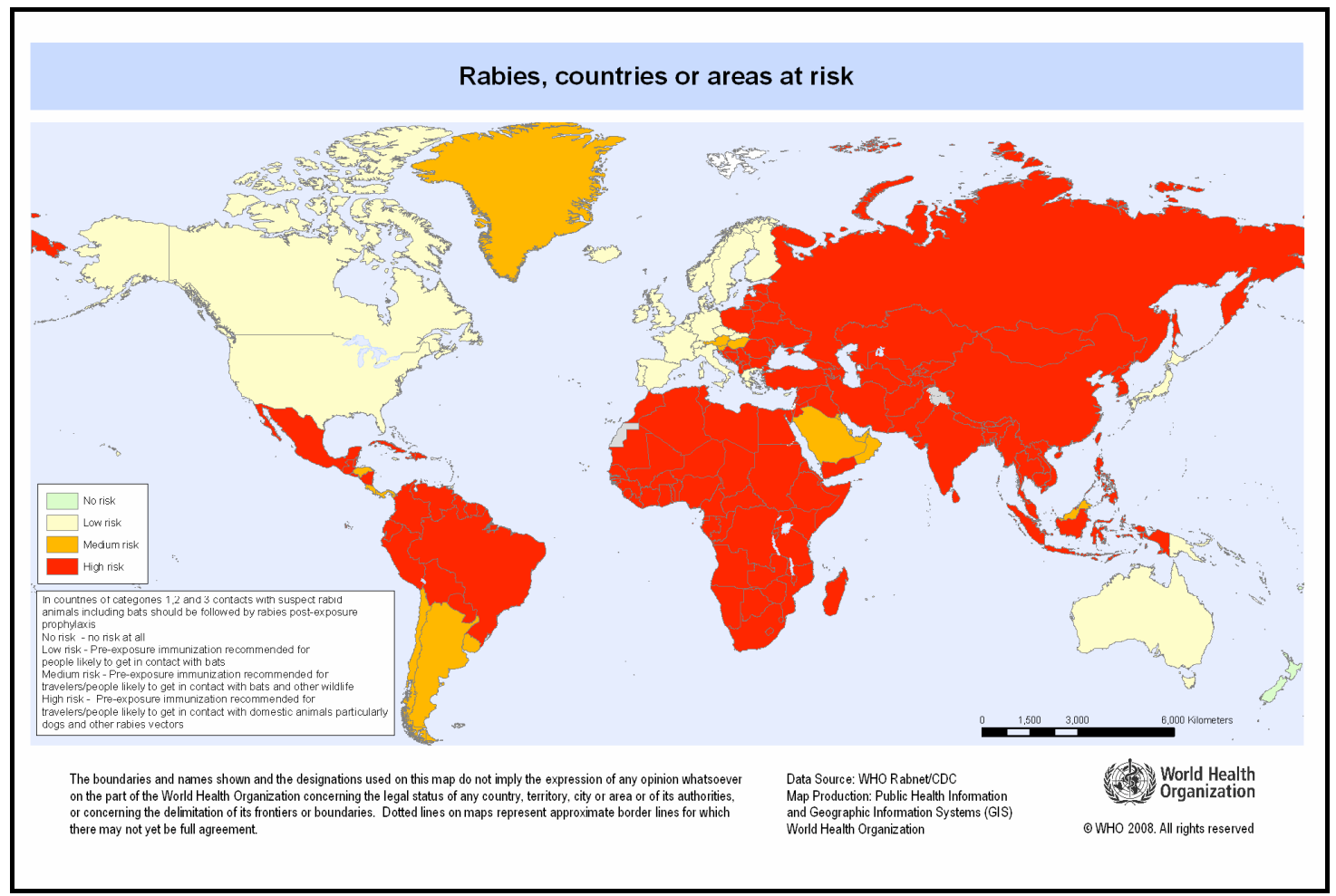

Figura 1. Mapa das áreas de risco para o vírus da raiva no mundo.

Fonte: World Health Organization. Department of Neglected Tropical Diseases (NTD), Neglected Zoonotic Diseases (NZD), 2009.

espécie viral Duvenhage - Duvenhage virus (DUVV) - corresponde ao isolado originariamente de um homem que morreu após ser mordido por um morcego na África em 1970 (Meredith et al., 1971) e posteriormente, em 1981, de um morcego Miniopterus sp. na África (Kuzmin et al., 2003).

O vírus European Bat Lyssavirus (EBLV) primeiro foi identificado como parte do antigo genótipo 4 DUVV (Schneider et al., 1985), entretanto verificou-se a existência de diferenças antigênicas que o classificaram como o antigo genótipo 5 (Dietzschold et al., 1988). Posteriormente foi subdividido em dois genótipos EBLV1 e EBLV2 (Bourhy et al., 1993) e atualmente em duas espécies virais European bat lyssavirus 1, European bat lyssavirus 2 (ICTV, 2009):

espécie viral Lissavírus do Morcego Europeu 1 - European bat lyssavirus 1 (EBLV1) identificado em morcego Eptesicus serotinus na Alemanha em 1968 (Schneider et al., 1985; Dietzschold et al., 1988; Schneider e Cox, 1994), na Polônia em 1985 (Lafon et al., 1986), na Dinamarca, Holanda e Espanha em 1987 e na França em 1989 (Bourhy et 
al., 1992). Alguns isolados do EBLV1 foram obtidos de morcegos na Ucrânia e de um caso humano relacionado a morcego na Rússia em 1985 (Selimov et al., 1989, 1991; Kuzmin et al., 2003).

espécie viral Lissavírus do Morcego Europeu 2 - European bat lyssavirus 2 (EBLV2) isolado de um humano na Finlândia em 1985 (Bourhy et al., 1993; Tordo, 1996) e em morcegos na Holanda, Suíça e Reino Unido, sendo mantido por morcegos insetívoros do gênero Myotis (King et al., 1994; Kuzmin et al., 2003).

espécie viral Lissavírus do Morcego Australiano - Australian bat lyssavirus (ABLV) responsável por casos humanos em 1996, foi também isolado de cinco espécies de morcegos raposa voadora e uma espécie de morcego insetívoro no continente Australiano (Gould et al., 1998; Fraser et al., 1996; Kuzmin et al., 2003).

Quatro novas espécies virais foram identificadas na Ásia Central, leste da Sibéria e região caucasiana (ICTV, 2009):

espécie viral Aravan - Aravan virus (ARAV) - identificada em 1991 na espécie de morcego Myotis blythi na região do Quirguistão na Ásia Central (Arai et al., 2003; Kuzmin et al., 2003).

espécie viral Khujand - Khujand virus (KHUV) - identificada em 2001 na espécie de morcego Myotis daubentoni no Tajiquistão (Kuzmin et al., 2003).

espécie viral Irkut - Irkut virus (IRKV) - identificada em 2002 na espécie de morcego Murina leucogaster na Província de Irkustk - Rússia (Kuzmin et al., 2005).

espécie viral do Morcego Caucasiano do Oeste - West Caucasian bat virus (WCBV) identificada em 2002 na espécie de morcego Miniopterus schreibersii na região de Krasnodar na Rússia (Kuzmin et al., 2005).

Kuzmin et al. (2010) identificaram o Shimoni Bat Lyssavirus em morcegos africanos e o indicam como a décima segunda espécie viral.

A primeira vacina foi produzida a partir de passagens sucessivas em cérebro de coelhos e adminstrada em 1885 por Louis Pasteur (Pasteur et al., 1881; 1882; Pasteur, 1885). Este tipo de vacina, assim como várias outras que sucederam, também produzidas a partir de tecido nervoso, causava acidentes neurológicos em virtude da presença de mielina no cérebro de animais adultos (Horack, 1939; Sellers, 1947). Somente em Fuenzalida e Palácios (1955) 
desenvolveram então uma vacina produzida em cérebro de camundongos recém-nascidos, quando o cérebro ainda não apresenta níveis consideráveis de mielina, o que reduziu o número de reações secundárias. Estas vacinas produzidas em tecido nervoso foram chamadas então de vacinas de primeira geração. Posteriormente Koprowski e Cox (1948) apresentaram os primeiros estudos das vacinas produzidas em ovos embrionados, chamadas de segunda geração. Estas vacinas apresentavam baixo poder antigênico além das reações de hipersensibilidade decorrentes das proteínas do ovo. As vacinas de terceira geração, produzidas a partir de cultivo celular, passaram a ser produzidas em meados da década de 50 (Kissling, 1958; Wiktor et al., 1964; Frazatti-Galina et al., 2004) e evoluíram sendo atualmente as mais utilizadas em virtude da eficiência e segurança. Estudos com a expressão de genes em culturas de células (dos Santos et al., 2009) abrem caminho para as novas vacinas sintéticas de subunidades e as vacinas recombinantes. $\mathrm{O}$ controle da raiva em reservatórios silvestres vem sendo mantido a partir da vacinação oral com o uso de vacinas em iscas sendo uma metodologia socialmente aceita e que pode ser aplicada em larga escala onde a vacinação parenteral é impraticável (Slate et al., 2009).

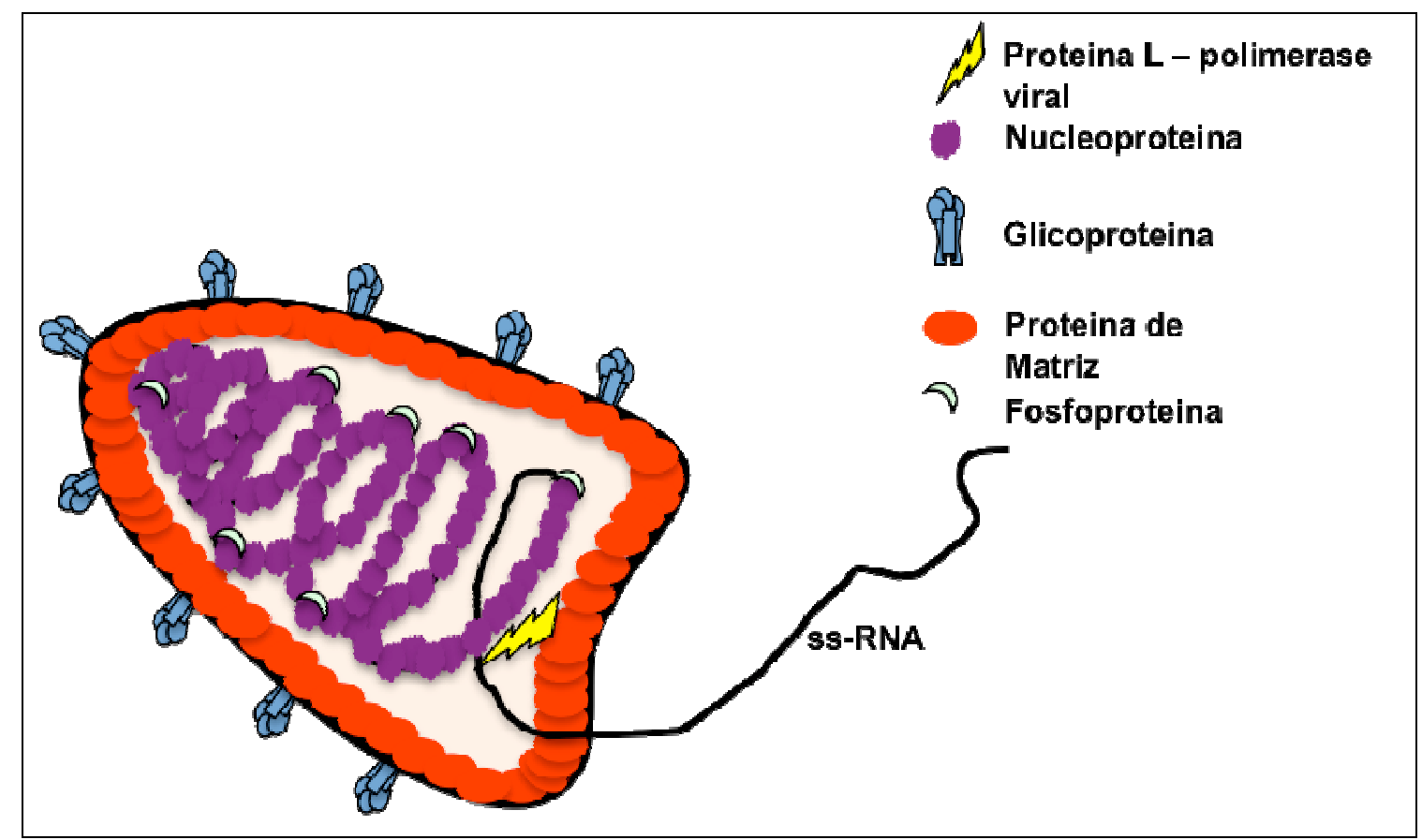

Figura 2. Desenho esquemático do Vírus da Raiva

Morfologicamente o vírus com forma de projétil, apresenta envelope lipídico, com espículas em toda a superfície do envelope, com exceção da região plana. O envelope é 
adquirido da célula hospedeira no momento da lise durante a replicação. A partícula viral possui um diâmetro médio de $75 \mathrm{~nm}(45 \mathrm{a} 100 \mathrm{~nm})$ e comprimento que varia de 100 a $300 \mathrm{~nm}$ sendo constituída por duas estruturas principais de acordo com a função, o complexo helicoidal ribonucleoproteico e o envelope viral (Fauquet et al., 2004). Os componentes virais estão representados na figura 2.

\subsection{Genoma viral}

O genoma do vírus da Raiva é de aproximadamente $12 \mathrm{~Kb}$ e codifica 5 proteínas diferentes, como pode ser observado na figura 3.

A ribonucleoproteína (nucleocapsídeo) é filamentosa, composta por uma fita simples de RNA genômico de forma helicoidal não segmentado e de senso negativo, associada à nucleoproteína ( $\mathrm{N}$ - do inglês Nucleoprotein), fosfoproteína ( $\mathrm{P}$ - do inglês Phosphoprotein) e polimerase viral (L - do inglês Large Protein) (Sokol et al., 1969; Fauquet et al., 2004).

O envelope viral é composto por uma bicamada lipídica à qual estão associadas duas proteínas, a proteína de matriz (M - do inglês Matrix Protein) e a glicoproteína ( $\mathrm{G}$ - do inglês Glycoprotein). A glicoproteína é a única proteína transmembranária e se projeta para o exterior com espículas glicosiladas constituídas por trímeros (Wunner et al., 1985; Tordo et al., 1986a). Também é responsável pela fixação da partícula viral nos receptores celulares, participando da endocitose do vírus e da fusão da membrana viral com a vesícula endossomal (Perrin et al., 1982; Gaudin et al., 1991; Gaudin, 1993).

O vírus da raiva se fixa em um ou mais receptores celulares (Perin et al., 1982; Superti et al., 1984; Wunner et al., 1984; Superti et al., 1986). Após a fixação ao receptor, a partícula viral penetra na célula por endocitose, funde-se com endossomos e pelo contato com lisossomos libera a ribonucleoproteína no citoplasma (Lentz et al., 1982). O RNA viral é transcrito em moléculas complementares positivas sequencialmente da extremidade 3' em direção a extremidade 5', produzindo primeiro um RNA leader e depois cinco RNAs mensageiros, que correspondem às proteínas N, P, M, G, e L. Em seguida, há uma segunda etapa replicativa, na qual as fitas positivas servirão de molde para a produção de fitas negativas, as quais serão encapsidadas (Banerjee, 1987). A liberação das partículas virais ocorre por brotamento nos sítios da membrana celular, onde as proteínas do envelope viral se acumularam previamente (Hummeler et al., 1967; Cox et al., 1977). 


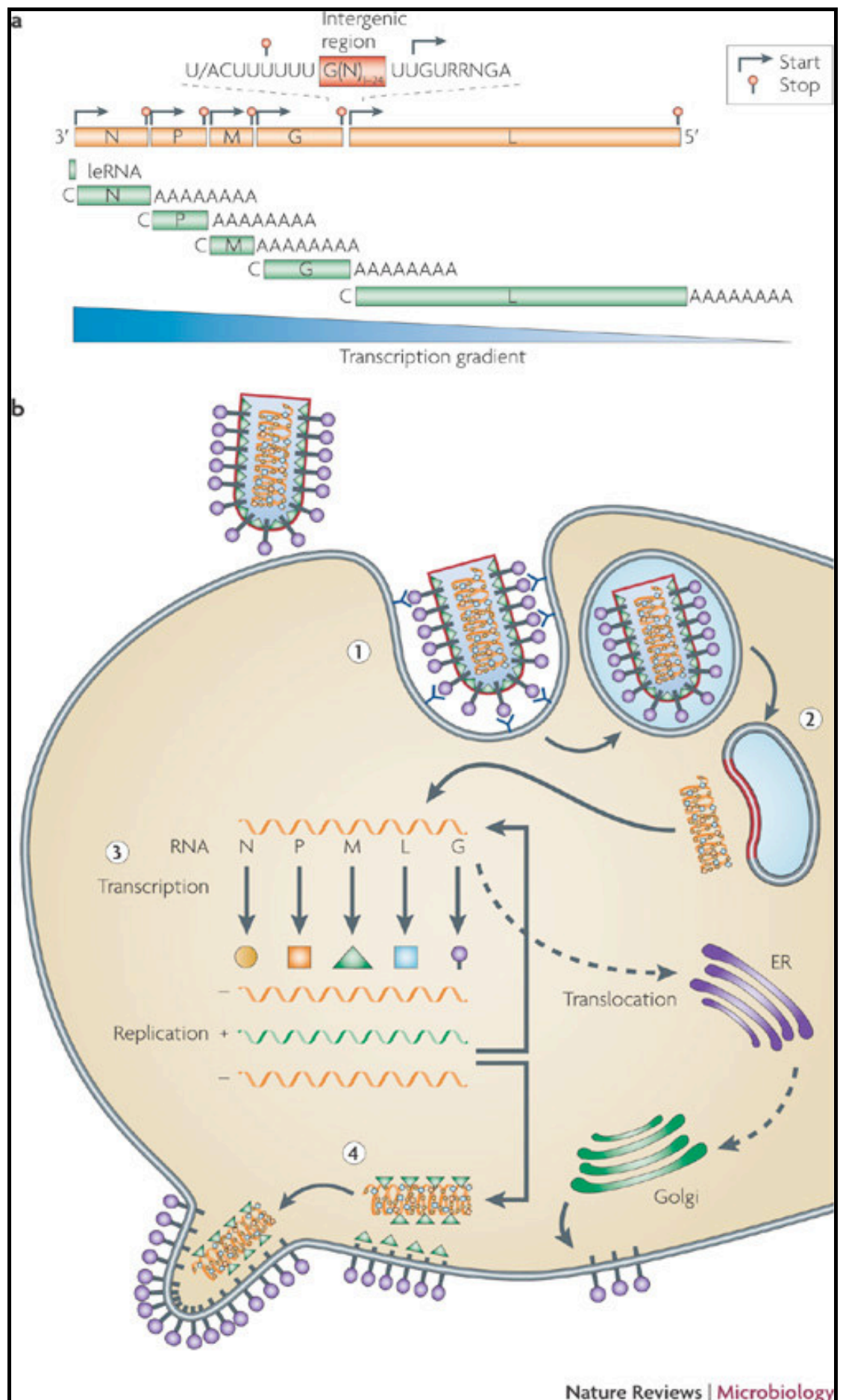

Figura 3. Desenho esquemático do mapa genômico (a) e replicação do Vírus da Raiva (b). Fonte: Schnell et al., 2010. 


\subsection{Os morcegos e o vírus da Raiva}

Os morcegos já tinham sua presença registrada há 50 milhões de anos (Taddei, 1996).

A ordem Chiroptera (cheiros=mão e pteron=asa, animal com mão transformada em asas) subdivide-se em duas subordens (Megachiroptera e Microchiroptera), 17 famílias e aproximadamente 1198 espécies (Nowak, 2003). Os Megachiropteros incluem apenas a família Pteropodidae, os grandes morcegos frugívoros conhecidos como raposas voadoras, que podem atingir até 1,70 m de envergadura. A subordem Microchiroptera inclui 16 famílias (Taddei, 1996).

Espécies das ordens Carnivora e Chiroptera são reconhecidas como reservatórios silvestres (WHO, 2005). Os Lissavírus têm sido detectados nos morcegos em diversos continentes, sendo os morcegos identificados como vetores em dez das onze espécies virais dos Lyssavirus.

As características dos Lyssavirus adaptados a morcegos têm mostrado diferenças quando comparadas à raiva relacionada aos carnívoros, porém somente em 1911, Carini relacionou pela primeira vez a raiva aos morcegos, levantando a hipótese destes serem os transmissores da doença a outros animais, estudando uma epizootia em Santa Catarina, Brasil (Carini, 1911).

Os Desmodus rotundus, chamados de morcegos vampiros (Figura 4), são encontrados do norte do México até a costa norte do Chile, região central da Argentina e costas do Uruguai. Desde o nível do mar até 2 mil metros de altitude (Flores Crespo, 2000). Fósseis descobertos na Flórida e em Cuba indicam que os morcegos vampiros vivem nas Américas desde o período Pleistoceno, 2,5 milhões de anos atrás (Arellano-Sota, 1988).

O hábito alimentar de sangue de vertebrados endotérmicos é conhecido apenas em três espécies de morcegos da região neotropical (América Latina), que compõem a subfamília Desmodondinae, da família Phyllostomidae. Das três espécies conhecidas, D. rotundus, Diaemus youngi e Diphylla ecaudata, a primeira é a mais estudada em razão da sua importância social e econômica, o que ainda não está estabelecido para as outras duas espécies (Brasil, 1996, 2005).

Durante os três primeiros meses de idade, os morcegos hematófagos se alimentam exclusivamente de leite materno, após o que, são introduzidas pequenas quantidades de sangue direto na boca. Entre os cinco e seis meses, o filhote acompanha a mãe para se alimentar, mas provavelmente são amamentados até os nove meses (Lord, 1992). 


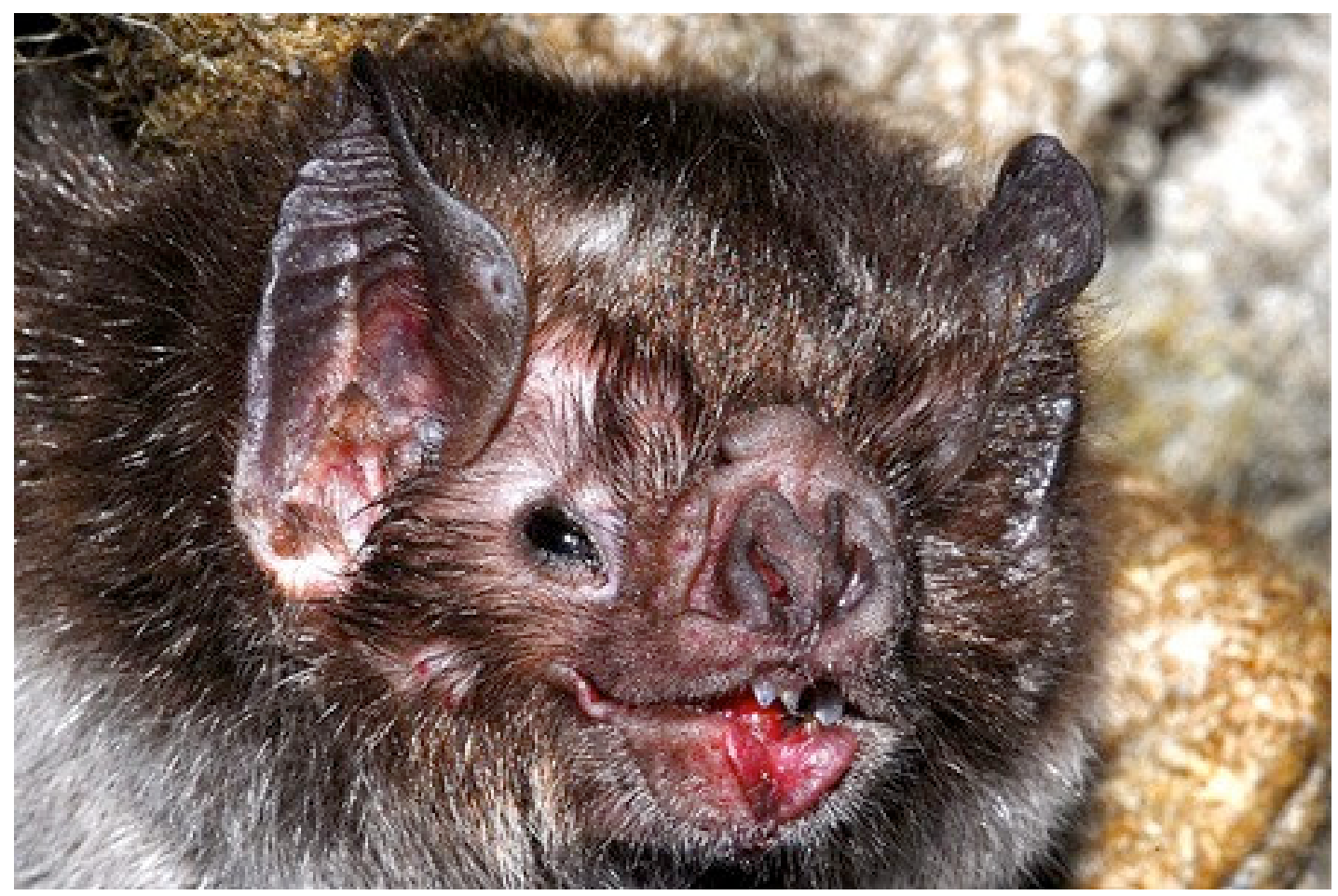

Figura 4. Morcego hematófago Desmodus rotundus.

Fonte: Melo $^{1}[(2010)]$.

Entre os animais silvestres, os morcegos constituem um dos principais reservatórios do vírus da raiva. Nas últimas décadas têm sido frequentes os relatos de morcegos com raiva em vários países do mundo. Segundo relatório da Organização Mundial da Saúde - WHO (WHO, 2005), estima-se que no mundo em torno de 55.000 pessoas, por ano, morrem de raiva. O cão permanece como principal transmissor da raiva para o homem e também como principal vítima da doença, porém nos países que conseguiram controlar a raiva em animais domésticos, o vírus da raiva se mantém circulante na natureza por meio de reservatórios em animais silvestres, demonstrando que a raiva é um problema de saúde pública, podendo ainda acarretar sérios prejuízos ambientais e econômicos, a despeito da existência de vacinas eficazes de uso humano e veterinário (WHO, 1996; PAHO, 1999; WHO, 2005).

Carini (1911) foi o primeiro pesquisador a associar um foco de raiva diagnosticado em animais domésticos à transmissão por morcegos.

Durante a década de 30, ocorreram epidemias em bovinos no Brasil, Colômbia, Bolívia, Venezuela, México e Trinidad. Em Trinidad, a epidemia atingiu 2.000 animais e 53 pessoas. A doença foi inicialmente diagnosticada como botulismo nos animais e poliomielite em humanos, porém Hurst e Pawan $(1931,1932)$ observaram o grande número de mordidas

\footnotetext{
${ }^{1}$ Melo M. [(2010)]. Extraída do site: http://web.me.com/marmello/marcomello/Welcome.html.
} 
de morcegos vampiros em bovinos que, posteriormente, morreram sugerindo que os morcegos eram os responsáveis pela transmissão da doença, o que se confirmou com o isolamento do vírus em numerosos morcegos frugívoros e hematófagos, corroborando assim a hipótese de Carini (1911). Estes estudos estabeleceram as formas de manifestação do vírus da raiva em morcegos como paralítica. Em 1936, Pawan estudou outra epidemia de raiva ocorrida em Trinidad que levou a morte de milhares de bovinos e 89 humanos e isolou, pela primeira vez, o vírus da raiva de um morcego insetívoro (Pawan, 1936).

Alguns pesquisadores relataram também o estado de portador assintomático da doença no qual o animal, quando experimentalmente infectado, podia transmitir continuamente o vírus pela saliva por diversos meses, sem manifestar qualquer anormalidade e sem a ocorrência da forma furiosa de raiva, seguida de recuperação (Hurst e Pawan, 1932; Queiroz Lima, 1934; Torres e Queiroz Lima, 1935, 1936; Pawan, 1936). Entretanto, anos mais tarde Moreno e Baer (1980) não observaram nenhum animal excretando vírus na saliva apenas como portador, nenhum animal que adoecesse e se recuperasse da doença e nenhum animal que excretasse o vírus na saliva e permanecesse saudável. O estado de portador assintomático, que pode ter sido confundido com forma paralítica da raiva, a forma furiosa da doença seguida de recuperação não foram confirmados, porém a ausência de sintomas em morcegos experimentalmente ou naturalmente infectados continuou a ser relatada em morcegos não hematófagos (Sulkin et al., 1959) e morcegos D. rotundus (Setien et al., 1998; Rodrigues e Tamayo, 2000). No Brasil, Silva et al. (1961) isolaram pela primeira vez o vírus da raiva de um morcego não hematófago no Rio de Janeiro em 1957. A partir de então o isolamento deste vírus em várias espécies de morcegos, hematófagos ou não, foi relatado em vários estados brasileiros (Uieda et el., 1996).

A presença do vírus da raiva nas populações de morcegos é difícil de ser determinada sendo que os estudos epidemiológicos, em sua maioria, baseiam-se em relatórios de serviços dos programas de profilaxia da raiva, quando os animais são capturados em razão da queixa ou encaminhados por munícipes. A positividade em estudos desta natureza variou de 3 a $11 \%$ (Richardson et al., 1966; Birney e Rising, 1967; Schowelter, 1980; Steece et al., 1982; Burnett, 1989; Almeida et al., 2003).

Na América Latina, em 1999, foram notificados 95 casos de raiva em morcegos, sendo 22 em hematófagos, 45 em insetívoros e frugívoros e 28 casos, nos quais, o hábito alimentar do animal não foi especificado. Os dados notificados a Organização Panamericana de Saúde (OPAS), entretanto, estão subestimados, o relatório aponta 10 casos de raiva em morcegos ocorridos em 1999 no Brasil enquanto a Coordenação do Programa Estadual da Raiva relatou, 
só para o Estado de São Paulo, 28 casos de raiva em morcegos. De acordo com Belotto et al., (2005), na América Latina, os morcegos são a segunda espécie transmissora da raiva a humanos, apontando 14.7\% de todos os casos humanos estudados entre 1993-2002 e na maioria destes casos os morcegos hematófagos $D$. rotundus estavam envolvidos.

O primeiro estudo com 228 amostras provenientes de 17 países da América Latina e Caribe, pela técnica de anticorpos monoclonais, foi realizado por Diaz et al. (1994) e mostrou que duas variantes estavam amplamente distribuídas na região, a variante mantida por populações de cães e a variante mantida por populações de morcego D. rotundus. Todos os isolados humanos eram de uma dessas duas variantes. Uma amostra de animal doméstico (gato) apresentava a variante de D. rotundus.

Com a utilização do painel de anticorpos monoclonais do CDC-OPAS (Centers for Disease Control and Prevention, Atlanta, Georgia, USA - Organização Panamericana de Saúde), estudos realizados com amostras do Brasil, Argentina e Paraguai, do período de 1987 a 1995 (Delpietro et al., 1997) confirmaram as variantes canina e do morcego hematófago como predominantes: a variante de D. rotundus foi detectada em bovinos, equinos, raposas, morcegos hematófagos e não hematófagos. A variante canina foi detectada em cães, um humano, um búfalo, um bovino e uma lhama. Estes estudos detectaram também as variantes características de morcegos insetívoros, em Tadarida brasiliensis, Lasiurus cinereus e Molossus molossus. Os estudos com amostras do Peru, Colômbia e Venezuela também mostram o predomínio das variantes canina e de D. rotundus (Lopes et al., 1998; Mattos et al., 1996).

O Peru notificou um surto de raiva humana com 29 mortes em 1990, as vítimas relataram história de mordidas de morcegos e a caracterização antigênica da amostra de uma das vítimas revelou padrão idêntico ao de D. rotundus (Lopez et al., 1992). Em 1996 ocorreu outro surto com 9 mortes, e mais duas amostras humanas foram analisadas, indicando variante de morcego hematófago (Warner et al., 1999).

$\mathrm{Na}$ Venezuela, circulam duas variantes relacionadas ao $D$. rotundus. $\mathrm{O}$ sequenciamento genético mostrou que as amostras de morcego vampiro procedentes de uma região específica da Venezuela segregam em um grupo homólogo e outro distinto, mas estreitamente relacionados com as amostras de morcegos vampiros de outros países da América Latina (Mattos et al., 1996).

No Chile, o morcego insetívoro T. brasiliensis é o reservatório do vírus em centros urbanos e fonte de infecção de casos esporádicos reportados em animais domésticos e humanos. A análise de amostras isoladas entre 1977 e 1998 mostrou que nenhuma das 
amostras segregava com amostras relacionadas a reservatórios terrestres (Mattos et al., 2000). O primeiro caso humano registrado no Chile desde 1972 ocorreu em 1996 e a caracterização antigênica e genética indicou o morcego T. brasiliensis como reservatório do vírus (Favi et al., 2002).

No Brasil, entre 1986 e 2000, ocorreram 617 casos de raiva humana, sendo 63 (10,2\%) transmitidos por morcegos. Os dados do Ministério da Saúde (Brasil, 2005) apontam os morcegos como a segunda espécie em número de casos humanos de raiva, lugar anteriormente ocupado pelos felinos domésticos. Infelizmente esses dados não especificam o hábito alimentar do morcego envolvido na transmissão.

O vírus da raiva foi isolado de 41 das 167 espécies de morcegos identificadas no Brasil (Uieda et al., 1996; Castilho et al., 2008; Sodré et al., 2010). Análises de amostras de vírus da raiva isoladas no Brasil confirmaram estudos anteriores de que os reservatórios principais eram os cães e os morcegos vampiros (Ito et al., 2001a; Favoretto et al., 2002).

A variante de morcego hematófago foi detectada em 100\% das amostras de bovinos, equinos, ovinos, suínos, caprinos e morcegos hematófagos e em 58,3\% (35) de 60 amostras de morcegos não hematófagos, pertencentes a 7 das 17 espécies nas quais o vírus foi isolado (Favoretto et al., 2002), indicando que o morcego não hematófago está sendo contaminando com a variante mantida por populações de morcegos hematófagos.

Carrieri et al. (2000) observaram que a raiva em morcegos não hematófagos precede a raiva bovina e em animais de estimação. Se isso se confirmar, os morcegos não hematófagos poderiam ser o elo entre a raiva silvestre e a raiva urbana. Favoretto et al. (2002) detectaram a variante antigênica de $D$. rotundus (AgV3) em amostras isoladas entre 1989 e 2000, em 4 $(30,8 \%)$ das 13 amostras positivas de felinos, em 12 dos 100 cães (12,2\%) e em 3 das 36 amostras obtidas de humanos $(8,3 \%)$. O fato de se detectar a variante 3 em cães e gatos mostra que o papel deste morcego no ciclo da raiva não está limitado a raiva silvestre.

No período de 1989 a 1993, o sequenciamento genético de amostras de vírus da raiva de diferentes espécies animais relacionou a maioria destes isolados com a variante mantida por populações de cães. Porém, duas amostras de bovinos isoladas em 1991 e 1993 foram caracterizadas como mantidas por populações de morcego D. rotundus. Este dado demonstra que naquele momento já havia duas variantes circulantes, a variante canina predominante e a variante de morcego hematófago (Martorelli et al., 2001). Amostras isoladas de equinos, bovinos e outros animais de rebanho foram analisadas no período de 1996 a 2000 e caracterizadas antigênicamente como variante mantida por populações de morcego $D$. rotundus (Favoretto et al., 2002). 
No Brasil, até o ano de 2003, o ciclo epidemiológico de transmissão responsável pelos casos de raiva humana foi o relacionado à cães e gatos, com 72,5\% dos casos. A ocorrência de dois surtos de raiva humana transmitido por morcegos, ocorridos nos municípios de PortelPará (15 casos) e Viseu-Pará (6 casos), em 2004 somado à diminuição da raiva em cães, inverteu o panorama epidemiológico da raiva e o morcego tornou-se o principal responsável pelos casos de raiva humana. Essa situação manteve-se no ano de 2005, devido os surtos por morcegos hematófagos no Pará e Maranhão, tendo sido notificado 29 casos transmitidos por morcegos, um por cão e um por primata (da Rosa et al., 2006; Brasil, 2005). Em outubro de 2005 foi notificado um novo foco de raiva humana transmitida por morcego hematófago no Maranhão (Brasil, 2005).

Segundo dados do Ministério da Saúde do Brasil 13 casos foram confirmados e 12 foram a óbito entre 2006 e 2008. Em 2009 foi reportado o primeiro caso de cura de raiva no Brasil, de um paciente com histórico de contato e agressão por morcego hematófago, com confirmação clínica e laboratorial de raiva em 2008, com a administração do Protocolo de Recife, uma adaptação do Protocolo de Milwaukee (Brasil, 2009; Willoughby et al., 2005).

A raiva transmitida por morcegos hematófagos tem exigido maior atenção epidemiológica representando um novo desafio para o controle da doença. Não é uma forma de transmissão nova, porém desde 2004 têm-se observado o aumento no número de casos, requerendo novas estratégias de controle, mais complexas que as utilizadas nos programas de profilaxia da raiva dirigidas ao controle de variantes relacionadas ao ciclo terrestre de transmissão (Schneider et al., 2004).

Faber et al. (2004), mapearam o genoma completo de um Lasyonicteris noctivagans, importante reservatório do vírus na América do Norte. Recentemente, em virtude da importância de se conhecer mais a respeito dos vírus, foram mapeados os genomas de outras variantes do vírus da raiva, uma isolada de T. brasiliensis, reservatório deste vírus no Chile, de um Procyon lotor, importante reservatório no Canadá, de uma raposa Dusicyon sp. um dos reservatórios do vírus no Brasil (Delmas et al., 2008; Szanto et al., 2008; Mochizuki et al., 2009). Apenas recentemente, um grupo japonês em fevereiro de 2011, sequenciou o vírus da raiva de um morcego hematófago $D$. rotundus e um morcego frugívoro Artibeus lituratus do Brasil, entretanto as sequências não se encontram disponível no banco de dados GenBank (Mochizuki et al., 2011).

A escassez de dados, na literatura, a respeito do genoma completo da variante mantida por populações de morcegos hematófagos $D$. rotundus, deixa uma lacuna no entendimento da epidemiologia molecular deste vírus. Este fato confirma a necessidade do desenvolvimento de 
metodologias que permitam estudos complementares mais precisos a respeito da biologia e epidemiologia da raiva em quirópteros, com o sequenciamento completo de isolados de morcego $D$. rotundus com a finalidade de desenvolver estudos genéticos evolutivos além da genotipagem, sendo fundamental para o melhor entendimento da diversidade genética desse vírus em diferentes hospedeiros sendo que a importância epidemiológica desta espécie na transmissão da raiva é inquestionável. 


\section{OBJETIVOS}

\subsection{Geral}

Desenvolver estudo genético da variante do vírus da raiva mantida por populações de morcego D. rotundus, isolada de uma amostra deste morcego no Brasil.

\subsection{Específicos}

a) Estabelecer um protocolo rápido e econômico de síntese de cDNA (RT-PCR) para o vírus da raiva independente da técnica de clonagem;

b) Desenhar primers específicos e eficientes para o sequenciamento da variante do vírus da raiva estudada;

c) Comparar filogeneticamente as amostras da variante mantida por morcegos hematófagos $D$. rotundus com a amostra padrão da espécie viral Rabies virus, além de outras desta mesma espécie viral disponíveis no GenBank.

d) Estabelecer possíveis padrões genéticos de diferenciação com a amostra de referência da espécie viral Rabies virus, de acordo com a região do genoma identificada. 


\section{MATERIAL E MÉTODOS}

Todos os procedimentos foram realizados no laboratório NB3 do Instituto de Ciências Biomédicas da Universidade de São Paulo - SP, segundo as normas de biosegurança vigentes.

Cada uma das etapas foi realizada em diferentes espaços físicos, sendo uma área destinada à extração do ácido nucléico, outra para a reação de PCR e a terceira somente para manipulação do produto amplificado. Cuidados para evitar contaminação por manipulações técnicas como pipetagens, uso de ponteiras com filtros e fluxos laminares para as etapas de PCR, também foram utilizados, como é de rotina destes laboratórios.

\subsection{Amostras}

Para execução deste trabalho, foi selecionada a amostra de vírus da raiva isolada de morcego hematófago $D$. rotundus na região tropical e temperada das Américas: amostra IBDR341/2001 isolada de morcego hematófago D. rotundus na cidade de São José do Barreiro, estado de São Paulo, Brasil no ano de 2001, gentilmente cedida pela Dr $^{\mathrm{a}}$ Elenice Maria Sequetin Cunha.

A amostra de vírus pertence e tem sido mantida a $-70{ }^{\circ} \mathrm{C}$ no banco de amostras do Laboratório de Raiva e Encefalites do Centro de P\&D de Sanidade Animal do Instituto Biológico da Agência Paulista de Tecnologia dos Agronegócios da Secretaria da Agricultura do Estado de São Paulo, em tecido nervoso central com título de $10^{-5} \mathrm{DL}_{50}$ quinta passagem em cérebro de camundongo albino suíços sob responsabilidade da $\operatorname{Dr}^{\mathrm{a}}$ Elenice Maria Sequetin Cunha. Para este estudo foi registrada sob o número brdrusp100/07 no banco de amostras do Núcleo de Pesquisas em Raiva do Laboratório de Virologia Clínica e Molecular do Instituto de Ciências Biomédicas do Departamento de Microbiologia da Universidade de São Paulo (ICBII-USP).

Uma amostra isolada de um bovino positivo para raiva foi utilizada para os testes de padronização e também como controle positivo. Esta amostra foi encaminhada para o Núcleo de Pesquisas em Raiva do Laboratório de Virologia Clínica e Molecular do Instituto de Ciências Biomédicas da Universidade de São Paulo (ICBII-USP) com a finalidade de caracterização antigênica, e foi registrada no banco de amostras de vírus da raiva sob identificação brbvusp01/06, procedente da cidade de Manoel Emídio-Piauí. 


\subsection{Imunofluorescência Indireta}

Para a caracterização da variante antigênica foi realizado o teste de Imunofluorescencia Indireta utilizando um painel formado por oito anticorpos monoclonais contra o nucleocapsídeo do vírus da raiva, produzido pelo Centers for Disease Control and Prevention-CDC, Atlanta, Georgia, USA e distribuído pela Organização Pan-americana da Saúde - OPAS, pré-estabelecido para a tipificação do vírus da raiva isolado em amostras das Américas (PAHO, 2000). Cada amostra foi processada com o painel de anticorpos monoclonais por duas vezes e em lotes e dias diferentes.

\subsection{Cultivo Celular}

A amostra brdrusp100/07 foi cultivada em sistema de cultura celular para manutenção e aumento de volume. Paralelamente ao cultivo, os testes moleculares foram padronizados com a amostra brbvusp01/06.

A linhagem celular escolhida foi BHK-21 (Baby Hamster Kidney) já bastante descrita na literatura e amplamente utilizada em estudos com vírus da raiva em virtude da sua sensibilidade ao vírus, de acordo com o seguinte protocolo de cultivo.

O meio de crescimento EMEM (Eagle's Minimum Essential Medium) foi suplementado com vitaminas (2X), glutamina (2X) e 10\% de Soro Fetal Bovino (SFB), além de $100 \mathrm{U} / \mathrm{mL}$ de penicilina, $100 \mu \mathrm{g} / \mathrm{mL}$ de estreptomicina e $0,25 \mu \mathrm{g} / \mathrm{mL}$ de anfotericina $\mathrm{B}$.

Uma suspensão de $20 \%$ do material (cérebro, cerebelo e hipocampo) foi preparada para a inoculação no sistema de cultivo celular. Após centrifugação a 500 g por 10 minutos, $0,5 \mathrm{~mL}$ do sobrenadante foi adicionado à suspensão $2 \times 10^{6}$ células BHK-21 em 1,5 mL de EMEM. As células e vírus foram incubados por $1 \mathrm{~h}$ a $37^{\circ} \mathrm{C}$, agitando a cada 15 minutos, para adsorção do vírus às células e a suspensão foi centrifugada por 5 minutos a $100 \mathrm{~g}$.

O sobrenadante foi descartado e as células ressuspendidas em $10 \mathrm{~mL}$ de EMEM com $10 \%$ de soro fetal bovino. O teste de imunofluorescência direta foi realizado, para confirmar a presença do vírus da raiva, com $4 \mathrm{~mL}$ do material cultivado fixado em acetona resfriada a -20 ${ }^{\circ} \mathrm{C}$, (Goldwasser e Kissiling, 1958; Dean et al., 1996) empregando-se conjugado anti-vírus da raiva (Chemicon International, Light Diagnostics Rabies DFA Reagent - Monoclonal antibody FITC-conjugate) adquirido comercialmente.

Os $6 \mathrm{~mL}$ restantes foram inoculados em garrafa de $25 \mathrm{~cm}^{3}$, que pode ser mantida em um sistema fechado ou incubada a $37{ }^{\circ} \mathrm{C}$ em atmosfera de $5 \%$ de $\mathrm{CO}_{2}$ durante 40 a 48 horas e 
novamente foi realizado o teste de Imunofluorescência Direta para confirmar a presença do vírus e preparado o subcultivo. Após a lavagem da monocamada por 2 vezes com $5 \mathrm{~mL}$ de PBS (livre de $\mathrm{Mg}^{++}$e $\mathrm{Ca}^{++}$), foi adicionado $2 \mathrm{~mL}$ Tripsina-EDTA e incubado em temperatura ambiente por aproximadamente 5 minutos. As células foram então ressuspendidas em meio EMEM e dispersas por pipetagem vigorosa (cerca de 10 a 20 vezes). O volume de $3 \mathrm{~mL}$ da suspensão de células foram ressuspendidos em $3 \mathrm{~mL}$ de meio EMEM, incubados a $37^{\circ} \mathrm{C}$ por 2-3 dias.

Após este período foi realizado teste de Imunofluorescência Direta em uma alíquota para confirmar a presença do vírus e o lote de vírus produzido foi armazenado em freezer -70 ${ }^{\circ} \mathrm{C}$ até o momento do uso.

\subsection{Descrição dos Oligonucleotídeos Iniciadores (primers)}

Para amplificar e sequenciar todo o genoma viral da variante do vírus da raiva isolada de morcego hematófago $D$. rotundus foram desenhados oligonucleotídeos com o programa OLIGO 6.83 (Molecular Biology Insights, Inc., Cascade, CO, Estados Unidos), gentilmente cedido pelo Prof. Dr. Paolo Marinho de Andrade Zanotto. A análise da qualidade dos mesmos, em relação à temperatura de anelamento, presença de regiões de falso pareamento e presença de 'hairpins' também foi feita com o mesmo programa e os oligonucleotídeos foram sintetizados pela Invitrogen Brazil Custom Primers.

\subsection{Extração do RNA Total}

Todo o processo de extração foi realizado em banho de gelo (amostras e reagentes) e utilizando centrifuga refrigerada. Ao lisado de células $(1 \mathrm{~mL})$ foram adicionados $200 \mu \mathrm{L}$ de fenol:clorofórmio:álcool isoamílico 25:24:1 (Invitrogen Corporation, Carlsbad, CA, Estados Unidos). A mistura resultante foi homogeneizada em vórtex por 15 segundos, incubada em banho de gelo por 5 minutos e centrifugada a $12.000 \mathrm{~g}, 4^{\circ} \mathrm{C}$, por 15 minutos.

Após centrifugação, o sobrenadante (cerca de $400 \mu \mathrm{L}$ ) foi transferido para um tubo estéril, sendo o RNA precipitado pela adição de isopropanol (Sigma-Aldrich Co. St. Louis, MO, Estados Unidos) volume a volume, seguido de homogeneização em agitador e incubação em banho de gelo por 15 minutos. A mistura foi novamente centrifugada a $12.000 \mathrm{~g}$, por 15 minutos. A seguir o sobrenadante foi desprezado e o sedimento lavado com $1 \mathrm{~mL}$ de etanol a $75 \%$ (Merck, Darmstadt, Alemanha) diluído em $\mathrm{H}_{2} \mathrm{O}$ DEPC $^{\circledR}$ (Invitrogen Corporation, 
Carlsbad, CA, Estados Unidos). A suspensão foi então centrifugada a $7.500 \mathrm{~g}$, a $4{ }^{\circ} \mathrm{C}$ por 8 minutos. O sobrenadante foi novamente descartado e o sedimento, após secagem, foi ressuspendido em $30 \mu \mathrm{L}$ de $\mathrm{H}_{2} \mathrm{O}$ DEPC ${ }^{\circledR}$ (Invitrogen Corporation, Carlsbad, CA, Estados Unidos), contendo $40 \mathrm{U}$ de Inibidor de Ribonuclease (RNAse OUT ${ }^{\circledR}$ - Invitrogen Corporation, Carlsbad, CA, Estados Unidos). A quantificação do RNA foi realizada com o equipamento Thermo Scientific NanoDrop ${ }^{\mathrm{TM}} 1000$ Spectrophotometer $_{\text {Thermo }}$ (Thermo Fisher Scientific Inc., Waltham, MA, Estados Unidos), integrante do parque de equipamentos do Prof. Dr. Paolo Marinho de Andrade Zanotto.

\subsection{Reação em cadeia pela polimerase precedida de transcrição (RT-PCR)}

\subsubsection{Transcrição Reversa (RT-PCR)}

A reação de transcrição reversa (RT-PCR), para a obtenção de cDNA, foi realizada em uma única fase utilizando o sistema Super Script ${ }^{T M}$ II Invitrogen ${ }^{\circledR}$ (Invitrogen Corporation, Carlsbad, CA, Estados Unidos). Nesta fase, $4 \mu \mathrm{L}$ de RNA total extraído foram acrescidos a um mix contendo $200 \mathrm{U}$ de Transcriptase Reversa (RT) (MMLV - Moloney-murine leukemia virus/Super Script ${ }^{T M}$ Invitrogen $^{\circledR}$ - Invitrogen Corporation, Carlsbad, CA, Estados Unidos) diluídas no tampão da enzima (50 mM de tris- $\mathrm{HCl}(\mathrm{pH}-8,3), 75 \mathrm{mM}$ de $\mathrm{KCl}, 3 \mathrm{mM} \mathrm{MgCl} 2)$, $4 \mathrm{mM}$ de DTT, 1,2 mM de cada dNTP (dATP, dGTP, dTTP, dCTP/Gibco-BRL ${ }^{\circledR}$ - Invitrogen Corporation, Carlsbad, CA, Estados Unidos), $2 \mu \mathrm{M}$ de cada primer (polaridade positiva e negativa), $40 \mathrm{U}$ de Inibidor de Ribonuclease (RNAse OUT ${ }^{\circledR}$ - Invitrogen Corporation, Carlsbad, CA, Estados Unidos), e $\mathrm{H}_{2} \mathrm{O}$ DEPC $^{\circledR}$ (Invitrogen Corporation, Carlsbad, CA, Estados Unidos), perfazendo um volume final de $25 \mu \mathrm{L}$. A transcrição foi realizada a $42{ }^{\circ} \mathrm{C}$ por uma hora. O cDNA foi utilizado para a amplificação e posteriormente armazenado a $70{ }^{\circ} \mathrm{C}$.

Paralelamente foi realizada, com o auxílio do High Capacity cDNA Archive kit $^{\circledR}$ (Applied Biosystems, Foster City, CA, Estados Unidos), outra transcrição reversa para gerar cDNA randômico, onde $50 \mu \mathrm{L}$ de RNA extraído foram diluídos em mix contendo $10 \mu \mathrm{L}$ de Random primers 10X, $10 \mu \mathrm{L}$ tampão da RT 10X, $250 \mathrm{U}$ de MultiScribe RT enzyme, $4 \mu \mathrm{L}$ de dNTP mix [100mM], 1 U de inibidor de Ribonuclease (RNAse OUT ${ }^{\circledR}$ - Invitrogen Corporation, Carlsbad, CA, Estados Unidos) e água DEPC ${ }^{\circledR}$ (Invitrogen Corporation, Carlsbad, CA, Estados Unidos) para completar o volume de $100 \mu \mathrm{L}$. A mistura foi incubada a $25{ }^{\circ} \mathrm{C}$ por 10 minutos e $37^{\circ} \mathrm{C}$ por 120 minutos no termociclador MasterCycler personal 
Eppendorf $^{\circledR}$ (Eppendorf AG, Hamburg, Alemanha). O cDNA foi utilizado para a amplificação e posteriormente armazenado a $-70^{\circ} \mathrm{C}$.

Uma metodologia diferenciada para a síntese de $c D N A$ longo foi desenvolvida por Campos et al. (trabalho em fase de publicação) ${ }^{2}$ a partir da metodologia para síntese de cDNA em HIV (Rousseau et al., 2006). Os resultados obtidos com a utilização desta metodologia foram testados para a amplificação da nucleoproteína, fosfoproteína, proteína de matriz, glicoproteína e polimerase viral. Esta nova metodologia encontra-se em fase final de análise pelos relatores da revista Journal of Virological Methods e está descrita a seguir.

Ao RNA extraído, cerca de $25 \mu \mathrm{L}$, foi combinado com $2 \mu \mathrm{L}$ de $10 \mathrm{mM}$ de dNTP (Invitrogen Corporation, Carlsbad, CA, Estados Unidos) e $5 \mu \mathrm{L}$ do primer anti-sense (reverse) a uma concentração de $10 \mathrm{pmol} / \mu \mathrm{L}$, na posição final do genoma (extremidade 5') e incubados a $65{ }^{\circ} \mathrm{C}$ por 5 minutos. Em seguida, a uma temperatura de $45{ }^{\circ} \mathrm{C}$, foram adicionados $19 \mu \mathrm{L}$ da segunda mistura contendo $200 \mathrm{U}$ de Transcriptase Reversa (RT) (MMLV - Moloney-murine leukemia virus/SuperScript ${ }^{T M}$ Invitrogen $^{\circledR}$ - Invitrogen Corporation, Carlsbad, CA, Estados Unidos) diluídas no tampão da enzima (50 mM de tris$\mathrm{HCl}$ (pH-8,3), $75 \mathrm{mM}$ de $\mathrm{KCl}, 3 \mathrm{mM} \mathrm{MgCl}_{2}$ ), $4 \mathrm{mM}$ de DTT, $40 \mathrm{U}$ de Inibidor de Ribonuclease (RNAse OUT ${ }^{\circledR}$ - Invitrogen Corporation, Carlsbad, CA, Estados Unidos), e $\mathrm{H}_{2} \mathrm{O}$ DEPC ${ }^{\circledR}$ (Invitrogen Corporation, Carlsbad, CA, Estados Unidos), perfazendo um volume final de $51 \mu \mathrm{L}$. A primeira etapa da transcrição foi realizada a $45^{\circ} \mathrm{C}$ por uma hora e meia. A seguir foram adicionados mais $200 \mathrm{U}$ de Transcriptase Reversa (RT) (MMLV - Moloneymurine leukemia virus/SuperScript ${ }^{T M}$ Invitrogen $^{\circledR}$ - Invitrogen Corporation, Carlsbad, CA, Estados Unidos) e a reação incubada por mais uma hora e meia, sendo posteriormente inativada a $70{ }^{\circ} \mathrm{C}$ durante 15 minutos, seguido de um ciclo de $37^{\circ} \mathrm{C}$ por 20 minutos.

Após a síntese o cDNA foi quantificado com o equipamento Thermo Scientific NanoDrop $^{\mathrm{TM}} 1000$ Spectrophotometer $_{\text {Thermo }}$ (Thermo Fisher Scientific Inc., Waltham, MA, Estados Unidos) ou com o uso do padrão de massa molecular Low DNA Mass Ladder ${ }^{\circledR}$ (Invitrogen Corporation, Carlsbad, CA, Estados Unidos).

Foi realizada a amplificação parcial do gene $\mathrm{N}(765 \mathrm{pb})$ para a confirmação da viabilidade do cDNA "longo".

Também foi testada a metodologia de síntese do cDNA com o cMaster $^{T M}$ RT kit (Eppendorf AG, Hamburg, Alemanha) seguindo instruções do frabricante.

\footnotetext{
2 Campos et al. One-step protocol for amplification of full-length cDNA of the rabies virus genome. A ser publicado na Journal of Virological Methods; 2011.
} 


\subsubsection{Amplificação (PCR)}

Partindo da temperatura já estabelecida para os testes de amplificação parcial do gene N, já utilizados no Laboratório de Virologia Clínica e Molecular, foram testadas todas as combinações possíveis com a utilização dos primers desenhados e diferentes temperaturas de anelamento dos oligonucleotídeos (gradiente).

Para a reação de PCR, com os primers desenhados para cada uma das regiões alvo selecionadas, foram utilizados $50 \mathrm{ng}$ de cDNA diluídos em tampão de reação $10 \mathrm{mM}$ tris- $\mathrm{HCl}$ (pH 9.0), $50 \mathrm{mM}$ de $\mathrm{KCl}$ (PCR buffer 10X - Invitrogen Corporation, Carlsbad, CA, Estados Unidos), 2,5 $\mathrm{mM} \mathrm{MgCl} 2,200 \mu \mathrm{M}$ de cada dNTP, $1 \mu \mathrm{M}$ de cada primer (polaridade positiva e

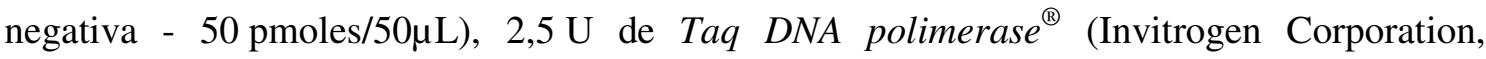
Carlsbad, CA, Estados Unidos) e $\mathrm{H}_{2} \mathrm{O}$ DEPC $^{\circledR}$ (Invitrogen Corporation, Carlsbad, CA, Estados Unidos) para completar um volume final de $50 \mu \mathrm{L}$.

Tabela 1 - Descrição dos primers utilizados nas reações de RT/PCR e Sequenciamento para a nucleoproteína.

\begin{tabular}{lcccc}
\hline \multicolumn{1}{c}{ Utilização } & $\begin{array}{c}\text { Primer } \\
\left(5^{\prime} \rightarrow 3^{\prime}\right)\end{array}$ & $\begin{array}{c}\text { Posição } \\
(\text { nucleotídeo }-\mathbf{n t})\end{array}$ & Sequência & Referência \\
\hline $\begin{array}{l}\text { RT/PCR e } \\
\text { Sequenciamento }\end{array}$ & Foward & $55-75$ & ATG TAA CAC CTC TAC AATG & Smith et al., 1995 \\
$\begin{array}{l}\text { RT/PCR e } \\
\text { Sequenciamento }\end{array}$ & $\begin{array}{l}\text { Reverse } \\
\text { RT/PCR e }\end{array}$ & $1533-1514$ & TTG ACG AAG ATC TTG CTC AT & Smith et al., 1995 \\
Sequenciamento & Reverse & $869-849$ & CCT CAA AGT TCT TGT GGA AGA & Soares et al., 2002 \\
\hline
\end{tabular}

Somente para amplificar e sequenciar a nucleoproteína foram também utilizados iniciadores complementares ao gene $\mathrm{N}$ da nucleoproteína, descritos na literatura (Smith et al., 1995; Soares et al., 2002). A descrição dos primers, bem como a localização dos mesmos, estão ilustradas na tabela 1 .

As amplificações foram realizadas no termociclador MasterCycler Gradient Eppendorf ${ }^{\circledR}$ (Eppendorf AG, Hamburg, Alemanha), com preaquecimento a $95^{\circ} \mathrm{C}$ por 5 minutos, para denaturação, seguidos de 35 ciclos, cada um deles composto de 45 segundos a $94{ }^{\circ} \mathrm{C}$ para denaturação do DNA molde, 45 segundos a $55^{\circ} \mathrm{C}$ para emparelhamento dos 
primers e 90 segundos a $72{ }^{\circ} \mathrm{C}$ para a extensão das novas cadeias. Ao final dos 35 ciclos, seguiu-se um aquecimento a $72^{\circ} \mathrm{C}$ por 5 minutos de extensão final.

Para a reação de PCR da polimerase viral, com o intuito de amplificar completamente o gene L, mais de 6.000 nt (6.476 nt para a amostra de referência NC_001542) e do genoma completo (11.932 nt para a amostra PV) foi utilizado o kit Expand Long Template PCR System $^{\circledR}$ (Roche Diagnostics GmbH, Mannheim, Alemanha). Também foram necessários inúmeros testes com fragmentos menores utilizando primers internos (Tabela 2).

As amplificações e sequenciamento da polimerase viral, com a combinação de iniciadores desenhados, foram realizadas com 25ng de cDNA diluídos em tampão de reação $10 \mathrm{mM}$ tris- $\mathrm{HCl}$ (pH 9.0), $50 \mathrm{mM}$ de $\mathrm{KCl}$ (PCR buffer 10x - Invitrogen Corporation, Carlsbad, CA, Estados Unidos), 2,5 mM $\mathrm{MgCl}_{2}, 200 \mu \mathrm{M}$ de cada dNTP (Invitrogen Corporation, Carlsbad, CA, Estados Unidos), $1 \mu \mathrm{M}$ de cada primer (polaridade positiva ou negativa), 2,5 U de Taq DNA polimerase ${ }^{\circledR}$ (Invitrogen Corporation, Carlsbad, CA, Estados Unidos) e $\mathrm{H}_{2} \mathrm{O}$ DEPC $^{\circledR}$ (Invitrogen Corporation, Carlsbad, CA, Estados Unidos) para completar um volume final de $50 \mu \mathrm{L}$.

A amplificação dos fragmentos longos foi realizada no termociclador MasterCycler Gradient Eppendorf ${ }^{\circledR}$ (Eppendorf AG, Hamburg, Alemanha), com preaquecimento a $95^{\circ} \mathrm{C}$ por 5 minutos para denaturação, seguidos de um touchdown de duas rodadas de 10 ciclos e uma rodada de 20 ciclos, totalizando 40 ciclos, o primeiro conjunto de ciclos foi composto de 45 segundos a $94^{\circ} \mathrm{C}$ para denaturação do DNA molde, 45 segundos a $57^{\circ} \mathrm{C}$ para emparelhamento dos primers e 150 segundos a $72{ }^{\circ} \mathrm{C}$ para a extensão das novas cadeias, o segundo conjunto composto de 45 segundos a $94{ }^{\circ} \mathrm{C}$ para denaturação do DNA molde, 45 segundos a $56^{\circ} \mathrm{C}$ para emparelhamento dos primers e 150 segundos a $72{ }^{\circ} \mathrm{C}$ para a extensão das novas cadeias e o terceiro conjunto composto de 45 segundos a $94{ }^{\circ} \mathrm{C}$ para denaturação do DNA molde, 45 segundos a $55^{\circ} \mathrm{C}$ para emparelhamento dos primers e 150 segundos a $72^{\circ} \mathrm{C}$ para a extensão das novas cadeias. Ao final dos 40 ciclos, seguiu-se um aquecimento a $72{ }^{\circ} \mathrm{C}$ por 5 minutos de extensão final.

\subsection{Detecção por Eletroforese dos Produtos Amplificados}

Os produtos amplificados foram analisados por eletroforese em gel de agarose (Invitrogen Corporation, Carlsbad, CA, Estados Unidos) a 1,5\% em tampão TBE 1x (89 mM tris $\mathrm{HCl} ; 89 \mathrm{mM} \mathrm{H}_{3} \mathrm{BO}_{3} ; 2$ mM Na 2 EDTA, pH 8,3 - Invitrogen Corporation, Carlsbad, CA, Estados Unidos) e 0,5 $\mu \mathrm{g} / \mathrm{mL}$ de brometo de etídio (Edt Br-Sigma-Aldrich Co. St. Louis, MO, 
Estados Unidos). Uma mistura de $10 \mu \mathrm{L}$ de produto amplificado e $2 \mu \mathrm{L}$ de azul de bromofenol (loading buffer) foi aplicada no gel de agarose submetido então à eletroforese, em cuba horizontal, em tampão TBE 1x (Invitrogen Corporation, Carlsbad, CA, Estados Unidos) durante 45 minutos a 100 volts. A visualização do gel foi realizada sobre transluminador de luz ultravioleta (UV), sendo os resultados comparados aos controles positivos, negativos e aos marcadores de peso molecular $\left(1 \mathrm{~Kb}\right.$, Fermentas ${ }^{\circledR}$ International Inc., Burlington, Ontario, Canadá), sendo a seguir fotodocumentados.

\subsection{Purificação da Reação de Amplificação}

Para produtos amplificados que apresentaram fragmentos inespecíficos menores que 300 pb foi utilizado o sistema de colunas PureLink ${ }^{T M}$ PCR Purification Kit ${ }^{\circledR}$ (Invitrogen Corporation, Carlsbad, CA, Estados Unidos), para purificação diretamente do produto de PCR, seguindo as instruções do fabricante. Para produtos amplificados que apresentaram fragmentos inespecíficos com mais de 300 pb foi utilizado o PureLink ${ }^{T M}$ Quick Gel Extraction $\mathrm{Kit}^{\circledR}$ (Invitrogen Corporation, Carlsbad, CA, Estados Unidos) a partir da excisão do fragmento do gel de agarose, seguindo as instruções do fabricante. Para alguns produtos do gene L, com apenas o fragmento de interesse, foi necessária a purificação do produto de PCR, sendo utilizado o sistema ExoSAP-IT ${ }^{\circledR}$ (GE Healthcare Bio-Sciences Ltd - USB Corporation, Cleveland, $\mathrm{OH}$, Estados Unidos) segundo instruções do fabricante (adicionando $16 \mu \mathrm{L}$ do kit a $40 \mu \mathrm{L}$ de produto de PCR e incubados por 15 minutos a $37^{\circ} \mathrm{C}$ e 15 minutos a $80^{\circ} \mathrm{C}$ ).

\subsection{Reação de Sequenciamento}

Após a amplificação, as fitas de DNA foram submetidas à reação de sequenciamento utilizando o kit comercial BigDye ${ }^{T M}$ terminator - cycle sequencing read reaction - Applied Biosystems $^{\circledR}$ (Applied Biosystems, Foster City, CA, Estados Unidos), seguindo as instruções do fabricante, com os primers previamente sintetizados para mapear os genes codificadores para as proteínas $\mathrm{N}, \mathrm{P}, \mathrm{M}$ e $\mathrm{G}$.

Em um microtubo contendo cerca de 10-30 ng de produto de PCR, foram adicionados a um microtubo acrescido de $2 \mu \mathrm{L}$ de Tampão Save Money 5X (Tris HCl 200 mM pH 9,0 e $5 \mathrm{mM} \mathrm{MgCl}_{2}$ ), $3.2 \mathrm{pMol} / \mu \mathrm{L}$ do primer, $2 \mu \mathrm{L}$ do kit ABI PRISM Dye ${ }^{\text {TM }}$ Terminator Cycle Sequencing Ready Reaction kit (Big Dye v3.1 ${ }^{\circledR}$ Applied Biosystems, Foster City, CA, Estados Unidos) e água DEPC $^{\circledR}$ (Invitrogen Corporation, Carlsbad, CA, Estados Unidos) para 
completar um volume final de $10 \mu \mathrm{L}$. Este procedimento foi efetuado separadamente para cada um dos primers.

Para a polimerase foram necessários cerca de 60-100 ng de produto de PCR purificado. A quantificação do DNA foi realizada no Thermo Scientific NanoDrop ${ }^{\mathrm{TM}} 1000$ Spectrophotometer $_{\text {Thermo }}$ (Thermo Fisher Scientific Inc., Waltham, MA, Estados Unidos) ou com o padrão de massa molecular Low DNA Mass Ladder ${ }^{\circledR}$ (Invitrogen Corporation, Carlsbad, CA, Estados Unidos).

A mistura homogeneizada foi levada ao termociclador MasterCycler Gradient Eppendorf ${ }^{\circledR}$ (Eppendorf AG, Hamburg, Alemanha), pré-aquecido a $96^{\circ} \mathrm{C}$ por 5 minutos, para denaturação da fita de DNA, seguido de 25 ciclos, cada um deles composto de 10 segundos a $96{ }^{\circ} \mathrm{C}$ para denaturação do DNA molde, 15 segundos a $50{ }^{\circ} \mathrm{C}$ para emparelhamento dos primers e 4 minutos a $60{ }^{\circ} \mathrm{C}$ para extensão da nova fita de DNA.

\subsubsection{Purificação da reação de sequenciamento}

O produto obtido foi purificado, visando a remoção de excesso de dideoxinucleotídeos “terminadores" presentes na reação, por precipitação com isopropanol, descrita a seguir:

Ao produto da reação de sequenciamento foram adicionados $30 \mu \mathrm{L}$ de água $\mathrm{DEPC}^{\circledR}$ (Invitrogen Corporation, Carlsbad, CA, Estados Unidos) e $60 \mu \mathrm{L}$ de isopropanol a 100\%, com agitação e centrifugação por 60 minutos a $4.000 \mathrm{~g}$ em temperatura ambiente, utilizando centrífuga (Centrifuge 5804R - Eppendorf AG, Hamburg, Alemanha). O sobrenadante foi descartado e em seguida foi adicionado $250 \mu \mathrm{L}$ de etanol $70 \%$, com agitação e nova centrifugação por 30 minutos a $4000 \mathrm{~g}$ em temperatura ambiente.

As amostras purificadas e precipitadas foram ressuspendidas com $10 \mu \mathrm{L}$ de formamida ultra pura (formamida Hi-Di ${ }^{\circledR}$ - Applied Biosystems, Foster City, CA, Estados Unidos), denaturadas a $95{ }^{\circ} \mathrm{C}$ por 3 minutos e resfriadas em banho de gelo por mais 2 minutos e então submetidas à eletroforese em polímero POP6 ${ }^{\circledR}$ (Applied Biosystems, Foster City, CA, Estados Unidos), utilizando sequenciador automático ABI-PRISM modelo $3100^{\circledR}$ (Applied Biosystems, Foster City, CA, Estados Unidos). As amostras foram traqueadas automaticamente utilizando software do Analisador Automático de DNA ABI Prism modelo 3100 .

Também foi testado o Applied Biosystems Big Dye ${ }^{\Theta}$ X-Terminator ${ }^{T M}$ Purification Kit (Applied Biosystems, Foster City, CA, Estados Unidos) seguindo as instruções do fabricante. 
4.9.2 Processamento e alinhamento das sequências dos genes N, P, M, G e L do vírus da raiva

As sequências de nucleotídeos foram alinhadas e analisadas com os programas BioEdit v7.0.9 (1997-2007, Tom Hall, Ibis Biosciences Carlsbad, CA) e CodonCode Aligner V3.0.1 (CodonCode Corporation), para obtenção de segmentos de nucleotídeos para os genes $\mathrm{N}, \mathrm{P}, \mathrm{M}, \mathrm{G}$ e L.

As sequências de nucleotídeos e aminoácidos foram alinhadas, juntamente com sequências adquiridas do GenBank, utilizando o programa BioEdit v7.0.9 (1997-2007, Tom Hall, Ibis Biosciences Carlsbad, CA) sendo então convertidas para o programa MEGA versão 4.0 (Tamura et al., 2007). Os arquivos foram analisados, com o referido programa, tendo como resultado a obtenção do grau de similaridade entre as sequências, calculadas par a par.

Posteriormente às análises filogenéticas o dataset de amostras alinhadas foi submetido ao programa MacClade 4.0 (Maddison e Maddison, 2000) para análises de substituição de aminoácidos em cada uma das regiões codificadoras de seus respectivos genes.

\subsection{Análise Genealógica}

Os arquivos gerados pelos programas de alinhamento BioEdit v7.0.9 (1997-2007, Tom Hall, Ibis Biosciences Carlsbad, CA) e MEGA 4.0 (Molecular Evolutionary Genetics Analysis software), disponível no site http://www.megasoftware.net/mega.html (Tamura et al., 2007) foram convertidos para formato NEXUS e utilizados para as análises genealógicas para as amostras de vírus da raiva, que foram realizadas empregando os critérios de Máxima Verossimilhança (maximum likelihood - ML) evolutivas utilizando o programa GARLi

(Genetic Algorhitm for Rapid Likelihood Inference), disponível no site http://www.bio.utexas.edu/faculty/antisense/garli/Garli.html (Zwickl, 2006). A árvore de ML (maximum likelihood) com as sequências de vírus da raiva foi gerada com uma busca heurística (heuristic search) com o algoritmo "Neighborn joining" (NJ) e para verificar a sustentação de ramos nas topologias das árvores obtidas, análises de bootstrap com 1000 réplicas (Felsenstein, 1985) e reamostragem de 200 caracteres foram feitas no programa GARLi (Zwickl, 2006). As anotações de valores de bootstrap nas árvores foram realizadas com o aplicativo TreeAnnotator do programa BEAST para Mac OS, disponível nos sites: http://tree.bio.ed.ac.uk/software/ ou http://beast.bio.ed.ac.uk/Main_Page. 


\section{RESULTADOS}

\subsection{Imunofluorescência Indireta e Cultivo Celular}

Os resultados dos testes de Imunofluorescência Indireta realizados com as amostras brdrusp100/07 e brbvusp01/06 apresentaram perfil antigênico compatível com a variante antigênica 3 - AgV3, mantida por populações de morcegos hematófagos D. rotundus.

O produto obtido do cultivo da amostra brdrusp100/07 em sistema de cultura celular BHK-21 permaneceu armazenado em freezer a $-70{ }^{\circ} \mathrm{C}$ durante o desenvolvimento dos testes.

\subsection{Desenho de Primers e Quantificação do RNA viral}

Para amplificar e sequenciar todo o genoma viral da variante do vírus da raiva isolada de morcego hematófago D. rotundus foram desenhados 33 oligonucleotídeos (Tabela 2). Os testes de amplificação das amostras utilizadas neste estudo, realizados a partir dos primers desenhados, mostraram que 32 dos 33 oligonucleotídeos foram eficientes.

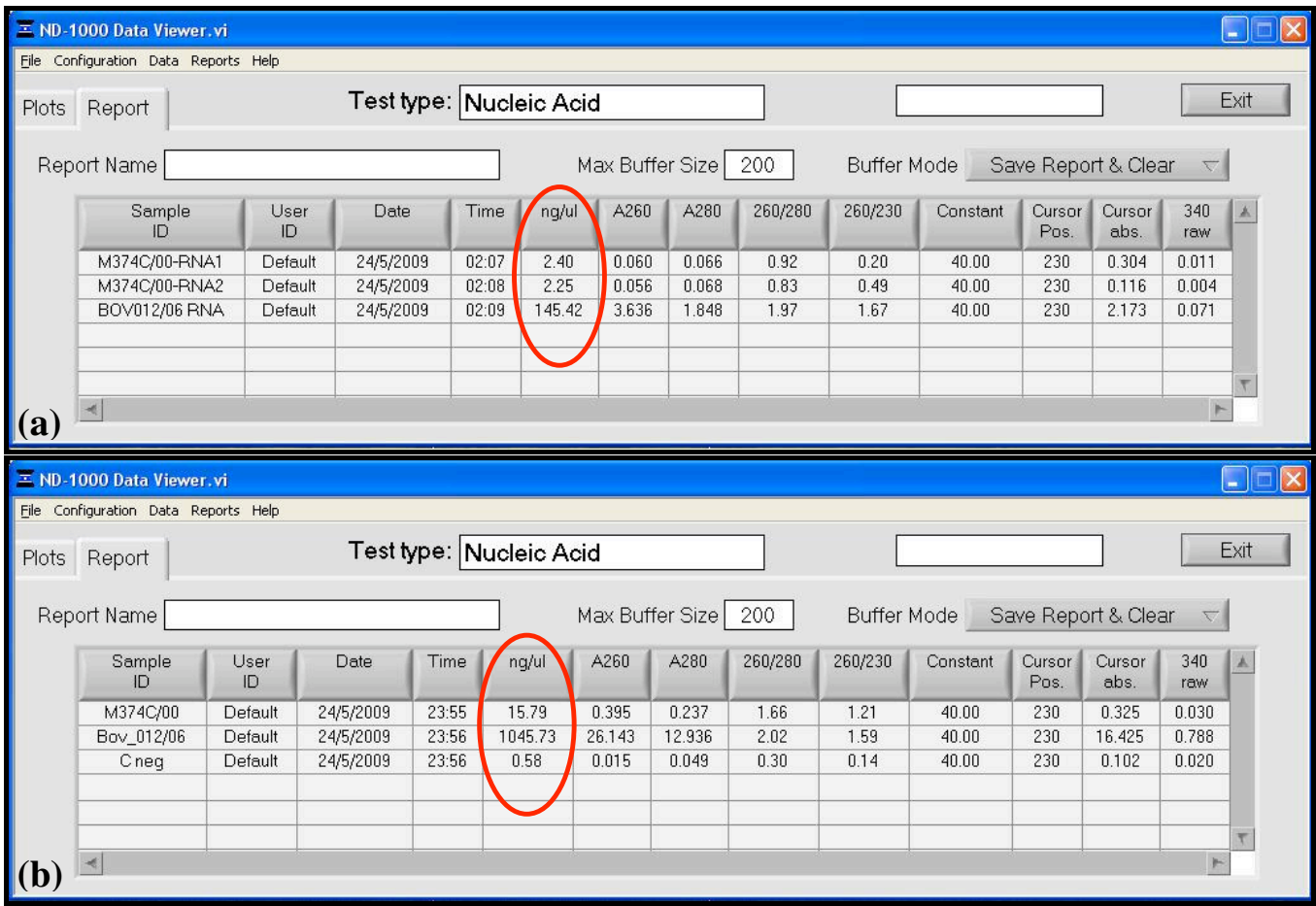

Figura 5. Visualização da quantificação de RNA para as amostras brdrusp100/07 e brbvusp01/06. As amostras brdrusp100/07 (identificada para o teste com o código M374C/00) e brbvusp01/06 (identificada para o teste com o código Bov_012/06). A quantidade de RNA após a extração está destacada. Em (a) quantificação realizada em uma data e em (b) quantificação realizada em data diferente após concentração das amostras. 
Tabela 2 - Oligonucleotídeos iniciadores para amplificação de genes do vírus da raiva

\begin{tabular}{|c|c|c|c|c|}
\hline Utilização & Primer & Posição no gene & Polaridade & Sequência \\
\hline RT-PCR e Seq. & Início_Posição1_F & $\begin{array}{c}1-22 \\
\text { Leader }\end{array}$ & + & ACgCTTAACAACAARATCARAg \\
\hline PCR e Seq. & SEQ_NuleoPr_F.750 & $\begin{array}{c}\text { 749-766 } \\
\text { Nucleoproteína }\end{array}$ & + & ggCACAgTWgTCACTgCT \\
\hline PCR e Seq. & NPM_1_F.1342 & $\begin{array}{c}1342-1361 \\
\text { Nucleoproteína }\end{array}$ & + & TgTCTCAgTCAgYTCCAATC \\
\hline PCR e Seq. & NPM_1_R.2479 & $\begin{array}{l}2480-2501 \\
\text { Fosfoproteína }\end{array}$ & - & gTTCATYTTATCAgTggTgTTg \\
\hline PCR e Seq. & NPM_2_F.2207 & $\begin{array}{l}\text { 2207-2226 } \\
\text { Fosfoproteína }\end{array}$ & + & ATgAACCTTgATgAYATAgT \\
\hline RT-PCR e Seq. & NPM_2_R.3428 & $\begin{array}{l}\text { 3428-3447 } \\
\text { Glicoproteína }\end{array}$ & - & ggRCAgCTgAgRTgATgTAT \\
\hline RT-PCR e Seq. & Glyco_F_pcr - A & $\begin{array}{c}\text { 3284-3303 } \\
\text { Intergênica M-G }\end{array}$ & + & СТАТСААСАТСССТСAAARg \\
\hline RT-PCR e Seq. & Glyco_F_Sato_pcr - C & $\begin{array}{c}3219-3237 \\
\text { Intergênica M-G }\end{array}$ & + & CgCTgCATTITRTCARAgT \\
\hline RT-PCR e Seq. & Glyco_R_pcr - B & $\begin{array}{l}5021-5038 \\
\text { Pseudogene }\end{array}$ & - & CAgTTgAgAKgATTgATg \\
\hline RT-PCR e Seq. & Glyco_R_pcr - D & $\begin{array}{l}5426-5443 \\
\text { Pseudogene }\end{array}$ & - & CgggTCATCATARACCTC \\
\hline PCR e Seq. & Glyco_seqF_1 & $\begin{array}{l}\text { 3987-4007 } \\
\text { Glicoproteína }\end{array}$ & + & gACTTgSggMTTTgTRgATgA \\
\hline PCR e Seq. & Glyco_seqR_1 & $\begin{array}{l}\text { 4120-4138 } \\
\text { Glicoproteína }\end{array}$ & - & gATCMggRgggCACCATTT \\
\hline PCR e Seq. & Glyco_seqF_2 & $\begin{array}{c}\text { 4120-4138 } \\
\text { Glicoproteína }\end{array}$ & + & AAATggTgCCCYCCKgATC \\
\hline PCR e Seq. & Glyco_seqR_2 & $\begin{array}{l}\text { 4520-4538 } \\
\text { Glicoproteína }\end{array}$ & - & TCCAACARYTCCATATgTT \\
\hline PCR e Seq. & Glyco_seqF_3 & $\begin{array}{l}\text { 4370-4390 } \\
\text { Glicoproteína }\end{array}$ & + & ggACTTggAACgARRTCATCC \\
\hline PCR e Seq. & Glyco_seqR_3 & $\begin{array}{c}\text { 4637-4656 } \\
\text { Glicoproteína }\end{array}$ & - & gAgAYCTgTTTgTGMACATC \\
\hline RT-PCR e Seq. & GliPol_1_F.5257 & $\begin{array}{l}\text { 5257-5275 } \\
\text { Glicoproteína }\end{array}$ & + & TgAAggACAKAAgCARTAg \\
\hline PCR e Seq. & GliPol_1_R.6270 & $\begin{array}{l}\text { 6270-6287 } \\
\text { Glicoproteína }\end{array}$ & - & AgTTCCRCACATRgACA \\
\hline PCR e Seq. & GliPol_2_F.6129 & $\begin{array}{l}\text { 6129-6147 } \\
\text { Glicoproteína }\end{array}$ & + & gAAACTACACACTTATgCT \\
\hline PCR e Seq. & GliPol_2_R.7295 & $\begin{array}{l}\text { 7294-7312 } \\
\text { Glicoproteína }\end{array}$ & - & ATACATCCTCTgTYgAYTC \\
\hline PCR e Seq. & GliPol_3_F.7158 & $\begin{array}{l}\text { 7157-7178 } \\
\text { Glicoproteína }\end{array}$ & + & TgACTATgACAgACAAYYTgAA \\
\hline PCR e Seq. & GliPol_3_R.8274 & $\begin{array}{l}8273-8290 \\
\text { Proteína L }\end{array}$ & - & gMAggCgAgTgAAgCTYT \\
\hline PCR e Seq. & GliPol_3_R_alternativa.8330 & $\begin{array}{l}8329-8348 \\
\text { Proteína L }\end{array}$ & - & TTgAgWAgAATggTgggACT \\
\hline PCR e Seq. & Pol_1_F.8185 & $\begin{array}{l}8184-8204 \\
\text { Proteína L }\end{array}$ & + & gAgAgARATYTggTTAAgCTC \\
\hline PCR e Seq. & Pol_1_R.9215 & $\begin{array}{l}\text { 9214-9233 } \\
\text { Proteína L }\end{array}$ & - & gTCAARTCAgACATSgTgTC \\
\hline PCR e Seq. & Pol_2_R.10316 & $\begin{array}{c}\text { 10315-10333 } \\
\text { Proteína L }\end{array}$ & - & CCTgTTgAgCAgAgCARAC \\
\hline PCR e Seq. & Pol_3_F.10226 & $\begin{array}{c}\text { 10225-10242 } \\
\text { Proteína L }\end{array}$ & + & gATCARgARgTKCgCCAT \\
\hline PCR e Seq. & Pol_3_R.11196 & $\begin{array}{c}\text { 11195-11217 } \\
\text { Proteína L }\end{array}$ & - & TATgATCATYTCATTRTAAggAT \\
\hline PCR e Seq. & Pol_4_F.10847 & $\begin{array}{c}\text { 10846-10866 } \\
\text { Proteína L }\end{array}$ & + & ATgTCYgATTTTgCATTgTCK \\
\hline PCR e Seq. & Pol_4_F_alternativa.11064 & $\begin{array}{c}\text { 11064-11084 } \\
\text { Proteína L }\end{array}$ & + & TgACСТCYTCYACСCTTCgAg \\
\hline PCR e Seq. & Pol_4_R.11616 & $\begin{array}{c}11616-11636 \\
\text { Proteína L }\end{array}$ & - & TCCAgTgAgATgAVAgACTCA \\
\hline RT-PCR e Seq. & PosicaoFINAL_R.11904 & $\begin{array}{c}11904-11924 \\
\text { Trailer }\end{array}$ & - & ACgCTТAACAAATAAACAACA \\
\hline
\end{tabular}

A quantificação do RNA realizada após a extração pode ser visualizada nas figuras 5a e 5b. A transcrição foi eficiente apenas quando quantidades acima de $145,42 \mathrm{ng} / \mu \mathrm{L}$ de RNA foram utilizadas, apresentando resultados positivos para amplificação (Figuras 5a e 5b). 
A figura 5a mostra a quantificação de RNA após uma extração. Os testes de amplificação posteriores a esta extração foram negativos para a amostra em estudo brdrusp100/07 e fracamente positivos para a amostra controle brbvusp01/06 com os iniciadores SeqN+304 da nucleoproteína.

A figura 5 b mostra os resultados da quantificação de RNA de outra extração executada a partir da concentração, por centrifugação a 20.000 g durante 2 horas, da amostra em estudo brdrusp100/07 e do controle brbvusp01/06.

\subsection{Síntese de cDNA e Amplificação Viral}

Tanto o teste de síntese de cDNA com o sistema Super Script ${ }^{\mathrm{TM}}$ Invitrogen $^{\circledR}$ (Invitrogen Corporation, Carlsbad, CA, Estados Unidos), quanto com o High Capacity cDNA Archive Kit ${ }^{\circledR}$ (Applied Biosystems, Foster City, CA, Estados Unidos) foram eficientes. A viabilidade do cDNA longo, desenvolvido neste trabalho, foi confirmada primeiramente com a amplificação parcial do gene $\mathrm{N}$ realizada com a combinação de primers SeqN+304 (765 pb) e posteriormente com a amplificação de fragmentos realizada com os demais conjuntos de primers para os demais genes estudados. A metodologia de síntese do cDNA com o cMaster $^{T M}$ RT kit (Eppendorf AG, Hamburg, Alemanha) não apresentou resultados satisfatórios sendo, portanto, desconsiderada.

Ao serem testadas diferentes temperaturas de anelamento para os oligonucleotídeos desenhados para este estudo, foi verificado que o protocolo já utilizado neste laboratório para amplificar a nucleoproteína, mostrou-se eficiente para algumas combinações dos novos conjuntos de primers como Início+304 (1.533 pb), SeqN+304 (765 pb), NPM1F+NPM2R (2.089pb), NPM1F+NPM1R (1.137 pb), NPM2F+NPM2R (1.221 pb), A+D (2.141 pb), C+D $(2.206 \mathrm{pb}), \quad$ GliPol1F+GliPol1R $(1.030 \mathrm{pb}), \quad$ GliPol1F+GliPol2R $(2.046 \mathrm{pb}) \quad \mathrm{e}$ GliPol3F+GliPol3R (1.133 pb). Por outro lado foi observado que para os demais fragmentos amplificados foram necessárias adaptações quanto a temperatura de anelamento e o número de ciclos.

Cada um dos genes codificadores para as proteínas do vírus da raiva encontra-se destacado na figura 6 que facilita a visualização das regiões abordadas neste trabalho. Os genes para nucleoproteína $(\mathrm{N})$, fosfoproteína $(\mathrm{P})$, proteína de matriz $(\mathrm{M})$, glicoproteína $(\mathrm{G})$ e polimerase (L) são separados por regiões intergênicas curtas e um longo pseudogene (entre as proteínas G e L). A sequência é flanqueada por uma região Leader (Le) na posição 3' e por uma região Trailer (Tr) na posição 5'. 


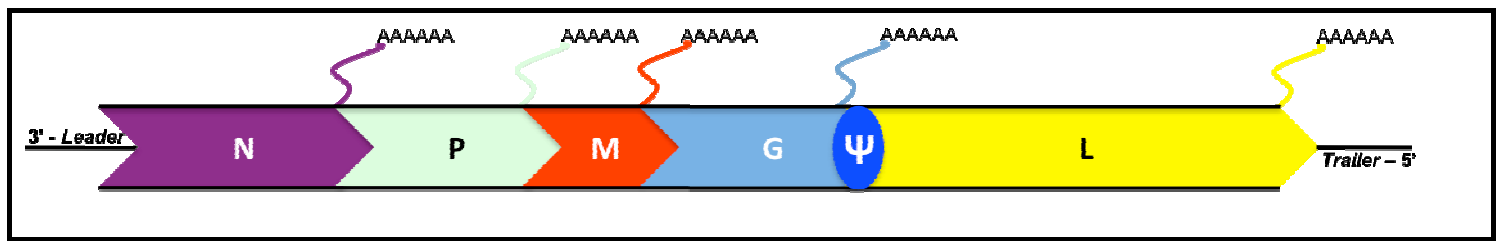

Figura 6. Esquema da organização do genoma do Vírus da Raiva e representação da cauda Poli-A.

Os resultados positivos da amplificação de fragmentos do vírus da raiva na amostra controle brbvusp01/06, utilizando as combinações Início+304 (1.533 pb) e 21g+304 (1.478 pb) estão demonstrados na figura 7. A combinação dos primers SeqN+304 (765 pb) também amplificou o fragmento esperado (dados não mostrados). O teste foi realizado em duplicata com amplificações realizadas a partir de cDNA randômico e a partir de cDNA específico MMLV sendo que os resultados foram eficientes para ambos os tipos de cDNA.

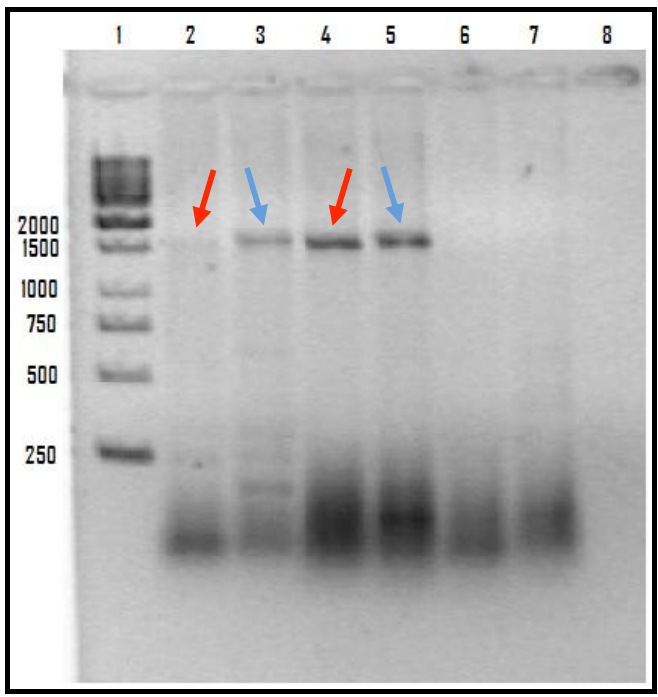

Figura 7. Eletroforese em gel de agarose $1,5 \%$ para nucleoproteína com a amostra controle brbvusp01/06.

O marcador de peso molecular aparece na canaleta 1. Nas canaletas 2 e 4 aparecem os resultados para a combinação $21 \mathrm{~g}+304$ (1.478 pb), nas canaletas 3 e 5 para a combinação Início+304 (1.533 pb), em 6 e 7 aparecem os controles negativos. As setas vermelhas indicam amplificações realizadas a partir de cDNA randômico e as setas azuis indicam amplificações realizadas a partir do cDNA MMLV.

As combinações de oligonucleotídeos NPM1F+NPM2R (2.089 pb - dados não mostrados), NPM1F+NPM1R (1.137 pb) e NPM2F+NPM2R (1.221 pb), desenhados para as proteínas $\mathrm{P}$ e M, foram utilizadas com sucesso, gerando fragmentos com tamanhos esperados para as duas amostras estudadas (figura 8). 


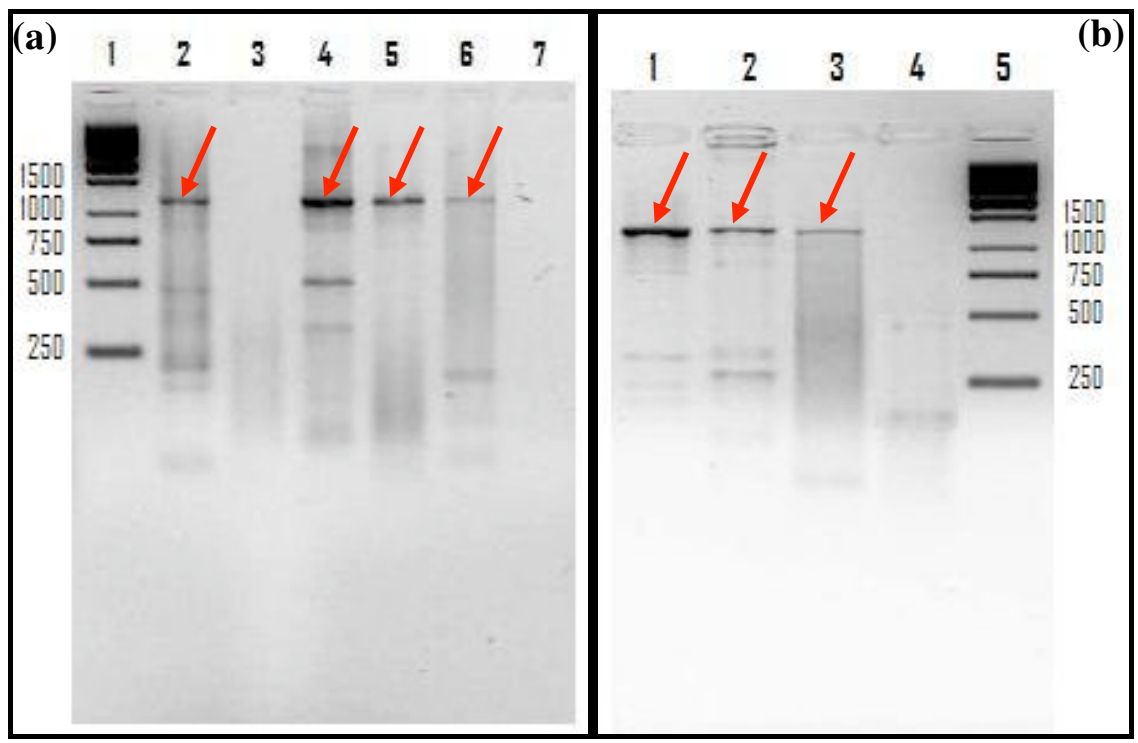

Figura 8. Eletroforese em gel de agarose 1,5\% para fosfoproteína e proteína de matriz.

O marcador de peso molecular aparece na canaleta 1 do primeiro gel (a) e na canaleta 5 do segundo gel (b). O primeiro gel apresenta resultados para a combinação NPM1F+NPM1R (amplificando $1.137 \mathrm{pb}$ do gene da fosfoproteína), na canaleta 2 aparece a amostra brbvusp01/06, na canaleta 3 controle negativo, em 4 amostra de outra variante testada paralelamente, em 5 e 6 aparece a amostra brdrusp100/07. O segundo gel (b) apresenta resultados para a combinação NPM2F+NPM2R (amplificando $1.221 \mathrm{pb}$ do gene da proteína de matriz), na canaleta 1 amostra brbvusp01/06, nas canaletas 2 aparece a amostra brdrusp100/07, em 3 amostra de outra variante testada paralelamente e em 4 controle negativo.

As reações de amplificação da glicoproteína foram realizadas em duplicata para cada uma das combinações de primers $\mathrm{A}+\mathrm{B}$ (esperado $1.736 \mathrm{pb}$ ), $\mathrm{C}+\mathrm{B}$ (esperado $1.801 \mathrm{pb}$ ), A+D (2.141 pb) e $\mathrm{C}+\mathrm{D}(2.206 \mathrm{pb})$. Nestes ensaios foi utilizado no primeiro tubo o cDNA específico para a glicoproteína viral, obtido com o sistema SuperScript ${ }^{\mathrm{TM}}$ Invitrogen $^{\circledR}$ (Invitrogen Corporation, Carlsbad, CA, Estados Unidos) e no segundo tubo foi utilizado o cDNA randômico obtido com o High Capacity cDNA Archive kit ${ }^{\circledR}$ (Applied Biosystems, Foster City, CA, Estados Unidos). Os testes com as combinações onde foi utilizado o primer B não amplificaram nenhum fragmento, indicando que este oligonucleotídeo não foi eficiente. As reações realizadas com as combinações de $\mathrm{A}+\mathrm{D}$ e $\mathrm{C}+\mathrm{D}$ apresentaram os produtos esperados e ainda, com a combinação C+D o material amplificado apresentou o melhor resultado com fragmentos únicos e maior quantidade de material amplificado (Figura 9). 


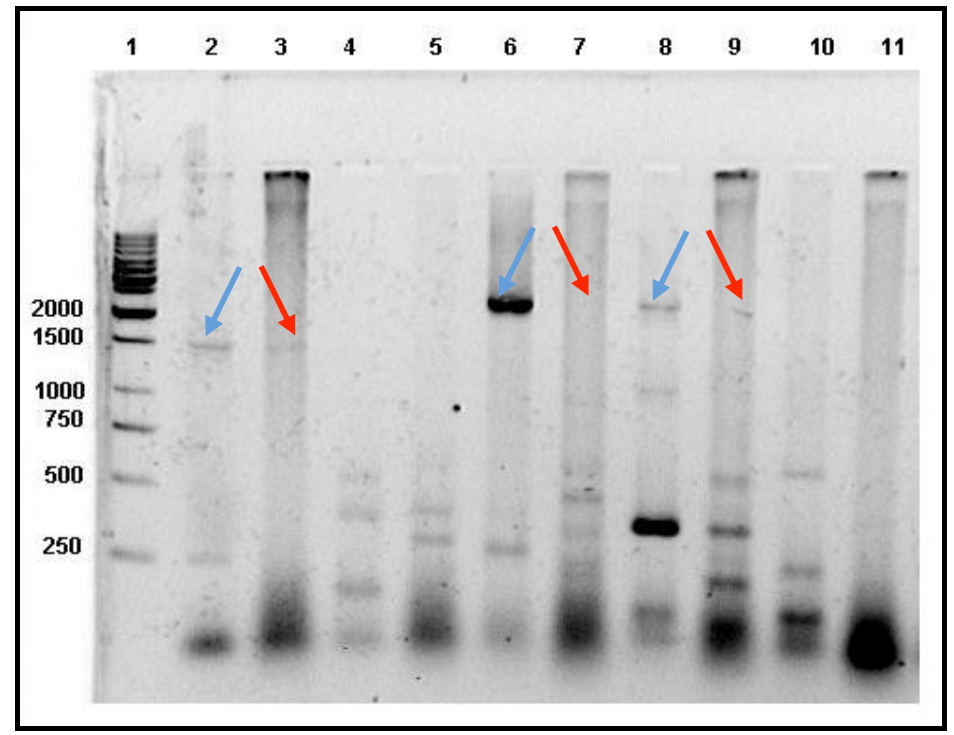

Figura 9. Eletroforese em gel de agarose 1,5\% para núcleo e glicoproteínas com a amostra controle brbvusp01/06.

O marcador de peso molecular aparece na canaleta 1. Nas canaletas 2 e 3 aparecem os resultados para a combinação 21g+304 (nucleoproteína), em 6 aparece o resultado para a combinação C+D (glicoproteína) e em 8 o resultado para a combinação A+D (glicoproteína), todos positivos. As setas azuis indicam amplificações a partir de um cDNA MMLV e as setas vermelhas indicam amplificações a partir de um cDNA randômico.

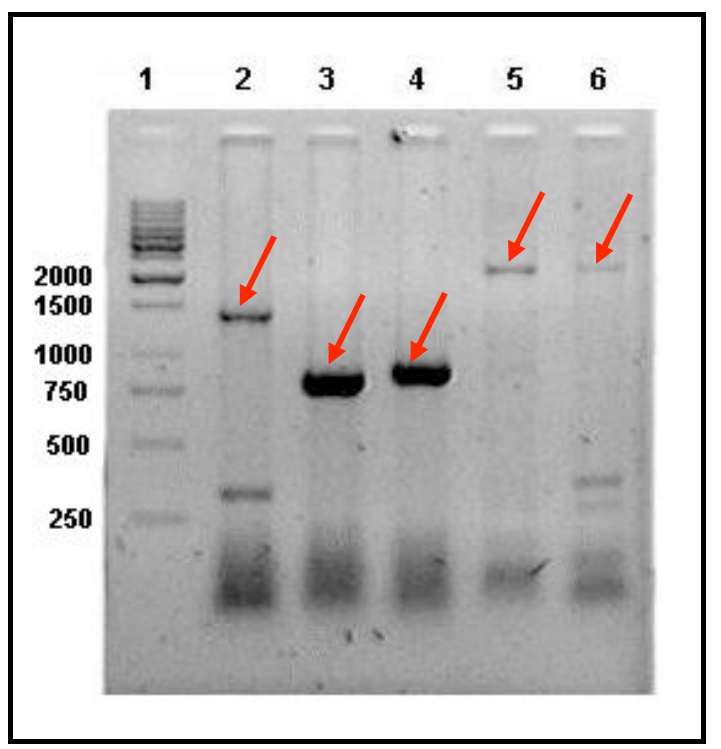

Figura 10. Eletroforese em gel de agarose 1,5\% para glicoproteína da amostra brbvusp01/06.

$\mathrm{O}$ marcador de peso molecular aparece na canaleta 1 . Na canaleta 2 aparece o resultado para a combinação $\mathrm{F} 1+\mathrm{D}$, na canaleta 3 para $\mathrm{A}+\mathrm{R} 1$, em 4 o resultado de $\mathrm{C}+\mathrm{R} 1$, em 5 aparece $\mathrm{A}+\mathrm{D}$ e em 6 aparece o resultado para a combinação $\mathrm{C}+\mathrm{D}$. Os resultados positivos estão assinalados pelas setas vermelhas.

A amplificação dos fragmentos de glicoproteína gerados a partir dos primers A+R1 $(836 \mathrm{pb}), \mathrm{A}+\mathrm{D}(2.141 \mathrm{pb}), \mathrm{F} 1+\mathrm{D}(1.433 \mathrm{pb}), \mathrm{C}+\mathrm{R} 1(901 \mathrm{pb})$ e $\mathrm{C}+\mathrm{D}(2.206 \mathrm{pb})$ foi eficiente para a amostra controle brbvusp01/06. Com estas combinações de primers foi possível a obtenção de material de melhor qualidade para o sequenciamento onde os fragmentos 
apresentavam grande quantidade de material genético amplificado (Figura 10). Nos produtos amplificados onde o fragmento era único a reação de sequenciamento foi realizada diretamente não sendo necessária a etapa de purificação.

Utilizando o cDNA longo padronizado nas primeiras etapas deste projeto foi possível amplificar com sucesso as combinações GliPol1F+GliPol2R (2.056 pb), GliPol2F+GliPol2R (1.184 pb), GliPol3F+GliPol3R (1.130 pb), Pol1F+Pol1R (1.049 pb), Pol1F+Pol2R (2.149 pb), Pol3F+Pol4R (1.410 pb) e Pol3F+Final (1.699 pb), resultando na amplificação total do genoma viral.

Combinações dos demais iniciadores da polimerase também foram testadas a partir do cDNA longo com sucesso para fragmentos de diversos tamanhos: GliPol1F+GliPol3R (fragmento esperado $3.034 \mathrm{pb}$ ), GliPol1F+GliPol2R (2.056 pb resultado positivo na figura 12), GliPol1F+GliPol1R (1.030 pb resultado positivo na Figura 13), GliPol2F+GliPol2R (1.184 pb), GliPol3F+GliPol3R (1.130 pb resultado positivo na Figura 11 canaletas 1 e 4), GliPol3F+Pol1R (2.076 pb), Pol1F+Pol3R (3.033 pb), Pol1F+Pol1R (1.049 pb), Pol2F+FINAL (2.926 pb), Pol2F+Pol4R (2.637 pb), Pol2F+Pol3R (2.219 pb), Pol2F+Pol2R (1.335 pb), Pol3F+Pol3R (992 pb), Pol3F+FINAL (1.699 pb), Pol4F+FINAL (1.076 pb) e Pol4F+Pol4R (787 pb).

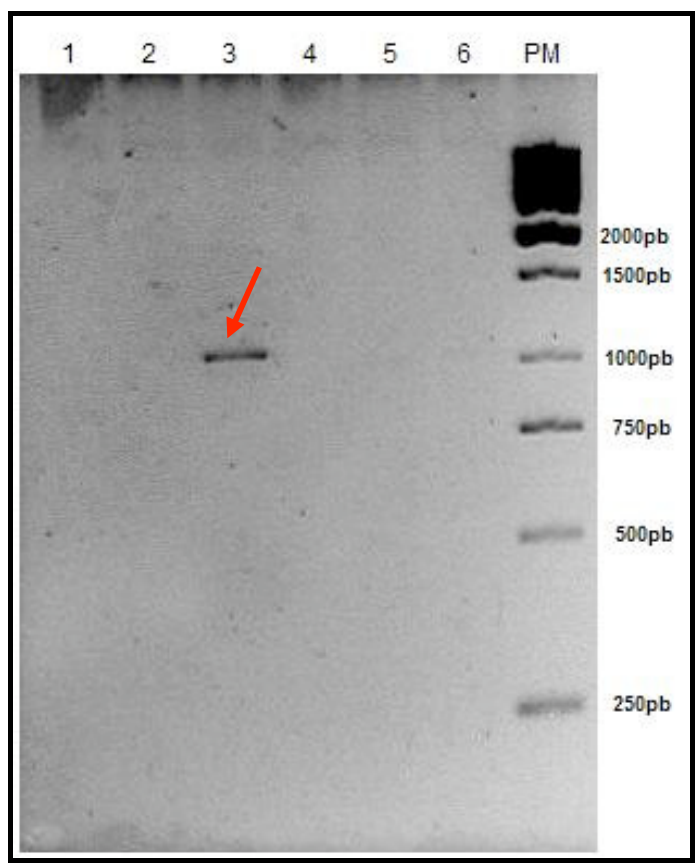

Figura 11. Eletroforese em gel de agarose $1,5 \%$ para fragmentos da polimerase viral.

O marcador de peso molecular na canaleta identificada com PM. Amplificação realizada com os primers GliPol1F+GliPol1R (1.030 pb) e cDNA sintetizado com Sistema SuperScript ${ }^{\mathrm{TM}}$. As canaletas 1 e 2 estão vazias, na canaleta 4 aparece o controle negativo. Na canaleta 3 está a amplificação da amostra brbvusp01/06, na canaleta 5 da amostra brdrusp100/07 e na canaleta 6 da amostra brsgusp32/07. A seta vermelha indica o resultado positivo. 
O protocolo de temperatura de anelamento foi testado para cada combinação de oligonucleotídeos, porém foram observados resultados positivos para apenas 3 combinações, GliPol1F+GliPol1R (1.030pb), GliPol3F+GliPol3R (1.133 pb) e GliPol1F+GliPol2R (2.046 pb), figuras 11,12 e 13 respectivamente.

A figura 11 mostra os resultados para a combinação GliPol1F+GliPol1R (1.030 pb) que amplifica um fragmento inicial da polimerase viral. Apenas na canaleta 3 pode ser visualizado o resultado positivo para a amostra controle brbvusp01/06.

As amplificações da polimerase viral, a partir do cDNA longo, com os primers GliPol3F+GliPol3R (1.133 pb) e GliPol1F+GliPol2R (2.046 pb) foram positivas para a amostra controle brbvusp01/06 (figuras 12 e 13). Nestes testes de amplificação os resultados para a amostra brdrusp100/07 foram negativos.

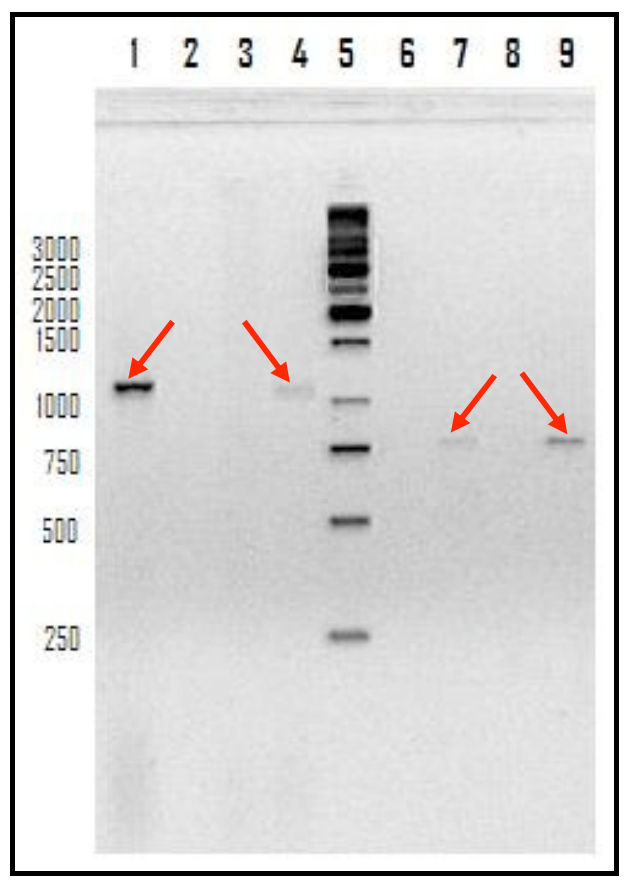

Figura 12. Eletroforese em gel de agarose $1,5 \%$ fragmentos da polimerase viral.

O marcador de peso molecular aparece na canaleta 5. Nas canaletas de 1 a 4 GliPol3F+GliPol3R $(1.133 \mathrm{pb})$ e de 6 a $7 \mathrm{SeqN}+304(787 \mathrm{pb})$. Nas canaletas 1 e 7 aparecem uma amostra de outra variante testada paralelamente e em 3 e 9 a amostra brbvusp01/06. Nas canaletas 2 e 8 estão a amostra brdrusp100/07, em 3 e 6 aparecem os controles negativos. As setas vermelhas indicam os fragmentos amplificados.

A combinação GliPol1F+GliPol2R $(2.046 \mathrm{pb})$ foi novamente testada para as duas amostras em estudo e em duplicata a partir de cDNAs específicos para polimerase viral sintetizados com os sistemas SuperScript ${ }^{\mathrm{TM}}$ e $c$-Master. Os resultados positivos para a 
amostra controle brbvusp01/06 e o resultado negativo para a amostra brdrusp100/07 são visualizados na figura 13 . Todos os testes com o kit $c$-Master foram negativos.

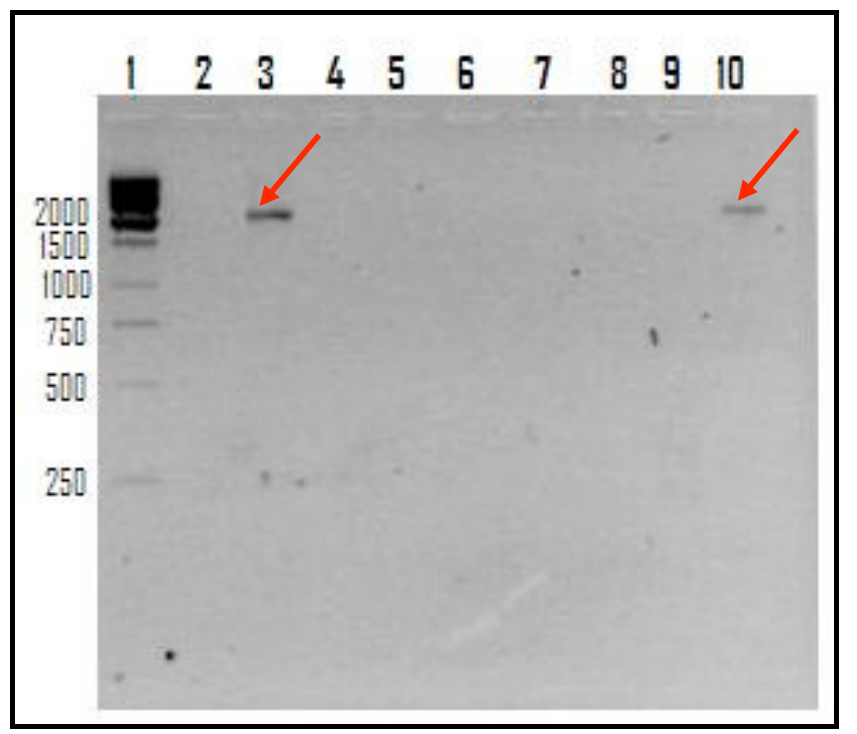

Figura 13. Eletroforese em gel de agarose 1,5\% para fragmentos da polimerase viral

$\mathrm{O}$ marcador de peso molecular aparece na canaleta 1. Amplificação realizada com os primers GliPol1F+GliPol2R (2.056 pb). As canaletas 5 e 8 estão vazias, na canaleta 4 aparece o controle negativo. Nas canaletas 3 e 10 aparecem a amostra brbvusp01/06 amplificadas a partir de cDNA sintetizado com Sistema SuperScript ${ }^{\mathrm{TM}}$, nas canaletas 2 e 9 aparecem a amostra brdrusp100/07 (cDNA sintetizado com Sistema SuperScript ${ }^{\mathrm{TM}}$ ), na canaleta 6 a amostra brdrusp100/07 (cDNA Sistema $c$-Master) e na canaleta 7 a amostra brbvusp01/06 amplificada a partir de cDNA sintetizado com Sistema $c$-Master. As setas vermelhas indicam os resultados positivos, apenas em 3 e 10.

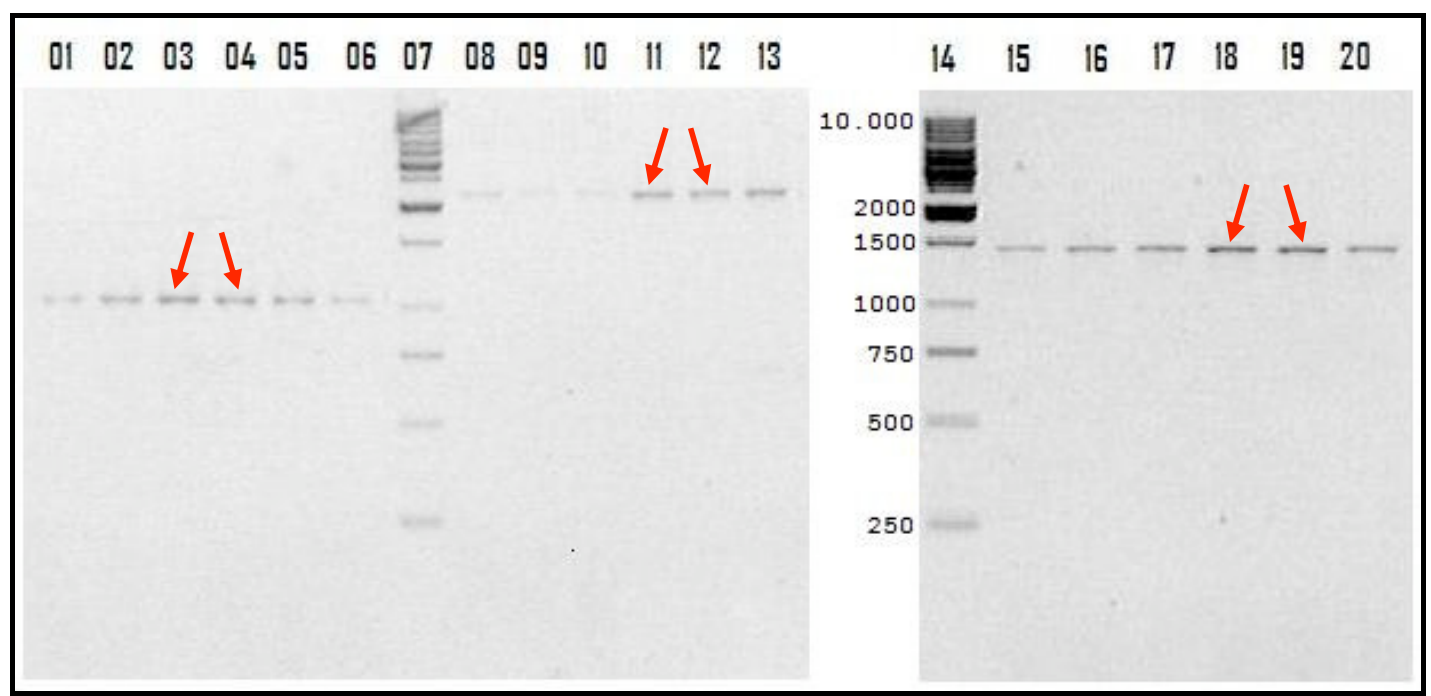

Figura 14. Eletroforese em gel de agarose $1,5 \%$ de um gradiente de temperatura para a amostra controle brbvusp01/06.

$48{ }^{\circ} \mathrm{C}$ nas canaletas 1,8 e $15,50{ }^{\circ} \mathrm{C}$ em 2,9 e $16,52{ }^{\circ} \mathrm{C}$ em 3,10 e $17,54{ }^{\circ} \mathrm{C}$ em 4,11 e $18,56{ }^{\circ} \mathrm{C}$ em 5,12 e 19 e $58^{\circ} \mathrm{C}$ em 6,13 e $20 . \mathrm{O}$ marcador de peso molecular que aparece nas canaletas 7 e 14. Nas canaletas de 1 a 6 aparecem os resultados para a combinação Pol1F+Pol1R (1.049 pb), nas canaletas de 08 a 13 para a combinação Pol1F+Pol2R (2.149 pb) e nas canaletas de 14 a 20 aparece a combinação Pol3F+Pol4R (1.410 pb). 
As combinações Pol1F+Pol1R (1.049 pb), Pol1F+Pol2R (2.149 pb) e Pol3F+Pol4R (1.410 pb) com amostra bovina para amplificação da polimerase viral, submetidas a testes de gradiente para a identificação da temperatura ótima de anelamento de $48{ }^{\circ} \mathrm{C}$ a $58{ }^{\circ} \mathrm{C}$ com aumento de $2{ }^{\circ} \mathrm{C}$ em cada reação, indicaram $52{ }^{\circ} \mathrm{C}$ para Pol1F+Pol1R e $56{ }^{\circ} \mathrm{C}$ para as combinações Pol1F+Pol2R e Pol3F+Poll4R como as temperaturas ótimas de anelamento (Figura 14).

A partir das padronizações descritas anteriormente, utilizando a amostra brbvusp01/06, os testes de amplificação foram aplicados para a amostra de vírus da raiva isolada de morcego hematófago D. rotundus brdrusp100/07. Os resultados da PCR, com a amostra de morcego, positivos para o conjunto de oligonucleotídeos GliPol3F+GliPol3R $(1.130 \mathrm{pb})$ e negativo para GliPol1F+GliPol2R (2.056 pb) são apresentados na figura 15.

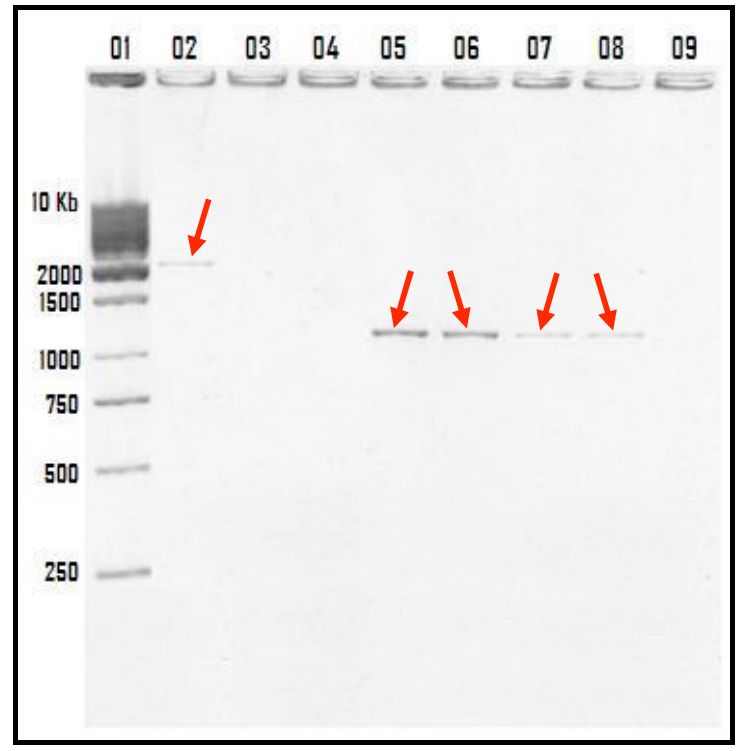

Figura 15. Eletroforese em gel de agarose 1,5\% para fragmentos da polimerase viral.

$\mathrm{O}$ marcador de peso molecular aparece na canaleta 1. Amplificação realizada com os primers GliPol1F+GliPol2R (2.056 pb) na canaleta 2 onde aparece a amostra brbvusp01/06, na canaleta 3 aparece o controle negativo, a canaleta 4 está vazia. Nas canaletas de 5 a 9 estão os testes com os primers GliPol3F+GliPol3R (1.130 pb). Nas canaletas 5 e 6 aparece a amostra brdrusp100/07 amplificada a partir de cDNA longo, nas canaletas 7 e 8 aparece a amostra brbvusp01/06, na canaleta 9 aparece o controle negativo.

Com o intuito de aperfeiçoar o rendimento da reação de amplificação para o conjunto Pol1F+Pol2R (2.149 pb) foi testado uma variação no número de ciclos da reação de PCR (touchdown) para as amostras de bovino e de morcego hematófago. Os resultados foram comparados com os obtidos na opção de ciclos utilizados nos testes anteriores mostrando que a otimização do ciclo foi mais eficiente para essa combinação de primers (Figura 16). 


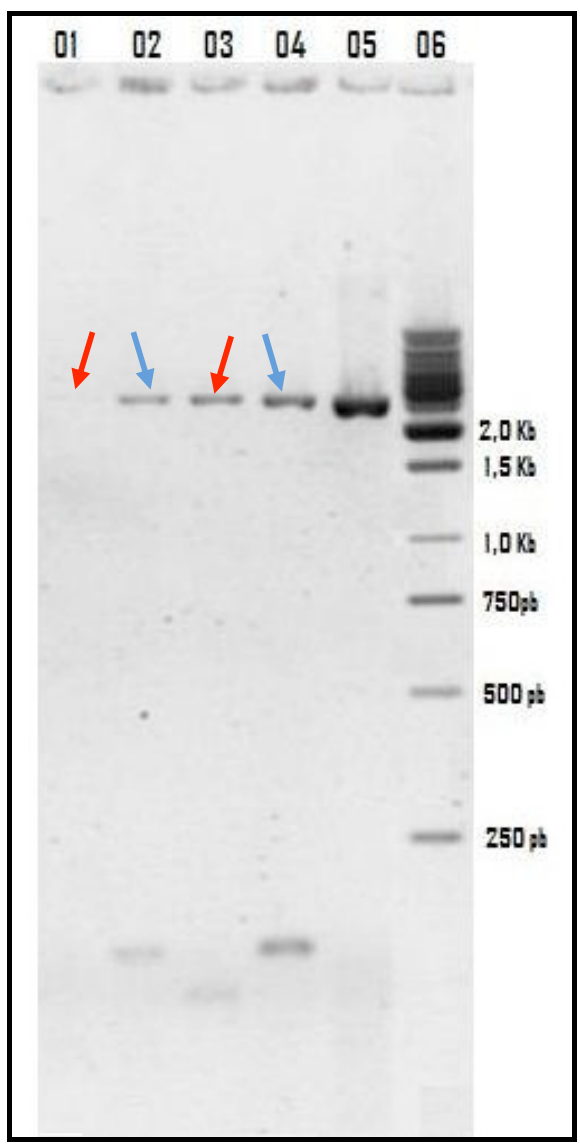

Figura 16. Eletroforese em gel de agarose 1,5\% para fragmentos da polimerase viral.

$\mathrm{O}$ fragmento amplificado foi de $2.149 \mathrm{pb}$ amplificados com os oligonucleotídeos Pol1F+Pol2R. O marcador de peso molecular aparece na canaleta 6 . Nas canaletas 1 e 3 aparecem os resultados para a amostra brbvusp01/06 e em 2 e 4 a amostra brdrusp100/07, em 5 aparece a amostra brsgusp32/07. Nas canaletas 1 e 2 foram utilizados 35 ciclos e nas canaletas 3, 4 e 5 foram utilizados o touchdown de 40 ciclos. As setas vermelhas indicam a comparação entre os fragmentos da amostra brbvusp01/06 e as setas azuis indicam a comparação entre os ciclos para a amostra brdrusp100/07.

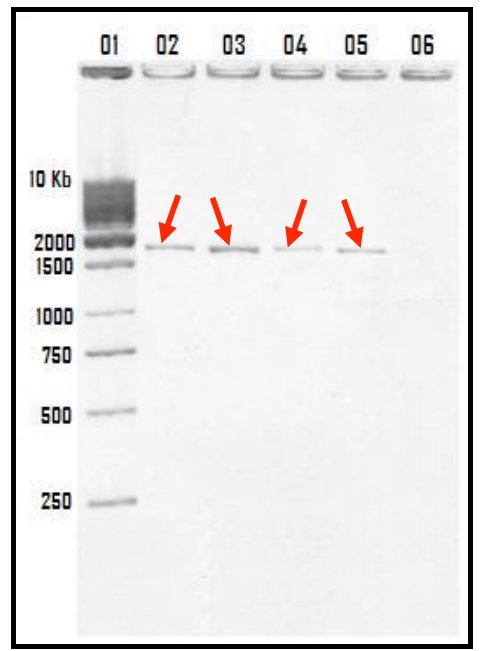

Figura 17. Eletroforese em gel de agarose $1,5 \%$ para fragmentos da polimerase viral.

O marcador de peso molecular aparece na canaleta 1 . Nas canaletas 2 e 3 aparece a amostra brdrusp100/07 e em 4 e 5 a amostra brbvusp01/06, em 6 aparece o controle negativo. As setas vermelhas indicam os fragmentos de $1.699 \mathrm{pb}$ amplificados com os oligonucleotídeos Pol3F+Final. 
O resultado positivo para as amostras de bovino brbvusp01/06 e morcego hematófago brdrusp100/07, com o conjunto Pol3F+Final (1.699 pb), que amplifica um fragmento da porção terminal da polimerase e a região 5' Trailer, está apresentado na figura 17.

A figura 18 mostra um exemplo da quantificação do fragmento viral amplificado com as combinações de iniciadores Pol1F+Pol2R (2.149 pb) e P784+304 (849 pb). O teste foi realizado para as amostras brdrusp100/07 (canaletas 2, 4 e 7), brbvusp01/06 (canaletas 3, 5 e 8) e brsgusp32/07 (canaletas 6 e 9), onde podem ser visualizados fragmentos apresentando de menos de 10ng/4 $\mu \mathrm{L}$ de DNA (canaleta 2) a próximo de $120 \mathrm{ng} / 4 \mu \mathrm{L}$ (canaleta 8). Foram aplicados $4 \mu \mathrm{L}$ de cada amostra e também do low DNA mass ladder Invitrogen ${ }^{\circledR}$ (Invitrogen Corporation, Carlsbad, CA, Estados Unidos).

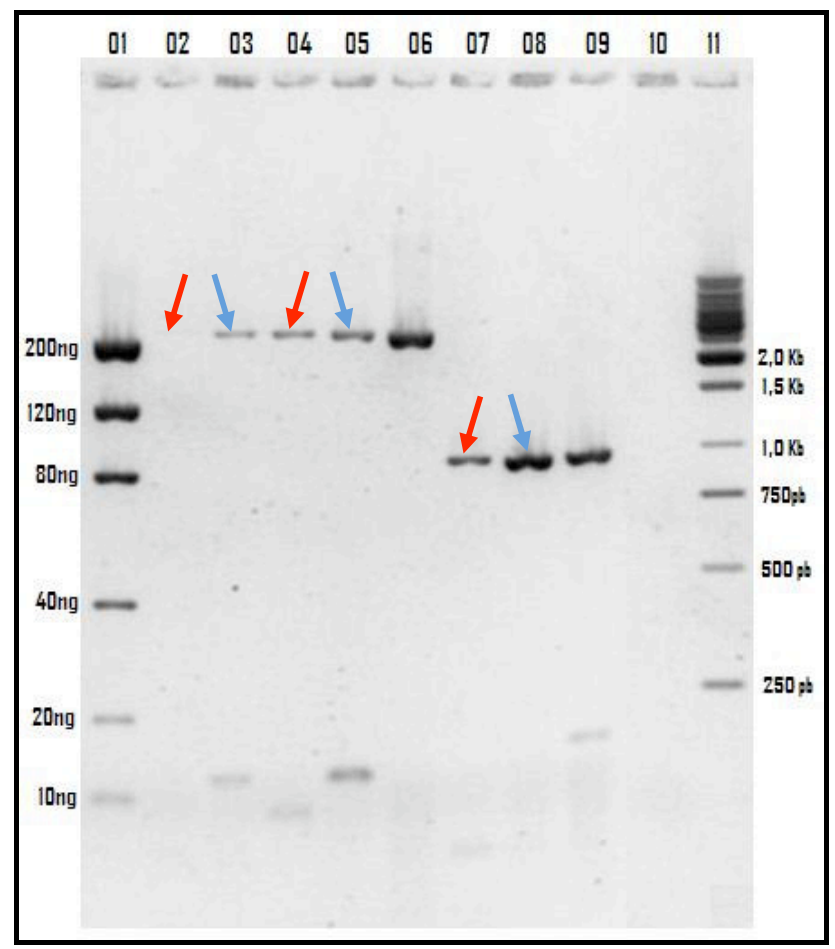

Figura 18. Eletroforese em gel de agarose $1,5 \%$ para fragmentos da polimerase viral.

O marcador de peso molecular na canaleta 11. Na canaleta 1 aparece o low DNA mass ladder e nas canaletas de 2 a 6 aparecem os fragmentos amplificados da polimerase com os oligonucleotídeos Pol1F+Pol2R (2.149 pb). Nas canaletas de 7 a 9 aparecem os fragmentos amplificados de $849 \mathrm{pb}$ de nucleoproteína com o conjunto P784+304. Na canaleta 10 aparece o controle negativo. As setas azuis indicam a comparação entre os fragmentos da amostra brbvusp01/06 nas canaletas 3 e 5 para diferentes ciclos de amplificação da polimerase e na canaleta 8 da nucleoproteína e as setas vermelhas indicam a comparação entre os fragmentos da amostra brdrusp100/07 nas canaletas 2 e 4 para diferentes ciclos da polimerase e na canaleta 7 da nucleoproteína. A amostra brsgusp32/07 aparece nas canaletas 6 e 9 . 
Com objetivo de amplificar o gene da Polimerase e o genoma completo do vírus da raiva, a partir de uma única reação com uso de cDNA longo, foram realizados ensaios com o Kit Expand Long Template PCR System ${ }^{\circledR}$ (Roche Diagnostics GmbH, Mannheim, Alemanha) e as amostras controle de bovino brbvusp01/06 e de morcego brdrusp100/07. Foram testadas tanto a combinação de primers GliPol1F+FINAL (6.650 pb) para amplificação da polimerase, quanto as combinações Início+FINAL (11.932 pb) e Início+Pol4R (11.643 pb) para a amplificação do genoma completo. Os resultados destes ensaios foram fracamente positivos apenas para amplificação do genoma completo da amostra controle brbvusp01/06 (Figura 19).

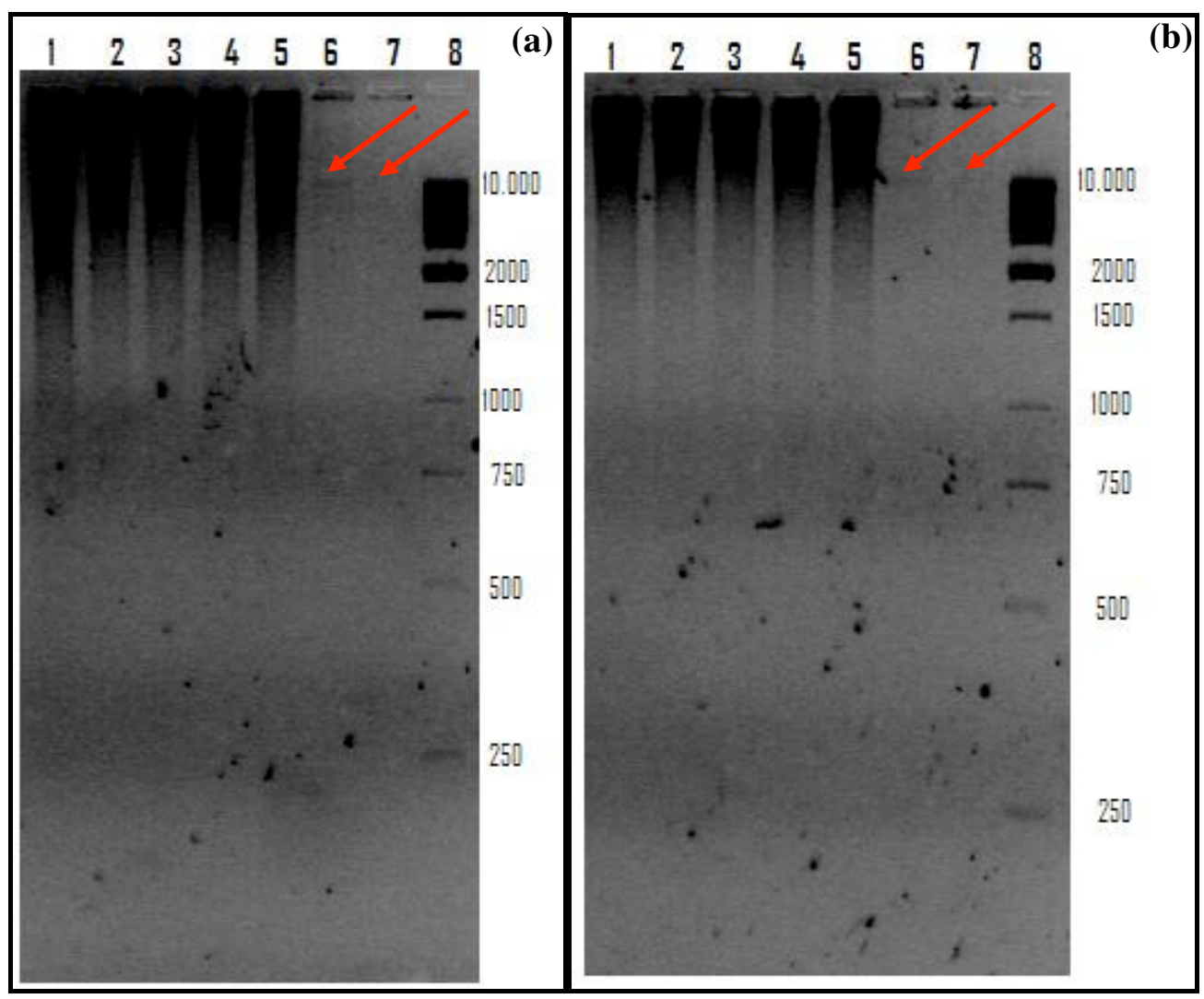

Figura 19. Eletroforese em gel de agarose $1,5 \%$ da amplificação do genoma completo.

O marcador de peso molecular aparece nas canaletas 8 (a e b). Em (a) os testes para a combinação Início+FINAL e em (b) Início+Pol4R, nas canaletas de 1 a 4 estão testes com diferentes quantidades de cDNA para a amostra brbvusp01/06, na canaleta 5 aparece a amostra brdrusp100/07, e nas canaletas 6 e 7 a amostra brbvusp01/06 em duplicata com fragmentos superiores a $10 \mathrm{~kb}$ indicados pelas setas vermelhas, em 8 está o marcador de $1 \mathrm{~Kb}$. Testes realizados com enzima Expand Long.

Após a obtenção do fragmento de DNA viral longo contendo o genoma viral completo (cerca de $12 \mathrm{~Kb}$ ), foram realizados ensaios de sequenciamento sem sucesso, possivelmente devido a baixa quantidade de material obtida após a PCR. Com intuito de concentrar o material amplificado, foi testado a realização de uma reação de Nested-PCR e de SemiNested- 
PCR, porém não foi observado amplificação mesmo após o uso destes protocolos. Os resultados obtidos nesta etapa demonstraram que, a metodologia utilizada para a concentração não se mostrou satisfatoriamente eficiente.

Com objetivo de possibilitar o sequenciamento direto de fragmentos longos, foram retomados os testes para a amplificação de todo o genoma viral em uma única reação (11.932 pb) utilizando o kit Expand Long Template PCR System (Roche ${ }^{\circledR}$ Diagnostics GmbH, Mannheim, Alemanha). Ao serem realizadas adaptações nas quantidades de enzima e dos diferentes tampões os resultados obtidos nestes ensaios foram promissores (Figura 20) uma vez que geraram bandas com maior intensidade quando comparado aos resultados do primeiro ensaio com este kit (Figura 19)

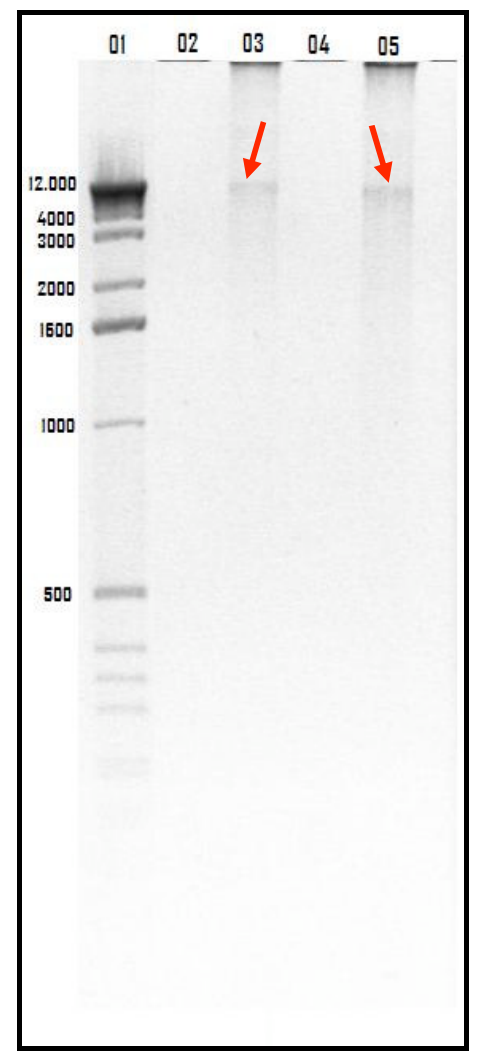

Figura 20. Eletroforese em gel de agarose 1,0\% da amplificação do genoma completo.

$\mathrm{O}$ marcador de peso molecular pode ser visualizado na canaleta 1 . Nas canaletas 3 e 5 aparecem o resultado para a combinação Início+FINAL (11.932 pb) para a amostra brbvusp01/06 em duplicata as canaletas de 2 e 4 estão vazias. Os fragmentos superiores a 10kb estão indicados pelas setas vermelhas.

\subsection{Quantificação e Sequenciamento}

Após a amplificação e purificação dos fragmentos, os mesmos foram quantificados com o equipamento Thermo Scientific NanoDrop ${ }^{\mathrm{TM}} 1000$ Spectrophotometer $_{\text {Thermo }}$ (Thermo 
Fisher Scientific Inc., Waltham, MA, Estados Unidos), para serem usados como molde na reação de sequenciamento (Figura21 e 22).

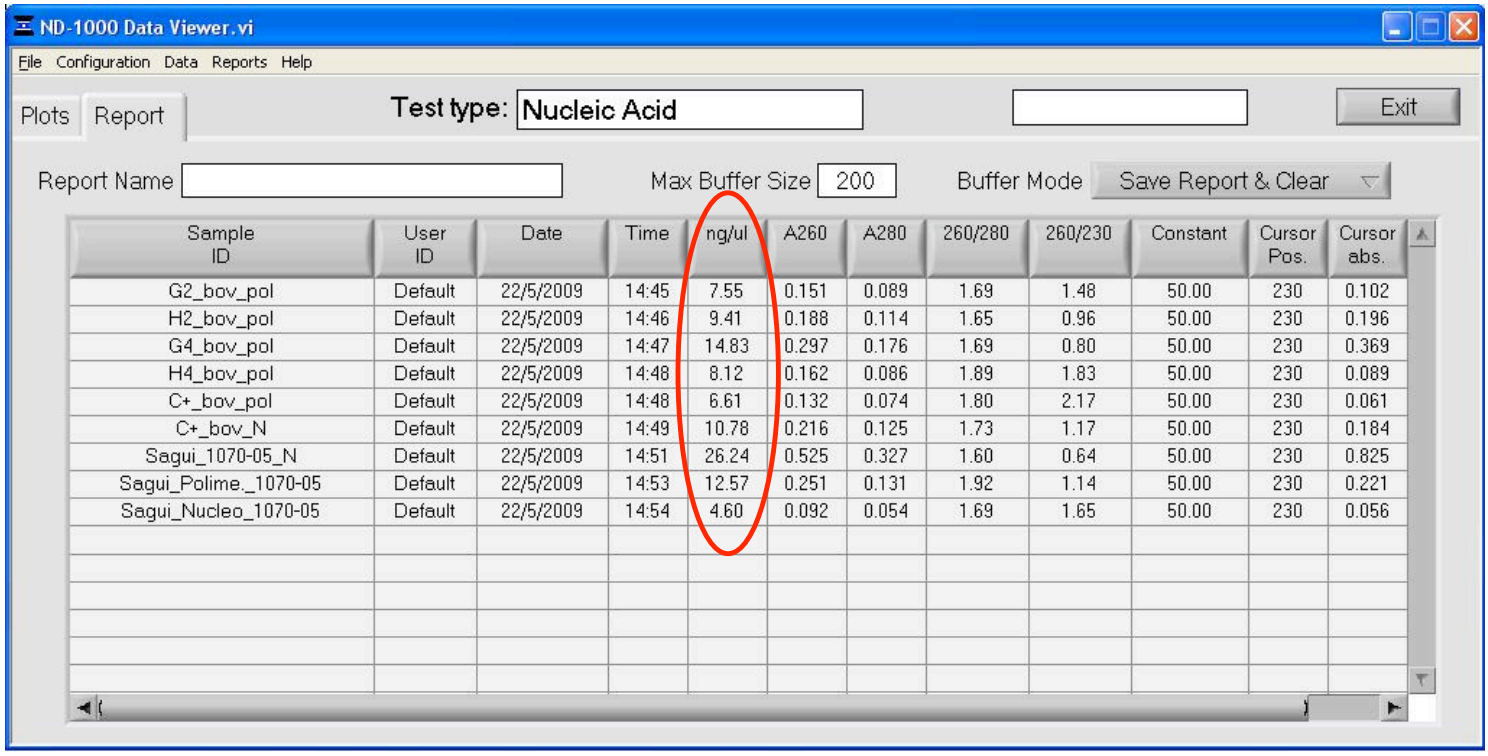

Figura 21. Visualização da quantificação de DNA

A amostra brsgusp32/07 (proveniente de sagui e identificada para o teste como 1070/05) e amostra brbvusp01/06 (identificada para o teste como BOV012/06). A quantidade de DNA está destacada. Cada linha representa um fragmento amplificado.

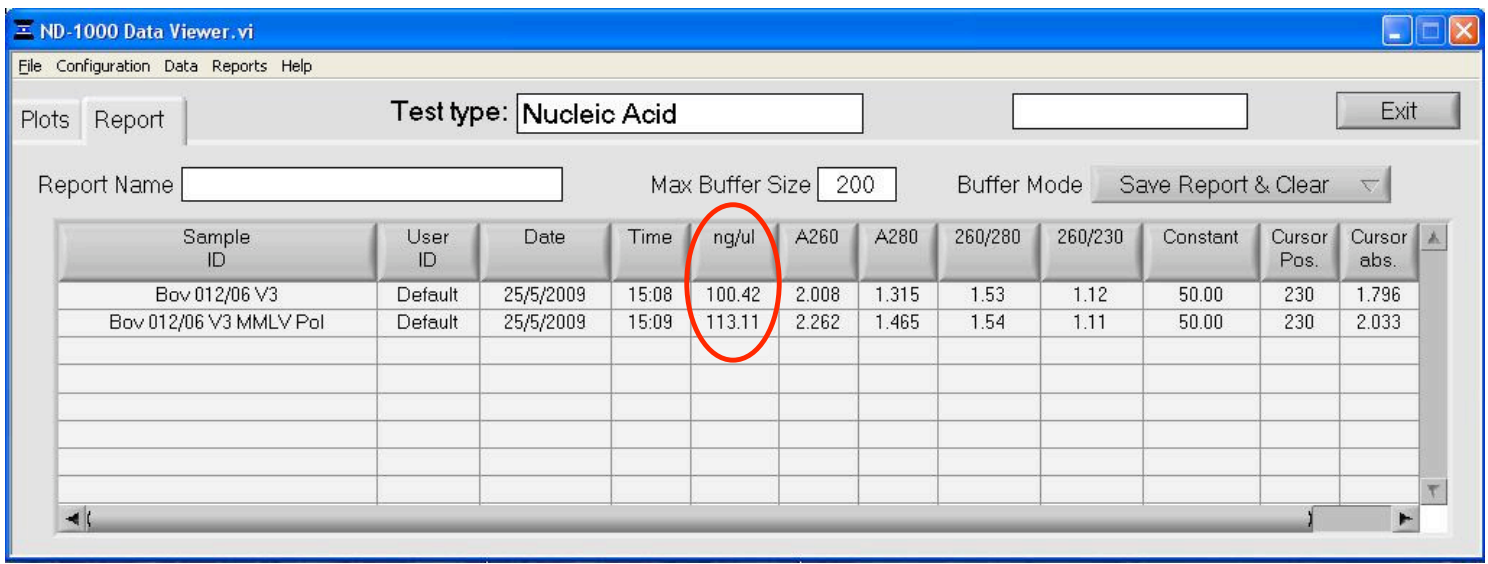

Figura 22. Visualização da quantificação de DNA para a amostra brbvusp01/06.

A amostra brbvusp01/06 (identificada para o teste como BOV012/06). A quantidade de DNA está destacada. Cada linha representa um fragmento amplificado.

Os produtos quantificados foram sequenciados e analisados. Inicialmente foram alinhadas as sequências dos genes codificadores para a nucleoproteína e glicoproteína para a observação dos sítios antigênicos. No sítio antigênico I, localizado na região carboxi terminal da nucleoproteína, foram identificadas substituições de aminoácidos nos resíduos 377 a 379, próprias da variante mantida por morcegos hematófagos D. rotundus (Figura 23). No gene 
codificador para a glicoproteína apenas foi observada uma substituição no resíduo 218 presente no sítio antigênico IIa (Figura 24).

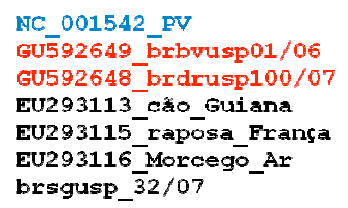
RDEKELQEYE AAELTKTDVA LADDGTVNSD DEDYESGETR SPEAVYTRIM MNGGRLKRSH RDEKELQEYE AAELTKTEMA LADDGTWNSD DEDNFSSETR SPEAVYTRIM MNGGRLKRSH RDERELQEHE AAEMMKTEAA LADDGTVNSD DEDYFSNETR SPEAVYTRIM MNGGRLKRSH

Figura 23. Ilustração comparativa do sítio antigênico I na região carboxi terminal da nucleoproteína $\mathbf{N}$. Observação das modificações de aminoácidos do sítio antigênico I na região carboxi-terminal da nucleoproteína e observação da Serina conservada entre os vírus da raiva padrão PV (NC_001542), amostra controle bovino brbvusp01/06 (GU592649) e amostra morcego brdrusp100/07 (GU592648) do Brasil, cão da Guiana (EU293113), raposa da França (EU293115), morcego insetívoro Tadarida brasiliensis da Argentina (EU293116) e sagui Callitrhix jacchus do Brasil (brsgusp32/07), amostras representativas de ciclos de transmissão no Brasil.

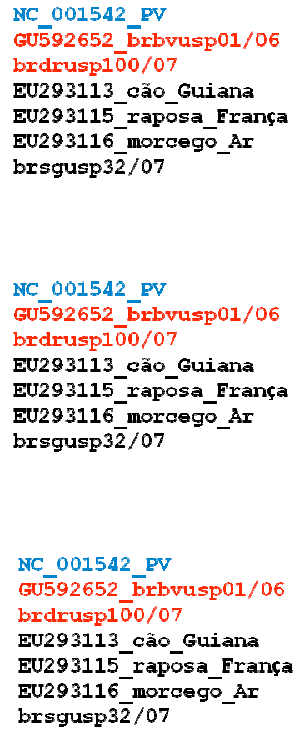
ECLDALESIM TTKSVSERRL SHLRKLVPGE GKAYTIFNKT LMEADAHYKS VRTWNEIIPS KGCLKVRERC BCLDALESIM TTKSVSERRL SYLRKLVPGE GKAYTIFNKT LMEADAHYKS VRTWNEIIPS KGCLKVRERC BCLDALESIM TTKSVSFRRL SYLRKLVPGF GKAYTIFNKT LMEADAHYKS VRTWNEIIPS KGCLKVRERC FCLDA BCLDALESIM TTKSVSERRL SHLRKLVPGF GKAYTIFNKT LMEADAFYKS VRTWNEIIPS KGCLKVGGRC BCLDALESIM TTKSVSERRI SHLRKLVPGE GKAYTIYNKT LMEADAHYKS VRTWNEIIPS KGCLRVGGRC

Figura 24. Ilustração comparativa dos sítios antigênicos localizados na glicoproteína G.

Observação das modificações de aminoácidos nos sítios antigênicos IIb, IIa e III na Glicoproteína entre as amostras de vírus da raiva PV (NC_001542), brbvusp01/06 (GU592652) e brdrusp100/07 (bovino e morcego Desmodus rotundus do Brasil), EU293113 (cão da Guiana), EU293115 (raposa da França), EU293116 (morcego insetívoro Tadarida brasiliensis da Argentina) e brsgusp32/07 (sagui Callithrix jacchus do Brasil), padrão e amostras representativos de ciclos de transmissão do vírus da raiva.

\subsection{Análises Genealógicas}

A análise do fragmento de 320 nucleotídeos do gene codificador para a nucleoproteína confirmou a variante genética relacionada à mantida por populações de morcegos hematófagos $D$. rotundus como pode ser visualizada na figura 25. 


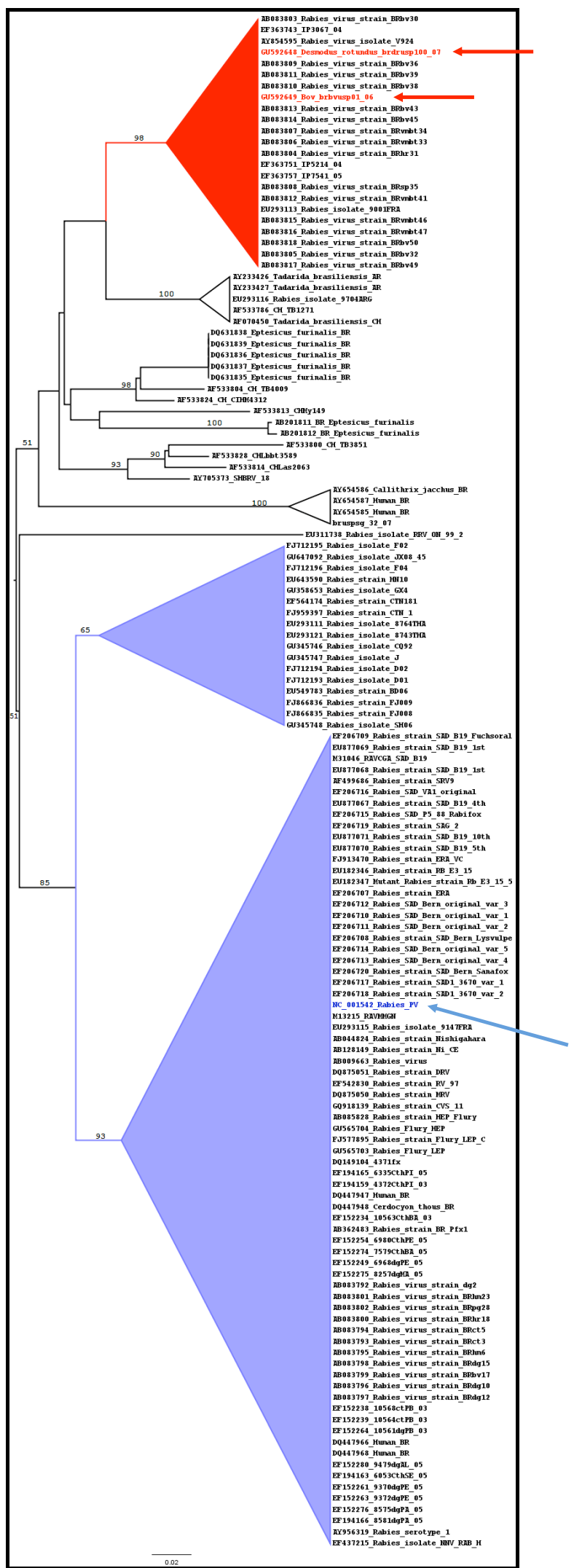

Figura 25. Árvore filogenética de máxima verossimilhança (ML) para nucleoproteína (parcial). Análise 320 nucleotídeos da região carboxi terminal da nucleoproteína, reconstruída pelo programa MEGA4 e realizada uma busca heurística (heuristic search) com o algorítmo "NJ". Os valores nos principais nós representam os valores de 10000 réplicas de bootstrap superiores a $50 \%$. 
O sequenciamento e alinhamento dos fragmentos amplificados dos genes $\mathrm{N}, \mathrm{P}, \mathrm{M}, \mathrm{G}$ e partes do gene L, resultaram nas análises genealógicas para cada um dos genes $(\mathrm{N}, \mathrm{P}, \mathrm{M}, \mathrm{G}) \mathrm{e}$ fragmentos (L) de interesse, para a amostra controle brbvusp01/06 e para a amostra de morcego brdrusp100/07, sendo completamente sequenciados e alinhados com todas as sequências completas depositadas no GenBank (ANEXO A), que podem ser visualizadas nas figuras 25, 26, 27, 28 (a, b, c), 29 e 30 para a nucleoproteína, 31, 32, 33 (a, b), 34 e 35 para a fosfoproteína, 36, 37, 38 (a, b, c), 39 e 40 para a proteína de matriz, 41, 42, 43 (a, b, c, d), 44 e 45 para a glicoproteína e 47 a $65(\mathrm{a}, \mathrm{b}, \mathrm{c}, \mathrm{d}, \mathrm{e})$ para a polimerase viral.

Segmentos foram obtidos a partir do sequenciamento para as duas amostras estudadas brbvusp01/06 e brdrusp100/07: 1353 nucleotídeos para a nucleoproteína (450 aminoácidos e um códon de terminação), 894 nucleotídeos do gene codificador para fosfoproteína (297 aminoácidos e um códon de terminação), 609 nucleotídeos do gene codificador da proteína de matriz (202 aminoácidos e um códon de terminação), 1575 nucleotídeos correspondentes ao gene codificador para a glicoproteína (524 aminoácidos e um códon de terminação) e fragmentos da polimerase. Os fragmentos descontínuos do gene L para a amostra brbvusp01/06 foram de 801 nucleotídeos (fragmento 1 com 266 aminoácidos, posição 5417 a 6217 da amostra de referência PV, iniciando no primeiro nucleotídeo do códon start da amostra brbvusp01/06), 786 nucletídeos (fragmento 2 com 262 aminoácidos, posição 7202 a 7987 da amostra PV), 864 nucleotídeos (fragmento 3 com 288 aminoácidos, posição 8345 a 9209 da amostra PV) e 2519 nucleotídeos (fragmento 4 com 840 aminoácidos, posição 9369 a 11887 da amostra PV, incluindo o códon de terminação da amostra brbvusp01/06), totalizando $4970(76,3 \%)$ de 6515 nucleotídeos na amostra PV.

Em relação à amostra isolada do morcego brdrusp100/07 foram sequenciados 711 nucleotídeos (fragmento 2a com 236 aminoácidos na posição 7241 a 7951 da amostra PV), 357 nucleotídeos (fragmento 3a com 119 aminoácidos na posição 8765 a 9122 da amostra PV), 801 nucleotídeos (fragmento 4a com 267 aminoácidos na posição 9423 a 10223 da amostra PV), 657 nucleotídeos (fragmento 4b com 219 aminoácidos na posição 10320 a 10977 da amostra PV) e 387 nucleotídeos (fragmento 4c com 129 aminoácidos na posição 11466 a 11852 da amostra PV, incluindo o códon de terminação da amostra brdrusp100/07), o que representa 44,7\% (2913 nucleotídeos) da amostra de referência PV.

A região codificante para nucleoproteína compreende 1353 nucleotídeos (450 aminoácidos e um códon de terminação) na posição 71 a 1424 do genoma viral (referência amostra PV - NC_001542). Nas figuras 26 e 27 pode ser visualizado resultado da análise de toda a região codante da nucleoproteína. Na árvore da figura 26 foram destadacados em 
vermelho o clado onde segregaram todas as amostras pertencentes à variante mantida por morcegos hematófagos D. rotundus (incluindo as amostras deste estudo brbvusp01/06 e brdrusp100/07 também destacadas em vermelho), em azul os dois clados onde se agruparam as amostras do ciclo terrestre de transmissão (inclusive a amostra padrão PV), em azul mais claro o clado onde segregaram as amostras pertencentes à variante mantida pelo morcego insetívoro T. brasiliensis, e dois grandes clados (sem destaque de cor) para as amostras oriundas de morcegos não hematófagos.

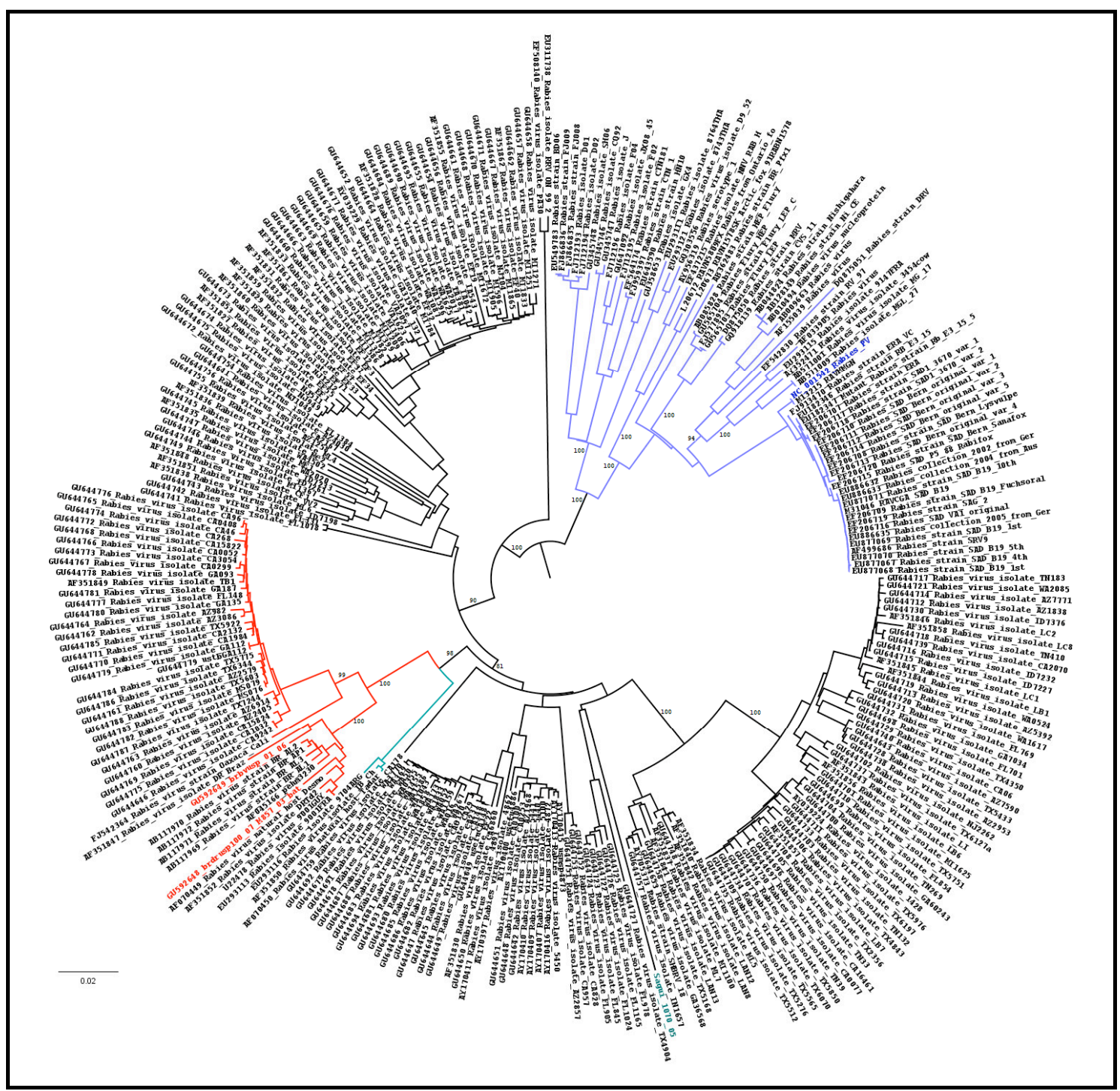

Figura 26. Árvore filogenética de máxima verossimilhança (ML) para nucleoproteína.

Análise (completa), reconstruída pelo programa MEGA4 e realizada uma busca heurística (heuristic search) com o algorítmo "NJ". Os valores nos principais nós representam os valores de 10000 réplicas de bootstrap superiores a $50 \%$. 


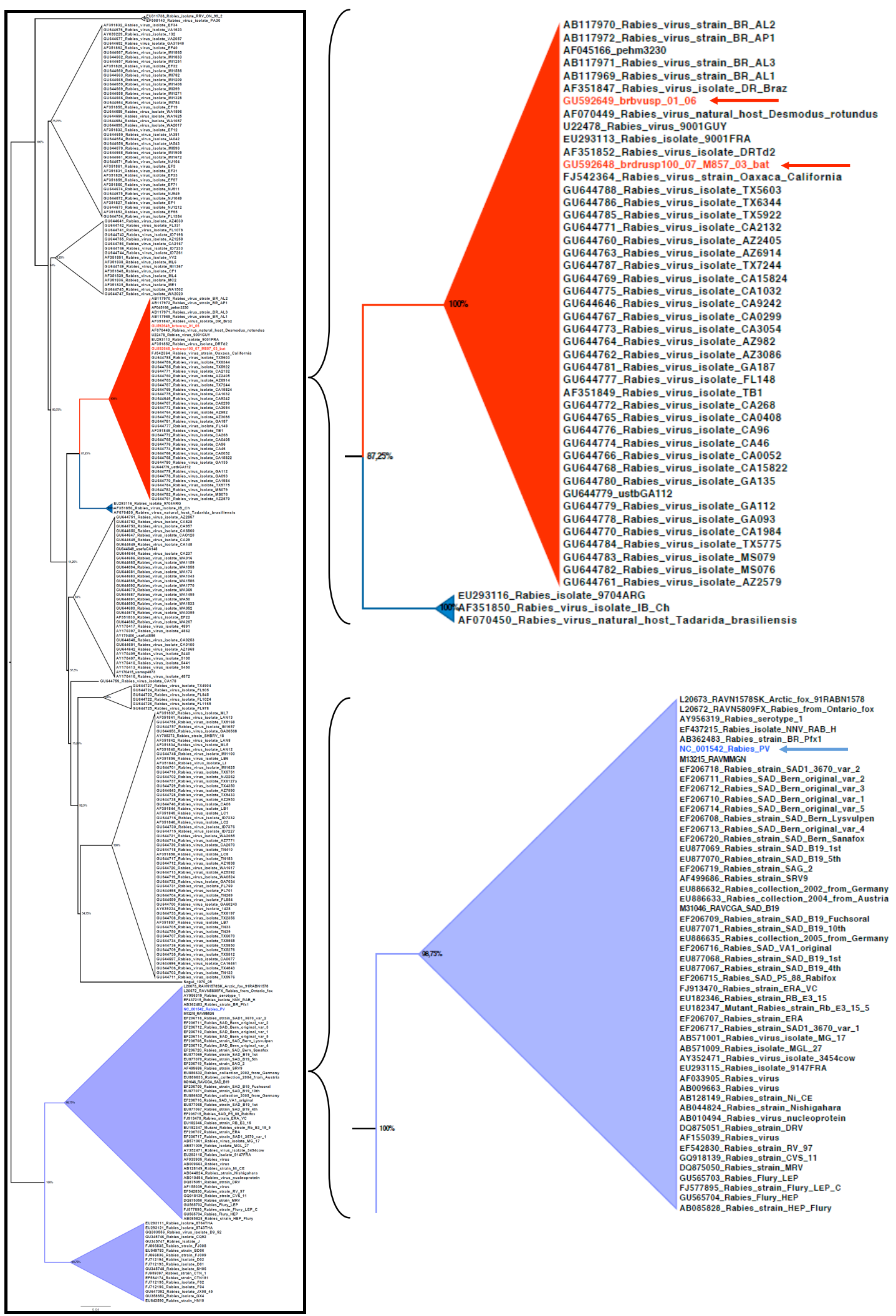

Figura 27. Árvore filogenética de máxima verossimilhança (ML) para nucleoproteína.

Análise (completa), construída pelo programa Garli e realizada uma busca heurística (heuristic search) com o algorítmo "GTR+gama+I". Os valores nos principais nós representam os valores de 1000 réplicas de bootstrap superiores a $50 \%$. 
$\mathrm{Na}$ árvore reconstruída para a nucleoproteína (Figura 27) aparecem destacados em vermelho o clado onde segregaram todas as amostras pertencentes à variante mantida por morcegos hematófagos D. rotundus (incluindo as amostras deste estudo brbvusp01/06 e brdrusp100/07 também destacadas em vermelho), em azul os dois clados onde se agruparam as amostras do ciclo terrestre de transmissão (inclusive a amostra padrão PV), em azul mais escuro o clado onde segregaram as amostras pertencentes à variante mantida pelo morcego insetívoro T. brasiliensis, cinco clados (sem destaque de cor) para as amostras oriundas de morcegos não hematófagos e uma amostra de morcego não hematófago GU644759 segregou isoladamente, além da amostra proveniente de um sagui que também segregou no ciclo aéreo de transmissão.

Com a análise dos aminoácidos da proteína $\mathrm{N}$ (Tabela 3) foi possível observar 21 substituições de aminoácidos quando as amostras brbvusp01/06 e brdrusp100/07 foram comparadas à amostra de referência PV (NC_001542). Nove substituições foram do tipo não conservativa para a amostra brbvusp01/06 (bovino) e dez para a amostra brdrusp100/07 (morcego).

Tabela 3 - Substituições de aminoácidos encontradas para a proteína $\mathbf{N}$

\begin{tabular}{|c|c|c|c|c|}
\hline Resíduo & brdrusp100/07 & brbvusp01/06 & PV-NC_001542 & Tipo de substituição \\
\hline 40 & Serina & Serina & Cisteína & Não Conservativa \\
\hline 50 & Histidina & Serina & Asparagina & Não Conservativa / Conservativa \\
\hline 56 & Isoleucina & Isoleucina & Valina & Conservativa \\
\hline 59 & Glicina & Glicina & Cisteína & Conservativa \\
\hline 61 & Asparagina & Asparagina & Serina & Conservativa \\
\hline 84 & Serina & Serina & Treonina & Conservativa \\
\hline 95 & Leucina & Leucina & Valina & Conservativa \\
\hline 106 & Asparagina & Ácido Aspartico & Glicina & Não Conservativa/Não Conservativa \\
\hline 110 & Ácido Aspartico & Ácido Aspartico & Ácido Glutâmico & Conservativa \\
\hline 112 & Arginina & Arginina & Lisina & Conservativa \\
\hline 135 & Serina & Serina & Prolina & Não Conservativa \\
\hline 157 & Asparagina & Asparagina & Serina & Conservativa \\
\hline 179 & Alanina & Alanina & Valina & Conservativa \\
\hline 257 & Leucina & Leucina & Isoleucina & Conservativa \\
\hline 332 & Treonina & Treonina & Alanina & Não Conservativa \\
\hline 377 & Alanina & Alanina & Treonina & Não Conservativa \\
\hline 378 & Ácido Glutâmico & Ácido Glutâmico & Treonina & Não Conservativa \\
\hline 379 & Treonina & Treonina & Valina & Não Conservativa \\
\hline 397 & Serina & Serina & Ácido Glutâmico & Não Conservativa \\
\hline 410 & Metionina & Metionina & Isoleucina & Conservativa \\
\hline 433 & Treonina & Treonina & Alanina & Não Conservativa \\
\hline
\end{tabular}

As figuras 28a (resíduo 377), 28b (resíduo 397) e 28c (resíduo 433) mostram três sítios da nucleoproteína onde ocorreu a substituição de aminoácidos da variante mantida por morcegos hematófagos $D$. rotundus quando comparadas as outras sequências de diferentes variantes. As figuras foram obtidas pela análise dos dados pelo programa MacClade (Maddison e Maddison, 2000). 


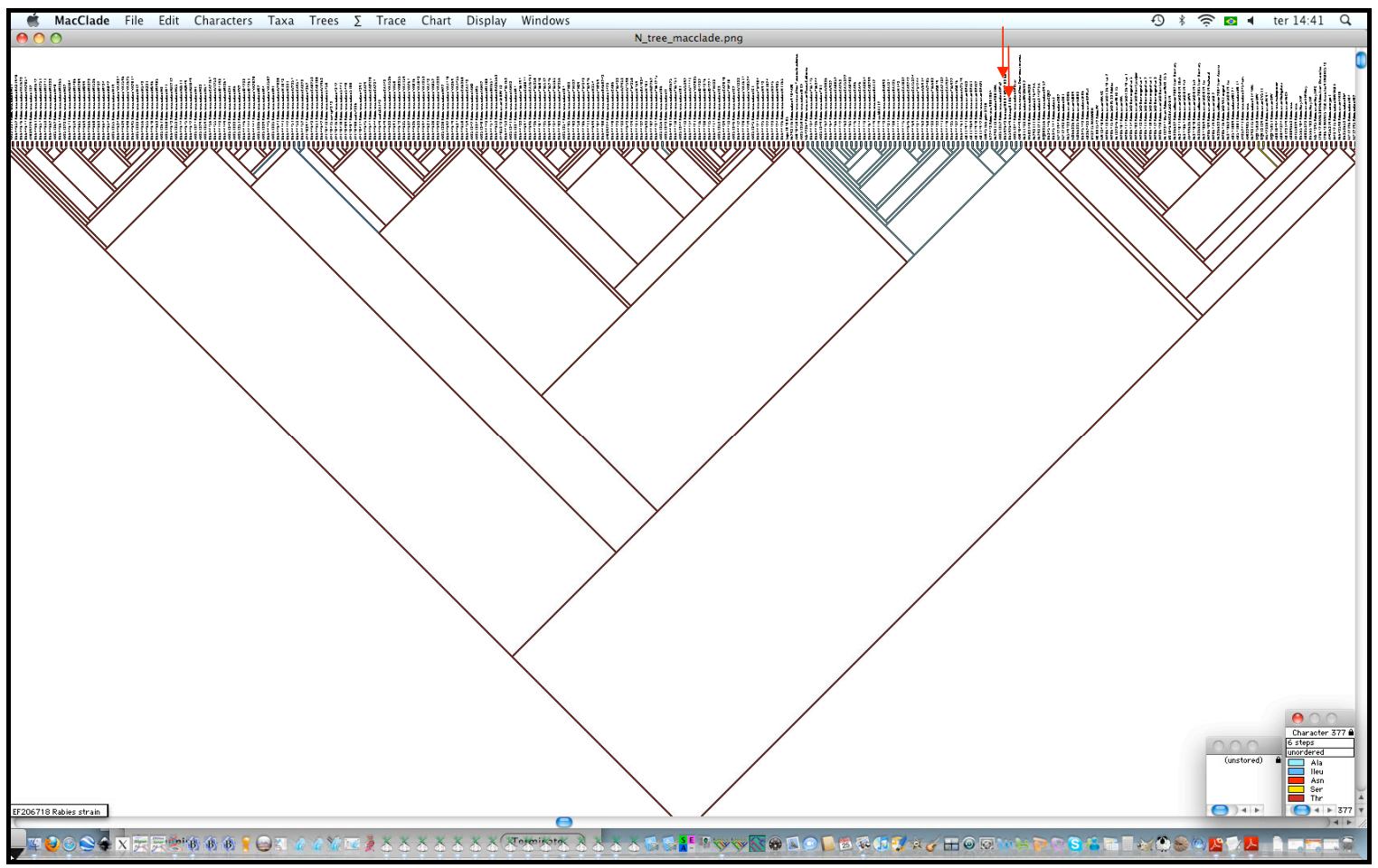

Figura 28a. Ilustração gerada pelo programa MacClade para o resíduo 377 da nucleoproteína.

Em azul pode ser vista a Alanina conservada para as amostras brbvusp01/06, brdrusp100/07 e demais amostras da variante mantida pelo morcego hematófago.

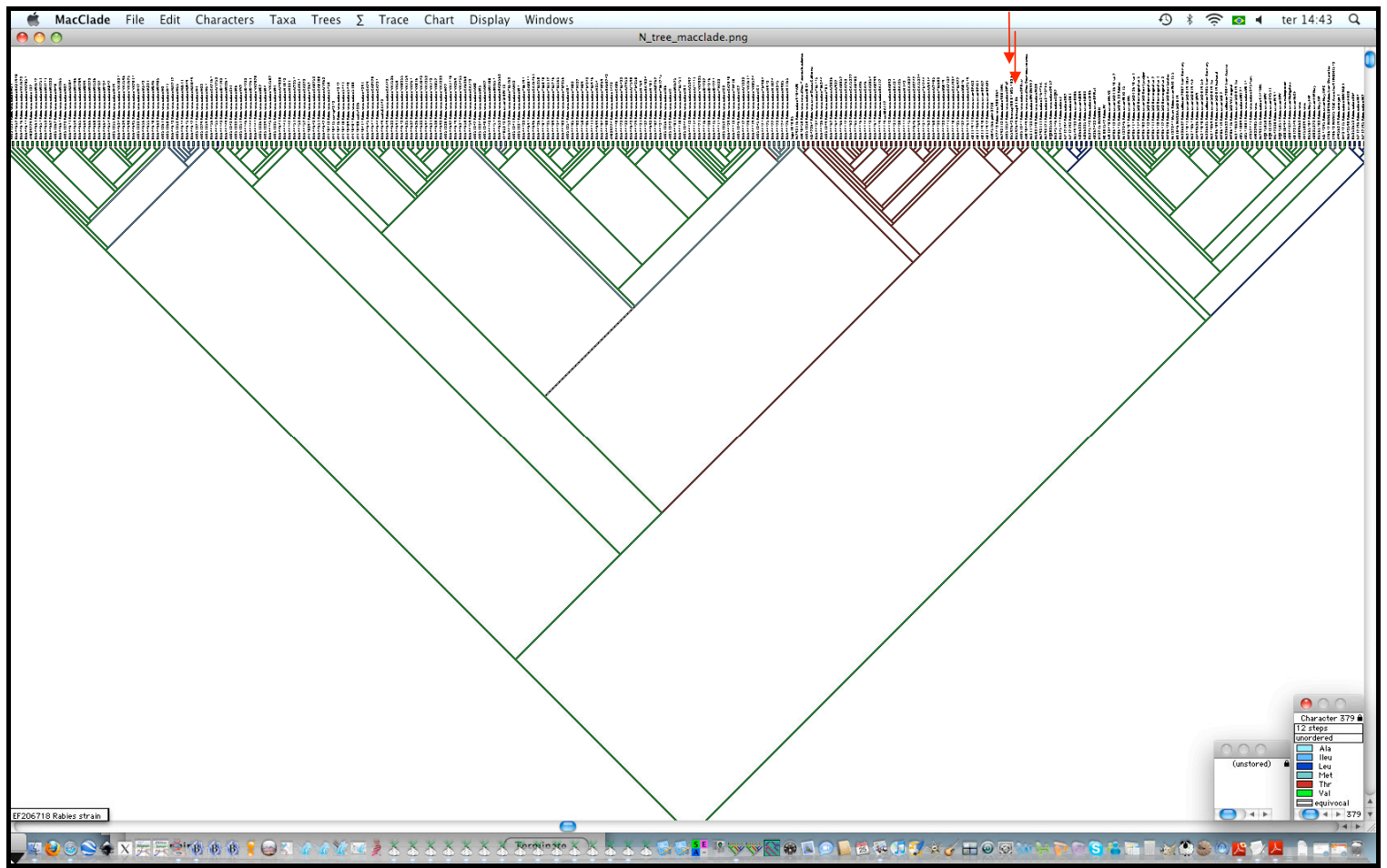

Figura 28b. Ilustração gerada pelo programa MacClade para o resíduo 379 da nucleoproteína.

Em marrom pode ser vista a Treonina conservada para as amostras brbvusp01/06, brdrusp100/07 e demais amostras da variante mantida pelo morcego hematófago. 


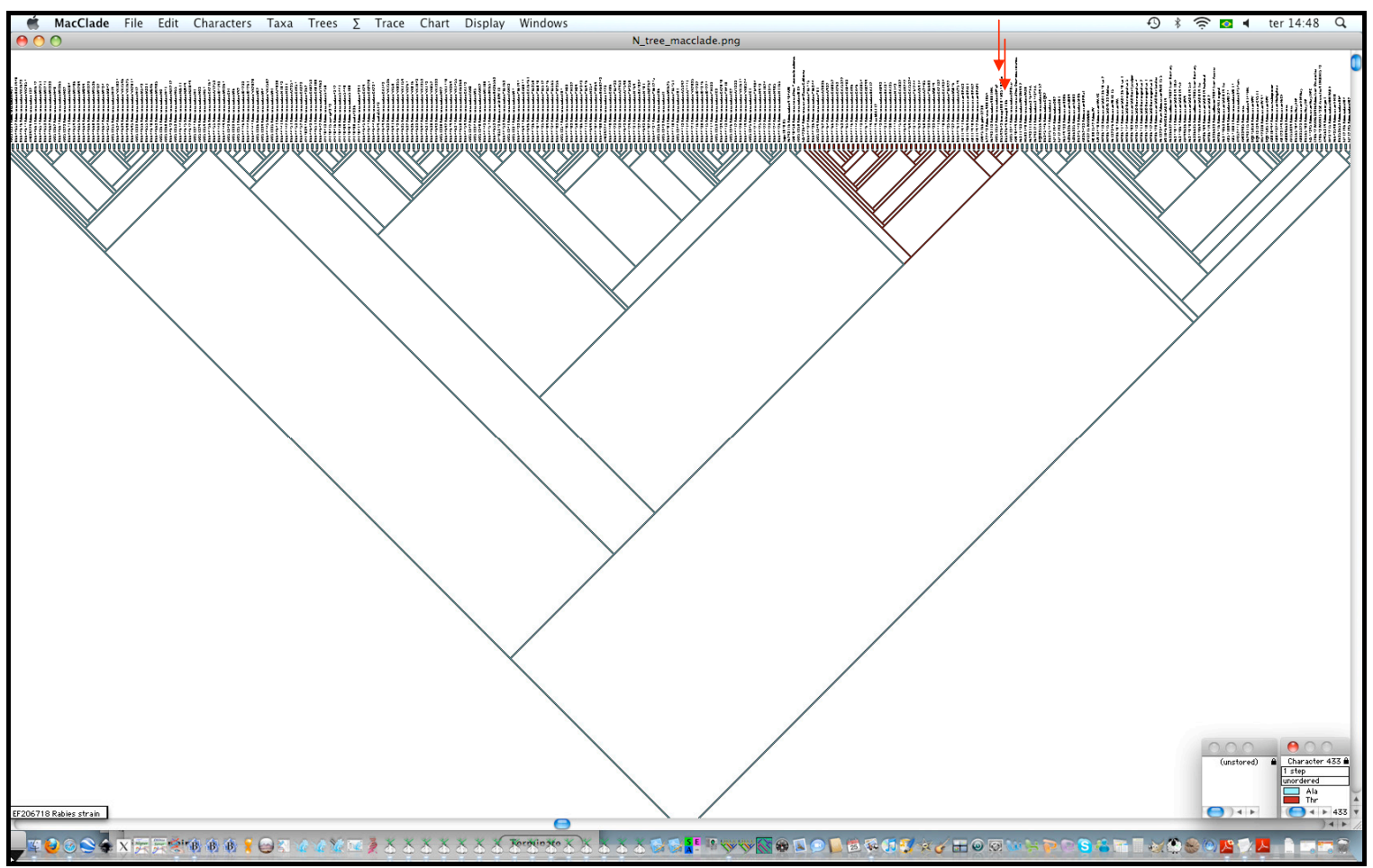

Figura 28c. Ilustração gerada pelo programa MacClade para o resíduo 433 da nucleoproteína.

A Treonina conservada pode ser vista para as amostras brbvusp01/06, brdrusp100/07 e demais amostras da variante mantida pelo morcego hematófago.

A figura 29 obtida pela análise das sequencias de nucleotídeos pelo programa MacClade (Maddison e Maddison, 2000) mostra a frequência geral de aminoácidos considerando todas as sequências utilizadas para a reconstrução da árvore filogenética. $\mathrm{O}$ aminoácido mais frequente foi a Serina e o menos frequente foi o Triptofano. A figura 30 indica as mudanças de aminoácidos em todos os sítios da nucleoproteína, análise dos dados pelo programa MacClade (Maddison e Maddison, 2000), onde pode ser observado que as maiores taxas de mudanças aconteceram do aminoácido Lisina (K) para Arginina (R), Treonina (T) para Alanina (A) e Valina (V) para Isoleucina (I). 


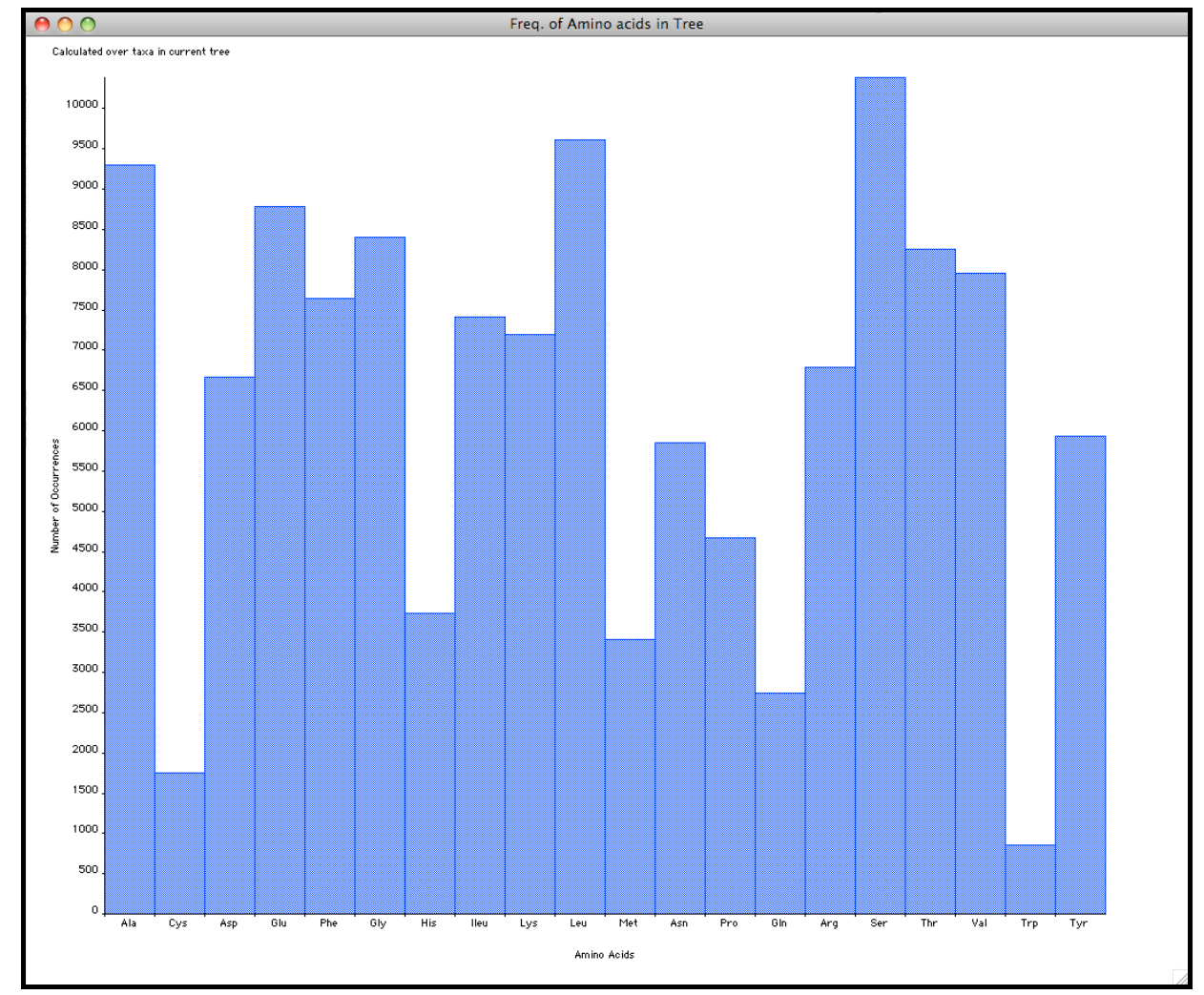

Figura 29. Gráfico com frequência de aminoácidos na nucleoproteína.

Análise para todas as sequências utilizadas na reconstrução da árvore

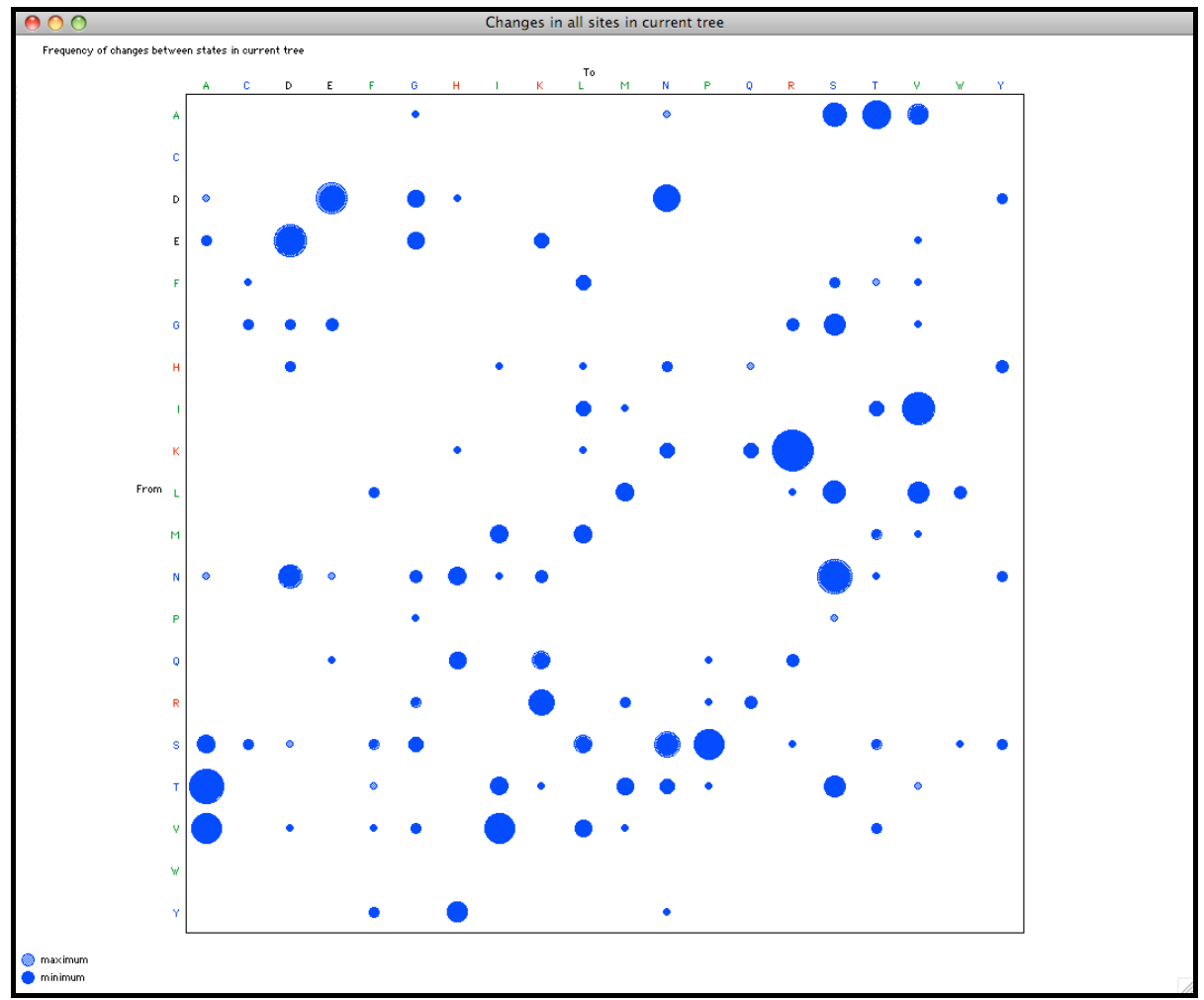

Figura 30. Gráfico de substituição de aminoácidos na nucleoproteína.

Análise para todas as sequências utilizadas na reconstrução da árvore 
A região codificante para fosfoproteína compreende 894 nucleotídeos (297 aminoácidos e um códon de terminação) na posição 1514 a 2407 do genoma. Com a análise dos aminoácidos da proteína $\mathrm{P}$ (Tabela 4) foi possível observar um grande número de substituições de aminoácidos, 52 substituições quando a amostra brbvusp01/06 foi comparada à amostra de referência PV (NC_001542) e 51 quando a amostra brdrusp100/07 foi comparada ao padrão.

Tabela 4- Substituições de aminoácidos encontradas para a proteína $P$

\begin{tabular}{|c|c|c|c|c|}
\hline Resíduo & brdrusp100/07 & brbvusp01/06 & PV-NC_001542 & Tipo de substituição \\
\hline 29 & Alanina & Alanina & Asparagina & Não Conservativa \\
\hline 42 & Ácido Aspartico & Ácido Aspártico & Ácido Glutâmico & Conservativa \\
\hline 48 & Serina & Serina & Asparagina & Conservativa \\
\hline 54 & Arginina & Arginina & Glicina & Não Conservativa \\
\hline 57 & Glutamina & Glutamina & Histidina & Não Conservativa \\
\hline 61 & Ácido Aspartico & Ácido Aspartico & Glicina & Não Conservativa \\
\hline 65 & Glicina & Glicina & Asparagina & Conservativa \\
\hline 66 & Leucina & Prolina & Prolina & Não Conservativa \\
\hline 68 & Serina & Serina & Ácido Glutâmico & Não Conservativa \\
\hline 69 & Treonina & Treonina & Metionina & Não Conservativa \\
\hline 72 & Alanina & Alanina & Valina & Conservativa \\
\hline 86 & Alanina & Alanina & Glicina & Não Conservativa \\
\hline 90 & Alanina & Alanina & Serina & Não Conservativa \\
\hline 102 & Isoleucina & Isoleucina & Valina & Conservativa \\
\hline 108 & Metionina & Metionina & Isoleucina & Conservativa \\
\hline 109 & Lisina & Lisina & Arginina & Conservativa \\
\hline 112 & Glicina & Glicina & Ácido Glutâmico & Não Conservativa \\
\hline 126 & Isoleucina & Valina & Isoleucina & Conservativa \\
\hline 130 & Treonina & Treonina & Alanina & Não Conservativa \\
\hline 134 & Serina & Serina & Prolina & Não Conservativa \\
\hline 135 & Glicina & Glicina & Asparagina & Conservativa \\
\hline 136 & Alanina & Alanina & Prolina & Conservativa \\
\hline 159 & Serina & Serina & Prolina & Não Conservativa \\
\hline 160 & Alanina & Alanina & Treonina & Não Conservativa \\
\hline 161 & Serina & Serina & Prolina & Não Conservativa \\
\hline 165 & Alanina & Alanina & Ácido Glutâmico & Não Conservativa \\
\hline 168 & Prolina & Prolina & Serina & Não Conservativa \\
\hline 171 & Alanina & Valina & Alanina & Conservativa \\
\hline 172 & Lisina & Lisina & Arginina & Conservativa \\
\hline 178 & Valina & Valina & Alanina & Conservativa \\
\hline 188 & Valina & Valina & Alanina & Conservativa \\
\hline 189 & Alanina & Alanina & Treonina & Não Conservativa \\
\hline 195 & Prolina & Prolina & Leucina & Conservativa \\
\hline 223 & Fenilalanina & Fenilalanina & Leucina & Conservativa \\
\hline 241 & Serina & Serina & Alanina & Não Conservativa \\
\hline 252 & Histidina & Histidina & Arginina & Conservativa \\
\hline 280 & Prolina & Prolina & Serina & Não Conservativa \\
\hline 281 & Ácido Aspártico & Ácido Aspartico & Asparagina & Não Conservativa \\
\hline 284 & Asparagina & Asparagina & Serina & Conservativa \\
\hline 295 & Alanina & Alanina & Treonina & Não Conservativa \\
\hline 297 & Prolina & Prolina & Cisteína & Não Conservativa \\
\hline
\end{tabular}


As amostras estudadas apresentaram 29 substituições não conservativas em comum quando foram comparadas ao padrão além de duas substituições não conservativas apenas na amostra brbvusp01/06 e outras duas substituições não conservativas para a amostra brdrusp100/07.

A figura 31 mostra em azul o ciclo terrestre de transmissão com a amostra referência PV em evidência e em vermelho aparecem as amostras da variante mantida por morcegos hematófagos. As amostras deste estudo brbvusp01/06 e brdrusp100/07 estão salientadas em vermelho.

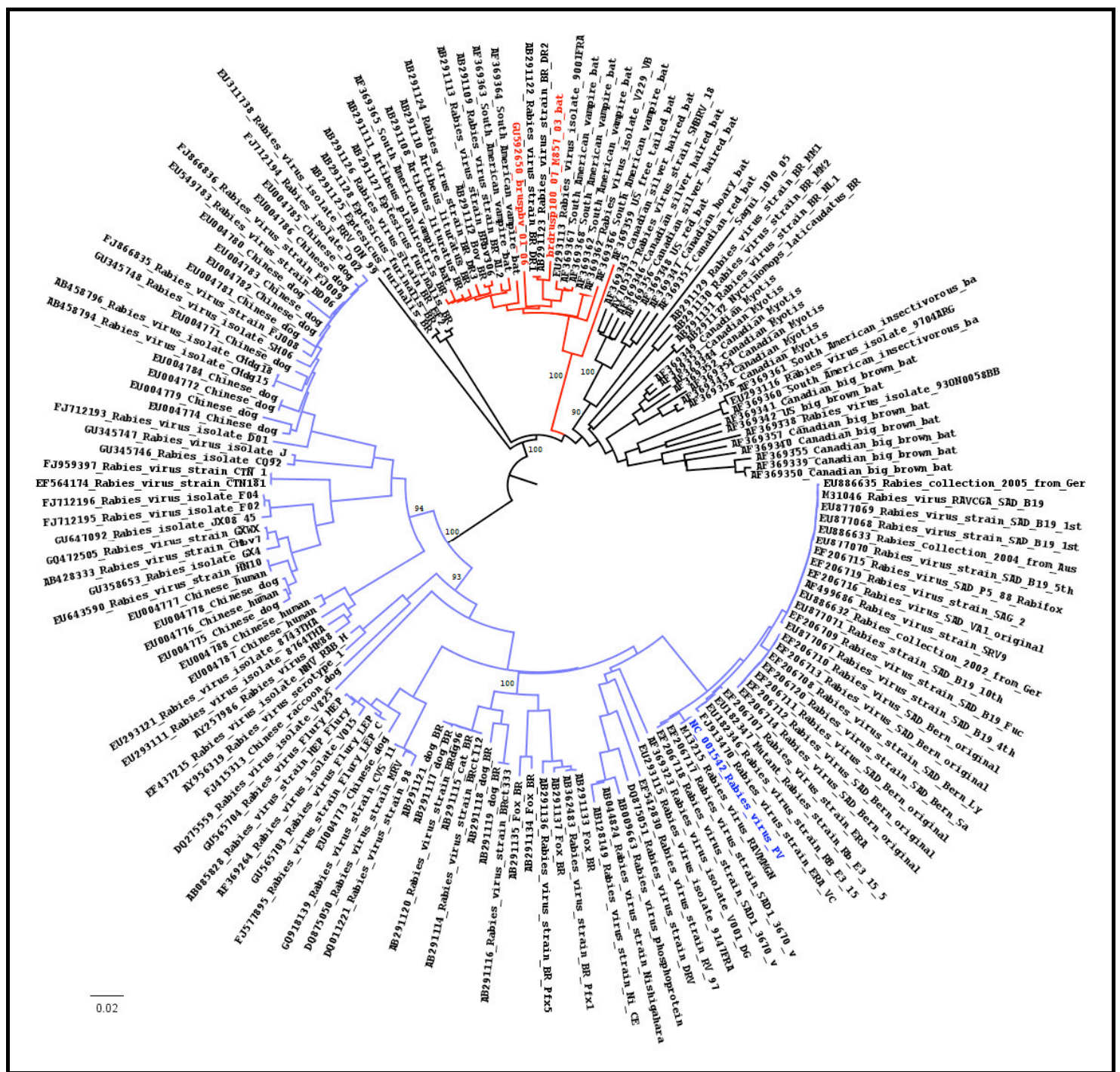

Figura 31. Árvore filogenética de máxima verossimilhança (ML) para a fosfoproteína.

Reconstruída pelo programa MEGA 4.0 e realizada uma busca heurística (heuristic search) com o algorítmo "NJ". Os valores nos principais nós representam os valores de 10000 réplicas de bootstrap superiores a $50 \%$.

A figura 32 é uma árvore de máxima verossimilhança, realizada pelo programa GARLi, onde as amostras relacionadas ao morcego hematófago D. rotundus aparecem destacadas em vermelho e o ciclo terrestre de transmissão aparece em azul. 


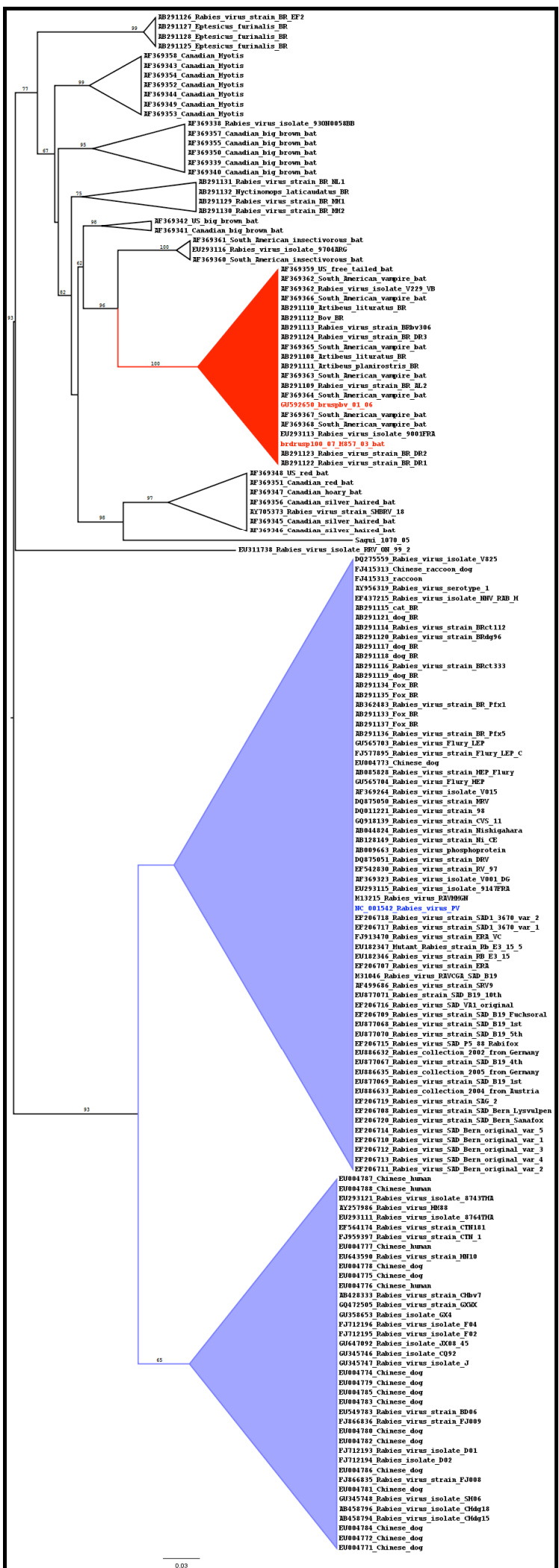

Figura 32. Árvore filogenética de máxima verossimilhança (ML) para a fosfoproteína.

Reconstruída pelo programa GARLi e realizada uma busca heurística (heuristic search) com o algorítmo "GTR+gama+I". Os valores nos principais nós representam os valores de 1000 réplicas de bootstrap superiores a $50 \%$. 


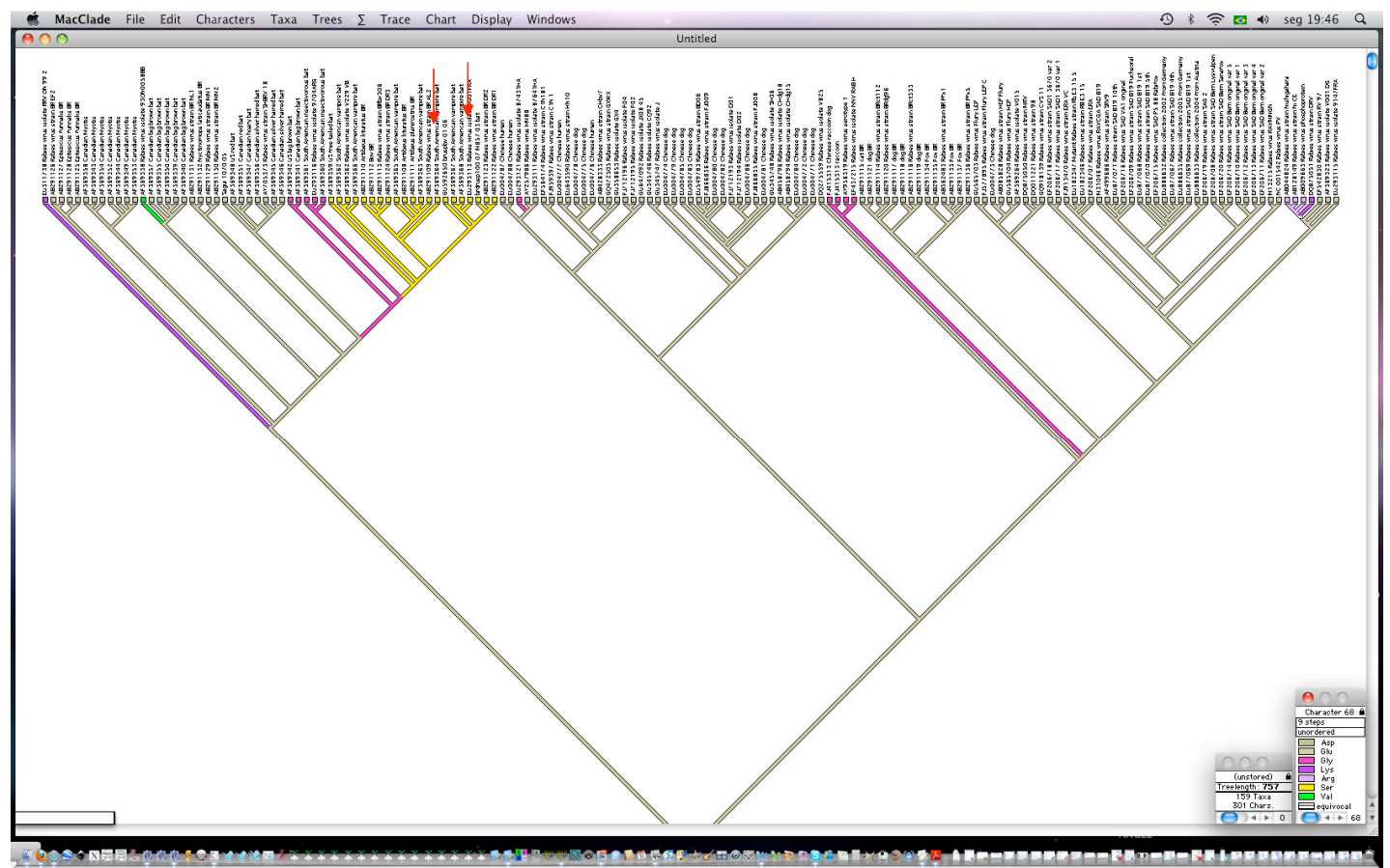

Figura 33a. Ilustração gerada pelo programa MacClade para o resíduo 68 da fosfoproteína. Em amarelo pode ser vista a Serina conservada para a variante mantida por morcegos hematófagos as setas vermelhas indicam as amostras brbvusp01/06 e brdrusp100/07.

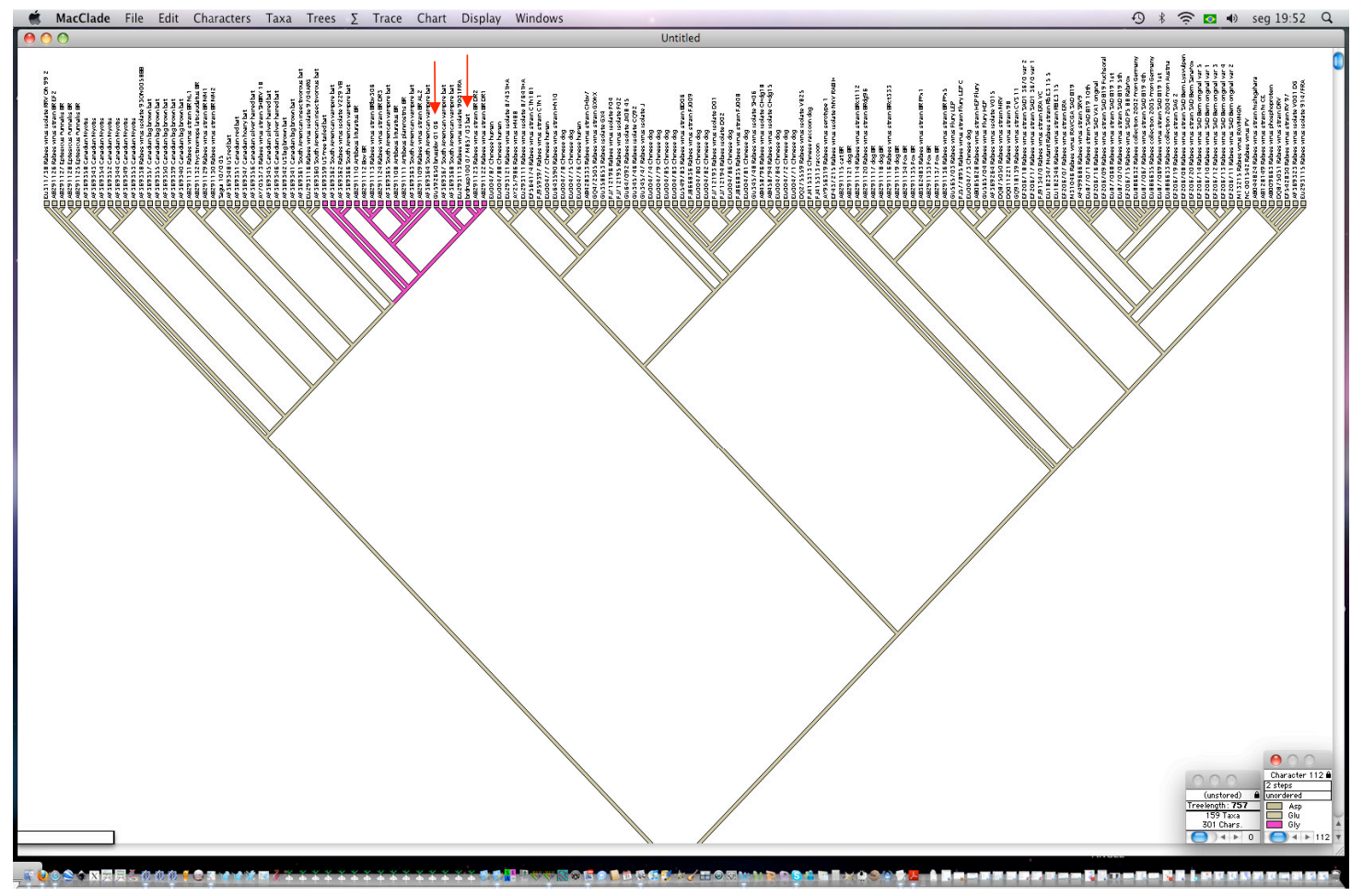

Figura 33b. Ilustração gerada pelo programa MacClade para o resíduo 112 da fosfoproteína.

Em rosa pode ser vista a Glicina conservada para a variante mantida por morcegos hematófagos as setas vermelhas indicam as amostras brbvusp01/06 e brdr100/07.

As figuras 33a e 33b demonstram dois dos três resíduos de aminoácidos específicos para a variante mantida por morcegos hematófagos D. rotundus. O resíduo 61 com uma 
Asparagina é primeiro próprio da variante do morcego hematófago. Na figura 33a aparece o resíduo 68 com a Serina e na figura 33b o resíduo 112 com a Glicina.

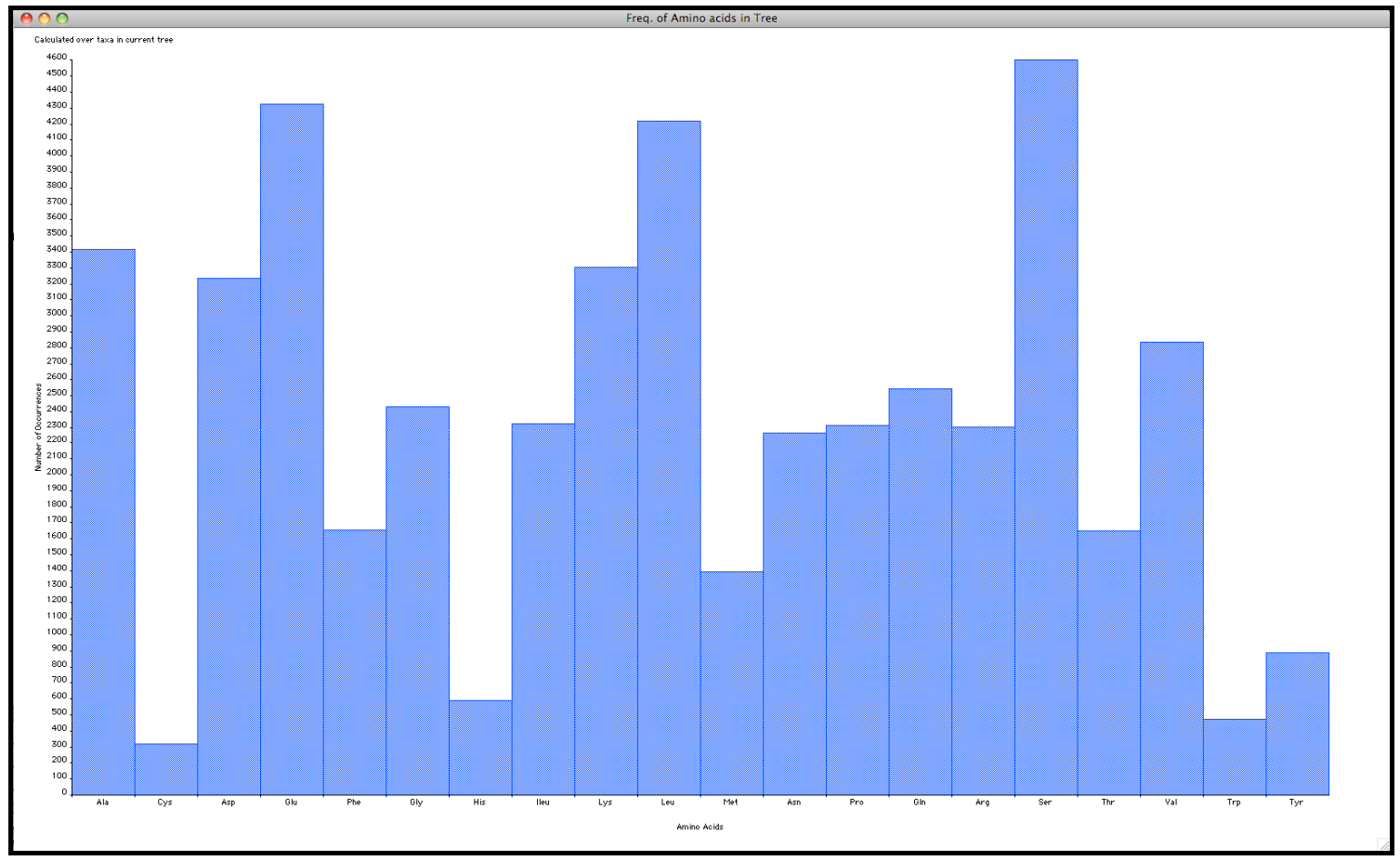

Figura 34. Gráfico com frequência de aminoácidos na fosfoproteína.

Análise para todas as sequências utilizadas na reconstrução da árvore.

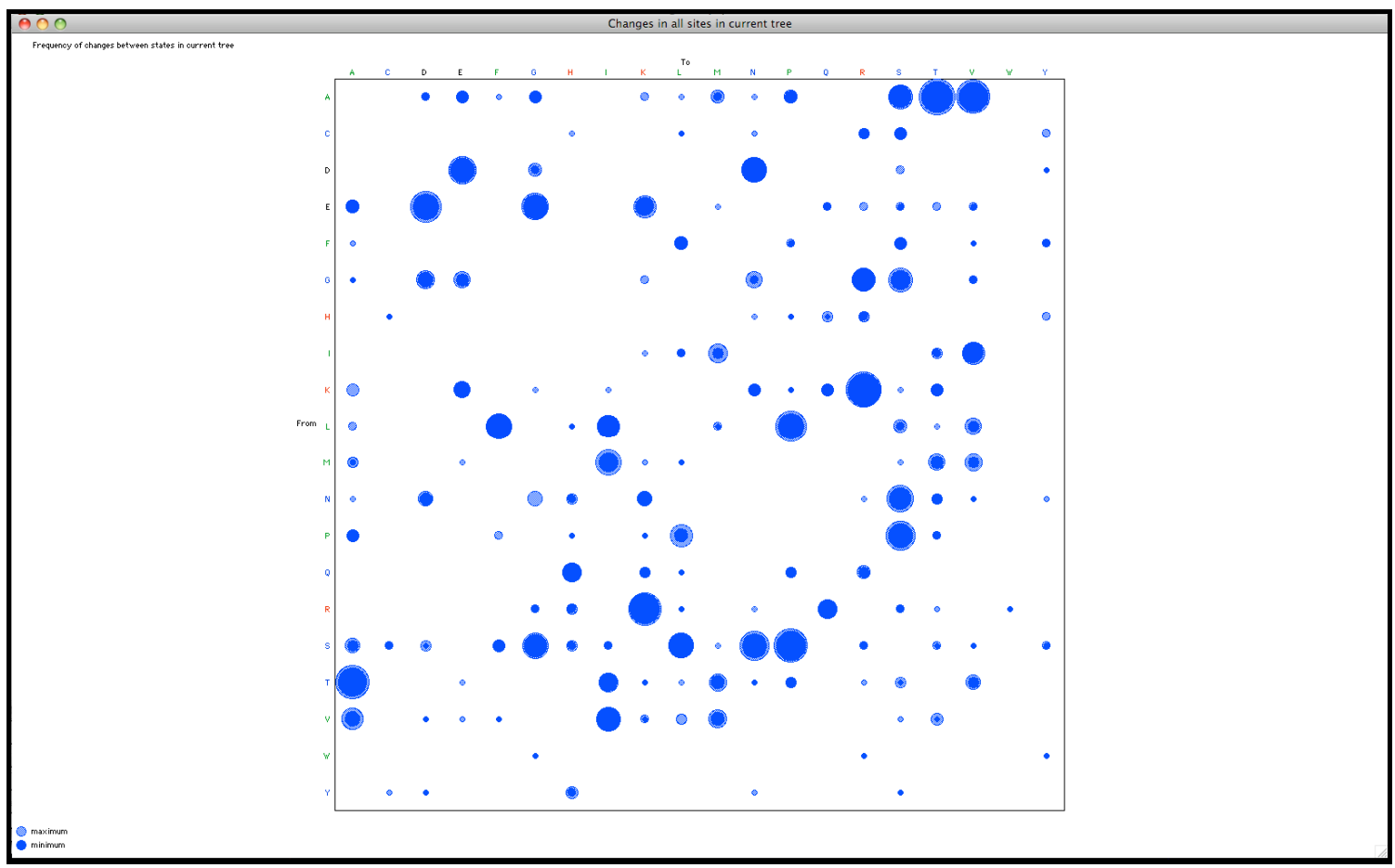

Figura 35. Gráfico de substituição de aminoácidos na fosfoproteína.

Análise para todas as sequências utilizadas na reconstrução da árvore. 
A figura 34 mostra a frequência geral de aminoácidos para a fosfoproteína sendo o mais frequente a Serina e o menos frequente a Cisteína. A figura 35 indica as taxas de mudanças de aminoácidos na fosfoproteína, onde pode ser observado que as maiores taxas de mudanças aconteceram do aminoácido Asparagina $(\mathrm{N})$ para Glicina $(\mathrm{G})$, Lisina $(\mathrm{K})$ para Alanina (A) e Valina (V) para Leucina (L).

A proteína de matriz (M) apresentou uma região de 609 nucleotídeos compreendidos entre a posição 2496 e a posição 3104 do genoma viral que codifica 202 aminoácidos e um códon de terminação) na posição 2496 a 3104 do genoma.

Na figura 36 em azul aparece o ciclo terrestre de transmissão e em vermelho o clado representante da variante mantida por morcegos hematófagos.

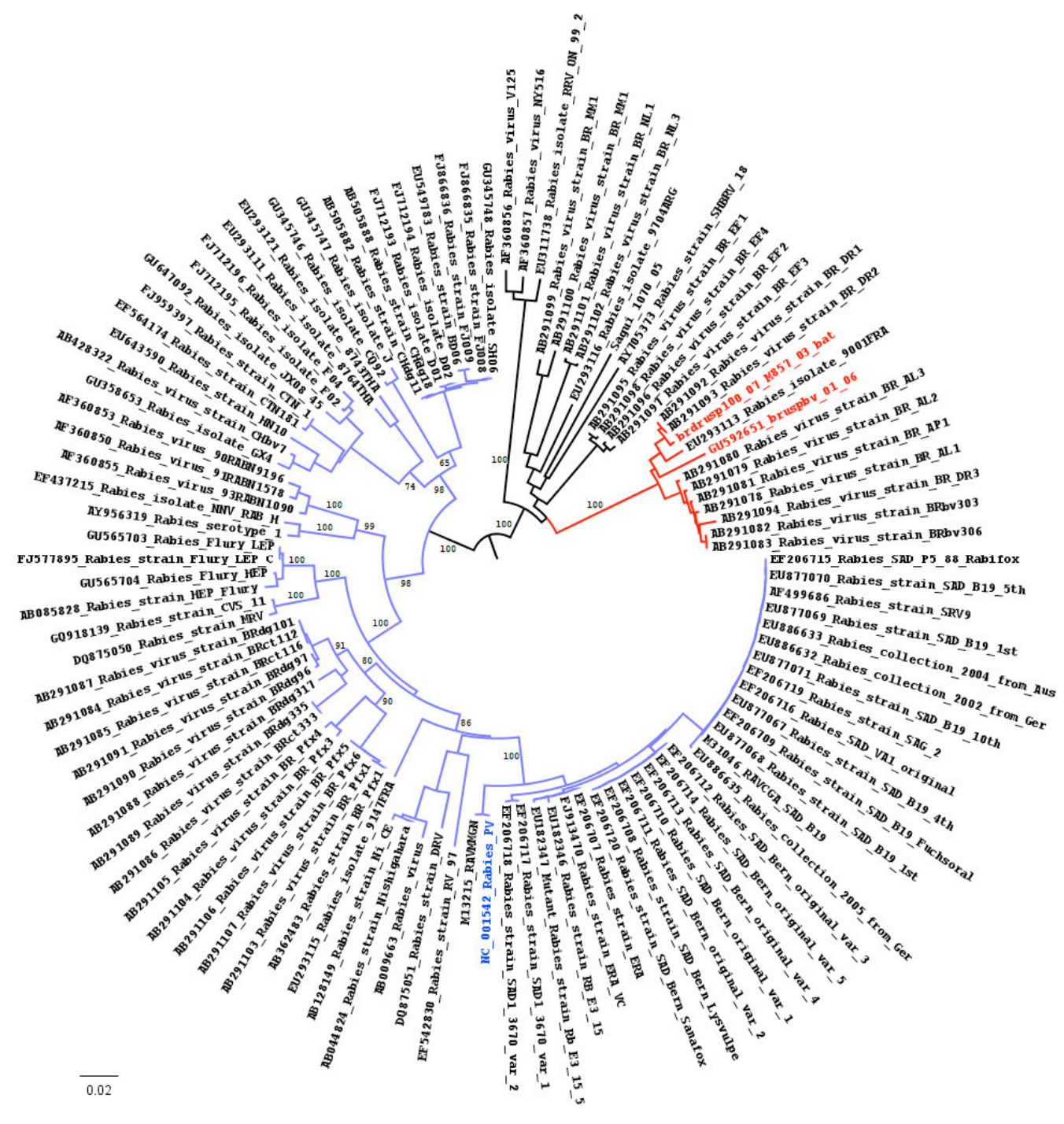

Figura 36. Árvore filogenética de máxima verossimilhança (ML) para proteína de matriz.

Reconstruída pelo programa MEGA4 e realizada uma busca heurística (heuristic search) com o algorítmo "NJ". Os valores nos principais nós representam os valores de 10000 réplicas de bootstrap superiores a $50 \%$. 


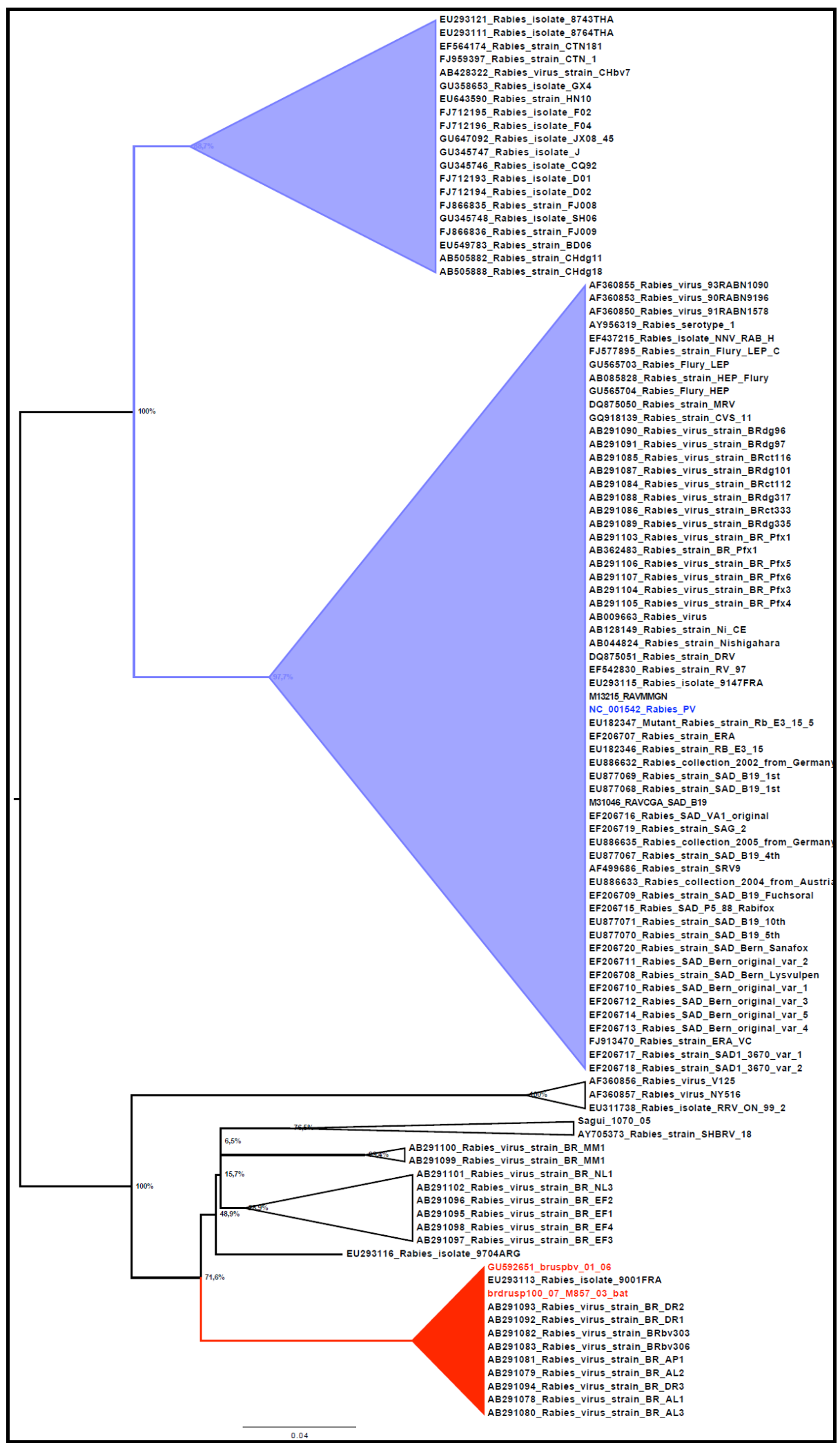

Figura 37. Árvore filogenética de máxima verossimilhança (ML) para proteína de matriz.

Reconstruída pelo programa Garli e realizada uma busca heurística (heuristic search) com o algorítmo "GTR+gama+I". Os valores nos principais nós representam os valores de 1000 réplicas de bootstrap superiores a $50 \%$. 
Na figura $37 \mathrm{em}$ vermelho aparecem as amostras relacionadas à variante mantida por morcegos hematófagos e em azul as amostras relacionadas ao ciclo terrestre de transmissão para a proteína de matriz.

Com a análise dos aminoácidos da proteína de matriz (Tabela 5) foi possível as substituições de aminoácidos, 26 substituições sendo oito delas não conservativas para a amostra brdrusp100/07 e dez para amostra brbvusp01/06 quando comparadas à amostra de referência PV (NC_001542).

Tabela 5 - Substituições de aminoácidos encontradas para a proteína $M$

\begin{tabular}{|c|c|c|c|c|}
\hline Resíduo & brdrusp100/07 & brbvusp01/06 & PV-NC_001542 & Tipo de substituição \\
\hline 7 & Metionina & Metionina & Isoleucina & Conservativa \\
\hline 21 & Leucina & Leucina & Prolina & Conservativa \\
\hline 26 & Prolina & Prolina & Leucina & Conservativa \\
\hline 46 & Glicina & Glicina & Serina & Conservativa \\
\hline 50 & Metionina & Metionina & Arginina & Não Conservativa \\
\hline 70 & Arginina & Arginina & Glicina & Não Conservativa \\
\hline 80 & Asparagina & Asparagina & Ácido Aspártico & Não Conservativa \\
\hline 82 & Leucina & Leucina & Isoleucina & Conservativa \\
\hline 87 & Glutamina & Ácido Glutâmico & Histidina & Não Conservativa \\
\hline 90 & Isoleucina & Isoleucina & Valina & Conservativa \\
\hline 110 & Metionina & Leucina & Metionina & Conservativa \\
\hline 126 & Ácido Aspártico & Glicina & Ácido Aspártico & Não Conservativa \\
\hline 147 & Ácido Aspártico & Ácido Aspártico & Asparagina & Não Conservativa \\
\hline 148 & Alanina & Alanina & Treonina & Conservativa \\
\hline 154 & Ácido Glutâmico & Ácido Glutâmico & Ácido Glutâmico & Não Conservativa \\
\hline 160 & Lisina & Lisina & Arginina & Conservativa \\
\hline 165 & Glutamina & Ácido Glutâmico & Arginina & Não Conservativa \\
\hline 178 & Cisteína & Cisteína & Glicina & Conservativa \\
\hline 184 & Leucina & Leucina & Metionina & Conservativa \\
\hline 192 & Ácido Aspártico & Ácido Aspártico & Ácido Glutâmico & Conservativa \\
\hline
\end{tabular}

As figuras 38a e 38b e 38c, logo a seguir, são exemplos da visualização dos dados pelo MacClade (Maddison e Maddison, 2000) para a proteína de matriz e nelas podem ser vistas três das substituições próprias para a variante genética mantida por morcegos hematófagos $D$. rotundus no aminoácido 82, 148 e no aminoácido 184 respectivamente além do resíduo 192 que nesta variane apresenta um Ácido Aspártico enquanto a amostra PV apresenta um Ácido Glutâmico. 


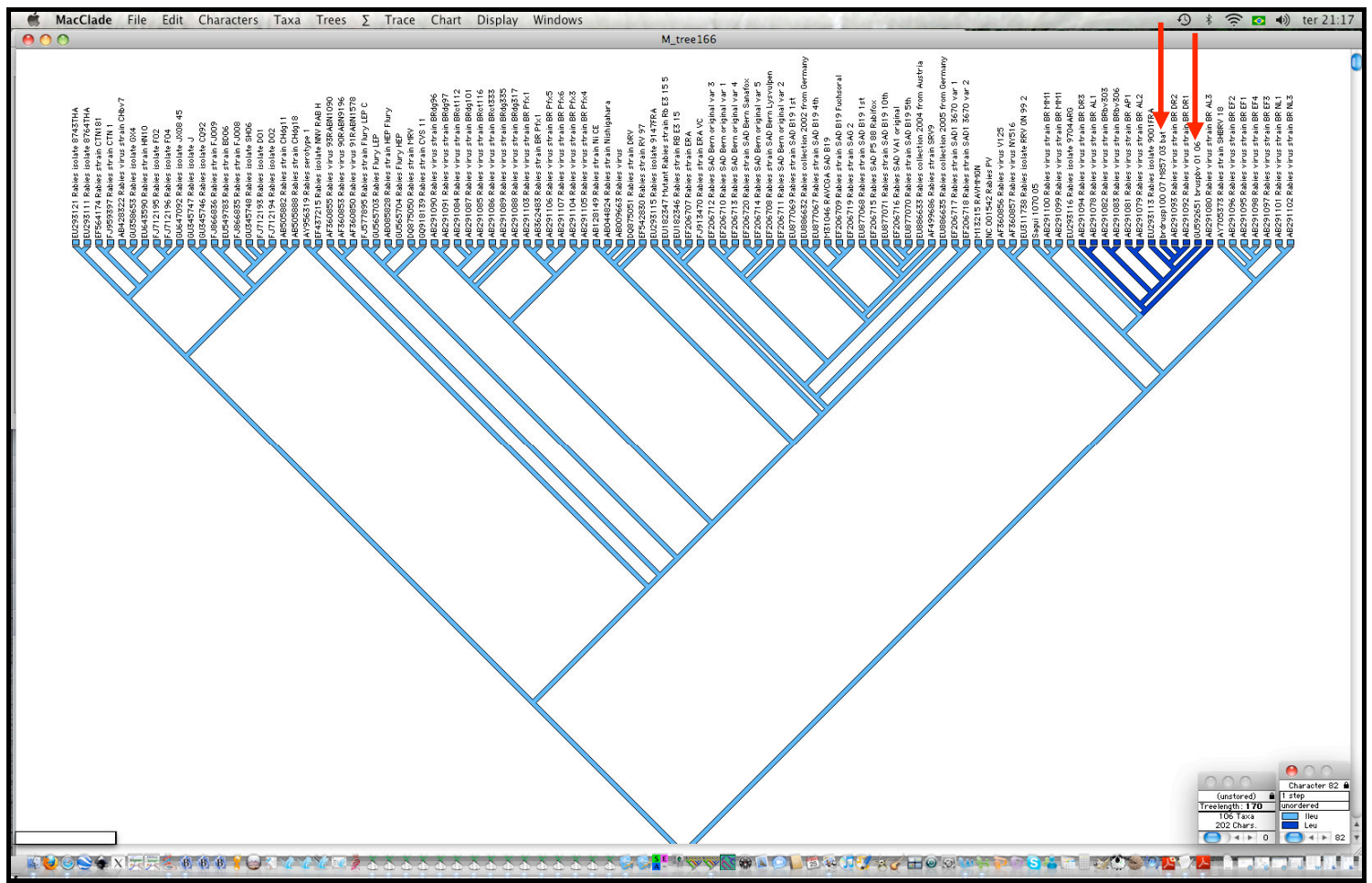

Figura 38a. Ilustração gerada pelo programa MacClade para o resíduo 82 da proteína de matriz.

Em azul escuro pode ser visao a Leucina para as amostras com variante genética mantida por morcegos hematófagos Desmodus rotundus entre elas as amostras brbvusp01/06 e brdrusp100/07.

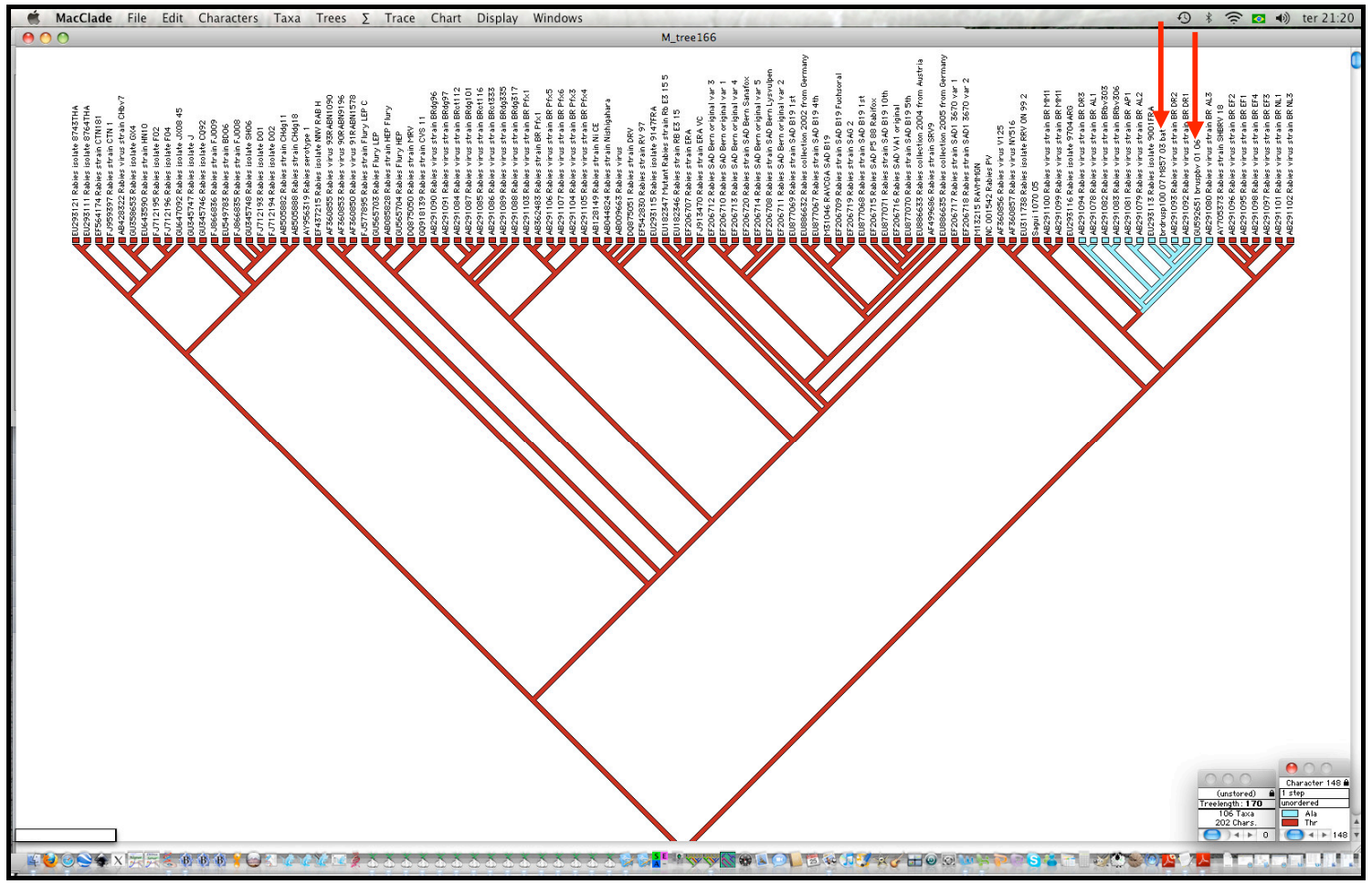

Figura 38b.Ilustração gerada pelo programa MacClade para o resíduo 148 da proteína de matriz.

Em azul claro pode ser vista a Isoleucina para as amostras com variante genética mantida por morcegos hematófagos Desmodus rotundus entre elas as amostras brbvusp01/06 e brdrusp100/07, e a Treonina para as demais amostras analisadas. 


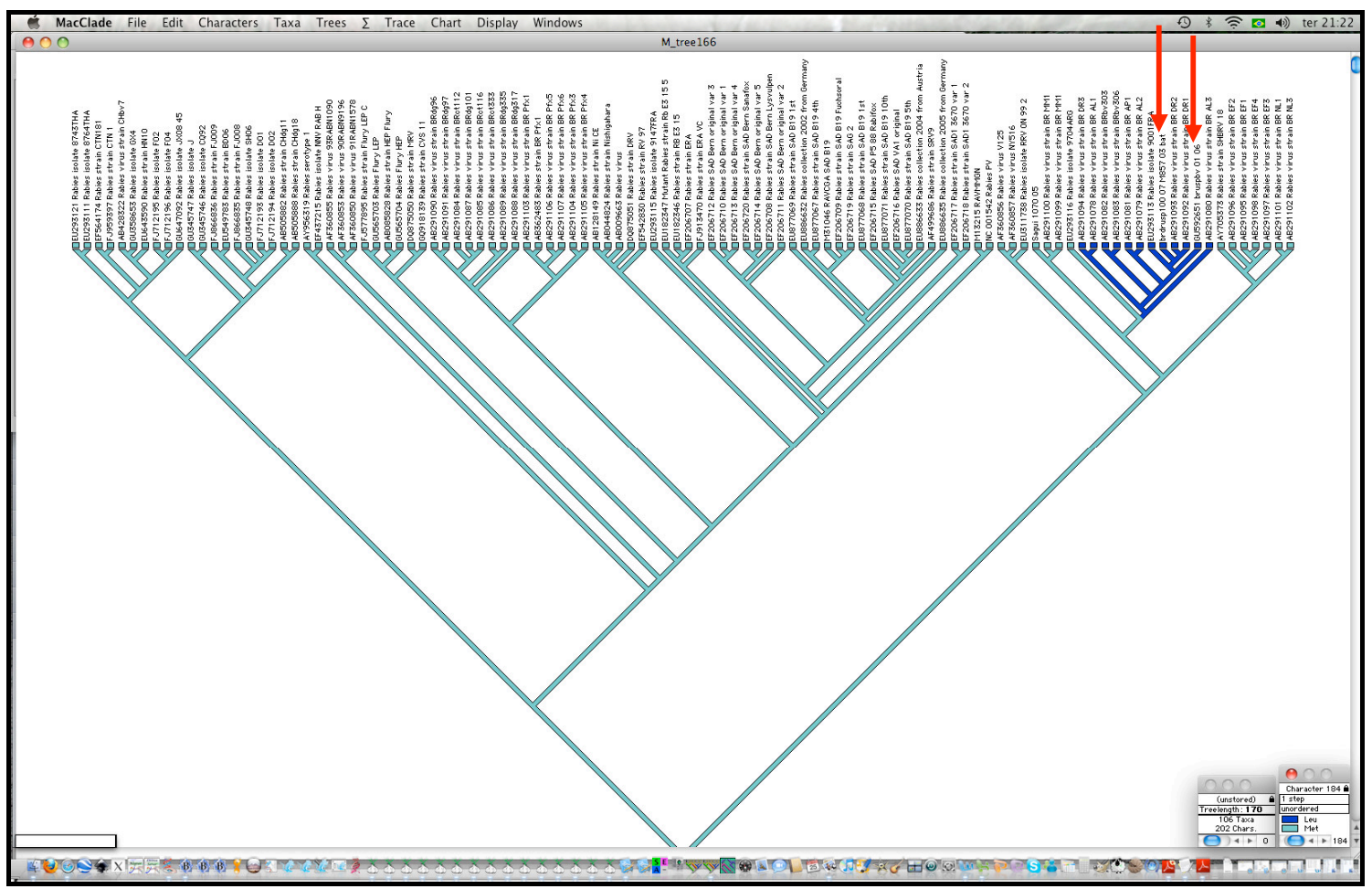

Figura 38c. Ilustração gerada pelo programa MacClade para o resíduo 184 da proteína de matriz.

Em azul escuro pode ser vista a Leucina para as amostras com variante genética mantida por morcegos hematófagos Desmodus rotundus entre elas as amostras brbvusp01/06 e brdrusp100/07, e a Isoleucina para as demais amostras analisadas.

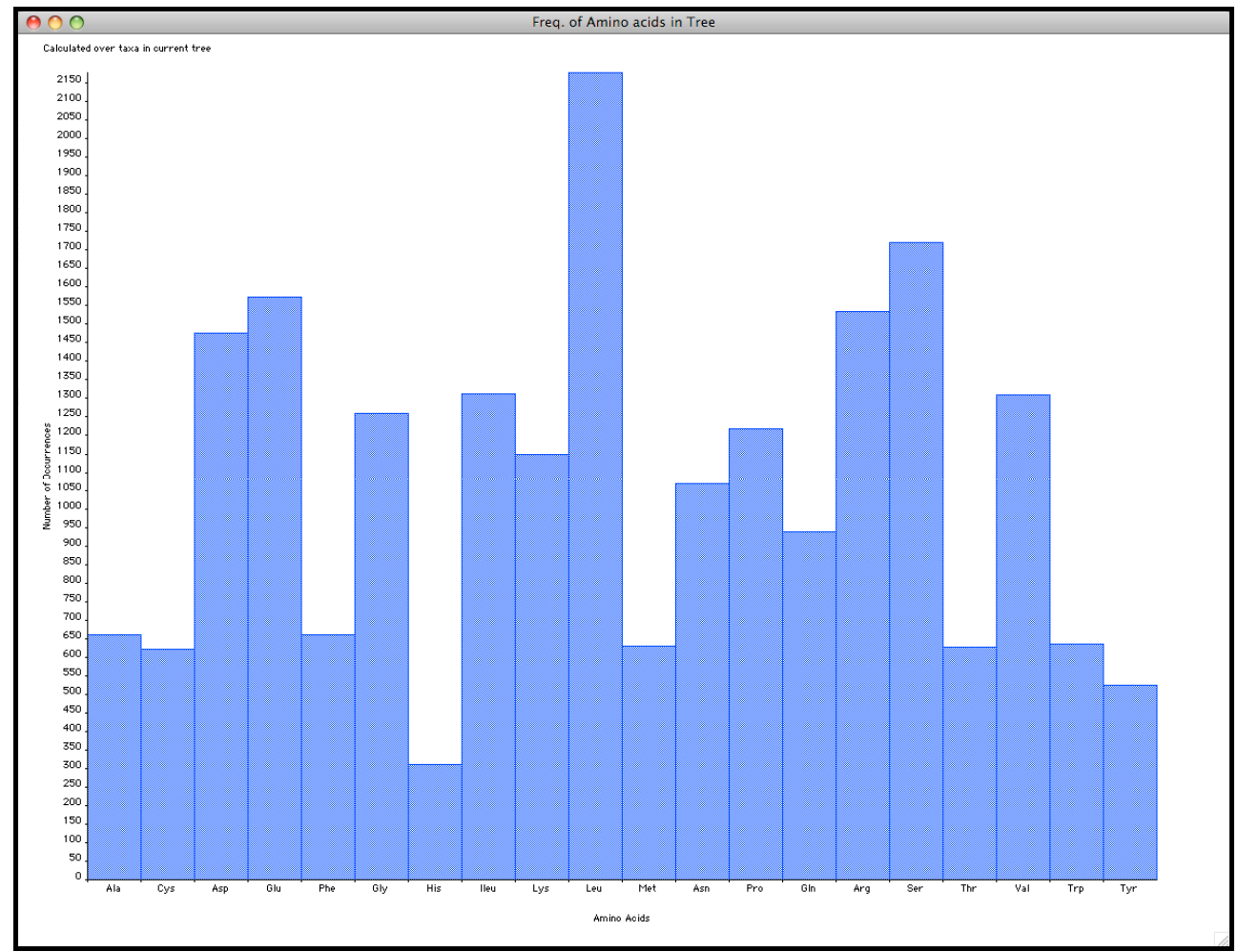

Figura 39. Gráfico com frequência de aminoácidos na proteína de matriz.

Análise para todas as sequências utilizadas na reconstrução da árvore. 
A figura 39 mostra a frequência geral de aminoácidos para a proteína de matriz sendo o mais frequente a Leucina e o menos frequente a Histidina. A figura 40 indica as taxas de mudanças de aminoácidos na proteína de matriz, onde pode ser observado que as maiores taxas de mudanças aconteceram do aminoácido Valina (V) para Isoleucina (I) / Isoleucina (I) para Valina (V), Leucina (L) para Prolina (P) e de Alanina (A) para Valina (V).

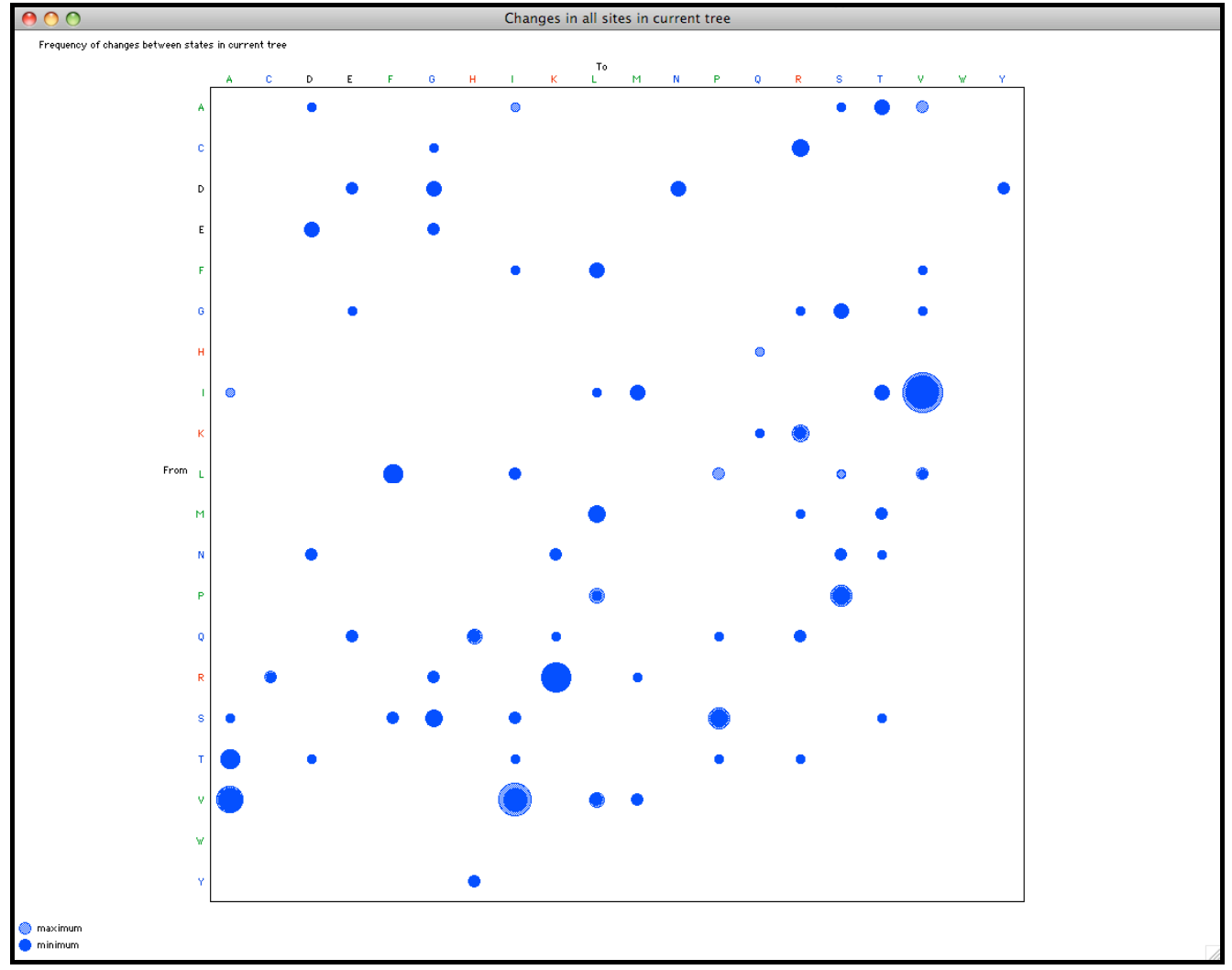

Figura 40. Gráfico de substituições de aminoácidos na proteína de matriz. Análise para todas as sequências utilizadas na reconstrução da árvore

A partir da análise de nucleotídeos obtida após o sequenciamento de todo o gene codificador para a glicoproteína da amostra controle brbvusp01/06 e a comparação filogenética com dados disponíveis no GenBank (ANEXO A) que descrevem genes também completos da glicoproteína pudemos observar na árvore filogenética (figuras 41 e 42) que a amostra brbvusp01/06 segregou juntamente com amostras pertencentes ao ciclo aéreo de transmissão. 


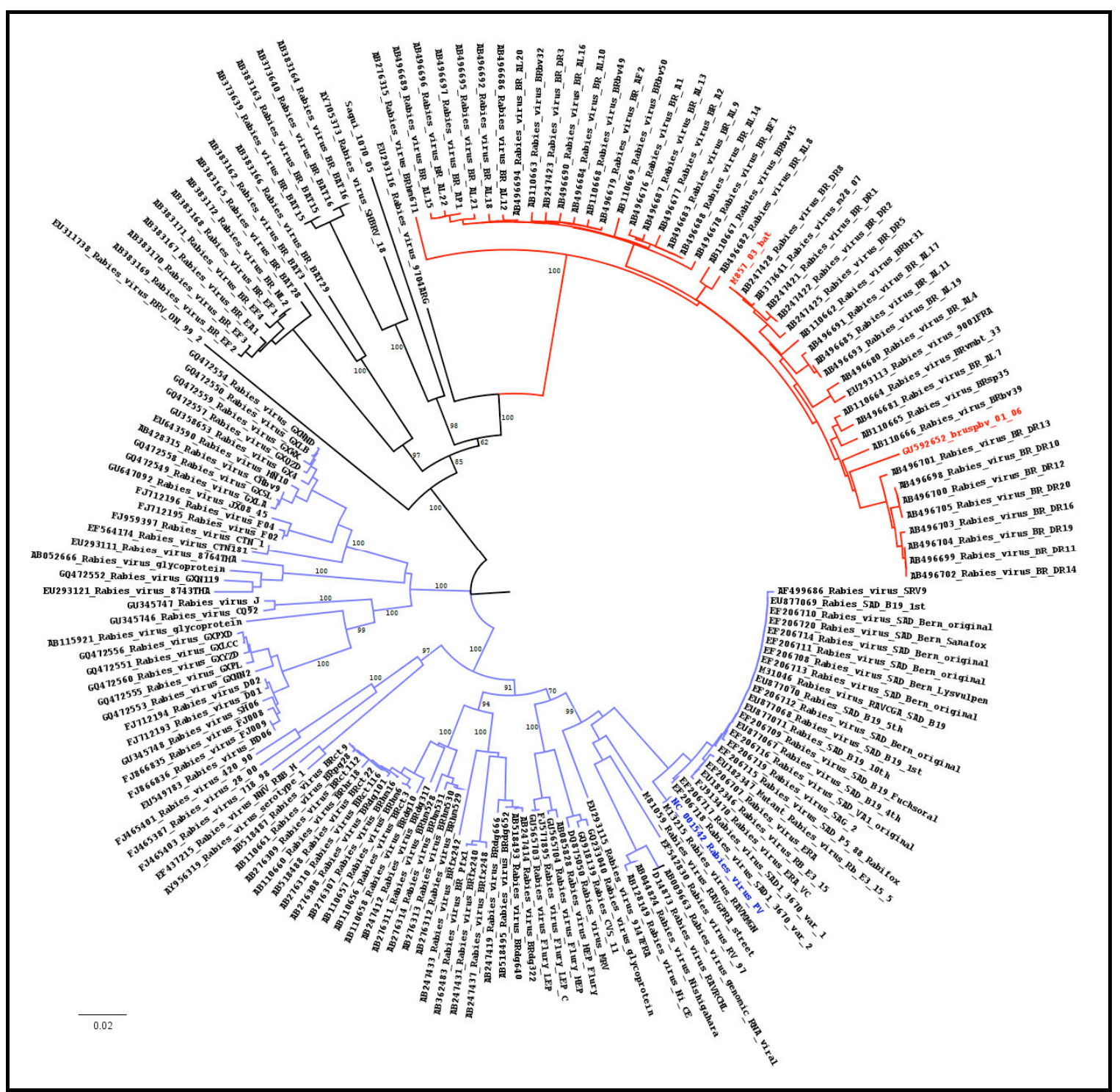

Figura 41. Árvore filogenética de máxima verossimilhança (ML) para glicoproteína.

Reconstruída pelo programa MEGA4 e realizada uma busca heurística (heuristic search) com o algorítmo "NJ". Os valores nos principais nós representam os valores de 10000 réplicas de bootstrap superiores a $50 \%$. 


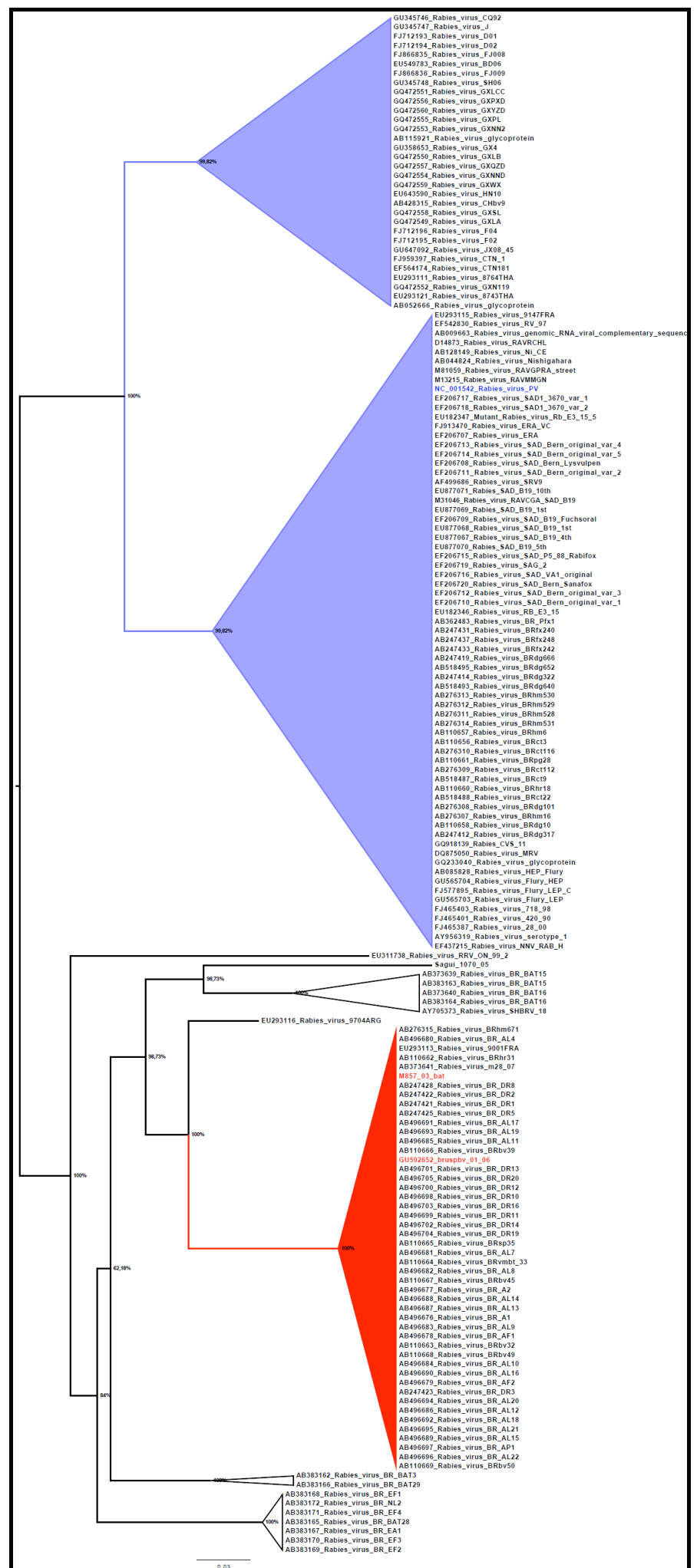

Figura 42. Árvore filogenética de máxima verossimilhança (ML) para glicoproteína.

Reconstruída pelo programa GARLi e realizada uma busca heurística (heuristic search) com o algorítmo "GRT+gama+I". Os valores nos principais nós representam os valores de 1000 réplicas de bootstrap superiores a $50 \%$. 
Tabela 6 - Substituições de aminoácidos encontradas para a proteína G

(Continua)

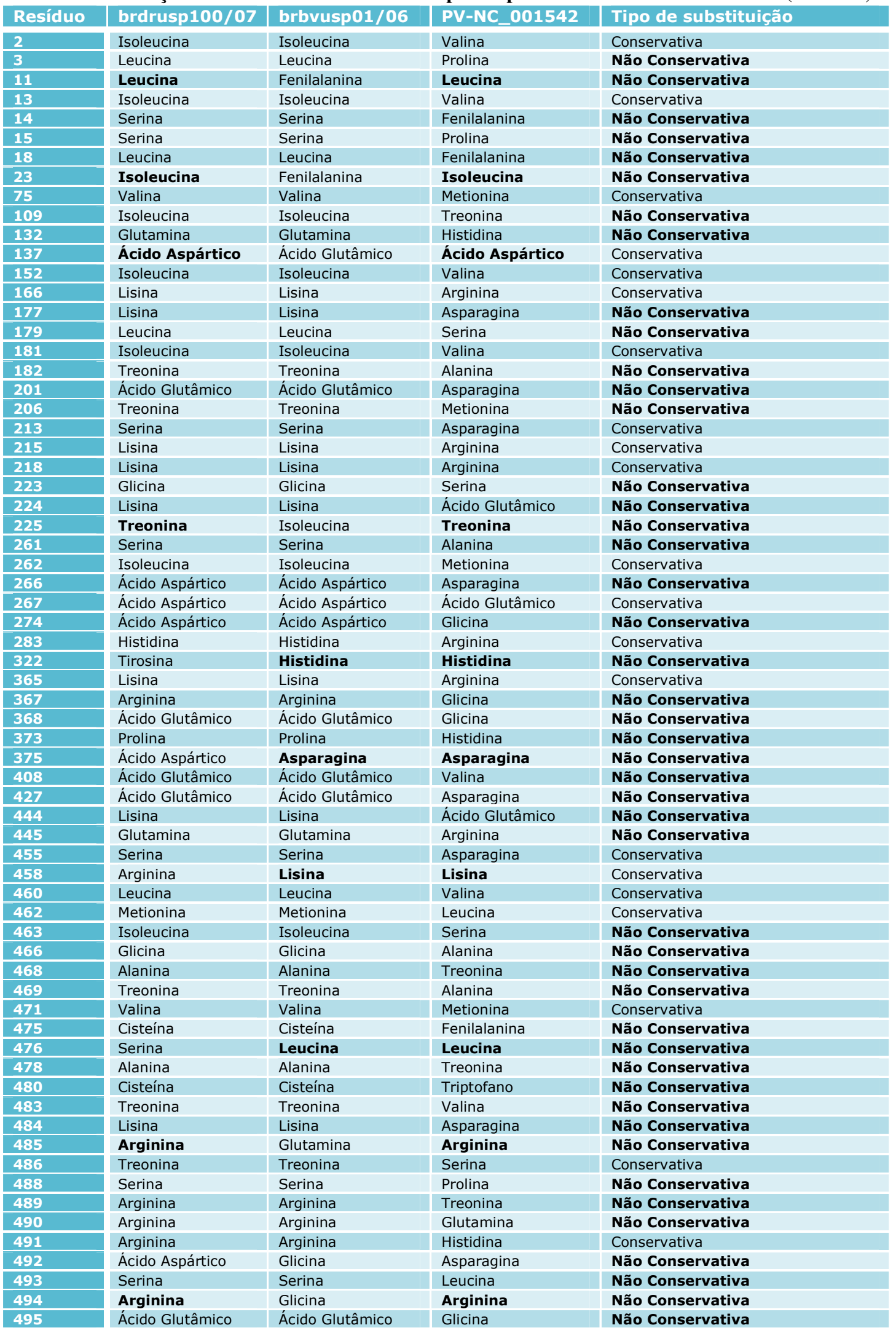


Tabela 6 - Substituições de aminoácidos encontradas para a proteína G

\begin{tabular}{|c|c|c|c|c|}
\hline Resíduo & brdrusp 100/07 & brbvusp01/06 & PV-NC_001542 & Tipo de substituição \\
\hline 496 & Serina & Leucina & Treonina & Conservativa/ Não Conservativa \\
\hline 497 & Ácido Glutâmico & Glicina & Glicina & Não Conservativa \\
\hline 498 & Lisina & Lisina & Arginina & Conservativa \\
\hline 499 & Lisina & Lisina & Ácido Glutâmico & Não Conservativa \\
\hline 501 & Treonina & Treonina & Serina & Conservativa \\
\hline 502 & Valina & Alanina & Valina & Conservativa \\
\hline 506 & Treonina & Treonina & Serina & Conservativa \\
\hline 507 & Arginina & Arginina & Glicina & Não Conservativa \\
\hline 509 & Valina & Valina & Isoleucina & Conservativa \\
\hline 510 & Valina & Valina & Isoleucina & Conservativa \\
\hline 515 & Leucina & Leucina & Serina & Não Conservativa \\
\hline 519 & Ácido Glutâmico & Ácido Glutâmico & Glicina & Não Conservativa \\
\hline 521 & Ácido Aspártico & Ácido Aspártico & Ácido Glutâmico & Conservativa \\
\hline 522 & Alanina & Alanina & Treonina & Não Conservativa \\
\hline 523 & Serina & Arginina & Glicina & Não Conservativa \\
\hline
\end{tabular}

A tabela 6 compreende as substituições de aminoácidos das amostras brbvusp01/06 (77 substituições) e brdrusp100/07 (75 substituições) em relação à amostra de referência PV. Em negrito na tabela aparecem 55 substituições não conservativas sendo 45 delas para as duas amostras, 4 apenas para o morcego hematófago e 6 apenas para a amostra isolada do bovino.

A glicoproteína apresentou cinco resíduos próprios da variante mantida por morcegos hematófagos, 213 com uma Serina (figura 43a), 367 com uma Arginina (figura 43b), 427 com um Ácido Glutâmico, 475 com uma Cisteína (figura 43c) e 521 com um Ácido Aspártico. Outros três sítios 478 com uma Alanina (figura 43d), 489 com uma Arginina e 493 com uma Serina foram comuns para as variantes relacionadas à D. rotundus e T. brasiliensis.

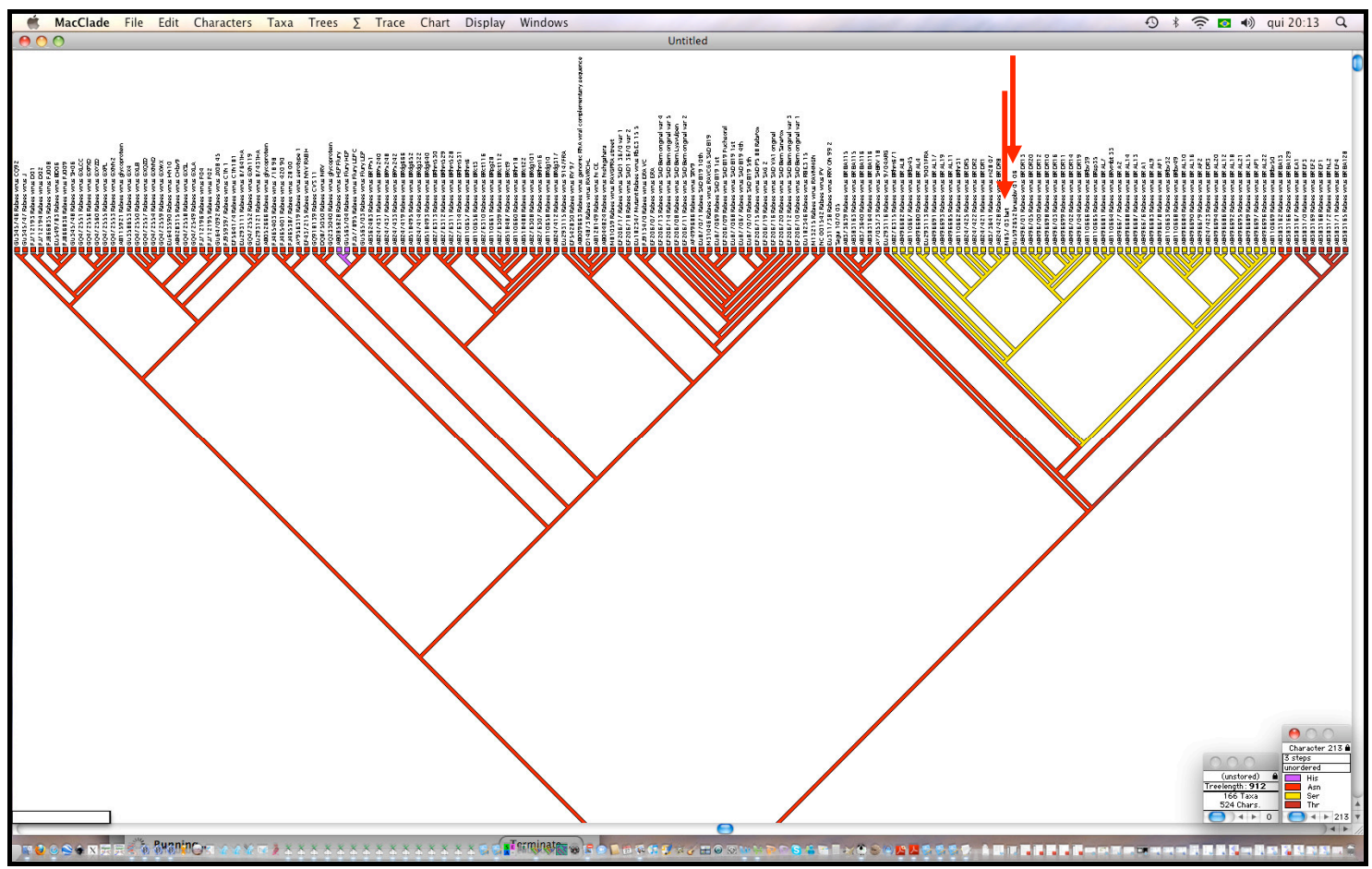

Figura 43a.Ilustração gerada pelo programa MacClade para o resíduo 213 da glicoproteína.

Em amarelo pode ser vista a Serina para as amostras com variante genética mantida por morcegos hematófagos Desmodus rotundus entre elas as amostras brbvusp01/06 e brdrusp100/07. 


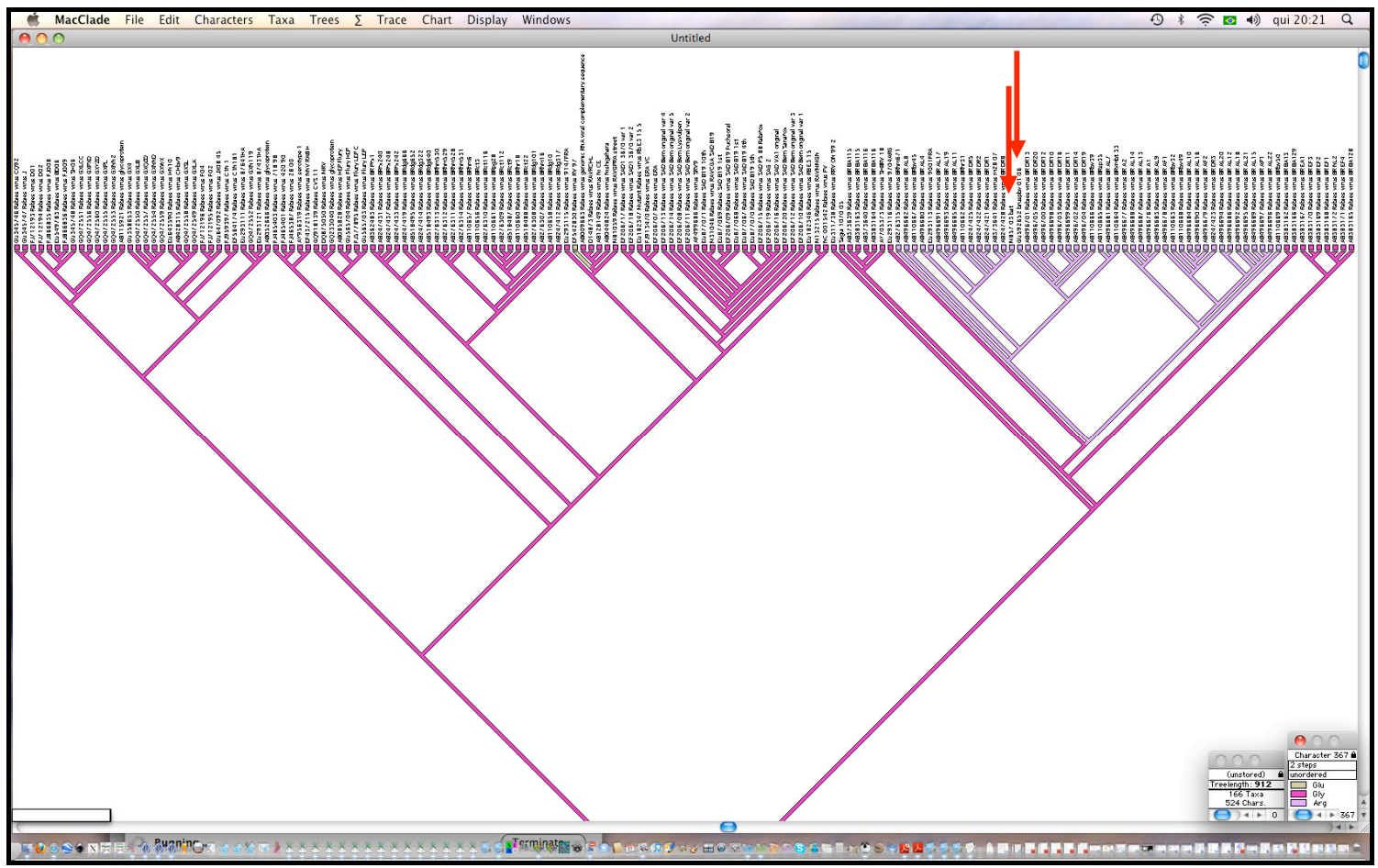

Figura 43b. Ilustração gerada pelo programa MacClade para o resíduo 367 da glicoproteína.

Em lilás pode ser vista a Arginina para as amostras com variante genética mantida por morcegos hematófagos Desmodus rotundus entre elas as amostras brbvusp01/06 e brdrusp100/07.

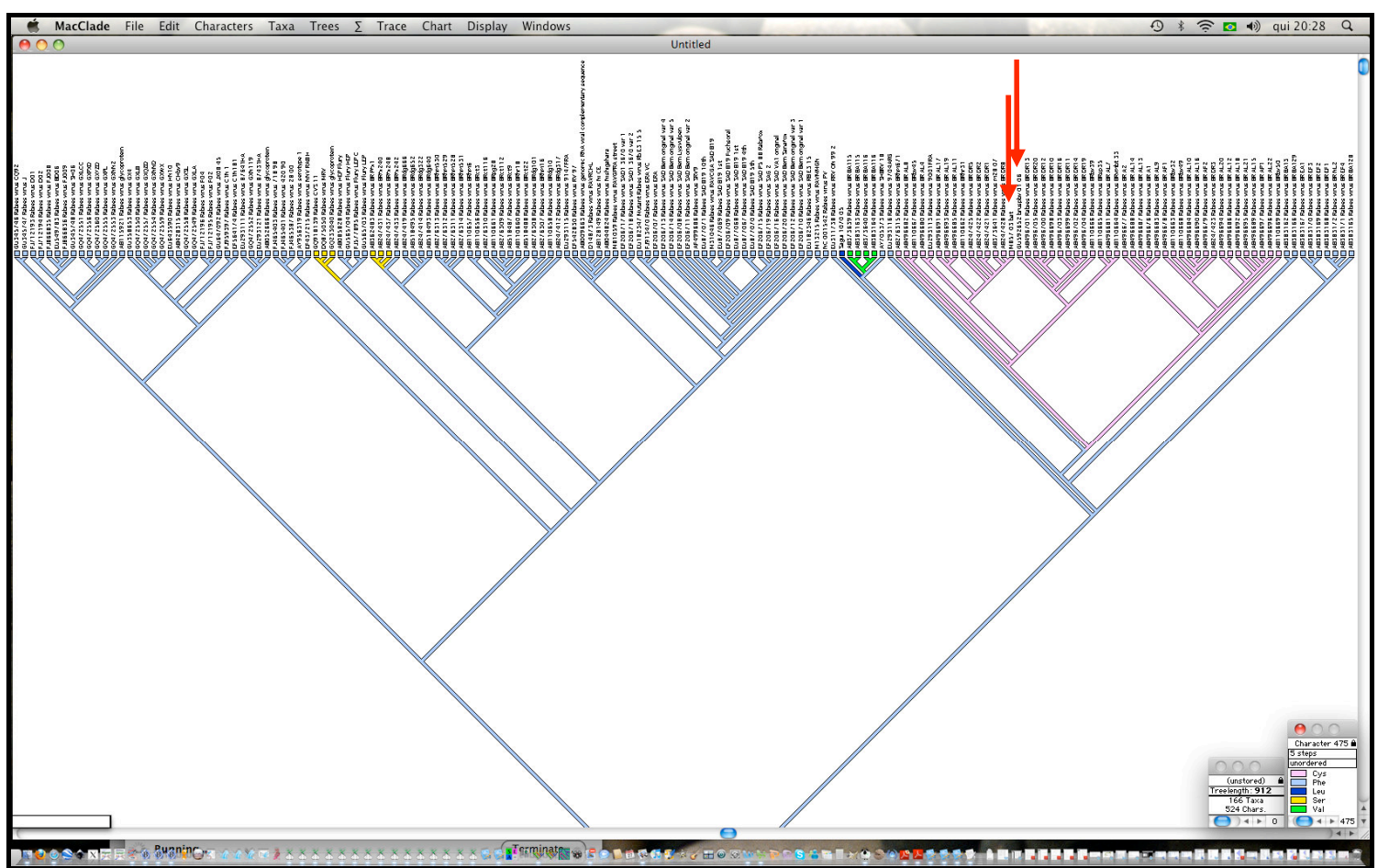

Figura 43c. Ilustração gerada pelo programa MacClade para o resíduo 475 da glicoproteína.

Em rosa pode ser vista a Cisteína para as amostras com variante genética mantida por morcegos hematófagos Desmodus rotundus entre elas as amostras brbvusp01/06 e brdrusp100/07. 


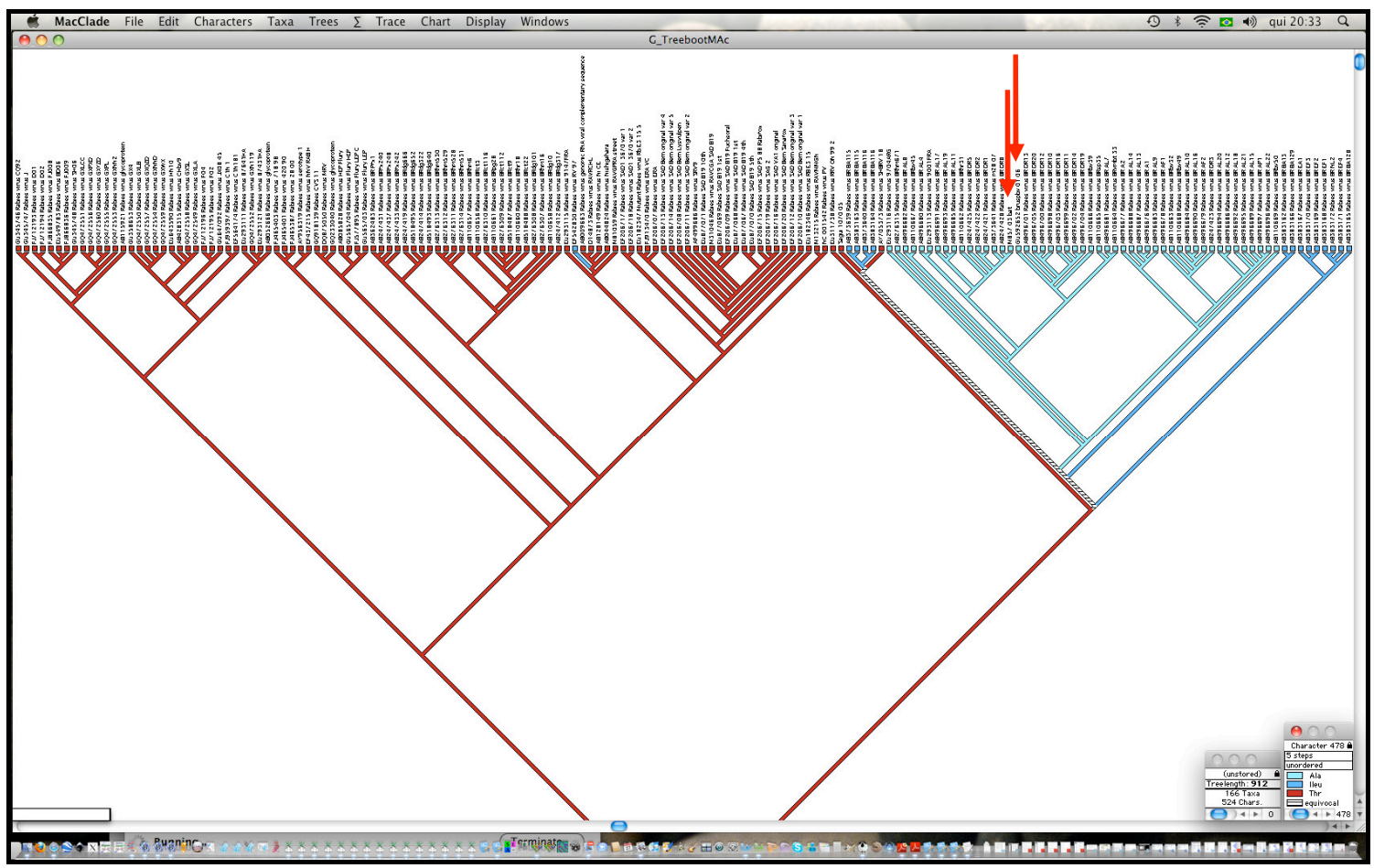

Figura 43d. Ilustração gerada pelo programa MacClade para o resíduo 478 da glicoproteína.

Em azul claro pode ser vista a Alanina para as variantes mantidas por morcegos hematófagos Desmodus rotundus e morcegos insetívoros Tadarida brasiliensis.

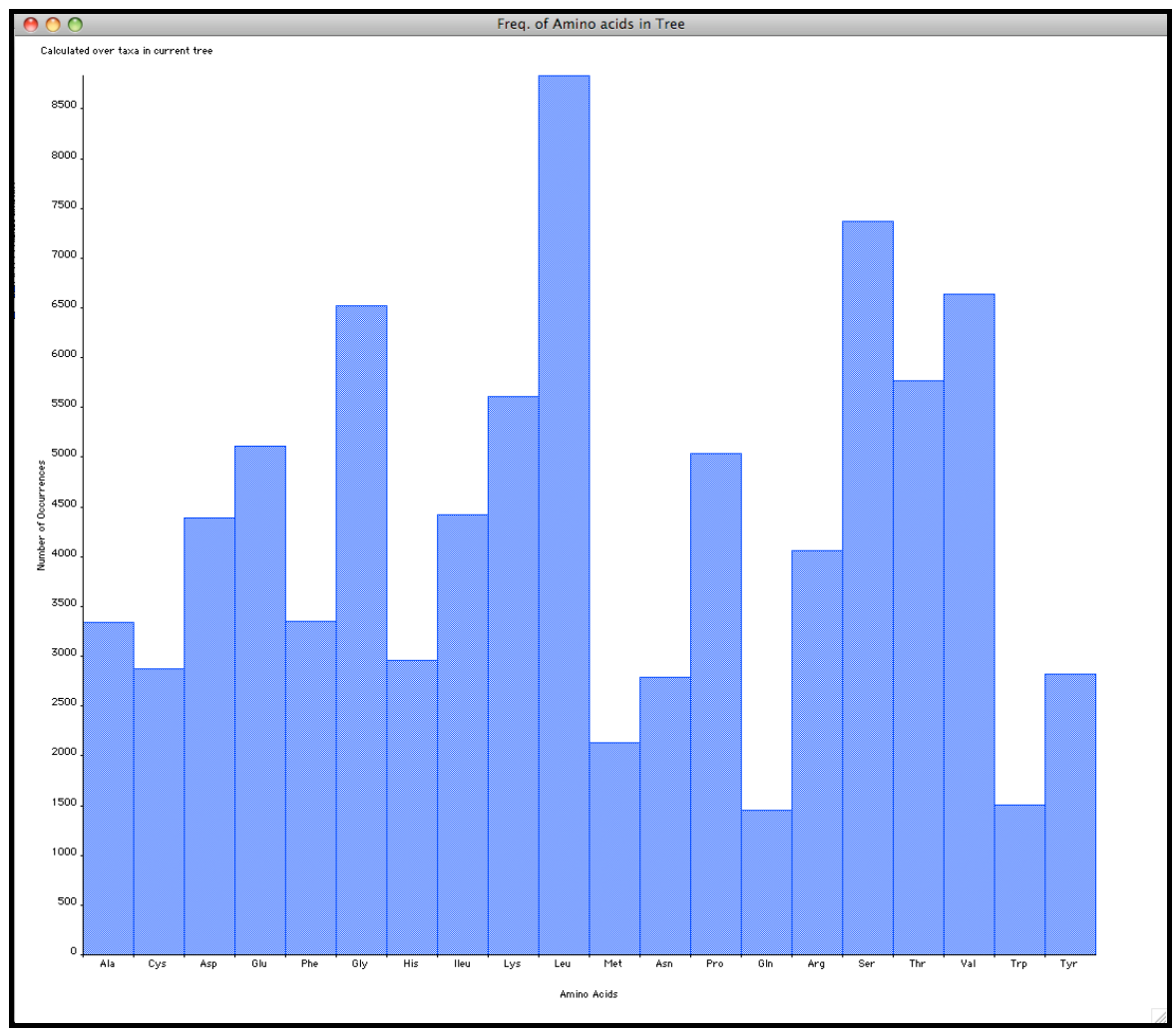

Figura 44. Gráfico com frequência de aminoácidos na glicoproteína.

Análise para todas as sequências utilizadas na reconstrução da árvore 
A figura 44 mostra a frequência geral de aminoácidos para a glicoproteína sendo o mais frequente a Leucina e o menos frequente a Glutamina. A figura 45 indica as taxas de mudanças de aminoácidos na proteína de matriz, onde pode ser observado que as maiores taxas de mudanças aconteceram do aminoácido Isoleucina (I) para Treonina (T) e de Serina (S) para Treonina $(\mathrm{T})$.

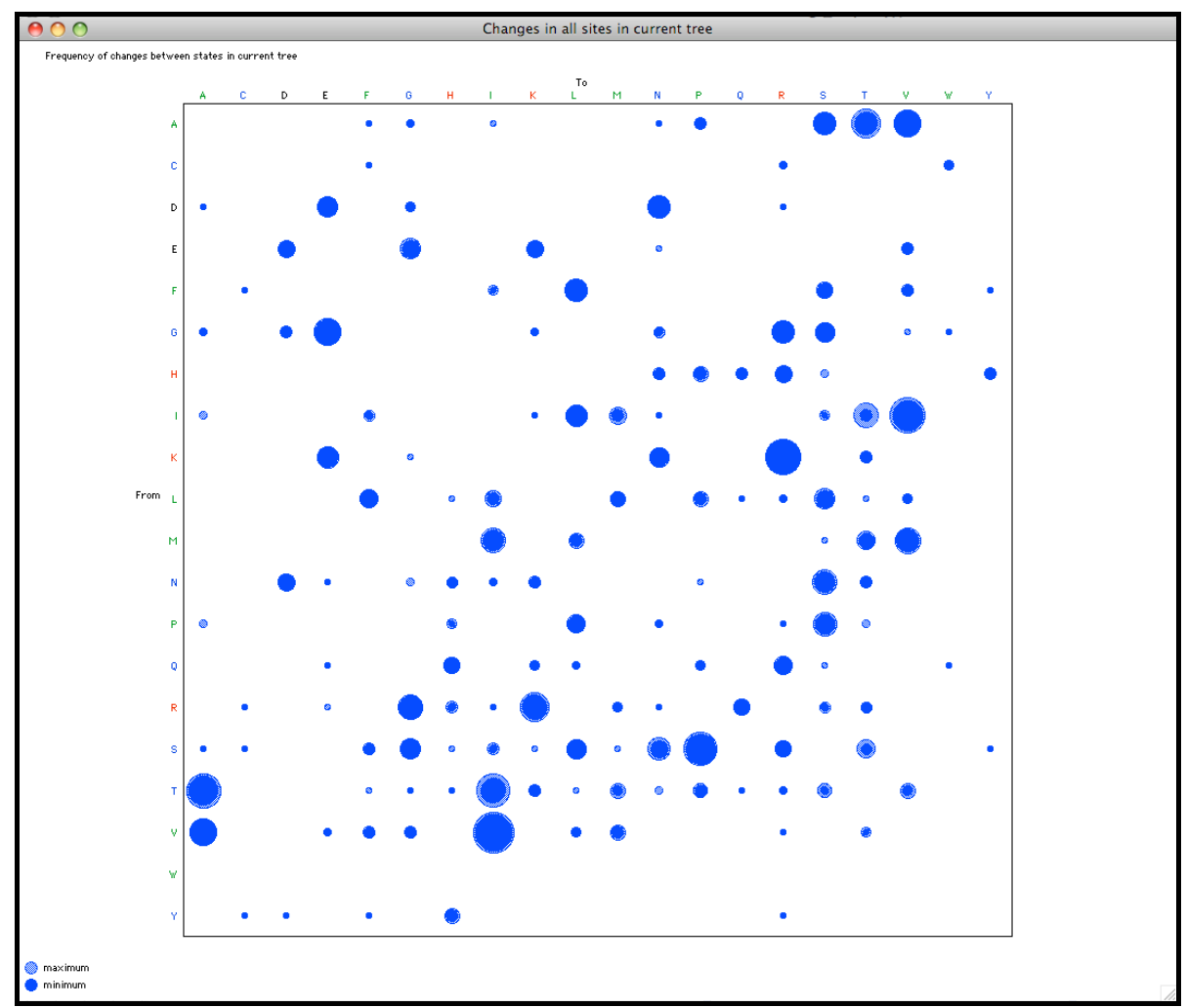

Figura 45. Gráfico de substituição de aminoácidos na glicoproteína. Análise para todas as sequências utilizadas na reconstrução da árvore.

A porção inicial da polimerase da amostra brbvusp01/06 foi sequenciada além de outros três fragmentos (fragmento 1 com 801 nucleotídeos, fragmento 2 com 786 nucletídeos, fragmento 3 com 864 nucleotídeos e fragmento 4 com 2519 nucleotídeos) totalizando 4967 $(76,2 \%)$ de 6515 nucleotídeos na amostra PV e na amostra brdrusp100/07 foram mapeados 2910 nucleotídeos em 5 fragmentos descontínuos (fragmento 2a com 708 nucleotídeos, fragmento 3a com 357 nucleotídeos, fragmento 4a com 801 nucleotídeos, fragmento 4b com 657 nucleotídeos e fragmento 4c com 387 nucleotídeos) totalizando 2910 (44,6\%) de 6515 nucleotídeos na amostra PV.

A figura 46 é um esquema com todos os fragmentos obtidos para a polimerase. Em cada um dos fragmentos foram realizadas as análises de verossimilhança com o MEGA4 e 
GARLi gerando 8 árvores para a amostra brbvusp01/06 (figuras 47 a 54) e 10 árvores para a amostra brdrusp100/07 (figuras 55 a 64) em todas elas o ciclo terrestre está identificado em azul e em a vermelho com a variante mantida por D. rotundus.

\begin{tabular}{|c|c|c|c|c|c|c|c|c|c|}
\hline & sazest & 9a595 & ass 5 B & aล978: & as1205 & sap1s17 & & \multicolumn{2}{|c|}{ s:2127[step] } \\
\hline \multicolumn{10}{|l|}{ PV } \\
\hline \multirow{3}{*}{$\begin{array}{l}\text { Bovino } \\
\text { Morcego }\end{array}$} & Fragrnento 1 & & Fragmento 2 & & entu 3 & & Framento 4 & & \\
\hline & & & Frasmento $2 \mathrm{a}$ & & Frag $3 a$ & Fragmento $4 a$ & Fragmento $4 \mathrm{~b}$ & & Frag 4c \\
\hline & & encas & $\operatorname{An} 344$ & & a.t 1234 & at1995 & $-1634=1852$ & Sta16 & at 2127 \\
\hline
\end{tabular}

Figura 46. Esquema das regiões sequenciadas para a polimerase viral. Amostras brbvusp01/06 e brdrusp100/07 comparadas à amostra padrão PV-NC_001542.

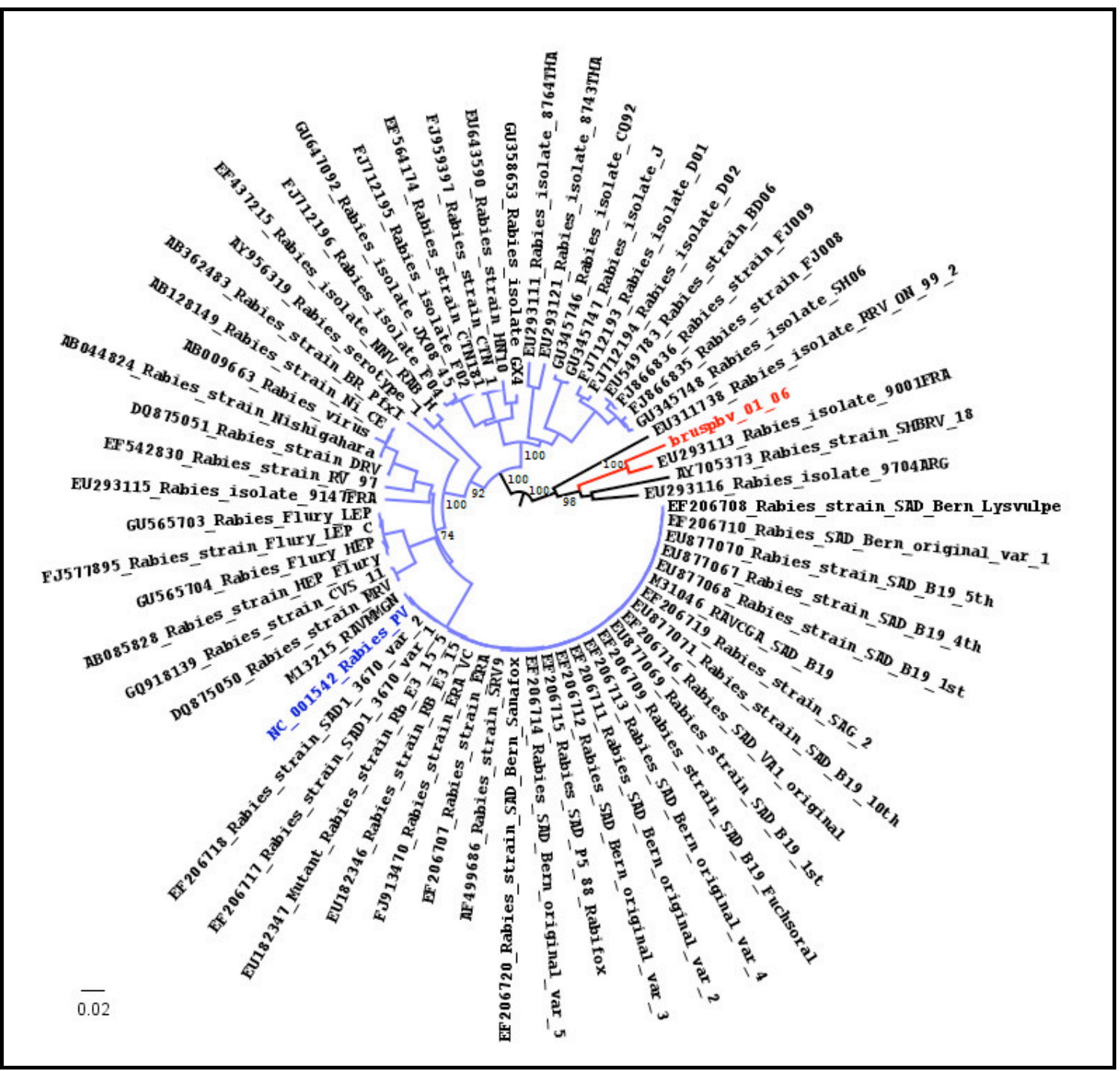

Figura 47. Árvore filogenética de máxima verossimilhança (ML) para a polimerase.

Análise da porção inicial da proteína L (fragmento 1), reconstruída pelo programa MEGA 4.0 e realizada uma busca heurística (heuristic search) com o algorítmo "NJ". Os valores nos principais nós representam os valores de 10000 réplicas de bootstrap superiores a 50\%. 


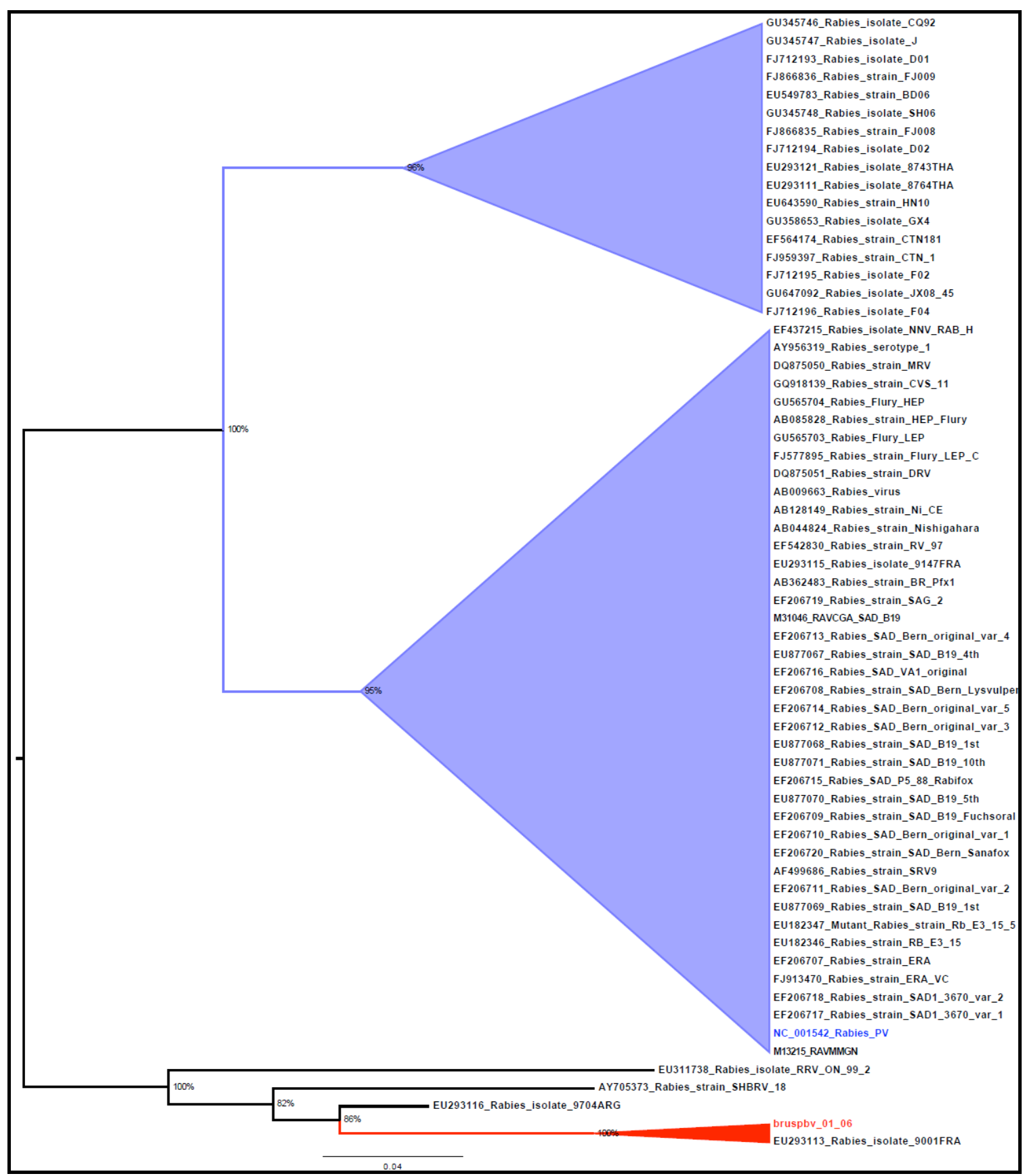

Figura 48. Árvore filogenética de máxima verossimilhança (ML) para a polimerase.

Análise da polimerase (parcial) da amostra brbvusp01/06 (fragmento 1), reconstruída pelo programa GARLi e realizada uma busca heurística (heuristic search) com o algorítmo "GTR+gama+I". Os valores nos principais nós representam os valores de 1000 réplicas de bootstrap superiores a $50 \%$. 


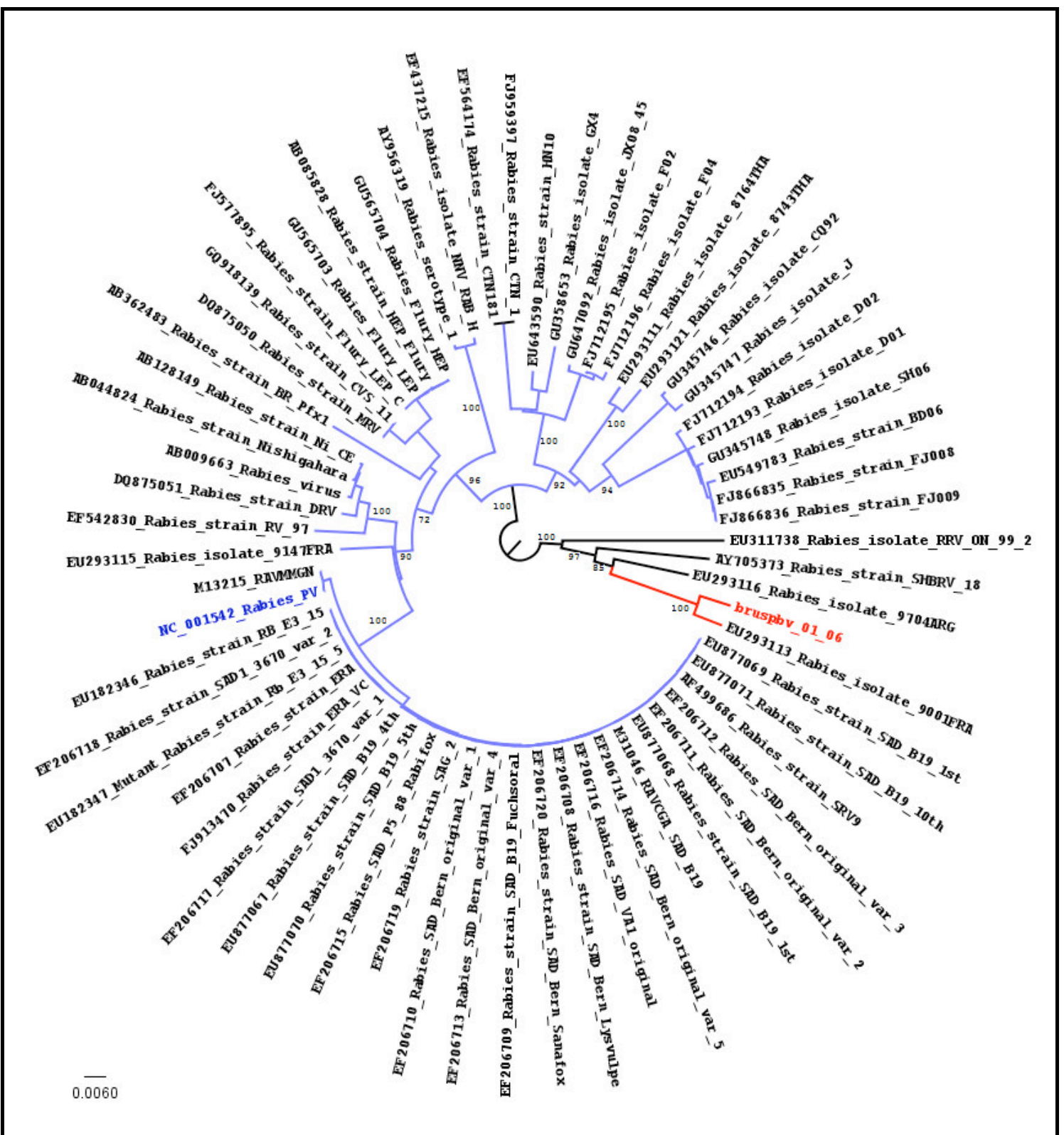

Figura 49. Árvore filogenética de máxima verossimilhança (ML) para a polimerase. Análise parcial da proteína L (fragmento 2), reconstruída pelo programa MEGA 4.0 e realizada uma busca heurística (heuristic search) com o algorítmo "NJ". Os valores nos principais nós representam os valores de 10000 réplicas de bootstrap superiores a 50\%. 


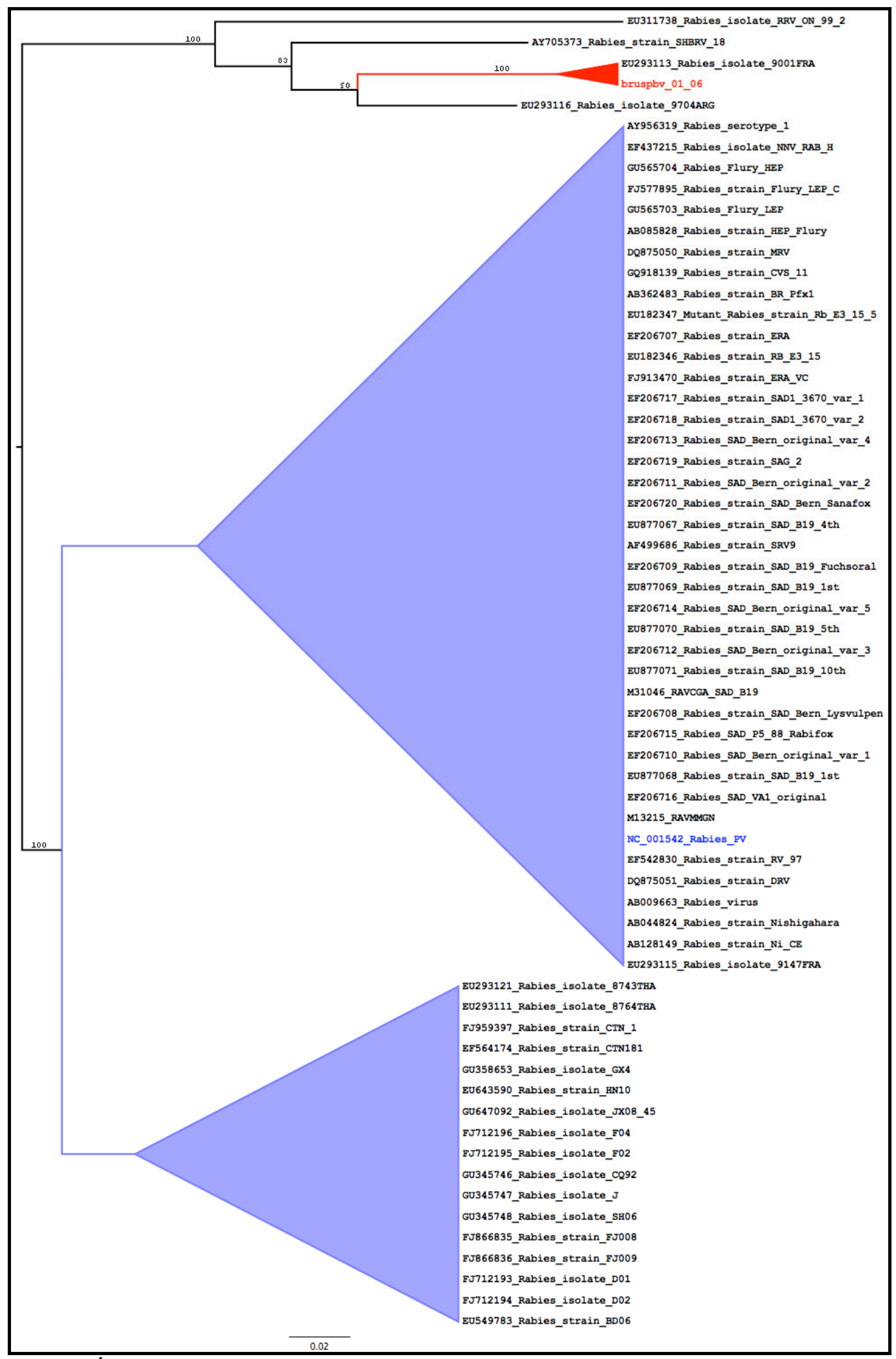

Figura 50. Árvore filogenética de máxima verossimilhança (ML) para a polimerase.

Análise parcial da amostra brbvusp01/06 (fragmento 2), reconstruída pelo programa GARLi e realizada uma busca heurística (heuristic search) com o algorítmo "GTR+gama+I". Os valores nos principais nós representam os valores de 1000 réplicas de bootstrap superiores a 50\%. 


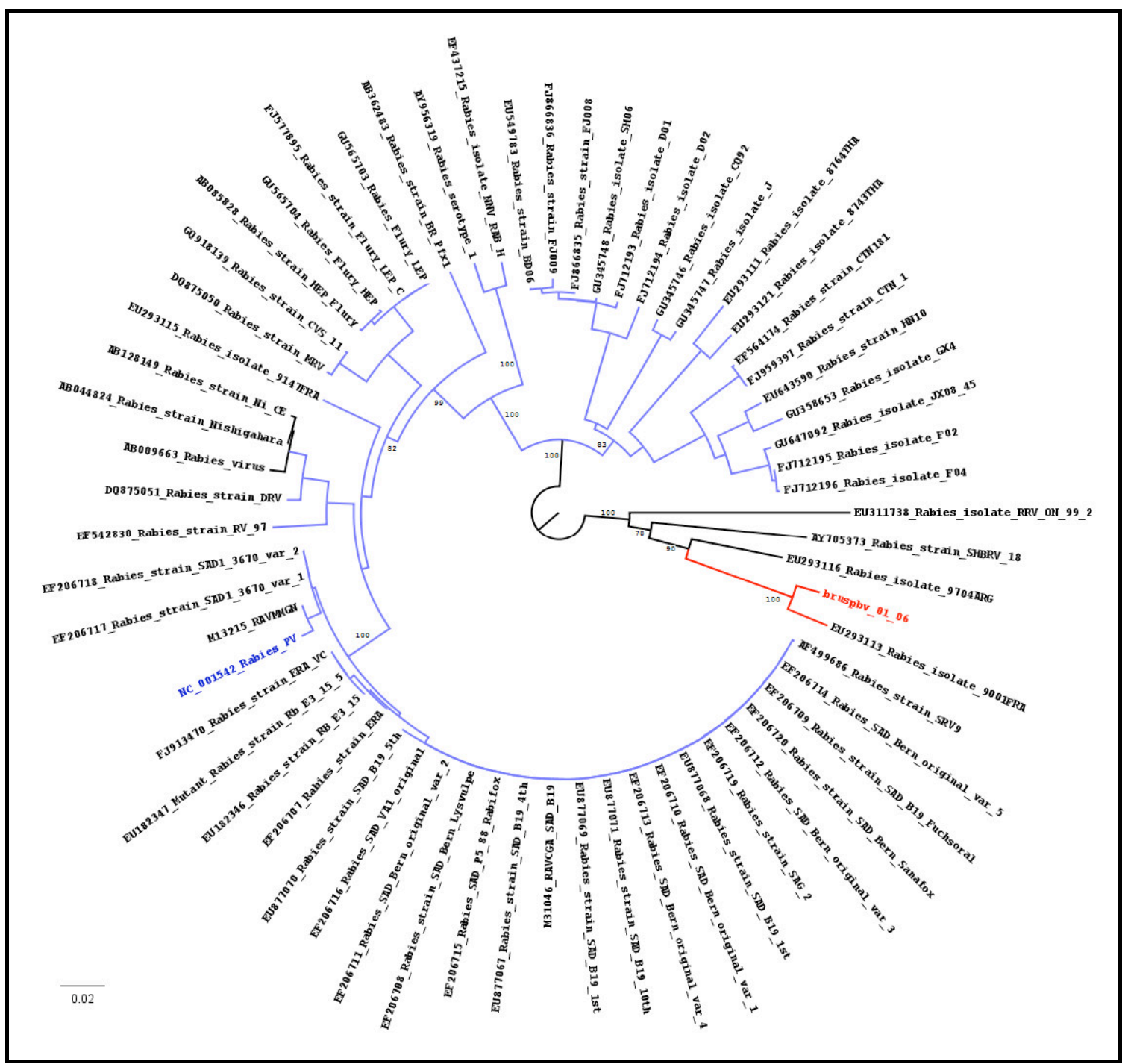

Figura 51. Árvore filogenética de máxima verossimilhança (ML) para a polimerase.

Análise parcial do fragmento 3, reconstruída pelo programa MEGA 4.0 e realizada uma busca heurística (heuristic search) com o algorítmo "NJ". Os valores nos principais nós representam os valores de 10000 réplicas de bootstrap superiores a $50 \%$. 


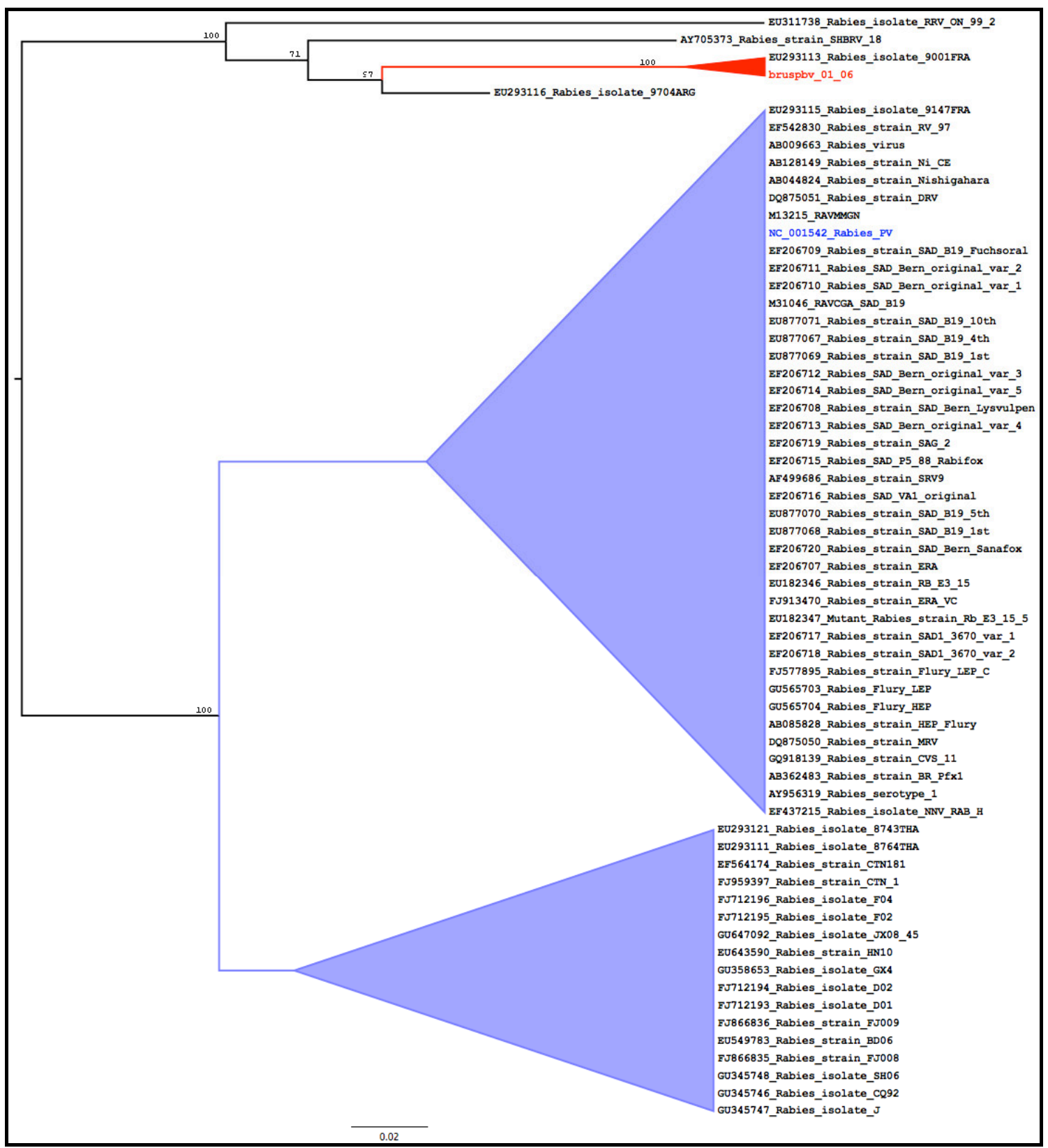

Figura 52. Árvore filogenética de máxima verossimilhança (ML) para a polimerase.

Análise parcial da amostra brbvusp01/06 (fragmento 3), reconstruída pelo programa GARLi e realizada uma busca heurística (heuristic search) com o algorítmo "GTR+gama+I". Os valores nos principais nós representam os valores de 1000 réplicas de bootstrap superiores a $50 \%$. 


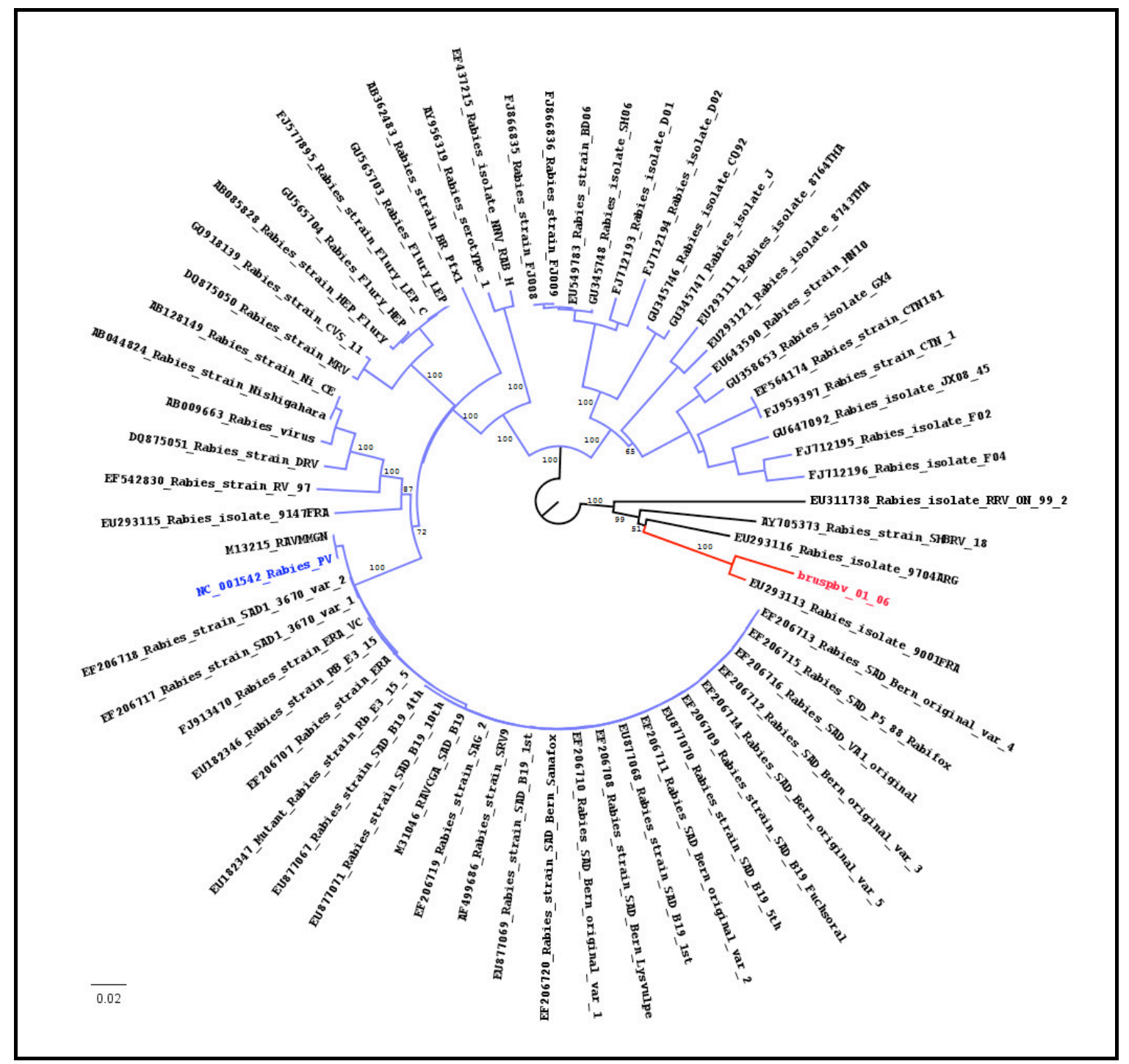

Figura 53. Árvore filogenética de máxima verossimilhança (ML) para a polimerase.

Análise parcial (fragmento 4), construída pelo programa MEGA 4.0 e realizada uma busca heurística (heuristic search) com o algorítmo "NJ". Os valores nos principais nós representam os valores de 10000 réplicas de bootstrap superiores a $50 \%$. 


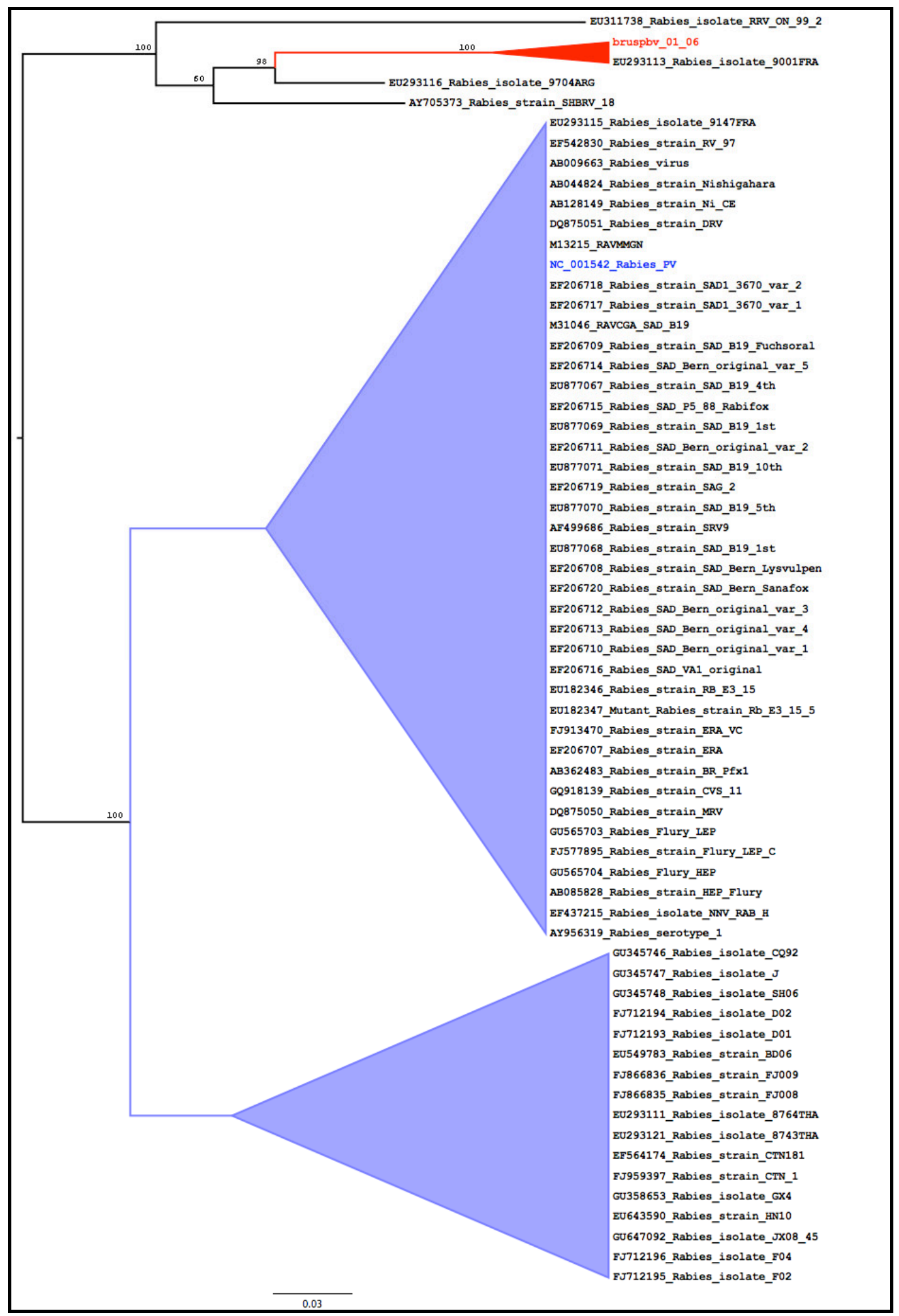

Figura 54. Árvore filogenética de máxima verossimilhança (ML) para a polimerase.

Análise parcial da amostra brbvusp01/06 (fragmento 4), construída pelo programa GARLi e realizada uma busca heurística (heuristic search) com o algorítmo "GTR+gama+I". Os valores nos principais nós representam os valores de 1000 réplicas de bootstrap superiores a 50\%. 


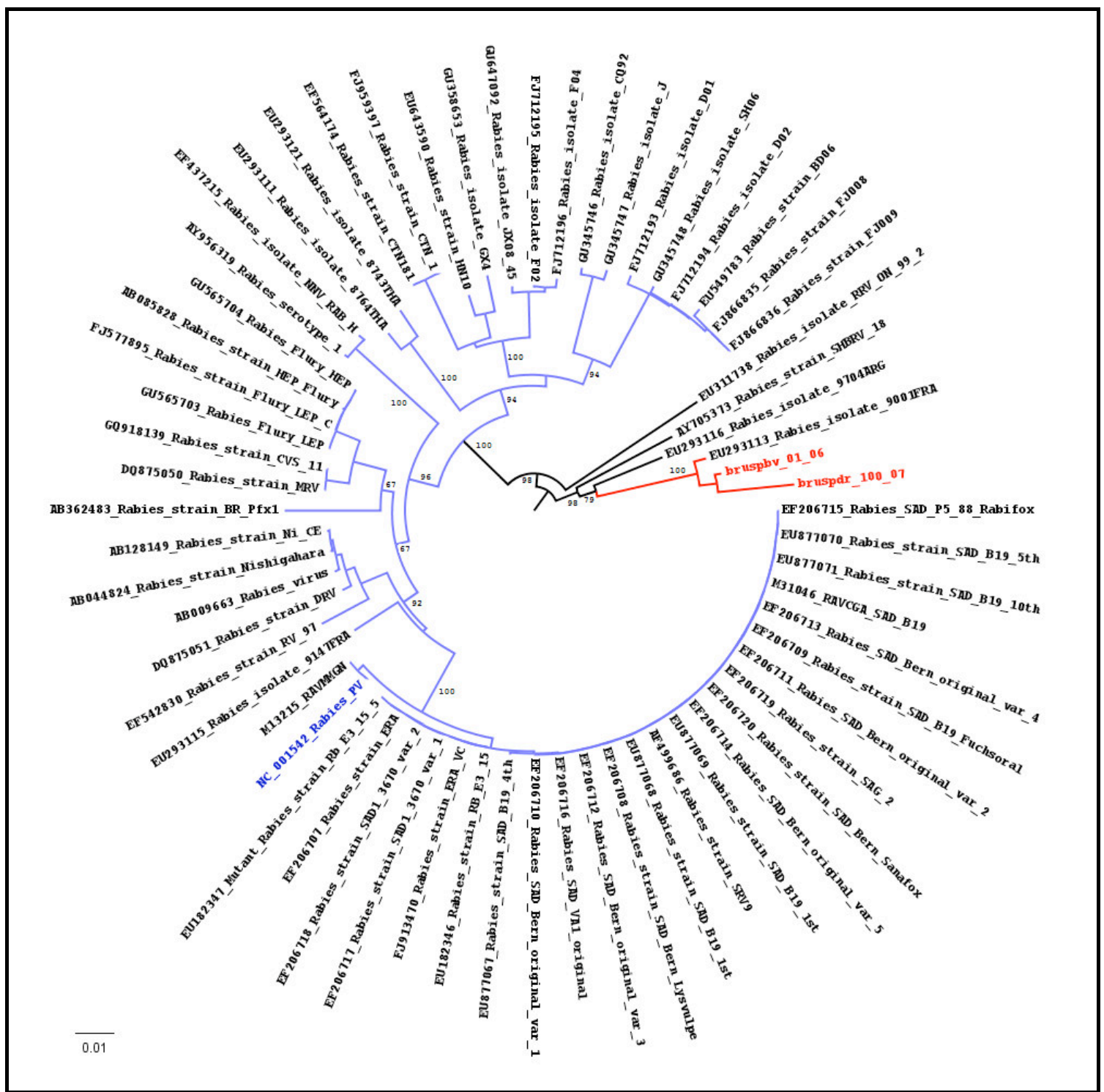

Figura 55. Árvore filogenética de máxima verossimilhança (ML) para a polimerase.

Análise parcial da amostra brdrusp100/07 (fragmento 2a), construída pelo programa MEGA 4.0 e realizada uma busca heurística (heuristic search) com o algorítmo "NJ". Os valores nos principais nós representam os valores de 10000 réplicas de bootstrap superiores a 50\%. 


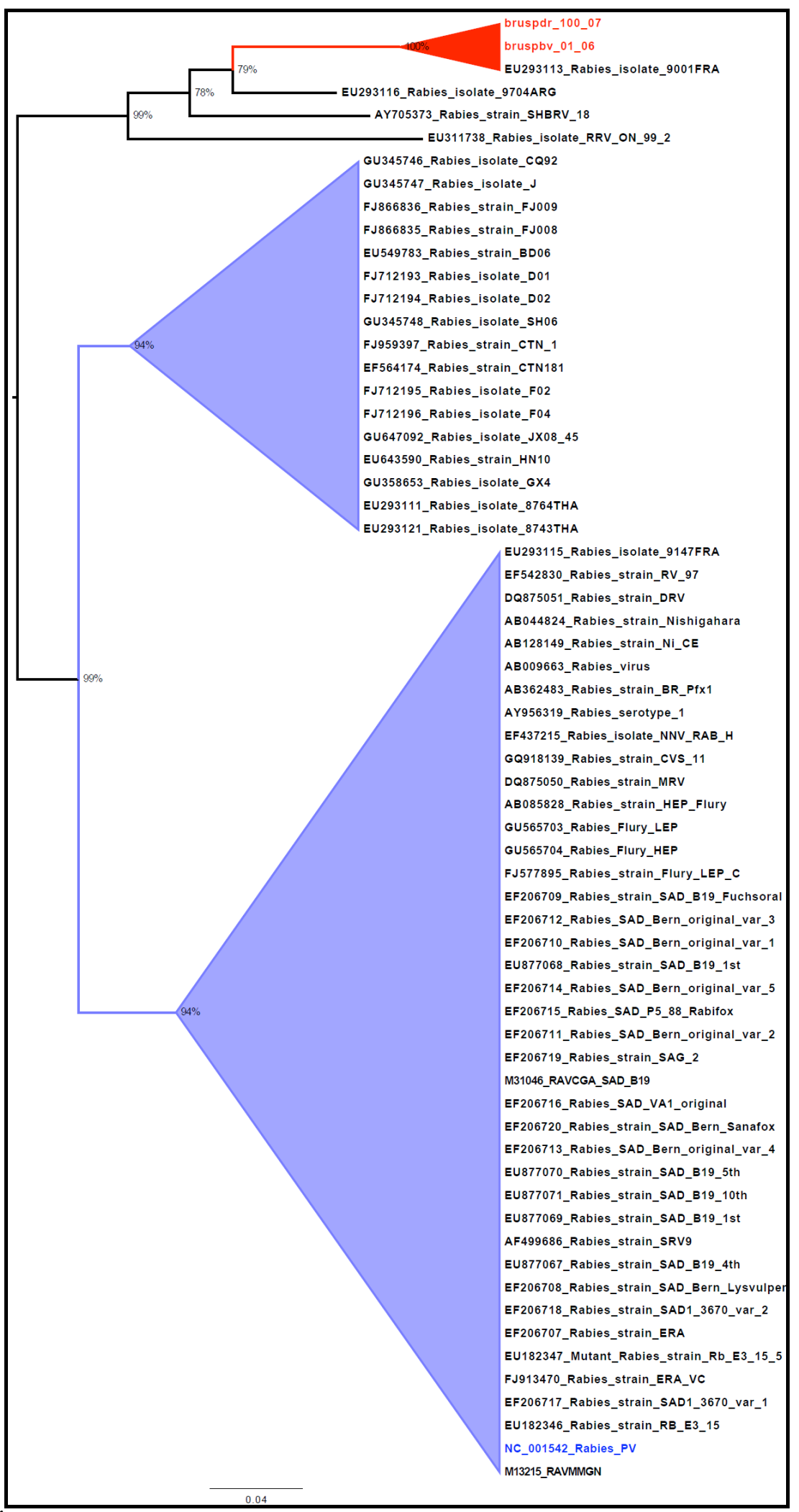

Figura 56. Árvore filogenética de máxima verossimilhança (ML) para a polimerase.

Análise parcial da amostra brdrusp100/07 (fragmento 2a), reconstruída pelo programa GARLi e realizada uma busca heurística (heuristic search) com o algorítmo "GTR+gama+I". Os valores nos principais nós representam os valores de 1000 réplicas de bootstrap superiores a $50 \%$. 


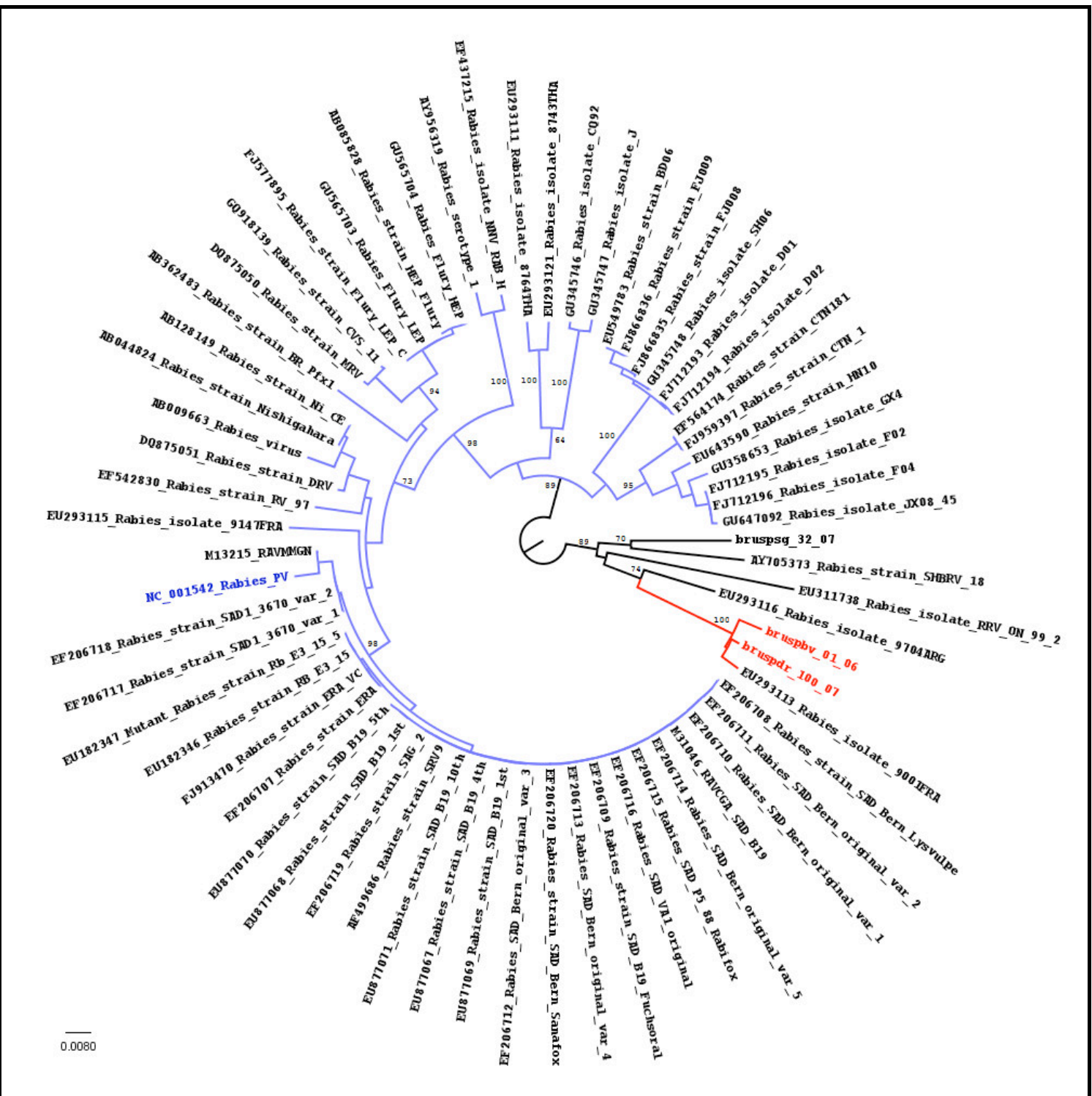

Figura 57. Árvore filogenética de máxima verossimilhança (ML) para a polimerase.

Análise parcial da amostra brdrusp100/07 (fragmento 3a), reconstruída pelo programa MEGA 4.0 e realizada uma busca heurística (heuristic search) com o algorítmo "NJ". Os valores nos principais nós representam os valores de 10000 réplicas de bootstrap superiores a $50 \%$. 


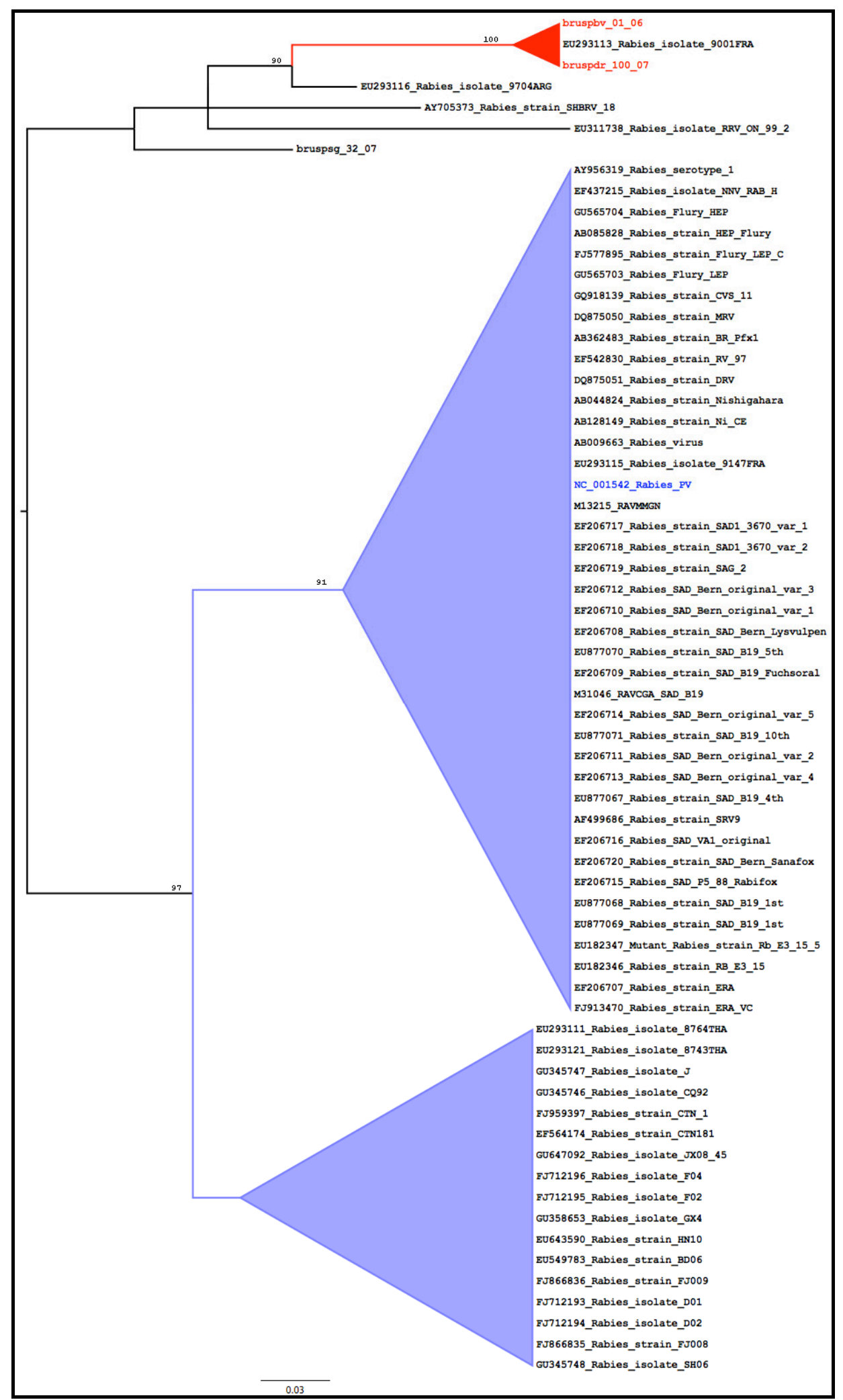

Figura 58. Árvore filogenética de máxima verossimilhança (ML) para a polimerase.

Análise parcial da amostra brdrusp100/07 (fragmento 3a), construída pelo programa GARLi e realizada uma busca heurística (heuristic search) com o algorítmo "GTR+gama+I". Os valores nos principais nós representam os valores de 1000 réplicas de bootstrap superiores a 50\%. 


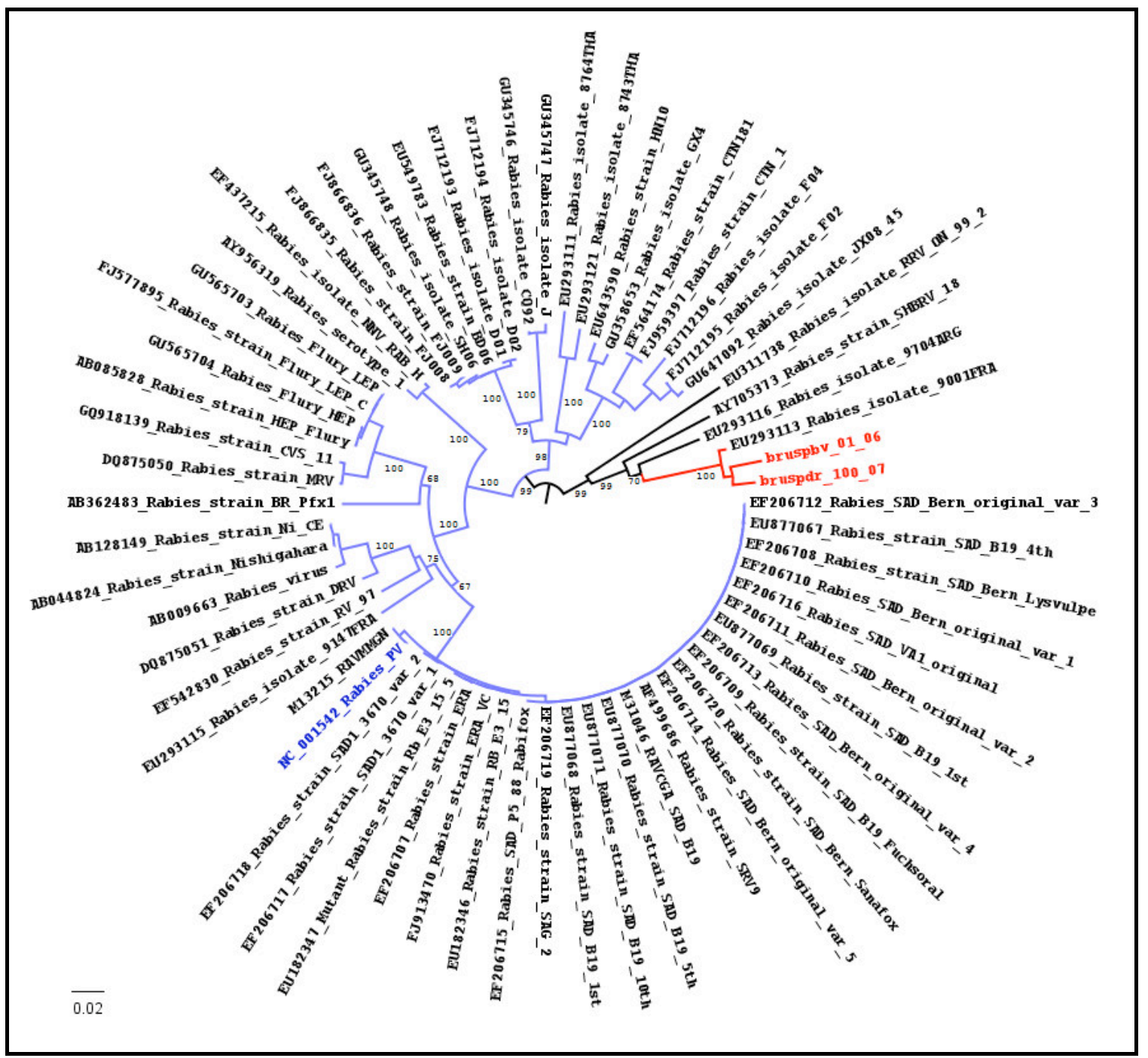

Figura 59. Árvore filogenética de máxima verossimilhança (ML) para a polimerase. Análise parcial da amostra brdrusp100/07 (fragmento 4a), construída pelo programa MEGA 4.0 e realizada uma busca heurística (heuristic search) com o algorítmo "NJ". Os valores nos principais nós representam os valores de 10000 réplicas de bootstrap superiores a 50\%. 


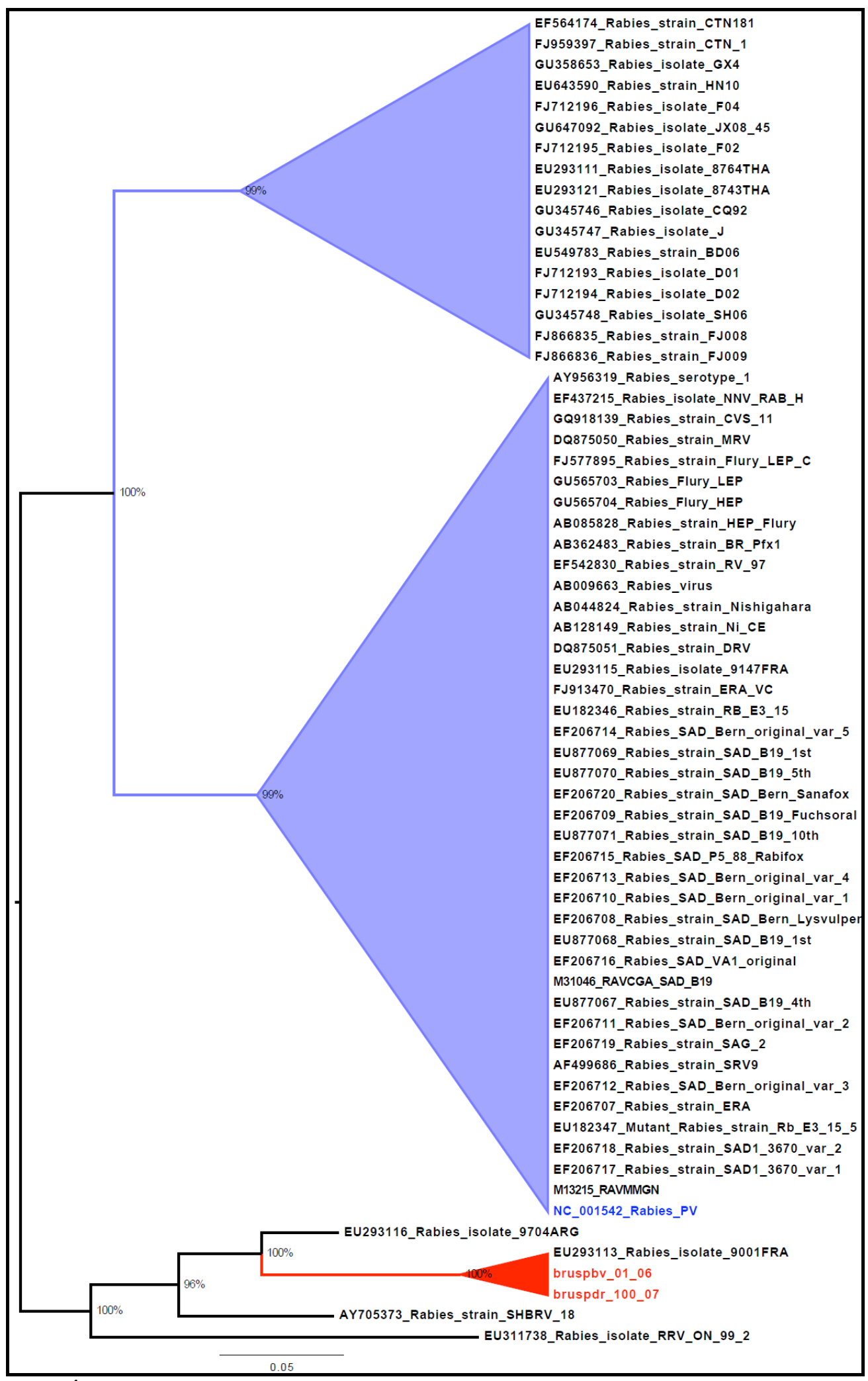

Figura 60. Árvore filogenética de máxima verossimilhança (ML) para a polimerase.

Análise parcial da amostra brdrusp100/07 (fragmento 4a), construída pelo programa GARLi e realizada uma busca heurística (heuristic search) com o algorítmo "GTR+gama+I". Os valores nos principais nós representam os valores de 1000 réplicas de bootstrap superiores a 50\%. 


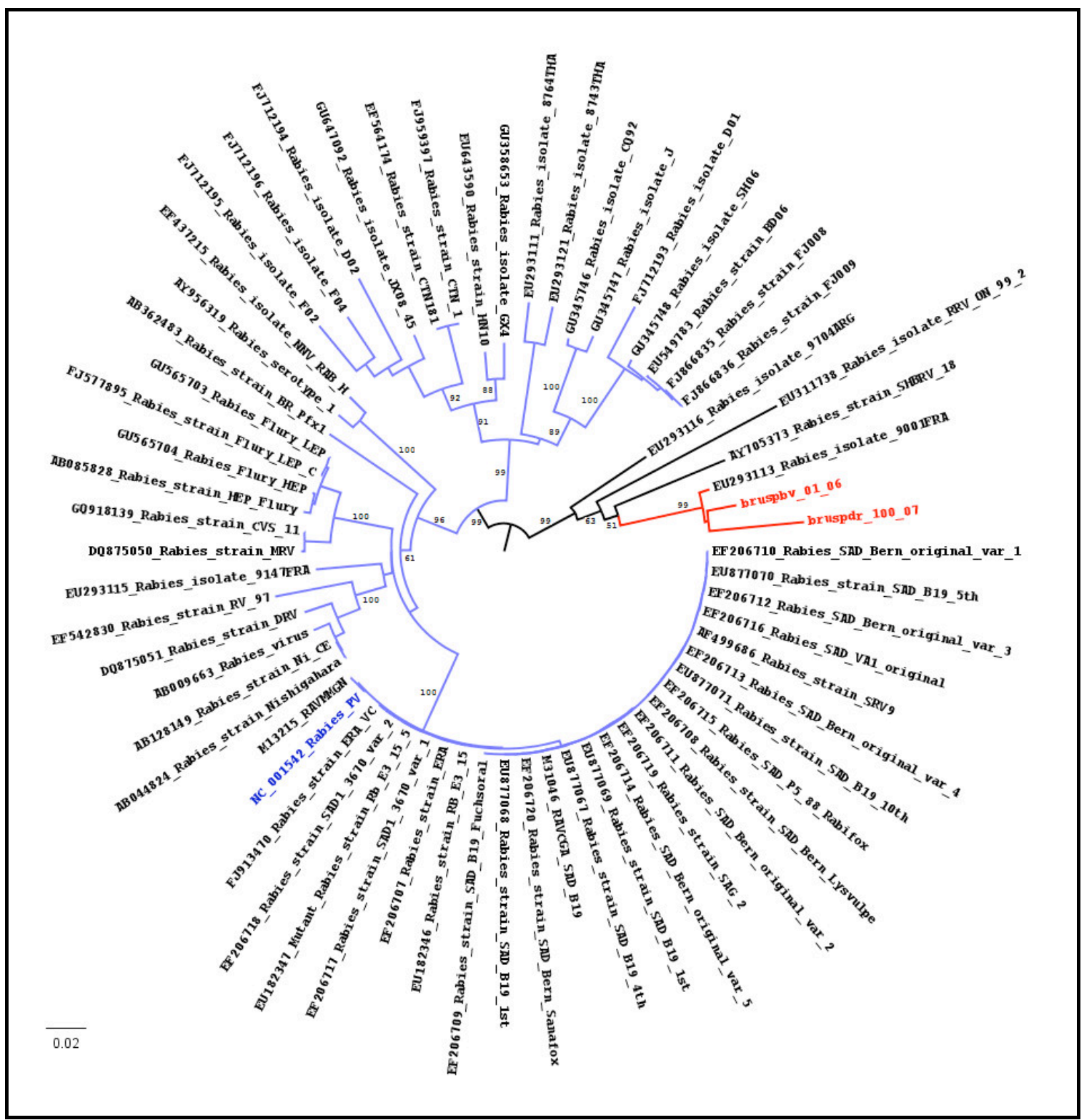

Figura 61. Árvore filogenética de máxima verossimilhança (ML) para a polimerase.

Análise parcial da amostra brdrusp100/07 (fragmento 4b), construída pelo programa MEGA 4.0 e realizada uma busca heurística (heuristic search) com o algorítmo "NJ". Os valores nos principais nós representam os valores de 10000 réplicas de bootstrap superiores a 50\%. 


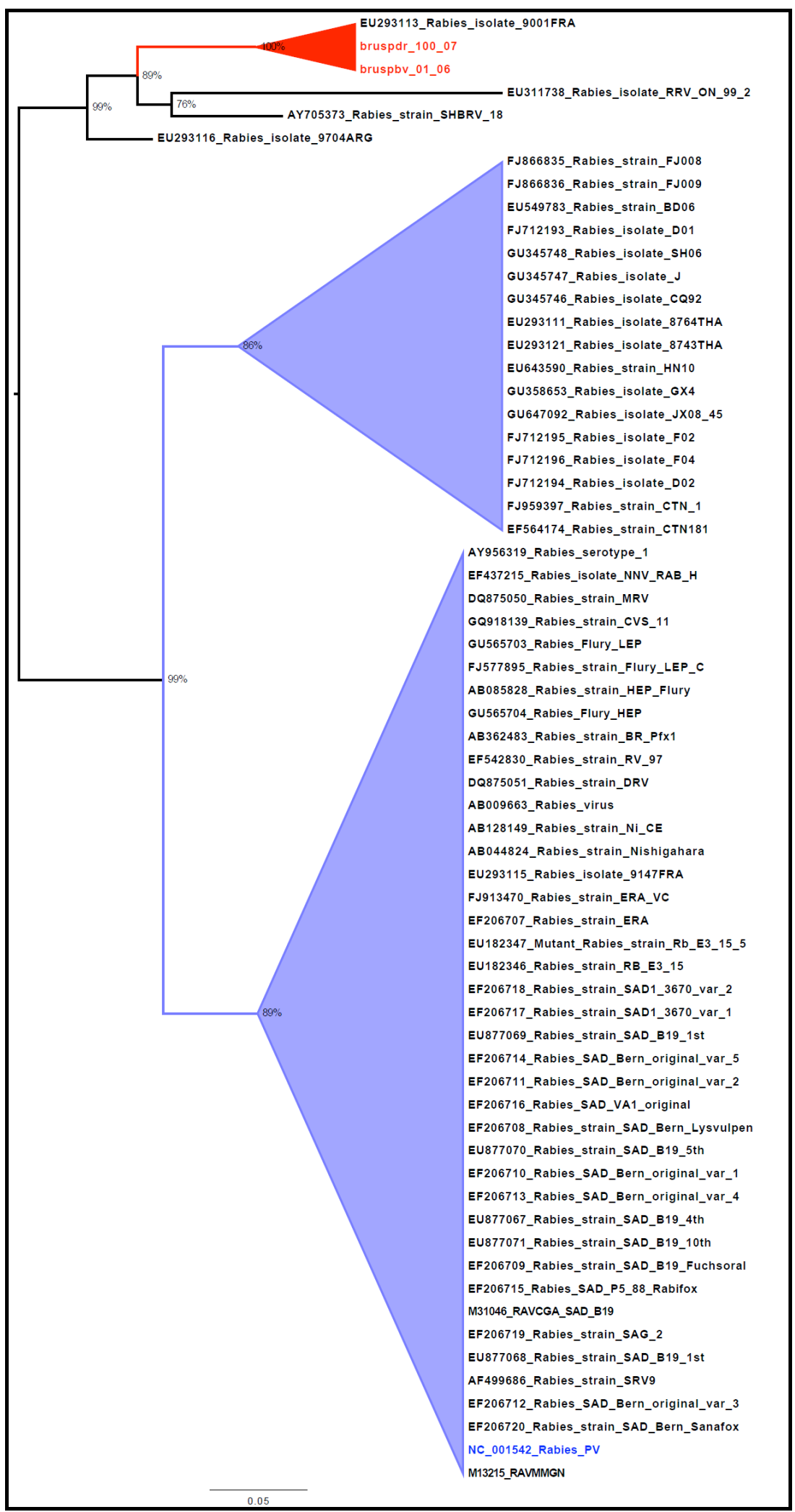

Figura 62. Árvore filogenética de máxima verossimilhança (ML) para a polimerase.

Análise parcial da amostra brdrusp100/07 (fragmento 4b), construída pelo programa GARLi e realizada uma busca heurística (heuristic search) com o algorítmo "GTR+gama+I". Os valores nos principais nós representam os valores de 1000 réplicas de bootstrap superiores a 50\%. 


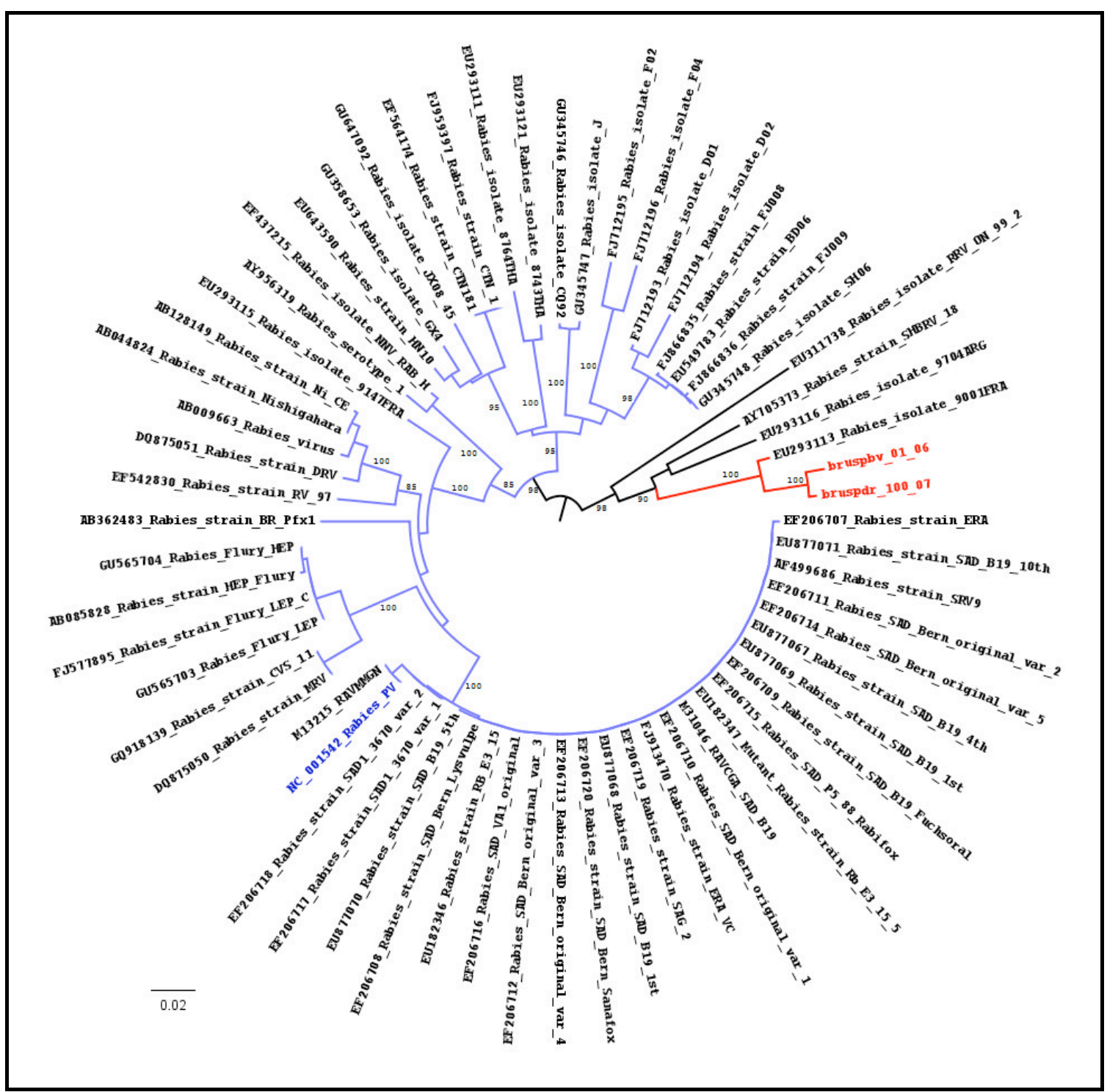

Figura 63. Árvore filogenética de máxima verossimilhança (ML) para a polimerase.

Análise parcial da amostra brdrusp100/07 (fragmento 4c), construída pelo programa MEGA 4.0 e realizada uma busca heurística (heuristic search) com o algorítmo "NJ". Os valores nos principais nós representam os valores de 10000 réplicas de bootstrap superiores a 50\%. 


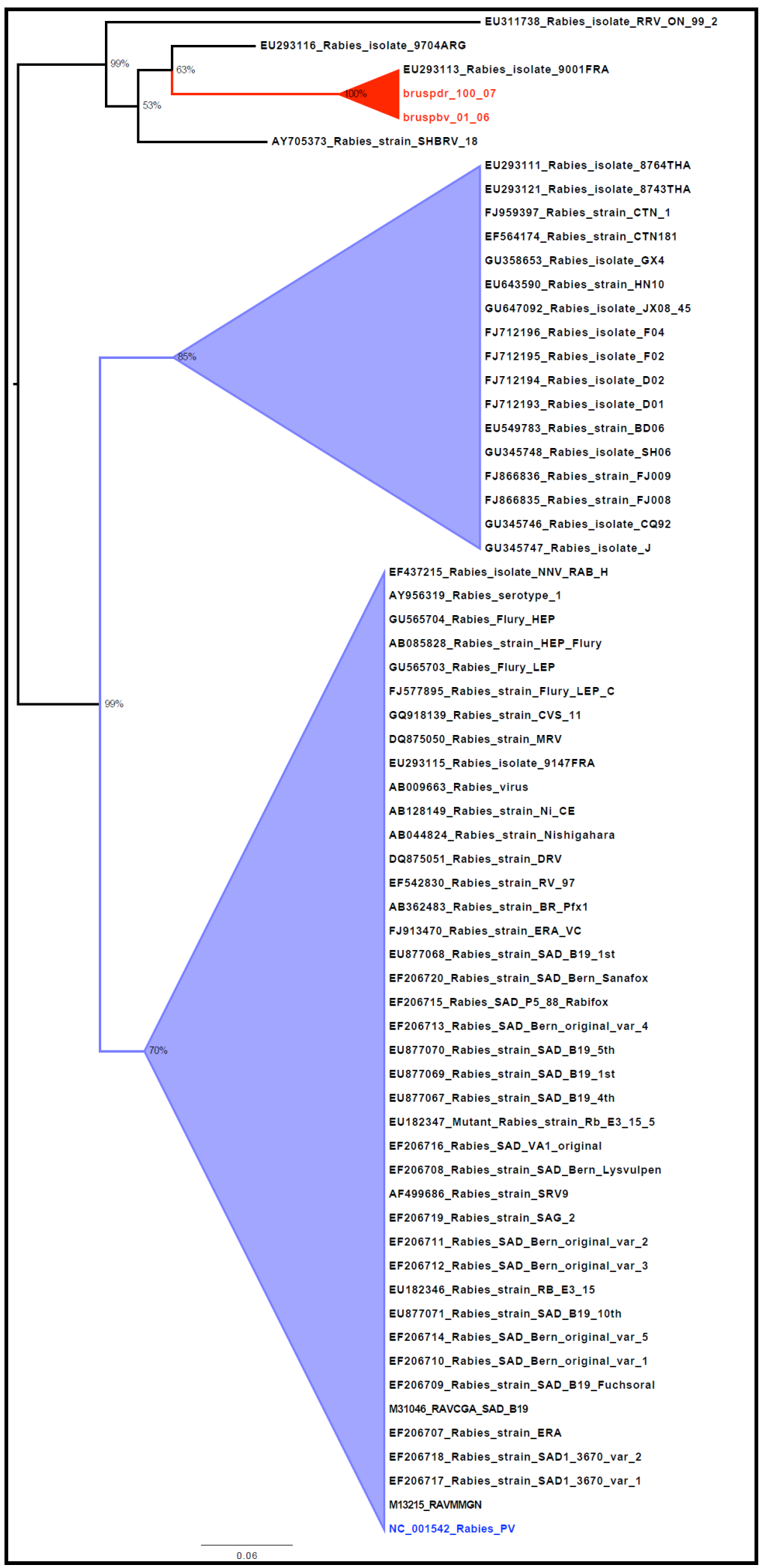

Figura 64. Árvore filogenética de máxima verossimilhança (ML) para a polimerase.

Análise parcial da amostra brdrusp100/07 (fragmento 4c), construída pelo programa GARLi e realizada uma busca heurística (heuristic search) com o algorítmo "GTR+gama+I". Os valores nos principais nós representam os valores de 1000 réplicas de bootstrap superiores a 50\%. 
Tabela 7 - Substituições de aminoácidos encontradas para a proteína $L$

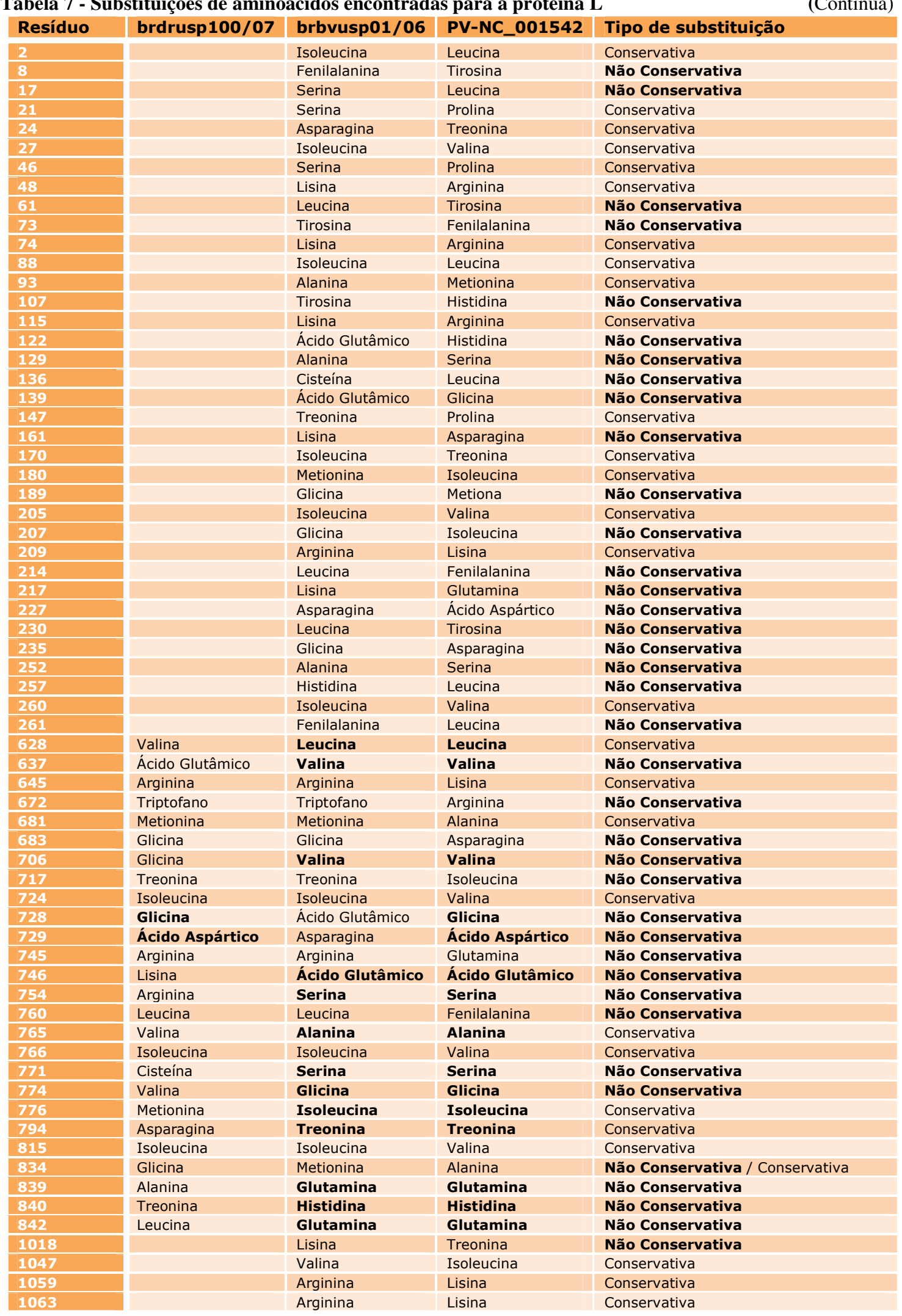


Tabela 7 - Substituições de aminoácidos encontradas para a proteína $L$

\begin{tabular}{|c|c|c|c|c|}
\hline Resíduo & brdrusp100/07 & brbvusp01/06 & PV-NC_001542 & Tipo de substituição \\
\hline 1089 & & Arginina & Glicina & Não conservativa \\
\hline 1133 & Serina & Serina & Treonina & Conservativa \\
\hline 1136 & Valina & Valina & Alanina & Não Conservativa \\
\hline 1158 & Serina & Serina & Cisteína & Não Conservativa \\
\hline 1159 & Arginina & Arginina & Treonina & Não Conservativa \\
\hline 1206 & Asparagina & Asparagina & Ácido Aspártico & Não Conservativa \\
\hline 1214 & Valina & Valina & Isoleucina & Conservativa \\
\hline 1218 & Isoleucina & Isoleucina & Valina & Conservativa \\
\hline 1321 & & Leucina & Valina & Conservativa \\
\hline 1325 & & Glicina & Ácido Aspártico & Não Conservativa \\
\hline 1327 & & Leucina & Valina & Conservativa \\
\hline 1328 & & Serina & Treonina & Conservativa \\
\hline 1336 & Ácido Aspártico & Ácido Aspártico & Ácido Glutâmico & Conservativa \\
\hline 1342 & Arginina & Arginina & Lisina & Conservativa \\
\hline 1344 & Asparagina & Asparagina & Isoleucina & Não Conservativa \\
\hline 1346 & Glicina & Arginina & Arginina & Não Conservativa \\
\hline 1348 & Glicina & Valina & Valina & Não Conservativa \\
\hline 1351 & Serina & Serina & Alanina & Não Conservativa \\
\hline 1388 & Tirosina & Serina & Tirosina & Não Conservativa \\
\hline 1399 & Serina & Tirosina & Tirosina & Não Conservativa \\
\hline 1401 & Ácido Aspártico & Glicina & Ácido Aspártico & Não Conservativa \\
\hline 1411 & Serina & Serina & Glicina & Não Conservativa \\
\hline 1476 & Leucina & Leucina & Fenilalanina & Não Conservativa \\
\hline 1478 & Glicina & Glicina & Ácido Glutâmico & Não Conservativa \\
\hline 1487 & Valina & Valina & Isoleucina & Conservativa \\
\hline 1496 & Arginina & Arginina & Lisina & Conservativa \\
\hline 1516 & Alanina & Alanina & Valina & Conservativa \\
\hline 1524 & Ácido Glutâmico & Ácido Glutâmico & Ácido Aspártico & Conservativa \\
\hline 1535 & Serina & Serina & Alanina & Não Conservativa \\
\hline 1556 & Lisina & Lisina & Arginina & Conservativa \\
\hline 1561 & Serina & Glicina & Serina & Não Conservativa \\
\hline 1564 & Treonina & Treonina & Ácido Aspártico & Não Conservativa \\
\hline 1569 & Metionina & Metionina & Leucina & Conservativa \\
\hline 1589 & Ácido Glutâmico & Ácido Glutâmico & Ácido Aspártico & Conservativa \\
\hline 1590 & Ácido Aspártico & Ácido Aspártico & Histidina & Não Conservativa \\
\hline 1617 & & Valina & Treonina & Não Conservativa \\
\hline 1619 & & Cisteína & Ácido Aspártico & Não Conservativa \\
\hline 1623 & & Serina & Asparagina & Conservativa \\
\hline
\end{tabular}


Tabela 7 - Substituições de aminoácidos encontradas para a proteína $L$

(Conclusão)

\begin{tabular}{|c|c|c|c|c|}
\hline Resíduo & brdrusp100/07 & brbvusp01/06 & PV-NC_001542 & Tipo de substituição \\
\hline 1665 & Leucina & Leucina & Fenilalanina & Não Conservativa \\
\hline 1691 & Ácido Aspártico & Glicina & Ácido Aspártico & Não Conservativa \\
\hline 1692 & Ácido Aspártico & Glicina & Ácido Aspártico & Não Conservativa \\
\hline 1693 & Leucina & Prolina & Leucina & Não Conservativa \\
\hline 1700 & Cisteína & Fenilalanina & Cisteína & Não Conservativa \\
\hline 1702 & Ácido Glutâmico & Valina & Valina & Não Conservativa \\
\hline 1708 & Cisteína & Glicina & Glicina & Conservativa \\
\hline 1714 & Leucina & Valina & Valina & Conservativa \\
\hline 1722 & Arginina & Arginina & Lisina & Conservativa \\
\hline 1736 & Valina & Alanina & Alanina & Conservativa \\
\hline 1746 & Ácido Glutâmico & Alanina & Alanina & Não Conservativa \\
\hline 1749 & Serina & Serina & Arginina & Não Conservativa \\
\hline 1752 & Ácido Aspártico & Ácido Aspártico & Histidina & Não Conservativa \\
\hline 1755 & Isoleucina & Isoleucina & Valina & Conservativa \\
\hline 1765 & Glicina & Triptofano & Triptofano & Não Conservativa \\
\hline 1775 & Treonina & Treonina & Alanina & Não Conservativa \\
\hline 1778 & Arginina & Arginina & Lisina & Conservativa \\
\hline 1785 & Ácido Glutâmico & Ácido Glutâmico & Lisina & Não Conservativa \\
\hline 1789 & Metionina & Treonina & Metionina & Conservativa \\
\hline 1801 & Alanina & Treonina & Treonina & Não Conservativa \\
\hline 1812 & Glutamina & Leucina & Leucina & Não Conservativa \\
\hline 1819 & Alanina & Serina & Serina & Não Conservativa \\
\hline 1820 & Lisina & Isoleucina & Isoleucina & Não Conservativa \\
\hline 1821 & Serina & Ácido Aspártico & Ácido Aspártico & Não Conservativa \\
\hline 1839 & Ácido Aspártico & Ácido Aspártico & Asparagina & Não Conservativa \\
\hline 1844 & Prolina & Glutamina & Glutamina & Não Conservativa \\
\hline 1845 & Alanina & Histidina & Histidina & Não Conservativa \\
\hline 1846 & Metionina & Leucina & Leucina & Conservativa \\
\hline 1847 & Alanina & Serina & Serina & Não Conservativa \\
\hline 1852 & Valina & Valina & Serina & Não Conservativa \\
\hline 1860 & & Metionina & Valina & Conservativa \\
\hline 1889 & & Alanina & Treonina & Não Conservativa \\
\hline 1929 & & Histidina & Asparagina & Não Conservativa \\
\hline 1934 & & Arginina & Metionina & Não Conservativa \\
\hline 1949 & & Prolina & Histidina & Não Conservativa \\
\hline 1961 & & Alanina & Treonina & Não Conservativa \\
\hline 1966 & & Serina & Alanina & Não Conservativa \\
\hline 1972 & & Treonina & Metionina & Não Conservativa \\
\hline 1974 & & Isoleucina & Valina & Conservativa \\
\hline 1981 & & Treonina & Asparagina & Não Conservativa \\
\hline 2035 & Alanina & Treonina & Treonina & Não Conservativa \\
\hline 2039 & Metionina & Metionina & Arginina & Não Conservativa \\
\hline 2044 & Arginina & Arginina & Leucina & Não Conservativa \\
\hline 2047 & Treonina & Treonina & Valina & Não Conservativa \\
\hline 2055 & Ácido Aspártico & Ácido Aspártico & Asparagina & Não Conservativa \\
\hline 2057 & Alanina & Alanina & Treonina & Não Conservativa \\
\hline 2058 & Alanina & Alanina & Serina & Não Conservativa \\
\hline 2065 & Cisteína & Arginina & Cisteína & Não Conservativa \\
\hline 2087 & Treonina & Arginina & Arginina & Não Conservativa \\
\hline 2089 & Arginina & Arginina & Valina & Não Conservativa \\
\hline 2091 & Arginina & Arginina & Serina & Não Conservativa \\
\hline 2093 & Ácido Glutâmico & Ácido Glutâmico & Lisina & Não Conservativa \\
\hline 2097 & Lisina & Lisina & Glicina & Não Conservativa \\
\hline 2101 & Lisina & Lisina & Arginina & Conservativa \\
\hline 2104 & Arginina & Arginina & Histidina & Não Conservativa \\
\hline 2107 & Asparagina & Treonina & Asparagina & Não Conservativa \\
\hline 2111 & Treonina & Serina & Serina & Conservativa \\
\hline 2113 & Lisina & Lisina & Ácido Glutâmico & Não Conservativa \\
\hline 2114 & Ácido Aspártico & Ácido Aspártico & Asparagina & Não Conservativa \\
\hline 2126 & Cisteína & Serina & Cisteína & Não Conservativa \\
\hline
\end{tabular}

A tabela 7 mostra o perfil de substituição de aminoácidos para esta região da proteína L. Foram encontradas 93 substituições não conservativas na amostra em brbvusp01/06 (onde 39 substituições foram identificadas em regiões sequenciadas apenas para a amostra 
brbvusp01/06 e outras 14 substituições foram identificadas apenas para brbvusp01/06) e 66 substituições não conservativas na amostra brdrusp100/07 (onde 26 substituiçoes foram identificadas apenas em brdrusp100/07) quando comparadas à amostra de referência PV (NC_001542) sendo 40 substituições não conservativas comuns para as amostras brbvusp01/06 e brdrusp100/07.

Dezessete resíduos de aminoácidos da polimerase viral foram identificados como próprios da variante mantida por morcegos hematófagos. Quatorze resíduos com substituições não conservativas: resíduo 8 com Fenilalanina (Figura 65a), 139 com um Ácido Glutâmico, 217 com uma Lisina, 683 com uma Glicina, 1092 com uma Treonina, 1139 com uma Arginina, 1255 com uma Alanina, 1617 e 1619 com uma Valina e Cisteína respectivamente, 1852 com uma Valina, 1889 com uma Alanina, 2057 e 2058 com Alanina e 2089 com uma Arginina; e três resíduos com substituições conservativas: 645 com Arginina (Figura 65b), 1214 com Valina e 1336 com Ácido Aspartico. Outros 13 resíduos 24, 27 (Figura 65c), 61, 122, 170, 1144, 1342, 1374, 1487 (Figura 65d), 1556, 1653, 1665 e 2101 foram relacionados ao ciclo aéreo de transmissão e tês resíduos 21, 88 (Figura 65e) e 107 foram comuns para as variantes relacionadas à $D$. rotundus e $T$. brasiliensis.

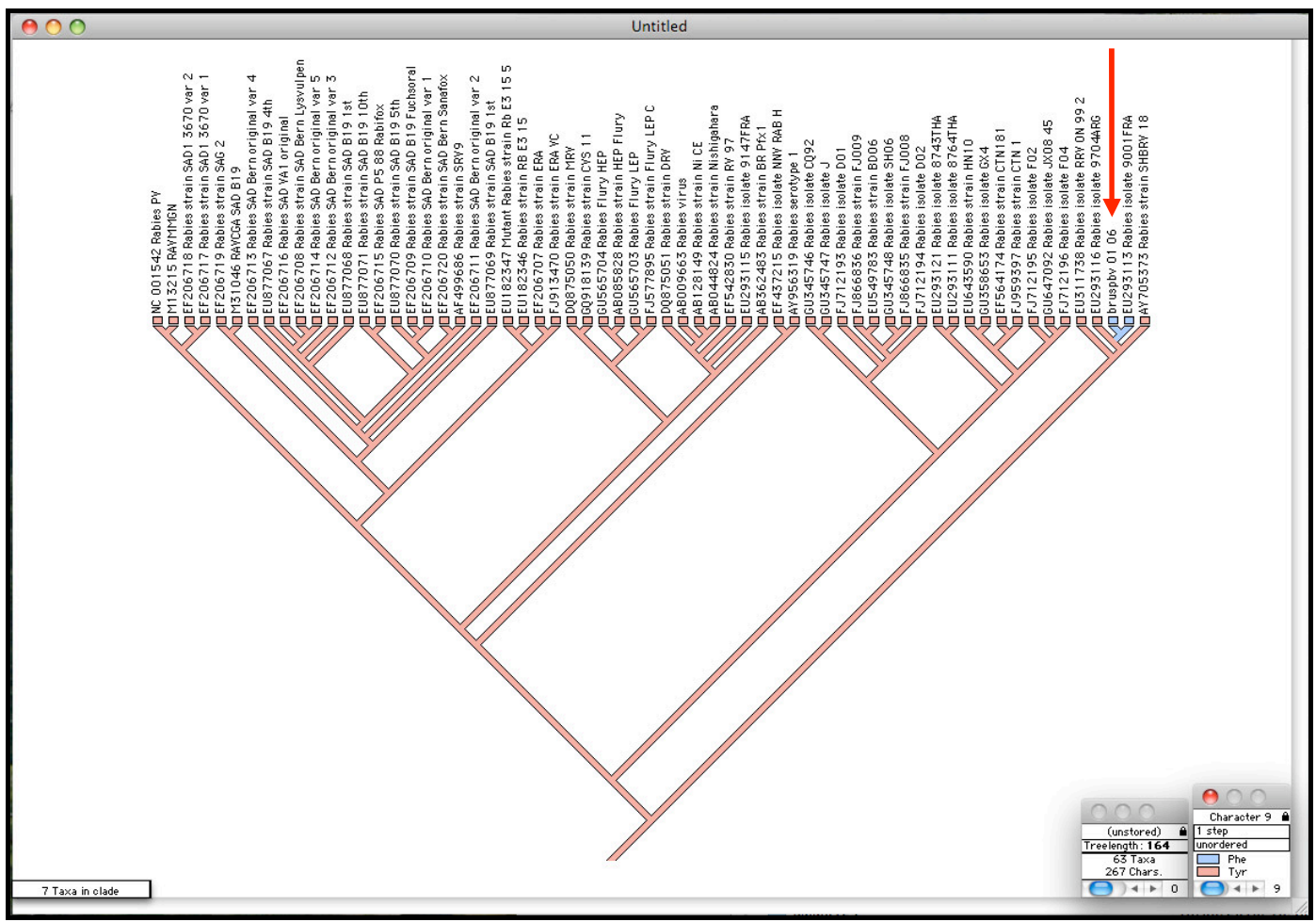

Figura 65a.Ilustração gerada pelo programa MacClade para o resíduo 8 da polimerase viral. Em azul claro pode ser vista a Fenilalanina para as amostras com variante genética mantida por morcegos hematófagos Desmodus rotundus entre elas a amostra brbvusp01/06 e a Tirosina para as demais amostras. 


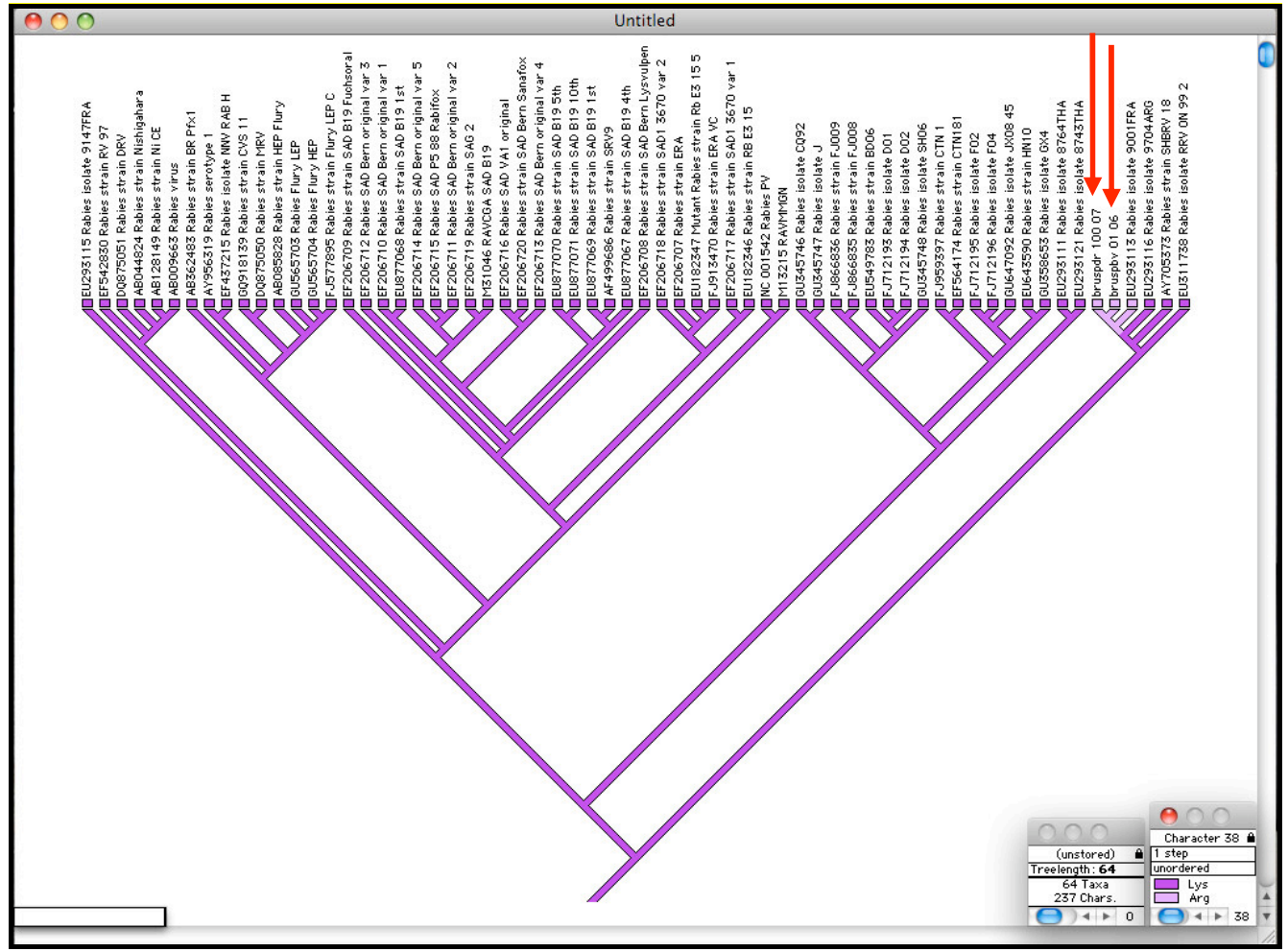

Figura 65b. Ilustração gerada pelo programa MacClade para o resíduo 645 da polimerase.

Em rosa claro pode ser vista a Arginina para as amostras do ciclo mantido por morcegos hematófagos entre elas, identificadas com setas vermelhas, as amostras brbvusp01/06 e brdrusp100/07 e a Lisina para as demais amostras.

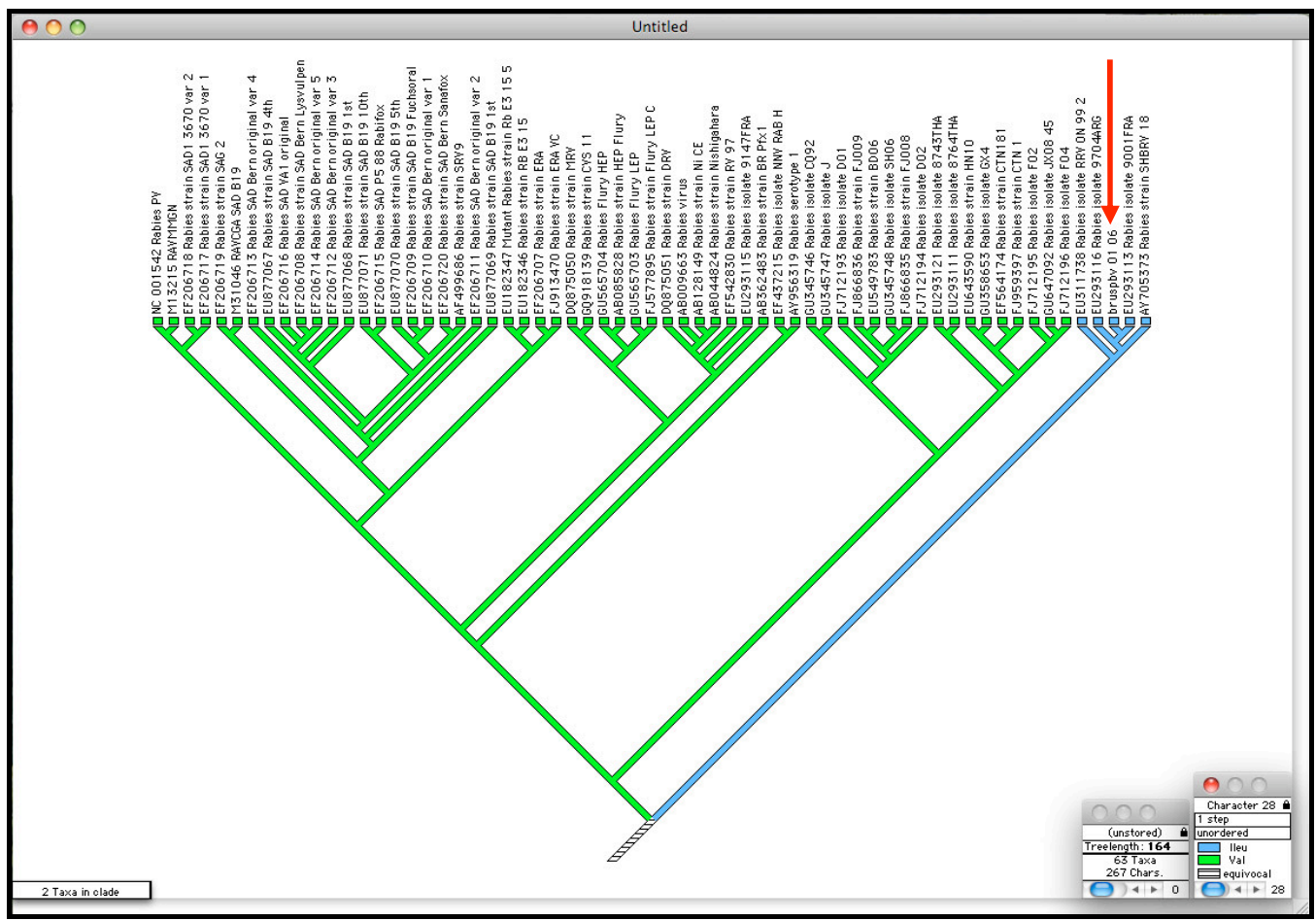

Figura 65c. Ilustração gerada pelo programa MacClade para o resíduo 27 da polimerase.

Em azul pode ser vista a Isoleucina para as amostras do ciclo aéreo incluindo as amostras brbvusp01/06 e EU311738 (raccoon) e a Valina para as demais amostras. 


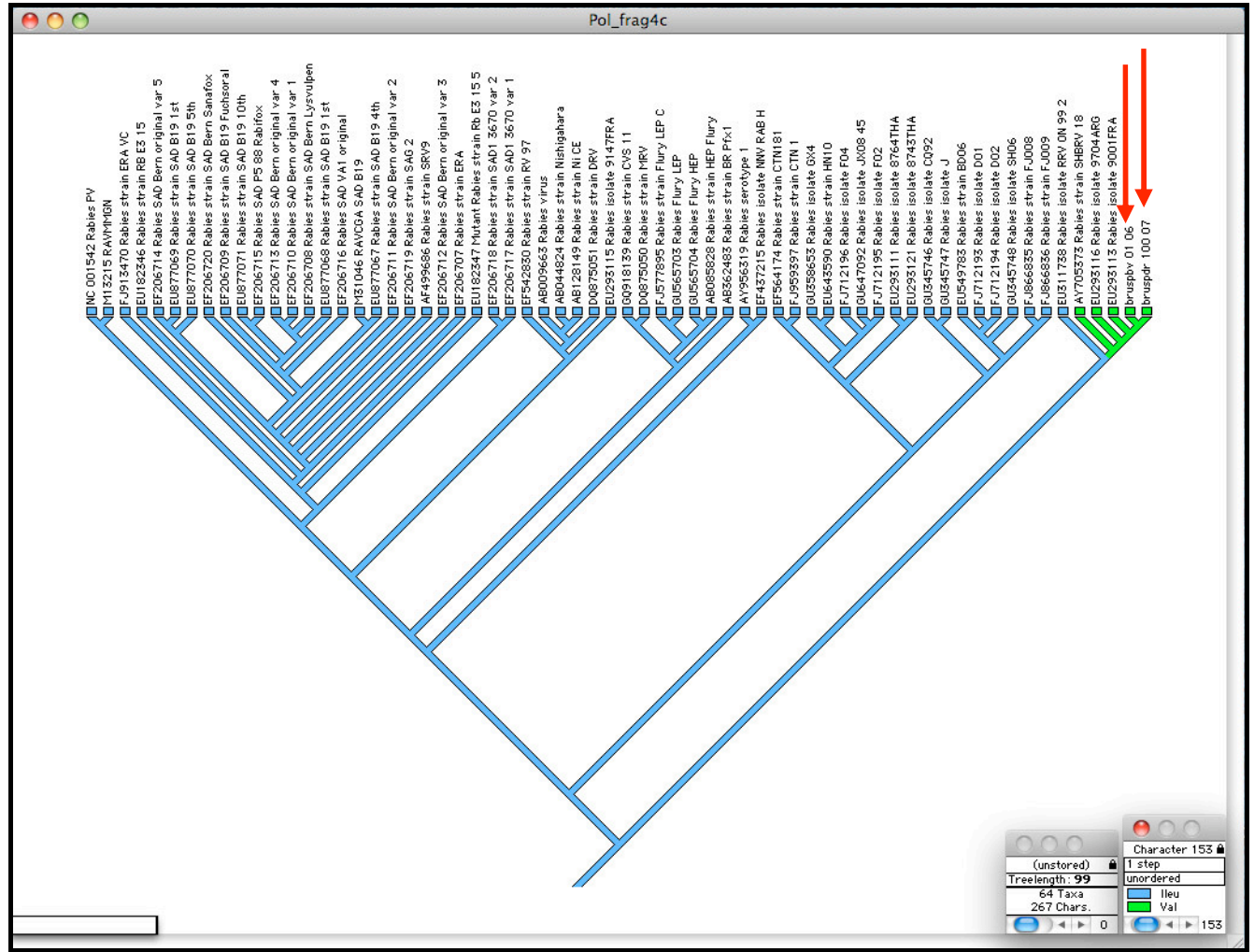

Figura 65d. Ilustração gerada pelo programa MacClade para o resíduo 1487 da polimerase.

Em verde pode ser vista a Valina para as amostras do ciclo aéreo incluindo as amostras brbvusp01/06 e brdrusp100/07 e a Isoleucina para as demais amostras.

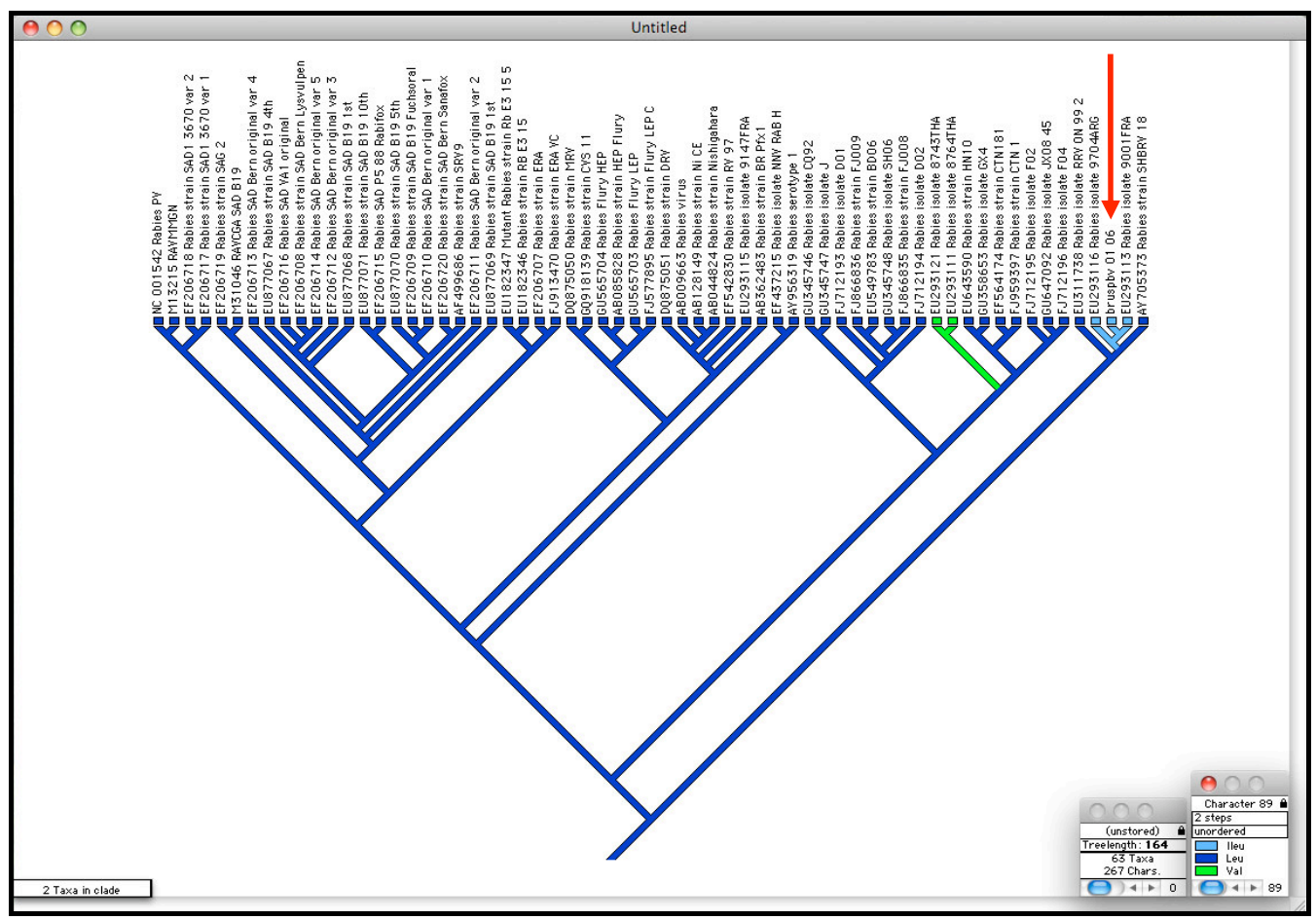

Figura 65e. Ilustração gerada pelo programa MacClade, no resíduo 88 da polimerase.

Em azul claro pode ser vista a Isoleucina para as amostras da variante mantida por morcegos Desmodus rotundus e morcegos Tadarida brasiliensis. A seta indica a amostra brbvusp01/06. 
Foram identificados trinta e sete sítios conservados com sete ou mais resíduos de aminoácidos ao se comparar as amostras estudadas com a amostra de referência PV. Para a amostra brbvusp01/06 três sítios conservados no fragmento 1, um no fragmentos 2, dezesseis no fragmento 3 e dezessete no fragmento 4, enquanto para a amostra brdrusp100/07 foram identificados um sítio no fragmento $2 \mathrm{a}$, cinco no fragmento $3 \mathrm{a}$, onze no fragmento $4 \mathrm{a}$ e um no fragmento $4 \mathrm{~b}$. A tabela 8 mostra as trinta e sete regiões dos fragmentos parciais do gene $\mathrm{L}$ analisados com mais de sete resíduos de aminoácidos extremamente conservadas para as amostras estudadas que correspondem aos domínios conservados da polimerase viral.

Tabela 8 - Regiões com mais de sete resíduos de aminoácidos conservados entre as amostras estudadas e a amostra de referência $P V$ - proteína $L$

\begin{tabular}{|c|c|c|}
\hline Resíduos & Domínio & Localização \\
\hline 28 a 45 & PNILRNSDYNLNSPLIED & \multirow{3}{*}{ Fragmento 1} \\
\hline 182 a 188 & LYMNALD & \\
\hline 236 a 251 & CLFDRNYTLMLKDLFL & \\
\hline 595 a 605 & KLIDRVTGQGL & Fragmentos 2 e $2 \mathrm{a}$ \\
\hline 617 a 626 & LDYEKWNNHQ & \multirow{11}{*}{ Fragmento 3} \\
\hline 646 a 656 & RVFSRTHEFFQ & \\
\hline 708 a 716 & LLMIDRESQ & \\
\hline 730 a 742 & NQVLCPTYMLSPGLS & \\
\hline 778 a 793 & KKEETMCSYDFLIYGK & \\
\hline 795 a 809 & PLFRGNILVPESKRW & \\
\hline 976 a 992 & TILLKDAIRKALYDEVD & \\
\hline 996 a 1017 & NSEFREAILLSKTHRDNFILFL & \\
\hline 1021 a 1042 & EPLFPRFLSELFSSSFLGIPES & \\
\hline 1048 a 1057 & QNSRTIRRQF & \\
\hline 1104 a 1122 & ISWGRKVVGTTVPHPSEML & \\
\hline 1163 a 1189 & KGYLGSSTSMSTQLFHAWEKVTNVHVV & \multirow{5}{*}{ Fragmentos 3 e $3 a$} \\
\hline 1194 a 1202 & SLKESINWF & \\
\hline 1232 a 1241 & VFKRTGSALH & \\
\hline 1258 a 1268 & PNLLSHISVST & \\
\hline 1116 a 1122 & PHPSEML & \\
\hline 1414 a 1424 & SPRDYLRGLAR & \multirow{11}{*}{ Fragmentos 4 e $4 \mathrm{a}$} \\
\hline 1432 a 1442 & ICFLTRMTNIN & \\
\hline 1451 a 1468 & SGVISYILLRLDNHPSLY & \\
\hline 1479 a 1486 & EIFSIPQK & \\
\hline 1503 a 1514 & LCYLQHVLRYER & \\
\hline 1517 a 1523 & ITASPEN & \\
\hline 1525 a 1534 & WLWIFSDFRS & \\
\hline 1542 a 1551 & LITYQSHLLL & \\
\hline 1571 a 1583 & SLMRQVLGGHGED & \\
\hline 1604 a 1613 & WVDQEVRHAA & \\
\hline 1668 a 1690 & PLISGLRVVQWATGAHYKLKPIL & \\
\hline 1723 a 1735 & LVFNSLLEVNDLM & Fragmentos $4 \mathrm{e} 4 \mathrm{~b}$ \\
\hline 1862 a 1871 & SSFSSELYLR & \multirow{5}{*}{ Fragmento 4} \\
\hline 1873 a 1888 & SKRGKFFRDAEYLTSS & \\
\hline 1891 a 1903 & REMSLVLFNCSSP & \\
\hline 1905 a 1923 & SEMQRARSLNYQDLVRGFP & \\
\hline 1950 a 1959 & KMVDDLELQR & \\
\hline
\end{tabular}


As sequências completas e parciais obtidas durante este estudo foram depositadas no GenBank (Banco de Dados de maior reconhecimento e consulta na área) sob os números de entrada bankit1314795 (GU592648 - N de D. rotundus), bankit1314806 (GU592649 N do bovino), bankit1314810 (GU592650 - P do bovino), bankit1314811 (GU592651 - M do bovino), bankit1314814 (GU592652 - G do bovino), bankit1436469 (P de D. rotundus), bankit1436471 (M de D. rotundus), bankit1436472 (G de D. rotundus), bankit1314818 (GU592653 - psi do bovino), bankit1314820 (GU592654 - L parcial do bovino). 


\section{DISCUSSÃO}

Enquanto a amostra eleita para o estudo brdrusp100/07 estava sendo cultivada para obtenção do lote de primeira passagem em sistema de cultivo celular, uma amostra isolada de cérebro de um bovino positivo para raiva brbvusp01/06, que foi cacacterizada antigenicamente como mantida por morcegos hematófagos D. rotundus, por meio de imunofluorescência indireta, foi utilizada para dar início aos testes de padronização e foi utilizada como amostra controle.

Ambas as amostras foram processadas por imunofluorescência indireta com a utilização do painel de anticorpos monoclonais (CDC/OPAS - PAHO) e por técnicas de biologia molecular seguida de estudo filogenético comparativo de fragmento da nucleoproteína $\mathrm{N}$, com a finalidade de caracterização antigênica e genética dos isolados.

Com a utilização de um painel de anticorpos monoclonais (PAHO, 2000), as duas amostras de vírus da raiva utilizadas, a amostra isolada de bovino brbvusp01/06 (amostra teste para padronização) e a amostra em estudo brdrusp100/07, isolada de D. rotundus, foram caracterizadas antigênicamente como variante antigênica 3 (AgV3) cujo perfil de reação observado confere com o padrão de reação estabelecido pelo painel utilizado (Favoretto et al., 2002).

Tanto para a amostra isolada de bovino (brbvusp01/06) quanto para a amostra em estudo (brdrusp100/07), o conjunto de reações observado contra o painel de anticorpos monoclonais anti-nucleoproteína viral identificou a presença da $\mathrm{AgV} 3$, característica de vírus mantido pelo morcego hematófago $D$. rotundus previamente relacionada ao hospedeiro e reservatório descrito nas Américas e particularmente no Brasil (Smith et al., 1992; Mattos et al., 1999; Velasco-Villa et al., 2002; Favi et al., 2002; Favoretto et al., 2002).

A utilização de anticorpos monoclonais tornou possível a observação precisa das diferenças antigênicas, com distinção em sorotipos e subtipos (Sacramento et al., 1991). Esta metodologia vem sendo utilizada por países de todas as regiões do mundo e particularmente nas Américas, onde há mais de dez anos o painel de anticorpos monoclonais utilizado está bem estabelecido, auxiliando na caracterização das variantes de isolados do vírus, identificando muitas vezes o reservatório envolvido.

A análise do gene codificador para a nucleoproteína, por ser uma região extremamente conservada e sintetizada em grande quantidade durante a infecção viral (Banerjee, 1987) permitiu a caracterização genética, uma vez que as amostras estudadas segregaram com outras amostras relacionadas à variante mantida por populações de morcegos hematófagos $D$. 
rotundus. A amplificação do gene $\mathrm{N}$ permite um método de genotipagem precisa baseado na sequência de nucleotídeos (Sacramento et al., 1991). A sequência nucleotídica da proteína $\mathrm{N}$ tem sido muito estudada em isolados representativos de todos as espécies virais (antigos genótipos) de Lyssavirus e encontra-se disponível em bancos de dados, permitindo estudos de diversidade genética do vírus da raiva que circula na maioria dos continentes (Bourhy et al., 1993; Kissi et al., 1995; Bandrane e Tordo, 2001).

As análises do fragmento de 320 nucleotídeos compreendidos entre as posições $1157 \mathrm{e}$ 1476 da região carboxi-terminal do gene $\mathrm{N}$ foram realizadas para a determinação da variante genética, uma vez que este papel ainda não foi definido para outras proteínas virais. A análise filogenética do fragmento carboxi-terminal da núcleoproteína $\mathrm{N}$ revelou que as duas amostras estudadas pertencem à espécie viral Rabies virus (antigo genótipo 1) e segregam em um grupo de vírus mantidos por populações de morcegos hematófagos $D$. rotundus.

O sequenciamento foi realizado utilizando a metodologia de primer walking, previamente descrita por Tordo et al. (1986b) e Ito et al. (2001b) que, embora tenha se mostrado mais trabalhosa que os kits comerciais, se mostrou eficiente e acessível. A padronização da metodologia foi realizada em uma primeira etapa do estudo. Como os oligonucleotídeos foram degenerados, uma vez que não haviam sequências completas relacionadas à linhagem genética estudada disponíveis no GenBank no momento de desenho dos primers para a amplificação da variante associada ao morcego hematófago $D$. rotundus, foram utilizados fragmentos menores com o intuito de buscar produtos amplificados de melhor qualidade. As sequências obtidas foram utilizadas como fonte de informações para estabelecer os possíveis padrões de diferenciação de acordo com a região do genoma identificada pelo sequenciamento.

O gene codificador para a nucleoproteína das amostras em estudo brbvusp01/06 (controle bovino) e brdrusp100/07 (morcego hematófago) foram sequenciados e analisados e quando comparados com o grupo de amostras pertencentes a reservatórios terrestres, segregaram em um grupo independente, enquanto que, quando comparado com amostras de morcegos $D$. rotundus ou amostras isoladas de animais, cujas histórias descrevem agressão por este morcego hematófago, procedentes das Américas, apresentou altos valores de similaridade entre as sequências (Bootstrap: 100\%) demonstrando que pertencem ao grupo de amostras relacionadas a este reservatório e indicando que estas amostras pertencem ao mesmo ciclo de transmissão (Figura 25).

Técnicas moleculares têm permitido verificar uma grande diversidade entre as sequências nucleotídicas obtidas de isolados do vírus da raiva. Estudos demonstrando esta 
diversidade foram realizados tanto em regiões geograficamente restritas como no Canadá (Nadin-Davis et al., 1993, 1994), na França (Sacramento et al., 1992), na Venezuela (de Mattos et al., 1996), no México (Mattos et al., 1999; Loza-Rubio et al., 1999; Velasco-Villa et al., 2002); no Chile (Yung et al., 2002), na Bolívia (Favi et al., 2003), na Argentina (Cisterna et al., 2005) e no Brasil (Favoretto et al., 2001; Kobayashi et al., 2005; Favoretto et al., 2006; Carnielli et al., 2006, 2008, 2009a, 2009b) ou ainda em países da África, da Ásia, outros países da Europa e das Américas (Smith et al., 1992; Markotter et al., 2008; McElhinney et al., 2008; Johnson et al., 2009; Singer et al., 2009; Wu et al., 2009; Gong et al., 2010; Hirano et al., 2010; Van Zyl et al., 2010).

Nos estudos de genotipagem com a nucleoproteína, uma amostra recentemente descrita por Delmas et al. (2008) de um cachorro da Guiana (EU293113), a única relacionada à variante em estudo, sequenciada completamente e disponível no GenBank, segregou junto com as amostras brbvusp01/06 isolada de um bovino e brdrusp100/07 isolada de um morcego hematófago ambas relacionadas à variante genética mantida por morcegos hematófagos $D$. rotundus. Em sua publicação Delmas et al. (2008) apresentam o histórico de que o cão havia sido agredido por um morcego sem identificação, impedindo o acesso a importante informação sobre o fato do morcego ser hematófago ou não, sendo o foco do trabalho apenas o mapeamento e comparação entre os lissavírus sem qualquer referência à variante genética da amostra em questão.

A tabela 3 apresentou as 21 substituições de aminoácidos observadas na nucleoproteína, encontradas quando as amostras brbvusp01/06 e brdrusp100/07 foram comparadas à amostra de referência PV (NC_001542), confirmando ser a nucleoproteína como a mais conservada do vírus (Marston et al., 2007). Destas 21 substituições, nove $(42,8 \%)$ e dez $(47,6 \%)$ foram não conservativas para a amostra brbvusp01/06 (bovino) e para a amostra brdrusp100/07 (morcego) respectivamente.

O domínio LGKAPDLNKAYKS situado entre os resíduos 43 a 55 se apresentou altamente conservado para todas as sequências utilizadas no dataset de comparação com excessão das amostras brasileiras estudadas brdrusp100/07 e brbvusp01/06. Doze domínios de 7 a 21 resíduos de aminoácidos (domínios EYKYPAI entre os resíduos 27 a 33, LGKAPDL entre os resíduos 43 a 49, VEGNWALTGG entre os resíduos 116 a 125, SLYRLSKISGQ entre os resíduos 146 a 156, VEHHTLMTTHKMCANW entre os resíduos 182 a 197 e VVTAYEDCSGLVSFTGF entre os resíduos 229 a 245, KQINLTA entre os resíduos 247 a 253, PHSYFIHFRSLGLSGKSPYSS entre os resíduos 282 a 302, FNLIHFVGCYMG entre os resíduos 309 a 320, CAPHEMSVLGGY entre os resíduos 333 a 344, GTFERRF entre os 
resíduos 353 a 359 e ALADDGTV resíduos 380 a 387) foram identificados como altamente conservados para todas as sequências de amostras utilizadas para comparação.

Testes com os oligonucleotídeos iniciadores foram realizados para complementar a nucleoproteína $(\mathrm{N})$ e amplificar fosfoproteína $(\mathrm{P})$ e proteína de matriz $(\mathrm{M})$ simultaneamente. Os resultados obtidos foram satisfatórios como pode ser observado na figura 8 (para P e M), sendo que os melhores resultados foram obtidos a partir da amplificação de fragmentos únicos, como esperado, uma vez que dispensa a etapa de purificação anterior ao sequenciamento.

O estudo da fosfoproteína da variante mantida por morcegos hematófagos D. rotundus apresentou uma região codante de 894 nucleotídeos (297 aminoácidos e um códon de terminação), como observado na amostra de referência PV (Tordo et al., 1986b) e em outras amostras disponíveis no GenBank (Nadin-Davis et al., 1997; Kobayashi et al., 2007). Ao serem realizadas as análises filogenéticas observamos que as amostras com variante genética mantida por morcegos hematófagos D. rotundus (classificação padronizada de acordo com análises da nucleoproteína), segregaram num mesmo clado para a fosfoproteína (Figuras 31 e 32) confirmando a classificação já descrita na literatura para a proteína N. Ao serem analisadas as amostras pertencentes a este clado foi observado que a porção inicial da fosfoproteína que compreende do aminoácido 1 (códon inicial - metionina) ao aminoácido 46 é altamente conservada, como já observado por Kobayashi et al., (2007) com excessão de apenas dois resíduos (29 e 42) nos quais todas as amostras da variante mantida por $D$. rotundus apresentaram substituição dos aminoácidos Asparagina na amostra PV por uma Alanina, Ácido Glutâmico na amostra PV por Ácido Aspártico. Para o clado das amostras pertencentes à variante genética mantida por morcegos hematófagos $D$. rotundus as regiões compreendidas entre os aminoácidos 80 a 125 (exceto os resíduos 85 e 91 para a amostra AF369359 - T. brasiliensis), 179 a 221 (exceto para a posição 189 da amostra AF369359 - T. brasiliensis) e 258 a 294 também foram muito conservadas, enquanto que, ao se comparar as amostras em estudo com as demais amostras disponíveis no banco de dados observamos que o domínio compreendido entre os aminoácidos 41 a 195 é a região onde aparece maior número de substituições de aminoácidos com apenas duas pequenas regiões dentro deste domínio, altamente conservadas para todas as amostras (do resíduo 43 a 47 - PIEVD e 113 a 118 RFLKIW).

O domínio rico em lisina FSKKYKF na fosfoproteína descrito por Kobayashi et al. (2007) e identificado como um importante componente de binding da região C-terminal da proteína $\mathrm{N}$ também se apresentou conservado para as amostras pertencentes ao clado da 
variante genética mantida por morcegos hematófagos $D$. rotundus. Na tabela 4 estão as 52 substituições de aminoácidos localizadas quando as amostras brbvusp01/06 e brdrusp100/07 foram comparadas à amostra de referência PV (NC_001542). Destas 52 substituições, mais da metade (31) foram do tipo não conservativa, ou seja, a mudança se deu por aminoácidos de classes diferentes.

Confirmando Kobayashi et al., (2007) também pudemos observar na posição do aminoácido 145 uma Alanina conservada para amostras pertencentes ao ciclo aéreo e uma Serina conservada para amostras do ciclo terrestre. A Met na posição 20 e as Serinas conservadas nas posições 210 e 271, alvo fosfoaceptor, descritas por Nadin-Davis et al., (2002) também foram observadas neste estudo. Os resíduos Ser $_{68}$ e Gly 112 foram identificados como padrões de substituição de aminoácidos próprios da variante mantida por morcegos hematófagos D. rotundus. Os resíduos $\mathrm{Ala}_{136}, \mathrm{Val}_{153}, \mathrm{Lys}_{158}, \mathrm{Val}_{178}$ foram identificados apenas no clado onde segregaram as amostras pertencentes à variante mantida por morcegos hematófagos D. rotundus, porém as amostras AF369359 - T. brasiliensis, AF369362 - D. rotundus e AF369363 - D. rotundus apresentaram outras substituições nestes resíduos (todos os resíduos na amostra AF369359, sítio 158 na amostra AF369362 e sítio 178 na amostra AF369363).

O domínio MQDDC entre os resíduos 287 a 291 foi conservado em todas as amostras como também observado por Cibulski et al., (2010, comunicação pessoal in Encontro Nacional de Virologia 2010 - dados ainda não publicados) ${ }^{3}$. A fosfoproteína participa da atividade de replicação do vírus e interage com a polimerase viral (Nadin-Davis et al., 1997) sendo, portanto, necessária uma atenção maior a esta região variável encontrada.

A proteína de matriz, localizada dentro do envelope viral e com interação direta junto à região citoplasmática da glicoproteína, possui uma região codante de 609 nucleotídeos (202 aminoácidos e um códon de terminação), estando associada com a citotoxicicidade em células BHK infectadas com linhagens vacinais (Mita et al., 2008), com a transcrição viral (NadinDavis et al., 1997) e com a indução de apoptose celular associada com a glicoproteína (Faber et al., 2002). Assim como a núcleoproteína e fosfoproteína, a proteína de matriz também confirmou a classificação genética para variante mantida por morcegos hematófagos $D$. rotundus (Figuras 36 e 37). Com a análise dos aminoácidos da proteína de matriz (Tabela 5) foi possível observar as substituições de aminoácidos, 26 substituições quando a amostra brbvusp01/06 foi comparada à amostra de referência PV (NC_001542) e 21 substituições

\footnotetext{
${ }^{3}$ Cibulski S. Gramado, RS, 2010 (Encontro Nacional de Virologia).
} 
quando a análise foi realizada para a amostra brdrusp100/07, sendo 20 substituições comuns para as ambas as amostras. Destas 26 substituições 11 foram do tipo não conservativa para a amostra brbvusp01/06, das 21 substituições 8 foram do tipo não conservativa para a amostra brdrusp100/07 e das 20 substituições em comum 6 foram do tipo não conservativas.

Substituições de aminoácidos foram encontradas nas posições 7 (Met), 22 (Ile), 80 (Asn), 82 (Leu), 148 (Ala), 184 (Leu) e 192 (Asp) confirmando Kobayashi et al. (2007). O resíduo $\mathrm{Met}_{7}$ foi observado para a variante mantida por morcegos hematófagos e apenas para a amostra EF542830 (linhagem vacinal RV 97 - ciclo terrestre de transmissão). O resíduo $\mathrm{Asn}_{80}$ também foi identificado apenas para esta variante e para as amostras DQ875050 (linhagem vacinal MRV - ciclo terrestre de transmissão) e GQ918139 (vírus fixo CVS-11 ciclo terrestre de transmissão). O resíduo $\mathrm{Ile}_{22}$ foi observado para a amostra EU293116 (morcego insetívoro T. brasiliensis) e para variante mantida por D. rotundus com excessão da amostra estudada brdrusp100/07 (morcego). Este resíduo apresentou ainda diferentes substituições (Alanina e Metionina além da Valina presente na amostra PV) para as demais amostras componentes do dataset de análise.

Os resíduos $\mathrm{Leu}_{82}, \mathrm{Ala}_{148}, \mathrm{Leu}_{184}$ e Asp 192 foram particulares para a variante genética mantida por morcegos hematófagos, sendo que todas as quatro substituições específicas observadas foram do tipo conservativa.

O resíduo $\operatorname{Gln}_{87}$ foi identificado apenas para o ciclo aéreo de transmissão. As posições dos resíduos 82, 148 e 184 podem ser visualizadas nas figuras 38a, b e c. Os domínios DLWLPPPEY resíduos 30 a 38, PNGYSF resíduos 64 a 69, NWVYKLRRT resíduos 111 a 119 e IFQWADSRGPLEGEELE resíduos 121 a 137, com exceção da amostra brbvusp01/06 que apresenta uma substituição no residuo 126 (Ácido Aspártico), foram conservados para todas as amostras analisadas. Estes dois últimos domínios estão inseridos no segmento de ligação à glicoproteína que abrange os resíduos 115 a 151, fato também observados por Cibulski-2010 (comunicação pessoal) ${ }^{4}$.

Foi localizado o domínio rico em prolina (PPPxY) entre os aminoácidos 34 ao 38, envolvido no brotamento, descrito por Harty et al (1999 e 2001) e também citado por Kobayashi et al. (2007). Nas posições 29 (Asp) e 95 (Val) descritas por Shimizu et al. (2006), também abordadas por Mita et al. (2008) para linhagens vacinais. A proteína de matriz da amostra brbvusp01/06, assim como as demais amostras selvagens disponíveis no banco de dados, não apresentou substituição de aminoácidos nestas posições (29 e 95).

\footnotetext{
${ }^{4}$ Cibulski S. Gramado, RS, 2010 (Encontro Nacional de Virologia).
} 
O domínio hidrofóbico da proteína de matriz, compreendido entre os resíduos 89 a 107 (MIGLVKVVV), foi altamente conservado para as amostras do ciclo aéreo, que segundo Tordo et al. (1986a), este sítio provavelmente é o responsável pela interação do vírus com a membrana da célula hospedeira.

Em virtude da grande importância da nucleoproteína e da glicoproteína, onde estão situados os 3 sítios antigênicos do vírus da raiva, as proteínas fosfoproteína e de matriz são pouco estudadas (Nadin-Davis et al., 1997), apesar do importante papel que cada uma delas desempenha para o vírus.

A glicoproteína foi completamente sequenciada e apresentou 1575 nucleotídeos e 525 aminoácidos (19 aminoácidos de peptídeo sinal e 452 aminoácidos referente ao ectodomínio, 53 aminoácidos relacionado ao endodomínio e um códon de parada), como descrito por Tordo et al. (1986b) e Sato et al. (2004). A padronização da metodologia utilizada para o sequenciamento da glicoproteína permitiu a interpretação dos resultados obtidos para o gene G. Os oligonucleotídeos utilizados para sequenciar a região codificadora para a glicoproteína funcionaram dentro do esperado, sendo que apenas um dos primers (primer B) não se mostrou eficiente, provavelmente em virtude da degeneração ou de diferenças entre os genomas da variante mantida por populações de morcegos hematófagos $D$. rotundus e da sequência tomada como base para o desenho dos oligonucleotídeos.

Da mesma maneira que o segmento de 320 nucleotídeos, compreendidos entre as posições 1157 e 1476 do gene codificador para a nucleoproteína, os 1575 nucleotídeos correspondentes ao gene codificador para glicoproteína relacionou as amostras brbvusp01/06 e brdrusp100/07 às amostras relativas ao ciclo aéreo de transmissão (Figuras 25, 26, 41 e 42).

$\mathrm{Na}$ análise comparativa da nucleoproteína e glicoproteína foram identificados os três sítios antigênicos principais: o sítio antigênico I, do aminoácido 374-383 na porção carboxi terminal da nucleoproteína (Figura 22) e os sítios antigênicos II descontínuo dos aminoácidos 34-42 e 198-200 e III contínuo dos aminoácidos 330 ao 338. Nesta região foi possível observar que para as amostras brbvusp01/06 e brdrusp100/07, houve substituição de aminoácido nos sítios antigênicos I na nucleoproteína (Figura 23) e IIa na glicoproteína (Figura 24). Também Sato et al. (2004) observaram que no sítio antigênico IIa da glicoproteína outras amostras brasileiras do ciclo aéreo de transmissão apresentaram mudanças de uma Arginina para uma Lisina.

Por ser externa seria esperado que a glicoproteína fosse a primeira alternativa de escape imunológico do vírus, porém, na análise dos sítios antigênicos IIa, IIb e III, localizados nesta proteína, somente pôde ser observada a substituição de aminoácido no sítio IIa quando 
comparada à amostra PV padrão ou a outras amostras representantes de outros ciclos endêmicos deste vírus. Ito et al. (2001b) confirmaram a sequência de nucleotídeos dos genes N e G das linhagens vacinais RC-HL (AB009663) e Nishigahara (AB044824) que já tinham sido anteriormente descritas, encontrando apenas um nucleotídeo na posição 4688 do genoma de RC-HL de Glicina para Alanina na fita positiva, após várias passagens em BHK-21. Esta substituição de nucleotídeo mudou um aminoácido de Ácido Glutâmico para Lisina no resíduo 439 da glicoproteína.

O peptídeo sinal de 19 aminoácidos descrito por Tordo et al. (1986b) foi identificado e apresentou alta variabilidade, assim como o Domínio Trans-Membrana situado entre os resíduos 440 a 461 (Sato et al., 2004). Na tabela 6 estão as 82 substituições de aminoácidos das amostras brbvusp01/06 e brdrusp100/07 em relação à amostra de referência PV, sendo $67,1 \%$ (55) substituições não conservativas e 54,9\% (45 substituições não conservativas) para as duas amostras brbvusp01/06 e brdrusp100/07 respectivamente.

Sato et al. (2004) observaram os sítios $\mathrm{Ser}_{194}, \mathrm{Arg}_{348}, \mathrm{Glu}_{408}, \mathrm{Cys}_{456}$ e $\mathrm{Asp}_{502}$ conservados em um grupo de amostras relacionadas a morcegos hematófagos durante um estudo realizado com amostras brasileiras. Estes sítios também foram identificados neste estudo e se mostraram próprios apenas para a variante mantida por morcegos hematófagos $D$. rotundus.

Dietzschold et al. (1983) e Seif et al. (1985) descreveram pela primeira vez que uma única substituição de uma Arginina no resíduo 333, localizado no sítio antigênico III, determina o grau de patogenicidade das amostras de vírus da raiva, fato também descrito por Faber et al. (2005). Faber et al. (2007) observaram que a substituição da $\operatorname{Arg}_{333}$ é mais frequentemente observada em sequências da glicoproteína em vírus fixo que entre as sequências da glicoproteína de amostras selvagens. Neste estudo, as análises para o gene codificador da glicoproteína das amostras brbvusp01/06 e brdrusp100/07 demonstraram a presença deste aminoácido no resíduo 333 (Figura 23) confirmando estudos de Sato et al. (2004) e ao contrário dos achados de Sato et al. (2009) que observaram esta substituição em amostras isoladas de morcegos não-hematófagos.

Os domínios GFTCTGVVTEA entre os resíduos 58 a 68, TYTNFVGYVTTTF entre os resíduos 70 a 82, LRKLVPGFGKAYTI entre os resíduos 304 a 317 e VLIPEMQSSLL entre os resíduos 371 a 381 se mostraram conservados para todas as amostras analisadas. A Lys $_{330}$ descrita por Coulon et al. (1998) como responsável pela ligação do vírus ao neurônio e dois dos três sítios de glicosilação nos resíduos 37-39 (Asn-X-Ser sítio 56-58 se considerado o peptídeo sinal) e 319-321 (Asn-X-Thr sítio 338-340 quando consideramos o peptídeo sinal), 
descritos por Anilionis et al. (1981), foram conservados para as amostras brbvusp01/06 e brdrusp100/07, também observado por Mochizuki et al (2011) como conservados para a amostra isolada de um morcego hematófago.

Em um dos sítios de glicosilação, 247-249 (Asn-X-Thr sítio 266-268 se considerado o peptídeo sinal), foram observadas uma substituição não conservativa Asn266Asp e uma substituição conservativa Glu267Asp além de uma substituição conservativa no sítio de lipidação no resíduo 479.

Os alinhamentos da região não codante do pseudogene $\Psi$ confirmaram o que foi observado por Wu et al. (2008) de que esta é uma região muito instável. Tordo et al. (1986a) demonstraram que apesar de não codificar para uma proteína específica, esta região é de extrema importância para a infecção viral, podendo agir na redução da eficiência de transcrição da polimerase viral, o que poderia reduzir a expressão e consequentemente aumentar a patogenicidade (Marston et al., 2007).

Após a finalização do estudo das quatro proteínas N, P, M e G e do Pseudogene Psi ( $\Psi)$ foram inciados os testes para amplificação da polimerase viral. Para o sequenciamento da polimerase (large protein) foram seguidos protocolos já estabelecidos para esta finalidade conforme descrito anteriormente. Os fragmentos amplificados nesta etapa do trabalho variaram entre $1.130 \mathrm{pb}$ e $2.146 \mathrm{pb}$ e a quantidade de DNA necessária estipulada para a reação de sequenciamento variou de $60 \mathrm{ng}$ para o menor fragmento a $125 \mathrm{ng}$ para o maior fragmento, por reação.

Os testes realizados para a purificação do material amplificado para o sequenciamento não mostraram resultados completamente satisfatórios. Novos testes de purificação com os sistemas de colunas selecionados (PureLink ${ }^{\mathrm{TM}}$ PCR Purification Kit e PureLink ${ }^{\mathrm{TM}}$ Quick Gel Extraction Kit Invitrogen ${ }^{\circledR}$ - Invitrogen Corporation, Carlsbad, CA, Estados Unidos), resultaram na obtenção de um material de excelente qualidade, porém não era mantida a concentração mínima de DNA, suficiente para a realização do sequenciamento, mesmo quando a purificação foi realizada com a utilização do sistema de purificação ExoSAP-IT ${ }^{\circledR}$ (GE Healthcare Bio-Sciences Ltd - USB Corporation, Cleveland, OH, Estados Unidos), enzima capaz de selecionar os dímeros formados pelos primers. Para que uma grande quantidade de DNA purificado fosse alcançada, foram então realizadas reações de amplificação em quadruplicata. O material foi concentrado e purificado com os diferentes kits, conforme já descritos, com o objetivo de definir o protocolo mais conveniente. A partir desse material amplificado diversas vezes e posteriormente purificado, os testes de sequenciamento foram retomados. 
As metodologias empregadas para a síntese de cDNA, com a utilização dos sistemas SuperScript $^{\mathrm{TM}}$ Invitrogen $^{\circledR}$ (Invitrogen Corporation, Carlsbad, CA, Estados Unidos) ou High Capacity cDNA Archive Kit ${ }^{\circledR}$ (Applied Biosystems, Foster City, CA, Estados Unidos) usadas anteriormente com a nucleoproteína, com resultados satisfatórios, não foram utilizadas uma vez que era de interesse a amplificação de fragmentos longos como o do gene codificador para a polimerase, com aproximadamente $6,5 \mathrm{~Kb}$. Assim sendo, em uma primeira etapa do estudo da polimerase viral foi padronizada e realizada uma síntese de cDNA diferenciada, com a finalidade de obter um produto amplificado de melhor qualidade.

Como o tamanho do gene é um fator limitante para a amplificação do material genético, nesta etapa do trabalho foram necessários inúmeros testes com fragmentos menores, sendo que para as combinações de iniciadores GliPol1F+GliPol2R (2.056 pb), GliPol3F+GliPol3R (1.133 pb), Pol1F+Pol2R (2.146 pb) e Pol3F+Final (1.699 pb) os resultados foram excelentes, confirmando a eficiência dos oligonucleotídeos desenhados.

Os processos de extração, síntese de cDNA (RT) e de amplificação (PCR) para as amostras brbvusp01/06 e brdrusp100/07 foram realizados concomitantemente para otimização dos resultados, conforme observado em testes anteriores. A realização de uma reação de amplificação para nucleoproteína para confirmar a qualidade do cDNA longo resultou na viabilidade da utilização desta metodologia (Figura 12), uma vez que a síntese de cDNA é uma reação muito mais barata que a clonagem, minimizando os riscos de contaminações que podem ocorrer devido à manipulação de plasmídeos.

Por se tratar de uma proteína multifuncional, a mais importante na replicação e transcrição viral era esperada a observação de poucas mutações nucleotídicas e que esta etapa fosse o passo mais rápido, apesar do tamanho do gene codante da polimerase (mais de 6.000 nucleotídeos). Porém os primeiros testes com a tentativa de amplificação do gene completo não foram promissores, sendo também necessária a amplificação realizada em fragmentos menores, conforme havia sido observado durante o processo de amplificação da proteína G, com a utilização de uma série de combinações de oligonucleotídeos, tendo sido o melhor resultado conseguido com as combinações de primers GliPol1F+GliPol1R (Figura 11), GliPol3F+GliPol3R (Figura 12) e GliPol1F+GliPol2R (Figura 13). Com estas combinações foi possível sequenciar a porção inicial de 798 nucleotídeos (266 aminoácidos - fragmento 1) da proteína L para a amostra estudada brbvusp01/06. Todas as combinações de iniciadores amplificaram fragmentos da polimerase viral sendo sequenciados 76,2\% (4970 nucleotídeos) da amostra estudada brbvusp01/06 e 44,6\% (2910 nucleotídeos) da amostra estudada brdrusp100/07 [porcentagens calculadas em relação aos 6515 nucleotídeos da amostra PV]. 
Como não foi possível a amplificação de todo o gene, uma análise parcial para os fragmentos amplificados da polimerase foi realizada (Figuras 46 a 64) onde foi mais uma vez observada a distinção entre as amostras que segregam dando origem ao cluster que agrupa as amostras relacionadas aos ciclos aéreo e terrestre de transmissão da raiva. A maioria das sequências de polimerase disponíveis no GenBank, inclusive do estudo de Ming et al. (2009) foram estudadas a partir de linhagens vacinais ou de amostras que segregam junto com amostras de variantes genéticas relacionadas ao ciclo terrestre de transmissão (Beckert et al., 2009; Nagaraja et al., 2008). Estudos filogenéticos até então realizados com a polimerase não são capazes de definir a variante genética em virtude do número mínimo de sequências do gene codificador para esta proteína disponíveis no banco de dados, o que torna mais importante ainda o seu estudo, uma vez que Wu et al. (2007) menciona que o gene L pode ser o melhor modelo para análises do tipo "molecular clock" ou similares, considerando seu nível de conservação. Wu et al. (2007) em um estudo demonstrou que as análises genealógicas de cada um dos genes do vírus da raiva apresentaram a mesma topologia da análise já conhecida para genotipagem com a nucleoproteína, este fato também pôde ser observado em nossas análises.

Segundo Poch et al. (1990), a polimerase do vírus da raiva apresenta seis blocos conservados quando comparada a polimerases de outros vírus da ordem Mononegavirales. Os blocos II e III apresentam mais domínios funcionais.

O bloco I compreende a região entre os resíduos 232 e 423 da amostra PV. No bloco I são descritos três resíduos como estritamente ou conservativamente mantidos (Poch et al., 1990), entretanto o domínio NYTLMLKDLFL(S/A)R entre os resíduos 241 e 253 (amostra de referencia PV) apresentou uma única substituição não conservativa no resíduo 252 onde uma Serina presente na amostra PV foi substituida por uma Alanina na amostra brbvusp01/06. Neste estudo o fragmento 1 foi sequenciado até o resíduo 266 para a amostra brbvusp01/06 não compreendendo os domínios GNSGYEVIKILEPYVVNSLVQ (resíduos 291 a 311 - PV) e VYGCYRHWGHPYID (resíduos 364 a 377 - PV). O terceiro domínio apresenta uma região importante GHP, resíduos 373-375, onde a Histidina é conformacionalmente exposta e apresenta papel funcional.

O bloco II compreende a região entre os resíduos 504 e 607 e está envolvido no posicionamento e ligação do RNA molde. O fragmento 2 sequenciado para a amostra brbvusp01/06 iniciou a partir do resíduo 595 não sendo possível observar o bloco II neste estudo. 
No bloco III, resíduos 608 a 831, estão situados os quatro principais motifs (A-D) descritos por Poch et al. (1990) e Schnell e Conzelmann (1995). O motif A (AFHLDYEKWNNHQ) entre os resíduos 614 a 626 se mostrou 100\% conservado entre as amostras brbvusp01/06 e brdrusp100/07 (fragmentos 2 e 2 2a). O motif B (TCWNGQDGGLEGLRQKGWSLVSLLMID) entre os resíduos 686 a 712 abrange um domínio conservado entre os resíduos 693 a 708, foi identificado nas amostras brbvusp01/06 e brdrusp100/07 e no resíduo 706 a amostra brdrusp100/07 apresentou uma substituição não conservativa de uma Valina (amostra PV) para uma Glicina. O motif C (VLAQGDNQVL) entre os resíduos 725 a 734 apresenta o penta peptídeo QGDNQ (727-731) que ao ser suprimido no estudo desenvolvido por Schnell \& Conzelmann (1995) se mostrou essencial para expressão do gene codificador da polimerase viral. A amostra brdrusp100/07 apresentou o penta peptídeo estritamente conservado em relação a amostra PV entretanto apenas para a amostra brbvusp01/06 foram observadas duas substituições não conservativas nos resíduos 728 (Glicina na PV por Ácido Glutâmico) e 729 (Ácido Áspártico na amostra PV por uma Asparagina). O motif D (FRGNILVPESKRW) resíduos 797-809 se mostrou 100\% conservado entre todas as sequencias do dataset analizado.

O bloco IV, resíduos 889 a 1060, rico em Prolina ainda não tem seu papel muito bem descrito, mas possivelmente esteja envolvido na ligação de nucleotídeos (Poch et al., 1990; Marston et al., 2007). O fragmento 3 foi sequenciado para amostra brbvusp01/06 a partir do resíduo 976 sendo possível observar apenas os 84 resíduos finais deste bloco onde o domínio FRGNILVPESKRW (resíduos 1041 a 1053) descrito por Poch et al. (1990) como conservativamente mantido pôde ser observado com apenas uma substituição conservativa no resíduo 1047, uma Isoleucina na amostra PV e uma Valina para a amostra brbvusp01/06.

O bloco V compreendido entre os resíduos 1090 a 1327 apresenta seis domínios previamente descritos por Poch et al. (1990). Os domínios PHPSEML (resíduos 1116 a 1122), GYLGS (resíduos 1164 a 1168) e DFPLEE (resíduos 1224 a 1229) foram 100\% conservados em todas as sequências analizadas. O domínio VKRAL, resíduos 1189 a 1193, foi conservado para as amostras da variante mantida por morcegos hematófagos D. rotundus e os domínios DFMFQ (1283-1287) e FHWHL (1311-1315) não puderam ser observados, pois o fragmento 3 foi sequenciado até o resíduo 1234 para as amostras estudadas (brbvusp01/06 e brdrusp100/07). Segundo Marston et al. (2007) o bloco V apresenta numerosos resíduos invariantes de Cisteína e Histidina fato que foi confirmado nas análises realizadas para os fragmentos sequenciados. O bloco VI é o menos conservado GxGxG (1705-1710) precedido de uma Lisina 19-22 resíduos upstream que exerce o papel de poliadenilação ou atividade 
proteína kinase (Poch et al., 1990) e finalmente uma região amino-terminal (56-61) altamente conservado também foi identificado nas amostras mantidas por D. rotundus e quando comparada à amostra PV foi $100 \%$ conservada. Estes domínios de 4 a 7 resíduos são estritamente ou altamente conservados na maioria das análises.

Das 154 substituições de aminoácidos, $93(60,4 \%)$ foram não conservativas para a amostra brbvusp01/07 e das 102 substituiçoes para a amostra brdrusp100/07, 66 (64,7\%) foram não conservativas.

Na posição 8 (Figura 65a) apenas a amostra brbvusp01/06 (amostra estudada) e EU293113 (cão da Guiana), únicas relacionadas à variante mantida por morcegos hematófagos $D$. rotundus, apresentam uma mudança de Tyr (na amostra referência PVNC_001542) para Phe, assim como em outros treze resíduos com substituições conservativas $\left(\mathrm{Glu}_{139}, \mathrm{Lys}_{217}, \mathrm{Gly}_{683}, \mathrm{Thr}_{1092}, \mathrm{Arg}_{1139}, \mathrm{Ala}_{1255}, \mathrm{Val}_{1617}, \mathrm{Cys}_{1619}, \mathrm{Val}_{1852}, \mathrm{Ala}_{1889}, \mathrm{Ala}_{2057}\right.$, $\mathrm{Ala}_{2058}, \mathrm{Arg}_{2089}$ ) e três com substituições conservativas (Arg ${ }_{645}$ [Figura 65b], Val ${ }_{1214}, \mathrm{Asp}_{1336}$ ) o que pode sugerir uma assinatura genética para esta variante. Já na posição 27 pôde ser observada uma Isoleucina apenas para as amostras pertencentes ao ciclo aéreo e uma Valina para as demais amostras (Figura 65c) e também os resíduos 24, 61, 122, 170, 1144, 1342, 1374, 1487 (Figura 65d), 1556, 1653, 1665 e 2101 foram relacionados ao ciclo aéreo de transmissão. Os resíduos 21, 88 (Figura 65e) e 107 foram comuns para as variantes relacionadas à $D$. rotundus e $T$. brasiliensis.

Foi possível também observar a polimerase viral, para a amostra estudada brbvusp01/06, e comparar alguns resíduos importantes segundo Ming et al. (2009), como a $\mathrm{Cys}_{70}, \mathrm{Val}_{84}, \mathrm{Ala}_{94}, \mathrm{Ile}_{118}, \mathrm{Ser}_{153}$ e Asp $\mathrm{As1}_{191}$. Destes sítios apenas o aminoácido 94 foi diferente entre a amostra brbvusp01/06 e a amostra de referência PV (NC_001542). Nesta posição a amostra estudada apresenta um aminoácido anterior aos descritos por Ming et al. (2009) onde a amostra de referência PV (NC_001542) não possui uma "dupla metionina" (dois consecutivos códons ATG) no sítio de início descrita por este grupo de pesquisadores. A presença da dupla metionina no sítio de início também foi descrita por Mochizuki et al. (2011), que associou à variantes virais mantidas por morcegos americanos, fato não confirmado uma vez que a dupla metionina, além de observada na amostra estudada brbvusp01/06, SHBRV-18 (AY705303) isolada de um morcego L. noctivagans dos Estados Unidos e um guaxinin do Canadá (EU311738), amostras que segregam no ciclo aéreo de transmissão, também pode ser observada em seis cães (FJ712193-5, GU345746, GU345748, GU358653), três ferrets (FJ712196, FJ866835-6), três humano (EF564174, EU643590, GU345747) e duas linhagens vacinais (EU549783, FJ959397) todos isolados na China. 
A combinação dos iniciadores Início+FINAL (11.932pb) e 21g+FINAL (11.877pb), Início+Pol4R (11.643 pb) e 21g+Pol4R (11.588 pb) também foram testadas utilizando a Expand Long Template PCR System ${ }^{\circledR}$ (Roche Diagnostics GmbH, Mannheim, Alemanha) com adaptações das quantidades de enzima, apresentando resultados promissores (Figura 20) para a amplificação com Início+FINAL (11.932 pb) de todo o genoma de uma só vez minimizando a necessidade de clonagem e possibilidade de contaminação por plasmídeos.

De acordo com o objetivo proposto no projeto inicial, foram sequenciados completamente quatro genes codificadores de quatro das cinco proteínas do vírus da raiva, além de parte do gene codificador da polimerase viral da variante relacionada e mantida por populações de morcegos hematófagos $D$. rotundus e comparadas filogeneticamente com a amostra PV e outras variantes previamente descritas.

Apesar das quatro primeiras proteínas virais estarem completamente sequenciadas, a metodologia necessária padronizada e a amplificação do material genômico do gene codificador para a polimerase ter se mostrado extremamente eficiente, o sequenciamento do gene codificador para a polimerase deste vírus não foi facilitado pelo conhecimento adquido durante este estudo como para as demais proteínas. Além disto, poucos trabalhos se dedicaram a um estudo desta importante proteína, indispensável para a replicação de todos os vírus. Os trabalhos que retratam a polimerase viral disponíveis na literatura são antigos (Mellon e Emerson, 1978; Poch et al., 1990) e não especificamente desenvolvidos para o vírus da raiva (Hamaguchi et al., 1983; Horikami et al., 1992).

Apenas muito recentemente alguns grupos têm sequenciado a polimerase ao estudar o vírus da raiva completamente (Delmas et al., 2008; Nagaraja et al., 2008; Beckert et al., 2009; Ming et al., 2009; Mochizuki et al., 2009, 2011), porém sem que relatem especificamente os achados relacionados a esta proteína. Estes grupos não descrevem dificuldades para o estudo da polimerase, como fatores relacionados ao rendimento da reação de PCR e a determinação da concentração ideal de DNA necessário ao sequenciamento, ao contrário do observado durante o desenvolvimento deste estudo.

Os resíduos $\mathrm{Ala}_{377}, \mathrm{Thr}_{379}, \mathrm{Thr}_{433}$ na nucleoproteína, $\mathrm{Asn}_{61}, \mathrm{Ser}_{68}, \mathrm{Gly}_{112}$ na fosfoproteína, $\mathrm{Leu}_{82}, \mathrm{Ile}_{148}, \mathrm{Leu}_{184}$ na proteína de matriz, $\mathrm{Ser}_{213}, \mathrm{Arg}_{367}, \mathrm{Glu}_{427}, \mathrm{Cys}_{475}$, Asp 478 na glicoproteína (Sato et al., 2004) e Phe, $\mathrm{Glu}_{139}$, Lys $217, \operatorname{Arg}_{645}, \mathrm{Gly}_{683}, \mathrm{Thr}_{1092}, \operatorname{Arg}_{1139}$, $\mathrm{Val}_{1214}, \mathrm{Ala}_{1255}, \mathrm{Asp}_{1336}, \mathrm{Val}_{1617}, \mathrm{Cys}_{1619}, \mathrm{Val}_{1852}, \mathrm{Ala}_{1889}, \mathrm{Ala}_{2057}, \mathrm{Ala}_{2058}, \mathrm{Arg}_{2089}$ na polimerase viral podem ser considerados assinaturas genéticas da variante mantida por $D$. rotundus. 
Este trabalho é o primeiro passo para um estudo evolutivo abrangente para o vírus da raiva assim como Delmas et al. (2008) realizou para os Lyssavirus. A polimerase viral ainda necessita de estudos direcionados à conservação, evolução viral e mecanismo de funcionamento. Delmas et al. (2008) questiona a classificação genética com base apenas na identidade de nucleotídeos da proteína N conforme sugerido por Kissi et al. (1995) além da necessidade de novos estudos de polimorfismo em todas as proteínas virais. Davis et al. (2006) ao analisar a dinâmica e a história evolutiva do vírus da raiva descreve que a origem do vírus em morcegos no continente Americano ainda é desconhecida, não excluindo a possibilidade da existência da raiva em morcegos, antes da colonização do Novo Mundo.

Finalmente, o estudo dos morcegos como reservatórios não se restringe ao vírus da raiva, uma vez que Calisher et al. (2006) e Zhengli (2010) relatam a identificação de mais de 80 vírus diferentes em amostras provenientes de morcegos, sugerindo a possibilidade de que os morcegos possam dispor um sistema imune diferenciado ou ainda de alguma atividade antiviral, uma vez que algumas dessas viroses identificadas em morcegos, aparentemente não são letais para estes animais.

Nos últimos cinco anos a raiva na América Latina apresentou uma alteração de perfil epidemiológico, característico de regiões onde a raiva mantida por populações de cães foi controlada, evidenciando a existência de variantes mantidas por animais silvestres, principalmente morcegos. Estes animais são capazes de desempenhar o papel de transmissores ou, algumas vezes, reservatórios deste vírus, tornando as ações de profilaxia e vigilância epidemiológica imprescindíveis para manter o controle da doença e evitar novos surtos de raiva. 


\section{CONCLUSÕES}

O estudo genético da variante do vírus da raiva mantida por populações de morcego $D$. rotundus, isolada de uma amostra deste morcego no Brasil foi desenvolvido durante o período de março de 2007 a novembro de 2010 sendo possível concluir que:

a) Um protocolo rápido e econômico para a obtenção de cDNA para o vírus da raiva independente de clonagem foi estabelecido e testado mostrando-se eficiente;

b) Os primers desenhados foram eficientes para o sequenciamento de quatro proteínas virais completas e parte da polimerase da variante do vírus da raiva estudada;

c) Ao se comparar filogenéticamente as amostras estudadas com a amostra padrão da espécie viral Rabies virus, além de outras da mesma espécie viral disponíveis no GenBank, foi possível observar e corroborar a presença dos ciclos aéreo e terrestre de transmissão, previamente descritos e validados para a nucleoproteína, em cada uma das proteínas e fragmentos estudados;

d) A análise da sequência de aminoácidos de cada uma das proteínas virais indicou presença de 31 resíduos que possivelmente representem assinaturas genéticas para a variante mantida por morcegos hematófagos D. rotundus. Esta análise das substituições não conservativas de aminoácidos nas amostras estudadas brbvusp01/06 e brdrusp100/07 demonstrou que a variabilidade genética segue a ordem decrescente de $\mathrm{P}>\mathrm{G}>\mathrm{L}>\mathrm{M}>\mathrm{N}$. 


\section{REFERÊNCIAS*}

Almeida MF, Martorelli LF, Aires CC, Sallum PC, Massad E. Indirect oral immunization of captive vampires, Desmodus rotundus. Virus Res. 2005 Jul;111(1):77-82.

Almeida MF, Martorelli LF, Aires CC, Sallum PC, Durigon EL, Massad E. Experimental rabies infection in haematophagous bats Desmodus rotundus. Epidemiol Infect. 2005 Jun;133(3):523-7.

Anilionis A, Wunner WH, Curtis PJ. Structure of the glycoprotein gene in rabies virus. Nature. 1981;Nov;294(5838):275-8.

Arai YT, Kuzmin IV, Kameoka Y, Botvinkin AD. New lyssavirus genotype from the Lesser Mouse-eared Bat (Myotis blythi), Kyrghyzstan. Emerg Infect Dis. 2003;9(3):333-7.

Arellano-Sota C. Biology, Ecology, and Control of the Vampire Bat. Reviews of Infectious Diseases. 1988;10(4):S615-S619.

Baer GM. The Natural History of Rabies. $2^{\text {nd }}$ ed. Florida: Boca Raton: CRC Press; 1991. 389 p.

Badrane H, Tordo N. Host switching in Lyssavirus history from the Chiroptera to the Carnivora orders. J Virol. 2001;75(17):8096-104.

Banerjee AK. Transcription and replication of rhabdoviruses. Microbiol. Rev. 1987 Mar; 51(1):66-87.

Beckert A, Geue L, Vos A, Neubert A, Freuling C, Müller T. Genetic stability (in vivo) of the attenuated oral rabies virus vaccine SAD B19. Microbiol Immunol. 2009 Jan;53(1):16-21.

Belotto AJ. Organization of Mass Vaccination for Dog Rabies in Brazil. Rev Infect Dis. 1988 Nov-Dec;10(4):S693-6. Available from: http://www.jstor.org/stable/4454720 [2011 Feb 20].

Belotto A, Leanes LF, Schneider MC, Tamayo H, Correa E. Overview of rabies in the Americas. Virus Res. 2005;111:5-12.

\footnotetext{
* De acordo com International Committee of Medical Journal Editors. Uniform requirements for manuscripts submitted to Biomedical Journal: sample references. Available from: http://icmje.org [2007 May 22].
} 
Benmansour A, Leblois H, Coulon P, Tuffereau C, Gaudin Y, Flamand A, Lafay F. Antigenicity of rabies virus glycoprotein. J Virol. 1991;65:4198-203.

Birney EC, Rising JD. Notes on distribuition and reproduction of some bats from Kansas, with remarks on incidence of rabies. Trans Kans Acad Sci. 1967;80:519-24.

Boulger LR, Porterfield JS. Isolation of a virus from Nigerian fruit bats. Trans R Soc Trop Med Hyg. 1958 Sep;52(5):421-4.

Bourhy H, Kissi B, Tordo N. Molecular diversity of the Lyssavirus Genus. Virology. 1993;194:70-81.

Bourhy H, Kissi B, Lafon M, Sacramento D, Tordo N. Antigenic and molecular characterization of bat rabies virus in Europe. J Clin. Microbiol. 1992 Sep;30(9):2419-26.

Botvinkin AD, Poleschuk EM, Kuzmin IV, Borisova TI, Gazaryan SV, Yager P, Rupprecht CE. Novel lyssaviruses isolated from bats in Russia. Emerg Infect Dis. 2003;9(12):1623-5.

Brasil. Departamento de Vigilância Epidemiológica. Protocolo para tratamento de raiva humana no Brasil. Epidemiol Serv Saude. 2009 Out-Dez;18(4):385-94. doi: 10.5123/S167949742009000400008.

Brasil. Ministério da Saúde. Fundação Nacional da Saúde: Coordenação de Doenças transmitidas por vetores e antropozoonozes. Informes técnicos. Brasília, 2005. Disponível em: http://portal.saude.gov.br/portal/arquivos/pdf/nota_raiva.pdf\#search=\%22\%22Portel $\% 22 \% 20$ \%2B\%20raiva\%22. [18 ago. 2006].

Brasil. Ministério da Saúde. Secretaria de Vigilância em Saúde. Guia de Vigilância Epidemiológica. Série A. 6. ed. Normas e Manuais Técnicos. Brasília: Ministério da Saúde; 2005. 816 p.

Brasil. Ministério da Saúde. Fundação Nacional da Saúde. Morcegos em áreas urbanas e rurais: Manual de Manejo e Controle. 2. ed. Brasília: Ministério da Saúde; 1998. 117 p.

Brown LJ, Rosatte RC, Fehlner-Gardiner C, Knowles MK, Bachamnn P, Davies JC, Wandeler A, Sobey K, Donovan D. Immunogenicity and efficacy of two vaccines in wild-caught, captive raccoons. J Wild Dis. 2011 Jan;47(1):182-94. 
Burnett CD. Bat rabies in Illinois: 1965 to 1986. J Wild Dis. 1989;25(1):10-9.

Calisher CH, Childs JE, Field HE, Holmes KV, Schountz T. Bats: important reservoir hosts of emerging viruses. Clin Microbiol Rev. 2006 Jul:19(3):531-45. doi: 10.1128/CMR.00017-06.

Carini A. Sur une grande epizootie de rage. Ann Inst Pasteur. 1911;25:843-6.

Carnieli Jr P, Castilho JG, Fahl Wde O, Véras NM, Timenetsky Mdo C. Genetic characterization of Rabies virus isolated from cattle between 1997 and 2002 in an epizootic area in the state of São Paulo, Brazil. Virus Res. 2009a Sep;144(1-2):215-24.

Carnieli Jr P, Castilho JG, Fahl Wde O, Véras NM, Carrieri ML, Kotait I. Molecular characterization of Rabies Virus isolates from dogs and crab-eating foxes in Northeastern Brazil. Virus Res. 2009b Apr;141(1):81-9.

Carnieli Jr P, Fahl Wde O, Castilho JG, Oliveira Rde N, Macedo CI, Durymanova E, Jorge RS, Morato RG, Spíndola RO, Machado LM, Ungar de Sá JE, Carrieri ML, Kotait I. Characterization of Rabies virus isolated from canids and identification of the main wild canid host in Northeastern Brazil. Virus Res. 2008 Jan;131(1):33-46.

Carnieli Jr P, Brandão PE, Carrieri ML, Castilho JG, Macedo CI, Machado LM, Rangel N, de Carvalho RC, de Carvalho VA, Montebello L, Wada M, Kotait I. Molecular epidemiology of rabies virus strains isolated from wild canids in Northeastern Brazil. Virus Res. 2006 Sep;120(1-2):113-20.

Carrieri ML, Favoretto SRL, Carnieli P, Queiroz LH, Souza MCAM, Panachao MRI, Takaoka NY, Harmani NMS, Kotait I. Desmodus rotundus como transmissor da raiva canina e felina no Estado de São Paulo, 1998-2000. In: Seminário Internacional Morcegos como Transmissores da Raiva; 22-24 de agosto 2000; São Paulo; 2000. p. 42-3.

Castilho JG, Canello FM, Scheffer KC, Achkar SM, Carrieri ML, Kotait I. Antigenic and genetic characterization of the first rabies virus isolated from the bat Eumops perotis in Brazil. Revista do Instituto de Medicina Tropical de São Paulo. 2008;50:95-9.

Cisterna D, Bonaventura R, Caillou S, Pozo O, Andreau ML, Fontana LD, Echegoyen C, de Mattos C, de Mattos C, Russo S, Novaro L, Elberger D, Freire MC. Antigenic and molecular characterization of rabies virus in Argentina. Virus Res. 2005;109(2):139-47.

Constantine DG. Rabies transmission by non-bite route. Public Health Rep. 1962;77:287-9. 
Costa WA, Cunha RS, Bolzan VL, Silva AdeC, Caporale GM, Chaves LB, Oselka GW, Junqueira DA, Panacho MR, Dias RA, Takaoka NY. Immunogenicity and safety of a new Vero cell rabies vaccine produced using serum-free medium. Vaccine. 2007 Nov;25(48):81405 .

Coulon P, Ternaux JP, Flamand A, Tuffereau C. An avirulent mutant of rabies virus is unable to infect motoneurons in vivo and in vitro. J Virol. 1998 Jan;72(1):273-8.

Cox JH, Dietzschold B, Schneider LG. Rabies virus glycoprotein. II. Biological and serological characterization. Infect Immun. 1977 Jun;16(3):754-9.

da Rosa EST, Kotait I, Barbosa TFS, Carrieri ML, Brandão PE, Pinheiro AS, Begot AL, Wada MY, De Oliveira RC, Grisard EC, Ferreira M, Lima RJS, Montebello L, Medeiros DBA, Sousa RCM, Bensabath G, Carmo EH, Vasconcelos PFC. Bat-transmitted Human Rabies Outbreaks, Brazilian Amazon. Emerg Infect Dis. 2006 Aug;12(8):1197-202.

Davis PL, Bourhy H, Holmes EC. The evolutionary history and dynamics of bat rabies virus. Infect Genet Evol. 2006 Nov;6(6):464-73. doi: 10.1016/j.meegid.2006.02.007.

Dean DJ, Abelseth MK, Atanasiu P. The Fluorescent Antibody. In: Meslin F-X, Kaplan MM, Koprowski H. Laboratory techniques in rabies. $4^{\text {th }}$ ed. Genebra: World Health Organization; 1996. p. 88-95.

Delmas O, Holmes EC, Talbi C, Larrous F, Dacheux L, Bouchier C, Bourhy H. Genomic Diversity and Evolution of the Lyssaviruses. Plos ONE. 2008;3(4):e2057. doi: 10.1371/journal.pone.0002057

Delpietro HA, Gury-Dhomen F, Largui OP, Mena-Segura C, Abramo L. Monoclonal Antibody Characterization of Rabies Virus Strains Isolated in the River Plate Basin. J Vet Med B. $1997 ; 44: 477-83$.

Diaz AM, Papo S, Rodrigues A, Smith JS. Antigenic analysis of rabies-virus isolates from Latin America and the Caribbean. Journal of Veterinary Medicine B. 1994;41:153-60.

Dietzschold B, Wunner WH, Wiktor TJ, Lopes AD, Lafon M, Smith CL, Koprowski. Characterization of an antigenic determinant of the glycoprotein that correlates with the pathogenicity of rabies virus. Proc Natl Acad Sci USA. 1983;80:70-4. doi: 10/1073/pnas.80.1.70. 
Dietzschold B, Rupprecht CE, Tollis M, Lafon M, Mattei J, Wiktor TJ, Koprowski. Antigenic Diversity of the Glycoprotein and Nucleocapsid Proteins of Rabies and Rabies-Related Viruses: Implications for Epidemiology and Control of Rabies. Rev Infect Dis. 1988 NovDez;10(Supp14):S785-98.

dos Santos AS, Lemos MA, Pereira CA, Jorge SA. Rabies virus glycoprotein expression in Drosophila S2 cells: influence of re-selection on protein expression. Biotechnol J. 2009 Nov;4(11):1578-81.

Faber M, Faber ML, Li J, Preuss MA, Schnell MJ, Dietzschold B. Dominance of a nonpathogenic glycoprotein gene over a pathogenic glycoprotein gene in rabies virus. J Virol. $2007 \mathrm{Jul} ; 81(13): 7041-7$.

Faber M, Faber ML, Papaneri A, Bette M, Weihe E, Dietzschold B, Schnell MJ.A single amino acid change in rabies virus glycoprotein increases virus spread and enhances virus pathogenicity. J Virol. 2005 Nov;79(22):14141-8.

Faber M, Pulmanausahakul R, Nagao K, Prosniak M, Rice AB, Koprowski H, Schnell MJ, Dietzschold B. Identification of viral genomic elements responsible for rabies virus neuroinvasiveness. Proc Natl Acad Sci USA. 2004;101:16328-32.

Familusi JB, Osunkoya BO, Moore DL, Kemp GE, Fabiyi A. A fatal human infection with Mokola virus. Am J Trop Med Hyg. 1972 Nov;21(6):959-63.

Fauquet CM, Mayo MA, Maniloff J, Desselberger U, Ball LA. Virus Taxonomy: The eighth report of the International Committee on Taxonomy of Viruses. Academic Press. San DiegoCalifórnia (USA); 2004. 1162 p.

Favi M, Nina A, Yung V, Fernandez J. Characterization of rabies virus isolates in Bolivia. Virus Res. 2003 Nov;97(2):135-40.

Favi M, De Mattos CA, Yung V, Chala E, López LR, De Mattos CC. First case of human rabies in Chile caused by an insectivorous bat virus variant. Emerg Infect Dis. 2002 Jan;8(1):79-82.

Favoretto SR, De Mattos CC, Morais NB, Araújo FAA, De Mattos CA. Rabies in Marmosets (Callithrix jacchus) from the State of Ceará, Brazil. Emerg Infect Dis. 2001;7(6):1062-5. 
Favoretto SR, Carrieri ML, Cunha EM, Aguiar EA, Silva LH, Sodre MM, Souza MC, Kotait I. Antigenic typing of Brazilian rabies virus samples isolated from animals and humans, 19892000. Rev Inst Med Trop São Paulo. 2002;44(2):91-5.

Favoretto SR. Antigenic and genetic typification of rabies virus as tool for epidemiological surveillance. Rabies virus detection and phylogenetic studies from human exhumed sample. In: XIV RITA - Rabies in the Americas; 2003; Philadelphia-PA, USA; 2003. p. 8.

Flores-Crespo R. Biologia de murcielagos hematófagos. In: Seminário Internacional Morcegos como Transmissores da Raiva; 22-24 de agosto 2000; São Paulo; 2000. p. 46.

Fraser J, Fang S, Barfoot R, Clayton PT. Idiopathic rhabdomyolysis. J R Soc Med. 1996 Dec;89(12):706-7.

Frazatti-Galina NM, Mourão-Fuches RM, Paoli RL, Silva MLN, Miyaki C, Valentini EJG, Raw I, Higashi HG. Vero-cell rabies vaccine produced using serum-free medium. Vaccine. 2004;23:511-7.

Fuenzalida E, Palácios R. Un método mejorado para la preparacion de la vacuna antirrabica. Boll Inst Bacteriol. 1955;8:3.

Gaudin Y, Tuffereau C, Segretain D, Knossow M, Flamand A. Reversible conformational changes and fusion activity of rabies virus glycoprotein. J Virol. 1991 Sep;65(9):4853-9.

Gaudin Y, Ruigrok RW, Knossow M, Flamand A. Low-pH conformational changes of rabies virus glycoprotein and their role in membrane fusion. J Virol. 1993 Mar;67(3):1365-72.

Goldwasser RA, Kissling RE. Fluorescente antibody staining of street and fixed rabies virus antigens. Proceedings Society for Expermental Biology and Medicine. 1958;98:219-23.

Gould AR, Hyatt AD, Lunt R, Kattenbelt JA, Hengstberger S, Blacksell SD. Characterisation of a novel lyssavirus isolated from Pteropid bats in Australia. Virus Res. 1998 Apr;54(2):16587.

Gong W, Jiang Y, Za Y, Zeng Z, Shao M, Fan J, Sun Y, Xiong Z, Yu X, Tu C. Temporal and spatial dynamics of rabies viruses in China and Southeast Asia. Virus Res. 2010 Jun;150(12):111-8. 
Hamaguchi M, Yoshida T, Nishikawa K, Naruse H, Nagai Y. Transcriptive complex of Newcastle disease virus. Both $\mathrm{L}$ and $\mathrm{P}$ proteins are required to constitute an active complex. Virology. 1983;128:105-17.

Harty RN, Paragas J, Sudol M, Palese P. A proline-rich motif within the matrix protein of vesicular stomatitis virus and rabies virus interacts with WW domains of cellular proteins: implications for viral budding. J Virol. 1999 Apr;73(4):2921-9.

Harty RN, Brown ME, McGettigan JP, Wang G, Jayakar HR, Huibregtse JM, Whitt MA, Schnell MJ. Rhabdoviruses and the cellular ubiquitin-proteasome system: a budding interaction. J Virol. 2001 Nov;75(22):10623-9.

Hirano S, Itou T, Shibuya H, Kashiwazaki Y, Sakai T. Molecular epidemiology of rabies virus isolates in Uganda. Virus Res. 2010 Jan;147(1):135-8.

Horack HM. Allergy as a factor in the development of reactions to antirabic treatment. Ammer J Med Sci. 1939;197:672-82.

Horikami SM, Curran J, Kolakofsky D, Moyer SA. Complexes of Sendai virus NP-P and P-L proteins are required for defective interfering particle genome replication in vitro. J Virol. 1992;66:4901-8.

Hummeler K, Koprowski H, Wiktor TJ. Structure and Development of Rabies Virus in Tissue Culture. J Virol. 1967 Feb;1(1):152-70.

Hurst EW, Pawan JL. An outbreak of rabies in Trinidad, without history of bites and with symptoms of acute ascending myelitis. Lancet. 1931;2:622-8.

Hurst EW, Pawan JL. A further account of the Trinidad outbreak of acute rabic myelitis. J. Pathol. Bacteriol. 1932;35:301-21.

International Committee on Taxonomy of Viruses - ICTV. Available from: http://www.ictvonline.org/virusTaxonomy.asp?version=2009. [2009 Dec 17].

Ito M, Arai YT, Itou T, Sakai T, Ito FH, Takasaki T, Kurane I. Genetic characterization and geographic distribution of rabies virus isolates in Brazil: identification of two reservoir, dogs and vampire bats. Virology. 2001a;284:214-22. 
Ito N, Kakemizu M, Ito KA, Yamamoto A, Yoshida Y, Sugiyama M, Minamoto N. A comparison of complete genome sequences of the attenuated RC-HL strain of rabies virus used for production of animal vaccine in Japan, and the parenteral Nishigahara strain. Microbiol. Immunol. 2001b;45(1):51-8.

Jackson AC, Wunner WH. Rabies. London: Academic Press - Elservier; 2007. 800 p.

Johnson N, Un H, Fooks AR, Freuling C, Müller T, Aylan O, Vos A. Rabies epidemiology and control in Turkey: past and present. Epidemiol Infect. 2010 Mar;138(3):305-12.

Kemp GE, Causey OR, Moore DL, Odelola A, Fabiyi A. Mokola virus. Further studies on IbAn 27377, a new rabies-related etiologic agent of zoonosis in Nigeria. Am J Trop Med Hyg. 1972 May;21(3):356-9.

King AA, Meredith CD, Thomson GR. The biology of southern African lyssavirus variants. Curr Top Microbiol Immunol. 1994;187:267-95.

King AA, Turner GS. Rabies: a review. J Comp Pathol. 1993 Jan:108(1):1-39.

Kissi B, Tordo N, Bourhy H. Genetic polymorphism in the rabies virus nucleoprotein gene. Virology. 1995;209(2):526-37.

Kissling RE. Growth of rabies virus in non-nervous tissue culture. Proc Soc Exp Biol Med. 1958;98(2):223-5.

Kobayashi Y, Sato G, Shoji Y, Sato T, Itou T, Cunha EM, Samara SI, Carvalho AA, Nociti DP, Ito FH, Sakai T. Molecular epidemiological analysis of bat rabies viruses in Brazil. J Vet Med Sci. 2005;67(7):647-52.

Kobayashi Y, Okuda H, Nakamura K, Sato G, Itou T, Carvalho AA, Silva MV, Mota CS, Ito FH, Sakai T. Genetic analysis of phosphoprotein and matrix protein of rabies viruses isolated in Brazil. J Vet Med Sci. 2007 Nov;69(11):1145-54.

Koprowski H, Cox HR. Studies on chick-embryo-adapted rabies virus; culture characteristics and pathogenicity. J Immunol. 1948;60:533-44.

Kuzmin IV, Hughes GJ, Botvinkin AD, Orciai LA, Rupprecht CE. Phylogenetic relationships of Irkut an West Caucasian bat viruses within the Lyssavirus genus and suggested quantitative 
criteria based on the $\mathrm{N}$ gene sequence for lyssavirus genotype definition. Virus Res. 2005 Jul;111(1):28-43.

Kuzmin IV, Orciari LA, Arai YT, Smith JS, Hanlon CA, Kameoka Y, Rupprecht CE. Bat lyssaviruses (Aravan and Khujand) from Central Asia: phylogenetic relationships according to N, P and G gene sequences. Virus Res. 2003;97:65-79.

Lafon M, Herzog M, Sureau P. Human rabies vaccines induce neutralising antibodies against the European bat rabies virus (Duvenhage). Lancet. 1986 Aug;30:2(8505):515.

Lentz TL, Burrage TG, Smith AL, Crick J, Tignor GH. Is the acetylcholine receptor a rabies virus receptor? Science. 1982 Jan;8;215(4529):182-4.

Lopez RA, Miranda PP, Tejada VE, Fishbein DB. Outbreak of human rabies in the Peruvian jungle. Lancet. 1992 Feb;339(8790):408-12.

Lopes RL, Anaya E, Arenas A, Fernandez M. Tipificacion antigênica del vírus rabico em el Peru. In: IX International meeting on research advances and rabies control in the Americas. Puerto Vallarta, Jalisco, México, December 8-12, 1998. p 40-1.

Loza-Rubio E, Aguilar-Setien A, Bahloul C, Brochier B, Pastoret PP, Tordo N. Discrimination between epidemiological cycles of rabies in Mexico. Arch Med Res. 1999;30(2):144-9.

Lord RD. Seasonal Reproduction of Vampire Bats and Its Relation to Seasonality of Bovines Rabies. Journal of Wildlife Disease. 1992;28(2):292-4.

Maddison DR, Maddison WP. MacClade 4: Analysis of Phylogeny and Character Evolution, version 4.0. Sunderland: Sinauer Associates; 2000.

Markotter W, Van Eeden C, Kuzmin IV, Rupprecht CE, Paweska JT, Swanepoel R, Fooks AR, Sabeta CT, Cliquet F, Nel LH. Epidemiology and pathogenicity of African bat lyssaviruses. Dev Biol (Basel). 2008;131:317-25.

Martorelli LFA, Aguiar EAC, Almeida MF, Durigon EL. Genetic characterization of rabies virus isolates from Sao Paulo State, Brazil, during the period 1989-2000. In: XII International Meeting on Research Advances and Rabies Control in the Americas; November, 12-16 2001, Peterborough, Canada. Peterborough, Canada; 2001. p. 62. 
Mattos CA, De Mattos CC, Smith JS, Miller ET, Sara-Papo AV, Osburn BI. Genetic characterization of rabies field from Venezuela. J Clin Microbiol. 1996;34(6):1553-8.

Mattos CC, De Mattos CA, Loza-Rubio E, Aguilar-Setién A, Orciari LA, Smith JS. Molecular Characterization of Rabies Virus Isolates from Mexico: Implications for Transmission Dynamics and Human Risk. Am J Trop Med Hyg. 1999;61:587-97.

Mattos CA, Favi M, Yung V, Pavletic C, De Mattos CC. Bat rabies in urban centers in Chile. Journal of Wildlife Diseases. 2000;36(2):231-40.

McElhinney LM, Marston DA, Stankov S, Tu C, Black C, Johnson N, Jiang Y, Tordo N, Müller T, Fooks AR. Molecular epidemiology of lyssaviruses in Eurasia. Dev Biol (Basel). 2008;131:125-31. Review.

Mellon MG, Emerson SU. Rebinding of transcriptase components (L and NS proteins) to the nucleocapsid template of vesicular stomatitis virus. J Virol. 1978;Sep;27(3):560-7.

Meredith CD, Prossouw AP, Koch HP. An unusual case of human rabies thought to be of chiropteran origin. S Afr Med J. 1971 Jul;17;45(28):767-9.

Ming P, Du J, Tang Q, Yan J, Nadin-Davis SA, Li H, Tao X, Huang Y, Hu R, Liang G. Molecular characterization of the complete genome of a street rabies virus isolated in China. Virus Res. 2009 Jul;143(1):6-14.

Mita T, Shimizu K, Ito N, Yamada K, Ito Y, Sugiyama M, Minamoto N. Amino acid at position 95 of the matrix protein is a cytopathic determinant of rabies virus. Virus Res. 2008 Oct;137(1):33-9.

Mochizuki N, Kobayashi Y, Sato G, Itou T, Gomes AA, Ito FH, Sakai T. Complete genome analysis of a rabies virus isolate from Brazilian wild fox. Arch Virol. 2009;154(9):1465-88. doi: 10.1007/s00705-009-0475-9

Mochizuki N, Kobayashi Y, Sato G, Hirano S, Itou T, Ito FH, Sakai T. Determination and molecular analysis of the complete genome sequence of two wild-type rabies viruses isolated from a haematophagous bat and a frugivorous bat in Brazil. J Vet Med Sci. 2011; Feb 2 [Epub ahead of print].

Moreno JA, Baer GM. Experimental rabies in the vampire bat. Am J Trop Med Hyg. 1980;29(2):254-9. 
Nadin-Davis SA, Casey GA, Wandeler AI. A molecular epidemiological study of rabies virus in central Ontario and western Quebec. J Gen Virol. 1994 Oct;75(Pt 10):2575-83.

Nadin-Davis SA, Casey GA, Wandeler AI. Identification of regional variants of the rabies virus within the Canadian province of Ontario. J Gen Virol. 1993 May;74(Pt 5):829-37

Nadin-Davis SA, Huang W, Wandeler AI. Polymorphism of rabies viruses within the phosphoprotein and matrix protein genes. Arch Virol. 1997;142(5):979-92.

Nadin-Davis SA, Abdel-Malik M, Armstrong J, Wandeler AI. Lyssavirus P gene characterisation provides insights into the phylogeny of the genus and identifies structural similarities and diversity within the encoded phosphoprotein. Virology. 2002 Jul;5;298(2):286-305.

Nagaraja T, Madhusudana S, Desai A. Molecular characterization of the full-length genome of a rabies virus isolate from India. Virus Genes. 2008 Jun;36(3):449-59.

Nowak RM. Walker's mammals of the world. $7^{\text {rd }}$ ed. Baltimore and London, Johns Hopkins University Press, 2 vols. 397pg, 2003.

Organização Panamericana de Saúde (OPAS) - Instituto Panamericano de Proteccion de Alimentos y Zoonosis (INPPAZ) Boletin Vigilância epidemiologica. 1999; vol. XXXI. p 27 e 34.

Pan American Health Organization (PAHO). Los anticuerpos monoclonales em la caracterizacion y vigilancia de los vírus de La rabia em America Latina y el Caribe. Pan Am J Public Health. 2000;8(3):214-7.

Pasteur, L. Méthode pour prevenir la rage apres morsure. Comptes R Acad Sci. 1885; 101:765-72.

Pasteur L, Chamberland C, Roux E, Thuiller L. Nouveaux faits pour servir à la conaissance de la rage. Comptes R Acad Sci. 1882;95:1187-92.

Pasteur L, Chamberland C, Roux E, Thuiller L. Sur la Rage. Comptes R Acad Sci. 1881;92:1259-60.

Pawan JL. Rabies in the vampire bat of Trinidad with special reference to the clinical course and the latency of infection. Ann Trop Med Parasitol. 1936;30:401-22. 
Pawan JL. Rabies in the vampire bat of Trinidad, with special reference to the clinical course and the latency of infection. Caribb Med J. 1959;21:137-56.

Perrin P, Portonoï D, Sureau P. Étude de l'adsorption et de la pénétration du vírus rabique: interactions avec lês cellules BHK-21 et lês membranes artificielles. Ann Virol (Inst Pasteur). 1982;v. $133^{\mathrm{E}}$, p. 403-22.

Queiroz-Lima E. A transmissão da raiva dos herbívoros pelos morcegos hematófagos da família Desmodontidae. Ver Depto Nac Prod Anim. 1934;1:165.

Richardson JH, Ramsey RL, Starr LE. Bat rabies in Georgia, 1956-1965. Public Health Reports. 1966;81:1031-5.

Rodrigues YJL, Tamayo JG. Pathogeny of the Experimental Infection with the Rabies Virus in Hematophagous Bat (Desmodus rotundus). Rev Fac Cs Vets. 2000;41(1-3):71-2.

Rousseau CM, Birditt BA, McKay AR, Stoddard JN, Lee TC, McLaughlin S, Moore SW, Shindo N, Learn GH, Korber BT, Brander C, Goulder PJ, Kiepiela P, Walker BD, Mullins JI. Large-scale amplification, cloning and sequencing of near full-length HIV-1 subtype C genomes. J Virol Methods. 2006 Sep;136(1-2):118-25.

Sacramento D, Bourhy H, Tordo N. PCR technique as an alternative method for diagnosis and molecular epidemiology of rabies virus. Mol Cel Probes. 1991;6:229-40.

Sato G, Kobayashi Y, Motizuki N, Hirano S, Itou T, Cunha EM, Ito FH, Sakai T. A unique substitution at position 333 on the glycoprotein of rabies virus street strains isolated from nonhematophagous bats in Brazil. Virus Genes. 2009 Feb;38(1):74-9.

Sato G, Itou T, Shoji Y, Miura Y, Mikami T, Ito M, Kurane I, Samara SI, Carvalho AAB, Nociti DP, Ito FH, Sakai T. Genetic and phylogenetic analysis of glycoprotein of rabies virus isolated from several species in Brazil. J Vet Med Sci. 2004 Jul;66(7):747-53.

Schneider LG, Barnard BJH, Schneider HR Application of monoclonal antibodies for epidemiological investigations and oral vaccination studies: I. African virus. In: Kuwert E, Merieux C, Koprowski H, Bogel K, editors. Rabies in the tropics. Berlin: Springer-Verlag; 1985. p. 47-59. 
Schneider MC, Santos-Burgoa C. Tratamiento contra la rabia humana: un poco de su historia. Revista de Saúde Pública. 1994;28(6):454-63.

Schneider LG, Cox JH. Bat lyssaviruses in Europe. Curr Top Microbiol Immunol. 1994;187:207-18. Review.

Schneider MC, Belotto A, Adé MP. Situación epidemiológica de la rabia humana en América Latina en 2004. Boletín Epidemiológico/OPS. 2005 Mar;26(1):1-4.

Schowelter DB. Characteristics of bat rabies in Alberta. Canadian J Comparative Medicine. 1980;44:70-6.

Seif I, Coulon P, Rollin PE, Flamand A. Rabies virulence: effect on pathogenicity and sequence characterization of rabies virus mutations affecting antigenic site III of the glycoprotein. J Virol. 1985;53:926-34.

Selimov MA, Tatarov AG, Botvinkin AD, Klueva EV, Kulikova LG, Khismatullina NA. Rabies-related Yuli virus; identification with a panel of monoclonal antibodies. Acta Virol. 1989 Dec;33(6):542-6.

Selimov MA, Smekhov AM, Antonova LA, Shablovskaya EA, King AA, Kulikova LG. New strains of rabies-related viruses isolated from bats in the Ukraine. Acta Virol. 1991 May;35(3):226-31.

Sellers TF. Complications of antirabic treatment. J Med Am Ga. 1947;36:30-5.

Setien AA, Brochier B, Tordo N, De Paz O, Desmettre P, Péharpre D, Pastoret P-P. Experimental rabies infection and oral vaccination in vampire bats (Desmodus rotundus). Vaccine. 1998;16(11-12):1122-6.

Shimizu K, Ito N, Mita T, Yamada K, Hosokawa-Muto J, Sugiyama M, Minamoto N. Involvement of nucleoprotein, phosphoprotein, and matrix protein genes of rabies virus in virulence for adult mice. Virus Res. 2007 Feb;123(2):154-60.

Shope RE, Murphy FA, Harrison AK, Causey OR, Kemp GE, Simpson DIH, Moore DL. Two African Viruses Serologically and Morphologically Related to Rabies Virus. J Virol. 1970 Nov;6(5):690-2.

Silva RA, Rivello GV, Nilsson MR. Isolamento do virus rábico de morcego não hematófago 
da espécie Phyllostomus hastatus hastatus (Pallas). Arquivos do Instituto de Biologia Animal, Rio de Janeiro. 1961;4:115-20.

Singer A, Kauhala K, Holmala K, Smith GC. Rabies in northeastern Europe-the threat from invasive raccoon dogs. J Wild Dis. 2009 Oct;45(4):1121-37.

Slate D, Algeo TP, Nelson KM, Chipman RB, Donovan D, Banton JD, Niezgoda M, Rupprecht. Oral rabies vaccination in North America: opportunities, complexities, and challenges. Plos Negl Trop Dis. 2009 Dec;22;3(12):e549.

Smith JS, Orciari LA, Yager PA, Seidel HD, Warner CK. Epidemiologic and historical relationships among 87 rabies virus isolates as determined by limited sequence analysis. J Infect Dis. 1992;166(2):296-307.

Soares RM, Bernardi F, Sakamoto SM, Heinemann MB, Cortez A, Alves LM, Meyer AD, Ito FH, Richtzenhain LJ. A heminested polymerase chain reaction for the detection of Brazilian rabies isolates from vampire bats and herbivores. Mem Inst Oswaldo Cruz. 2002 Jan;97(1):109-11.

Sodré MM, Gama AR, Almeida MF. Updated listo f bat species positive for rabies in Brazil. Rev Inst Med Trop Sao Paulo. 2010 Mar-Apr;52(2):75-81. doi: 10.1590/S003646652010000200004.

Sokol F, Schlumberger HD, Wiktor TJ, Koprowski H. Biochemical and biophysical studies on the nucleocapsid and on the RNA of rabies virus. Virology. 1969 Aug;38(4):651-65.

Srinivasan A, Burton EC, Kuehnert MJ, Rupprecht C, Sutker WL, Ksiazek TG, Paddock CD, Guarner J, Shieh WJ, Goldsmith C, Hanlon CA, Zoretic J, Fischbach B, Niezgoda M, El-Feky WH, Orciari L, Sanchez EQ, Likos A, Klintmalm GB, Cardo D, LeDuc J, Chamberland ME, Jernigan DB, Zaki SR; Rabies in Transplant Recipients Investigation Team. Transmission of rabies virus from an organ donor to four transplant recipients. $N$ Engl $J$ Med. 2005;352(11):1103-11.

Steece RS, Erickson TJ, Siem RA. Chiropteran rabies in Minnesota: 1976-1980. J Wild Dis. 1982;18:487-9.

Steele JH, Fernandez PJ. History of rabies and global aspects. In: Baer GM. The natural history of rabies. $2^{\text {nd }}$ ed. Florida: Boca Raton: CRC Press; 1991. 
Sulkin SE, Krutzsch PH, Allen R, Wallis C. Studies on the pathogenesis of rabies in insectivorous bats. I. Role of brown adipose tissue. J Exp Med. 1959 Sep;1;110:369-88.

Superti, F, Seganti L, Tsiang H, Orsi N. Role of phospholipids in rhabdovirus attachment to CER cells. Brief Report. Arch Virol. 1984; 81: p. 321.

Superti F, Hauttecoeur B, Morelec MJ, Goldoni P, Bizzini B, Tsiang H. Involvement of gangliosides in rabies virus infection. J Gen Virol. 1986 Jan;67(Pt 1):47-56.

Szanto AG, Nadin-Davis SA, White BN. Complete genome sequence of a raccoon rabies virus isolate. Virus Res. 2008 Sep;136(1-2):130-9. doi: 10.1016/j.virusres.2008.04.029.

Taddei VA. Sistemática de quirópteros. Boletim Instituto Pasteur, São Paulo. 1996;1(2):3-15.

Tamura K, Dudley J, Nei M, Kumar S. MEGA4: Molecular Evolutionary Genetics Analysis (MEGA) software version 4.0. Molecular Biology and Evolution. 2007;24:1596-9.

Tordo N, Poch C, Ermine A, Keith G. Primary structure of leader RNA and nucleoprotein genes of the rabies genome: Segmented homology with VSV. Nucleic Acids Res. 1986a;14: 2671-83.

Tordo N, Poch O, Ermine A, Keith G, Rougeon F. Walking along the rabies genome: is the large G-L intergenic region a remnant gene? Proc Natl Acad Sci USA. 1986b Jun;83(11):3914-8.

Tordo, N. Characteristics and molecular biology of rabies vírus. In: Meslin, FX, Kaplan, MM, Koprowski, H. Laboratory techniques in rabies. Genebra: World Health Organization; 1996. p. 28-51.

Torres S, Queiroz Lima E. A raiva e sua transmissão por morcegos hematóphagos infectados naturalmente. Revista Depto Nacional Produção Animal. 1935;2:1-55.

Torres S, Queiroz Lima E. A raiva e os morcegos hematóphagos. Morcegos que resistem a infecção tornam-se portadores e eliminadores do vírus? Revista Depto Nacional Produção Animal. 1936;3:165-74.

Uieda W, Hayashi MM, Gomes LH, Silva MMS. Espécies de quirópteros diagnosticadas com raiva no Brasil. Boletim Instituto Pasteur, São Paulo. 1996;1(2):17-35. 
Van Zyl N, Markotter W, Nel LH. Evolutionary history of African mongoose rabies. Virus Res. 2010 Jun;150(1-2):93-102.

Velasco-Villa A, Gomez-Sierra M, Hernandez-Rodriguez G, Juarez-Islas V, Melendez-Felix A, Vargas-Pino F, Velazquez-Monroy O, Flisser A. Antigenic diversity and distribution of rabies virus in Mexico. J Clin Microbiol. 2002 Mar;40(3):951-8.

Venters HD, Hoffert WR, Schatterday JE, Hardy AV. Rabies in bats in Florida. Am J Public Health. 1954 Feb;44(2):182-5.

Von Teichman BF, De Koker WC, Bosh SJ, Bishop GC, Meredith CD, Bingham J. Mokola virus infection: description of recent South Africa cases and review of the virus epidemiology. J S Afr Vet Assoc. 1998;69(4):169-71.

Warner CK, Zaki SR, Shieh WJ, Whitfield SG, Smith JS, Orciari LA, Shaddock JH, Niezgoda M, Wright CW, Goldsmith CS, Sanderlin DW, Yager PA, Rupprech CE. Laboratory investigation of human deaths from vampire bat rabies in Peru. Am J Trop Med Hyg. 1999;60(3):502-7.

Warrel DA. The clinical picture of rabies in man. Trans $\mathrm{R}$ Soc Trop Med Hyg. 1976;70(3):188-95.

Wiktor TJ, Fernandes MV, Koprowski H. Cultivation of rabies virus in human diploid cell strain WI-38. J Immunol. 1964;93:353-66.

World Health Organization. World survey of rabies no. 32 for the Year 1996. Geneva: The Organization.

World Health Organization. The World Survey for Rabies N³5 for the year 1999. Geneva: The Organization; 2000.

World Health Organization. WHO Expert Consultation on Rabies. WHO Technical Report Series 931. Geneva: The Organization; 2005. Available from: http://www.who.int/rabies/trs931_\%2006_05.pdf. [2006 Ago 18].

World Health Organization. WHO. 2009. Available from: http://www.who.int/rabies/Global_Rabies_ITH_2008.png [2011 Feb 15]. 
Willoughby RE Jr, Tieves KS, Hoffman GM, Ghanayem NS, Amlie-Lefond CM, Schwabe MJ, Chusid MJ, Rupprecht CE. Survival after treatment of rabies with induction of coma. $N$ Engl J Med. 2005 Jun;16;352(24):2508-14.

Wu X, Franka R, Velasco-Villa A, Rupprecht CE. Are all lyssavirus genes equal for phylogenetic analyses? Virus Res. 2007 Nov;129(2):91-103.

Wu X, Hu R, Zhang Y, Dong G, Rupprecht CE. Reemerging rabies and lack of systemic surveillance in People's Republic of China. Emerg Infect Dis. 2009 Aug;15(8):1159-64.

Wunner WH, Reagan KJ, Koprowski H. Characterization of saturable binding sites for rabies virus. J Virol. 1984 Jun;50(3):691-7.

Wunner WH, Dietzschold B, Smith CL, Lafon M, Golub E. Antigenic variants of CVS rabies virus with altered glycosylation sites. Virology. 1985 Jan;140(1):1-12.

Wunner WH. Rabies virus. In: Jackson AC, Wunner WH. Rabies. San Diego: Academic Press; 2002. p. 23-77.

Wunner WH. Rabies virus. In: Jackson AC, Wunner WH. Rabies. $2^{\text {nd }}$ ed. San Diego: Academic Press; 2002. p. 23-68.

Yung V, Favi M, Fernandez J. Genetic and antigenic typing of rabies virus in Chile. Brief report. Arch Virol. 2002 Nov;147(11):2197-205.

Zhengli S. Bat and virus. Protein Cell. 2010 Feb;1(2):109-14.

Zwickl DJ. Genetic algorithm approaches for the phylogenetic analysis of large biological sequence datasets under the Maximum Likelihood criterion. Ph.D. Thesis, Texas: The University of Texas at Austin; 2006. 


\section{ANEXOS}

\section{ANEXO A - Sequências utilizadas nas análises filogenéticas dos genes N, P, M, G e L}

\begin{tabular}{|c|c|c|c|}
\hline $\mathbf{N}^{\circ}$ Acesso GenBank & Identificação (Hospedeiro / Linhagem) & Origem & Gene \\
\hline NC_001542 & Rabies PV / Amostra de referência & França & $\mathrm{N}, \mathrm{P}, \mathrm{M}, \mathrm{G}$ e L \\
\hline \multirow[t]{2}{*}{$\begin{array}{l}\text { GU592649 / GU592650 / } \\
\text { GU592651 / GU592652 / } \\
\text { GU592654 }\end{array}$} & brbvusp01/06 / Bos taurus & Brasil & $\mathrm{N}, \mathrm{P}, \mathrm{M}, \mathrm{G}$ e $\mathrm{L}$ \\
\hline & brsgusp32 07 / Callithrix jacchus & Brasil & $\mathrm{N}, \mathrm{P}, \mathrm{M} \mathrm{e} \mathrm{G}$ \\
\hline GU592648 & brdrusp100/07 / Desmodus rotundus & Brasil & $\mathrm{N}, \mathrm{P}, \mathrm{M}, \mathrm{G}$ e L \\
\hline AB009663 & Rabies virus RC-HL / linhagem vacinal & Japão & $\mathrm{N}, \mathrm{P}, \mathrm{M}, \mathrm{G}$ e L \\
\hline AB083792 & Rabies virus strain $\operatorname{dg} 2$ / Canis familiaris & Brasil & $\mathrm{N}$ parcial \\
\hline AB083793 & Rabies virus strain BRct 3 / Felis catus & Brasil & $\mathrm{N}$ parcial \\
\hline AB083794 & Rabies virus strain BRct5 / Felis catus & Brasil & $\mathrm{N}$ parcial \\
\hline AB083795 & Rabies virus strain BRhm6 / Homo sapiens & Brasil & $\mathrm{N}$ parcial \\
\hline AB083796 & Rabies virus strain BRdg10 / Canis familiaris & Brasil & $\mathrm{N}$ parcial \\
\hline $\mathrm{AB} 083797$ & Rabies virus strain BRdg12 / Canis familiaris & Brasil & $\mathrm{N}$ parcial \\
\hline AB083798 & Rabies virus strain BRdg15 / Canis familiaris & Brasil & N parcial \\
\hline AB083799 & Rabies virus strain BRbv17 / Bos taurus & Brasil & $\mathrm{N}$ parcial \\
\hline $\mathrm{AB} 083800$ & Rabies virus strain BRhr18 / equino & Brasil & $\mathrm{N}$ parcial \\
\hline AB083801 & Rabies virus strain BRhm23 / Homo sapiens & Brasil & N parcial \\
\hline AB083802 & Rabies virus strain BRpg28 / suíno & Brasil & N parcial \\
\hline AB083803 & Rabies virus strain BRbv30 / Bos taurus & Brasil & N parcial \\
\hline AB083804 & Rabies virus strain BRhr31 / equino & Brasil & N parcial \\
\hline AB083805 & Rabies virus strain BRbv32 / Bos taurus & Brasil & N parcial \\
\hline AB083806 & Rabies virus strain BRvmbt33 / Desmodus rotundus & Brasil & N parcial \\
\hline AB083807 & Rabies virus strain BRvmbt34 / Desmodus rotundus & Brasil & $\mathrm{N}$ parcial \\
\hline AB083808 & Rabies virus strain BRsp35 & Brasil & N parcial \\
\hline AB083809 & Rabies virus strain BRbv36/ Bos taurus & Brasil & $\mathrm{N}$ parcial \\
\hline AB083810 & Rabies virus strain BRbv38 / Bos taurus & Brasil & $\mathrm{N}$ parcial \\
\hline $\mathrm{AB} 083811$ & Rabies virus strain BRbv39 / Bos taurus & Brasil & $\mathrm{N}$ parcial \\
\hline $\mathrm{AB} 083812$ & Rabies virus strain BRvmbt41 / Desmodus rotundus & Brasil & N parcial \\
\hline $\mathrm{AB} 083813$ & Rabies virus strain BRbv43 / Bos taurus & Brasil & N parcial \\
\hline AB083814 & Rabies virus strain BRbv45 / Bos taurus & Brasil & N parcial \\
\hline AB083815 & Rabies virus strain BRvmbt46 / Desmodus rotundus & Brasil & $\mathrm{N}$ parcial \\
\hline AB083816 & Rabies virus strain BRvmbt47 / Desmodus rotundus & Brasil & N parcial \\
\hline $\mathrm{AB} 083817$ & Rabies virus strain BRbv49/Bos taurus & Brasil & N parcial \\
\hline $\mathrm{AB} 083818$ & Rabies virus strain BRbv50/ Bos taurus & Brasil & $\mathrm{N}$ parcial \\
\hline AB085828 & Rabies virus strain HEP_Flury / linhagem vicinal & Japão & $\mathrm{N}$ parcial \\
\hline AB010494 & Rabies virus Nishigahara N / linhagem vacinal & Japão & $\mathrm{N}$ \\
\hline AB044824 & Rabies strain Nishigahara / linhagem vacinal & Japão & $\mathrm{N}, \mathrm{P}, \mathrm{M}, \mathrm{G}$ e L \\
\hline AB052666 & Rabies virus glycoprotein / Canis familiaris & Tailandia & $\mathrm{G}$ \\
\hline AB085828 & Rabies strain HEP Flury / linhagem vacinal & Japão & $\mathrm{N}, \mathrm{P}, \mathrm{M}, \mathrm{G}$ e L \\
\hline AB 110656 & Rabies virus BRct 3 / Felis catus & Brasil & G \\
\hline AB 110657 & Rabies virus BRhm6 / Homo sapiens & Brasil & $\mathrm{G}$ \\
\hline $\mathrm{AB} 110658$ & Rabies virus BRdg10 / Canis familiaris & Brasil & $\mathrm{G}$ \\
\hline $\mathrm{AB} 110660$ & Rabies virus BRhr18 / equino & Brasil & G \\
\hline $\mathrm{AB} 110661$ & Rabies virus BRpg28 / suíno & Brasil & $\mathrm{G}$ \\
\hline
\end{tabular}




\begin{tabular}{|c|c|c|c|}
\hline $\mathrm{N}^{0}$ Acesso GenBank & Identificação (Hospedeiro / Linhagem) & Origem & Gene \\
\hline AB110662 & Rabies virus BRhr31 / equino & Brasil & G \\
\hline AB110663 & Rabies virus BRbv32 / Bos taurus & Brasil & G \\
\hline AB110664 & Rabies virus BRvmbt 33 / morcego hematófago & Brasil & G \\
\hline AB110665 & Rabies virus BRsp35 / ovino & Brasil & G \\
\hline AB110666 & Rabies virus BRbv39 / Bos taurus & Brasil & G \\
\hline $\mathrm{AB} 110667$ & Rabies virus BRbv45 / Bos taurus & Brasil & G \\
\hline AB110668 & Rabies virus BRbv49/ Bos taurus & Brasil & G \\
\hline AB110669 & Rabies virus BRbv50 / Bos taurus & Brasil & G \\
\hline $\mathrm{AB} 115921$ & Rabies virus glycoprotein / Canis familiaris & Indonésia & G \\
\hline $\begin{array}{l}\text { AB117969 / AB291078 / } \\
\text { AB291108 }\end{array}$ & Rabies virus BR AL1 / Artibeus lituratus & Brasil & $\mathrm{N}, \mathrm{M}$ e $\mathrm{P}$ \\
\hline $\begin{array}{l}\text { AB117970 / AB291079 / } \\
\text { AB291109 }\end{array}$ & Rabies virus BR AL2 / Artibeus lituratus & Brasil & $\mathrm{N}, \mathrm{M}$ e P \\
\hline $\begin{array}{l}\text { AB117971 / AB291080 / } \\
\text { AB291110 }\end{array}$ & Rabies virus BR AL3 / Artibeus lituratus & Brasil & $\mathrm{N}, \mathrm{M}$ e P \\
\hline $\begin{array}{l}\mathrm{AB} 117972 \text { / AB291081 / } \\
\mathrm{AB} 291111 / \mathrm{AB} 496697\end{array}$ & Rabies virus BR AP1 / Artibeus planirostris & Brasil & $\mathrm{N}, \mathrm{M}, \mathrm{Pe} \mathrm{G}$ \\
\hline $\mathrm{AB} 128149$ & Rabies strain Ni CE / linhagem vacinal & Japão & $\mathrm{N}, \mathrm{P}, \mathrm{M}, \mathrm{G}$ e L \\
\hline $\mathrm{AB} 201811$ & Rabies virus / Eptesicus_furinalis & Brasil & $\mathrm{N}$ parcial \\
\hline AB201812 & Rabies virus / Eptesicus furinalis & Brasil & $\mathrm{N}$ parcial \\
\hline $\begin{array}{l}\text { AB247412 / AB291088 / } \\
\text { AB291118 }\end{array}$ & Rabies virus BRdg317 / Canis familiaris & Brasil & G, M e P \\
\hline $\mathrm{AB} 247414$ & Rabies virus BRdg322 / Canis familiaris & Brasil & G \\
\hline AB247419 & Rabies virus BRdg666 / Canis familiaris & Brasil & G \\
\hline $\begin{array}{l}\text { AB247421 / AB291092 / } \\
\text { AB291122 }\end{array}$ & Rabies virus BR DR1 / Desmodus rotundus & Brasil & G, M e P \\
\hline $\begin{array}{l}\text { AB247422 / AB291093 / } \\
\text { AB291123 }\end{array}$ & Rabies virus BR DR2 / Desmodus rotundus & Brasil & G, M e P \\
\hline $\begin{array}{l}\text { AB247423 / AB291094 / } \\
\text { AB291124 }\end{array}$ & Rabies virus BR DR3 / Desmodus rotundus & Brasil & G, M e P \\
\hline AB247425 & Rabies virus BR DR5 / Desmodus rotundus & Brasil & G \\
\hline AB247428 & Rabies virus BR DR8 / Desmodus rotundus & Brasil & G \\
\hline AB247431 & Rabies virus BRfx 240 / raposa & Brasil & G \\
\hline $\begin{array}{l}\text { AB247433 / AB291105 / } \\
\text { AB29135 }\end{array}$ & Rabies virus BRfx242 / cachorro do mato (Dusicyon sp.) & Brasil & G, M e P \\
\hline AB247437 & Rabies virus BRfx248 / raposa & Brasil & G \\
\hline AB276307 & Rabies virus BRhm16/ Homo sapiens & Brasil & G \\
\hline AB276308 & Rabies virus BRdg101 / Canis familiaris & Brasil & G \\
\hline AB276309 & Rabies virus BRct112 / Felis catus & Brasil & G \\
\hline $\mathrm{AB} 276310$ & Rabies virus BRct116/ Felis catus & Brasil & G \\
\hline AB276311 & Rabies virus BRhm528 / Homo sapiens & Brasil & G \\
\hline AB276312 & Rabies virus BRhm529/ Homo sapiens & Brasil & G \\
\hline $\mathrm{AB} 276313$ & Rabies virus BRhm530 / Homo sapiens & Brasil & G \\
\hline AB276314 & Rabies virus BRhm531 / Homo sapiens & Brasil & G \\
\hline AB276315 & Rabies virus BRhm671 / Homo sapiens & Brasil & G \\
\hline AB291082 / AB291112 & Rabies virus BRbv303 / Bos taurus & Brasil & $\mathrm{M} \mathrm{e} \mathrm{P}$ \\
\hline AB291083 / AB291113 & Rabies virus BRbv306/ Bos taurus & Brasil & $\mathrm{M}$ e $\mathrm{P}$ \\
\hline AB291084 / AB291114 & Rabies virus BRct $112 /$ Felis catus & Brasil & $\mathrm{M}$ e $\mathrm{P}$ \\
\hline AB291085 / AB291115 & Rabies virus BRct $116 /$ Felis catus & Brasil & $\mathrm{M}$ e $\mathrm{P}$ \\
\hline AB291086 / AB291116 & Rabies virus BRct333 / Felis catus & Brasil & $\mathrm{Me} \mathrm{P}$ \\
\hline AB291087 / AB291117 & Rabies virus BRdg101 / Canis familiaris & Brasil & $\mathrm{M}$ e P \\
\hline AB291089 / AB291119 & Rabies virus BRdg335 / Canis familiaris & Brasil & $\mathrm{M}$ e $\mathrm{P}$ \\
\hline AB291090 / AB291120 & Rabies virus BRdg96 / Canis familiaris & Brasil & $\mathrm{M}$ e $\mathrm{P}$ \\
\hline
\end{tabular}




\begin{tabular}{|c|c|c|c|}
\hline No Acesso GenBank & Identificação (Hospedeiro / Linhagem) & Origem & Gene \\
\hline AB291091 / AB291121 & Rabies virus BRdg97 / Canis familiaris & Brasil & M e P \\
\hline $\begin{array}{l}\text { AB291095 / AB291125 / } \\
\text { AB383168 }\end{array}$ & Rabies virus BR EF1 / Eptesicus furinalis & Brasil & $\mathrm{M}, \mathrm{Pe} \mathrm{G}$ \\
\hline $\begin{array}{l}\text { AB291096 / AB291126 / } \\
\text { AB383169 }\end{array}$ & Rabies virus BR EF2 / Eptesicus furinalis & Brasil & M, P e G \\
\hline $\begin{array}{l}\text { AB291097 / AB291127 / } \\
\text { AB383170 }\end{array}$ & Rabies virus BR EF3 / Eptesicus furinalis & Brasil & M, P e G \\
\hline $\begin{array}{l}\text { AB291098 / AB291128 / } \\
\text { AB383171 }\end{array}$ & Rabies virus BR EF4 / Eptesicus furinalis & Brasil & M, P e G \\
\hline AB291099 / AB291129 & Rabies virus BR MM1 / Molossus molossus & Brasil & M e P \\
\hline AB291100 / AB291130 & Rabies virus BR MM1 / Molossus molossus & Brasil & $\mathrm{Me} P$ \\
\hline AB291101 / AB291131 & Rabies virus BR NL1 / Nyctinomops laticaudatus & Brasil & $\mathrm{M} \mathrm{e} \mathrm{P}$ \\
\hline AB291102 / AB291132 & Rabies virus BR NL3 / Nyctinomops laticaudatus & Brasil & M e P \\
\hline AB291103 / AB291133 & cachorro do mato (Dusicyon sp.) & Brasil & M e P \\
\hline AB291104 AB291134 & cachorro do mato (Dusicyon sp.) & Brasil & $\mathrm{M} \mathrm{e} \mathrm{P}$ \\
\hline AB291106 / AB291136 & cachorro do mato (Dusicyon sp.) & Brasil & $\mathrm{M}$ e $\mathrm{P}$ \\
\hline AB291107 / AB291137 & cachorro do mato (Dusicyon sp.) & Brasil & $\mathrm{M}$ e P \\
\hline AB362483 & Rabies strain BR Pfx1 / Dusicyon sp. & Brasil & $\mathrm{N}, \mathrm{P}, \mathrm{M}, \mathrm{G}$ e L \\
\hline AB373639 & Rabies virus BR BAT15 / morcego & Brasil & G \\
\hline AB373640 & Rabies virus BR BAT16 / morcego & Brasil & G \\
\hline AB373641 & Rabies virus m28 07 / Bos taurus & Brasil & G \\
\hline AB383162 & Rabies virus BR BAT3 / morcego & Brasil & G \\
\hline AB383163 & Rabies virus BR BAT15 / morcego não hematófago & Brasil & G \\
\hline AB383164 & Rabies virus BR BAT16 / morcego não hematófago & Brasil & G \\
\hline AB383165 & Rabies virus BR BAT28 / morcego não hematófago & Brasil & G \\
\hline AB383166 & Rabies virus BR BAT29 / morcego não hematófago & Brasil & G \\
\hline AB383167 & Rabies virus BR EA1 / Eumops auripendulus & Brasil & G \\
\hline AB383172 & Rabies virus BR NL2 / Nyctinomops laticaudatus & Brasil & G \\
\hline AB428315 & Rabies virus CHbv9 / Bos taurus & China & G \\
\hline AB428322 / AB428333 & Rabies virus strain CHbv7 / Bos taurus & China & $\mathrm{M} \mathrm{e} P$ \\
\hline AB458794 & Rabies virus strain CHdg15 / Canis lupus familiaris & China & $\mathrm{P}$ \\
\hline AB458796 / AB505888 & Rabies virus strain CHdg18 / Canis lupus familiaris & China & $\mathrm{Pe} \mathrm{M}$ \\
\hline AB496676 & Rabies virus BR A1 / Artibeus sp. & Brasil & G \\
\hline AB496677 & Rabies virus BR A2 / Artibeus sp. & Brasil & G \\
\hline AB496678 & Rabies virus BR AF1 / Artibeus fimbriatus & Brasil & G \\
\hline AB496679 & Rabies virus BR AF2 / Artibeus fimbriatus & Brasil & G \\
\hline AB496680 & Rabies virus BR AL4 / Artibeus lituratus & Brasil & G \\
\hline AB496681 & Rabies virus BR AL7 / Artibeus lituratus & Brasil & G \\
\hline AB496682 & Rabies virus BR AL8 / Artibeus lituratus & Brasil & G \\
\hline AB496683 & Rabies virus BR AL9 / Artibeus lituratus & Brasil & G \\
\hline AB496684 & Rabies virus BR AL10 / Artibeus lituratus & Brasil & G \\
\hline AB496685 & Rabies virus BR AL11 / Artibeus lituratus & Brasil & G \\
\hline AB496686 & Rabies virus BR AL12 / Artibeus lituratus & Brasil & G \\
\hline AB496687 & Rabies virus BR AL13 / Artibeus lituratus & Brasil & G \\
\hline AB496688 & Rabies virus BR AL14 / Artibeus lituratus & Brasil & G \\
\hline AB496689 & Rabies virus BR AL15 / Artibeus lituratus & Brasil & G \\
\hline $\mathrm{AB} 496690$ & Rabies virus BR AL16 / Artibeus lituratus & Brasil & G \\
\hline AB496691 & Rabies virus BR AL17 / Artibeus lituratus & Brasil & G \\
\hline AB496692 & Rabies virus BR AL18 / Artibeus lituratus & Brasil & G \\
\hline
\end{tabular}




\begin{tabular}{|c|c|c|c|}
\hline No Acesso GenBank & Identificação (Hospedeiro / Linhagem) & Origem & Gene \\
\hline AB496693 & Rabies virus BR AL19/ Artibeus lituratus & Brasil & G \\
\hline AB496694 & Rabies virus BR AL20 / Artibeus lituratus & Brasil & $\mathrm{G}$ \\
\hline AB496695 & Rabies virus BR AL21 / Artibeus lituratus & Brasil & $\mathrm{G}$ \\
\hline AB496696 & Rabies virus BR AL22 / Artibeus lituratus & Brasil & G \\
\hline AB496698 & Rabies virus BR DR10 / Desmodus rotundus & Brasil & $\mathrm{G}$ \\
\hline AB496699 & Rabies virus BR DR11 / Desmodus rotundus & Brasil & $\mathrm{G}$ \\
\hline AB496700 & Rabies virus BR DR12 / Desmodus rotundus & Brasil & $\mathrm{G}$ \\
\hline AB496701 & Rabies virus BR DR13 / Desmodus rotundus & Brasil & $\mathrm{G}$ \\
\hline AB496702 & Rabies virus BR DR14 / Desmodus rotundus & Brasil & $\mathrm{G}$ \\
\hline AB496703 & Rabies virus BR DR16 / Desmodus rotundus & Brasil & G \\
\hline AB496704 & Rabies virus BR DR19/ Desmodus rotundus & Brasil & G \\
\hline AB496705 & Rabies virus BR DR20 / Desmodus rotundus & Brasil & G \\
\hline AB505882 & Rabies strain CHdg11 / Canis familiaris & China & $\mathrm{M}$ \\
\hline AB505888 & Rabies strain CHdg18 / Canis familiaris & China & M \\
\hline AB518487 & Rabies virus BRct9 / Felis silvestris catus & Brasil & G \\
\hline AB518488 & Rabies virus BRct 22 / Felis silvestris catus & Brasil & $\mathrm{G}$ \\
\hline AB518493 & Rabies virus BRdg640 / Canis lupus familiaris & Brasil & $\mathrm{G}$ \\
\hline AB518495 & Rabies virus BRdg652 / Canis lupus familiaris & Brasil & G \\
\hline AB571001 & Rabies virus isolate MG 17 / Bos taurus & Mongólia & $\mathrm{N}$ \\
\hline AB571009 & Rabies isolate MGL 27 / Vulpes vulpes & Mongólia & $\mathrm{N}$ \\
\hline AF033905 & Rabies virus strain 9616FRA & França & $\mathrm{N}$ \\
\hline AF045166 & Rabies virus pehm 3230 / Homo sapiens & Peru & $\mathrm{N}$ \\
\hline AF070449 & Rabies virus natural host Desmodus rotundus & Brasil & $\mathrm{N}$ \\
\hline AF070450 & Rabies virus natural host Tadarida brasiliensis & Chile & $\mathrm{N}$ \\
\hline AF155039 & Rabies virus strain $3 \mathrm{AG}$ & China & $\mathrm{N}$ \\
\hline AF351827 & Rabies virus isolate EF1 / Eptesicus fuscus & Canadá & $\mathrm{N}$ \\
\hline AF351828 & Rabies virus isolate EF32 / Eptesicus fuscus & Canadá & $\mathrm{N}$ \\
\hline AF351829 & Rabies virus isolate EF33 / Eptesicus fuscus & Canadá & $\mathrm{N}$ \\
\hline AF351830 & Rabies virus isolate EF22 / Eptesicus fuscus & Canadá & $\mathrm{N}$ \\
\hline AF351831 & Rabies virus isolate EF31 / Eptesicus fuscus & Canadá & $\mathrm{N}$ \\
\hline AF351832 & Rabies virus isolate EF34 / Eptesicus fuscus & Canadá & $\mathrm{N}$ \\
\hline AF351833 & Rabies virus isolate EF12 / Eptesicus fuscus & Canadá & $\mathrm{N}$ \\
\hline AF351834 & Rabies virus isolate ML5 */Lasionycteris noctivagans & Canadá & $\mathrm{N}$ \\
\hline AF351835 & Rabies virus isolate ME1 / Myotis evotis & Canadá & $\mathrm{N}$ \\
\hline AF351836 & Rabies virus isolate MC2 / Myotis californicus & Canadá & $\mathrm{N}$ \\
\hline AF351837 & Rabies virus isolate ML7 */Lasionycteris noctivagans & Canadá & $\mathrm{N}$ \\
\hline AF351838 & Rabies virus isolate ML6 / Myotis lucifugus & Canadá & $\mathrm{N}$ \\
\hline AF351839 & Rabies virus isolate ML4 / Myotis lucifugus & Canadá & $\mathrm{N}$ \\
\hline AF351840 & Rabies virus isolate LAN12 / Lasionycteris noctivagans & Canadá & $\mathrm{N}$ \\
\hline AF351841 & Rabies virus isolate LAN13 / Lasionycteris noctivagans & Canadá & $\mathrm{N}$ \\
\hline AF351842 & Rabies virus isolate LAN8 / Lasionycteris noctivagans & Canadá & $\mathrm{N}$ \\
\hline $\mathrm{AF} 351843$ & Rabies virus isolate LI / Lasiurus intermedius & Estados Unidos & $\mathrm{N}$ \\
\hline AF351844 & Rabies virus isolate LB1 / Lasiurus borealis & Canadá & $\mathrm{N}$ \\
\hline AF351845 & Rabies virus isolate LC1 / Lasiurus cinereus & Canadá & $\mathrm{N}$ \\
\hline AF351846 & Rabies virus isolate LC2 / Lasiurus cinereus & Canadá & $\mathrm{N}$ \\
\hline AF351847 & Rabies virus isolate DR Braz / Bos taurus & Brasil & $\mathrm{N}$ \\
\hline
\end{tabular}




\begin{tabular}{|c|c|c|c|}
\hline No Acesso GenBank & Identificação (Hospedeiro / Linhagem) & Origem & Gene \\
\hline AF351848 & Rabies virus isolate CF1 / Canis familiaris & Canadá & $\mathrm{N}$ \\
\hline AF351849 & Rabies virus isolate TB1 / Tadarida brasiliensis & Estados Unidos & $\mathrm{N}$ \\
\hline AF351850 & Rabies virus isolate IB Ch / morcego insetívoro & Chile & $\mathrm{N}$ \\
\hline AF351851 & Rabies virus isolate VV2 / Vulpes vulpes & Canadá & $\mathrm{N}$ \\
\hline $\mathrm{AF} 351852$ & Rabies virus isolate DRTd2 / Bos taurus & Trinidad & $\mathrm{N}$ \\
\hline $\mathrm{AF} 351853$ & Rabies virus isolate EF55 / Eptesicus fuscus & Canadá & $\mathrm{N}$ \\
\hline $\mathrm{AF} 351855$ & Rabies virus isolate EF19 / Eptesicus fuscus & Canadá & $\mathrm{N}$ \\
\hline AF351856 & Rabies virus isolate LB6 / Lasiurus borealis & Canadá & $\mathrm{N}$ \\
\hline AF351857 & Rabies virus isolate LB7 / Lasiurus borealis & Estados Unidos & $\mathrm{N}$ \\
\hline $\mathrm{AF} 351858$ & Rabies virus isolate LC8 / Lasiurus cinereus & Canadá & $\mathrm{N}$ \\
\hline AF351859 & Rabies virus isolate EF57 / Eptesicus fuscus & Canadá & $\mathrm{N}$ \\
\hline AF351860 & Rabies virus isolate EF71 / Eptesicus fuscus & Estados Unidos & $\mathrm{N}$ \\
\hline AF351861 & Rabies virus isolate EF3 / Eptesicus fuscus & Canadá & $\mathrm{N}$ \\
\hline AF351862 & Rabies virus isolate EF40 / Eptesicus fuscus & Canadá & $\mathrm{N}$ \\
\hline AF360850 / L20673 & Rabies virus RAVN1578SK Arctic fox 91RABN1578 / Vulpes vulpes & Canadá & $\mathrm{MeN}$ \\
\hline AF360853 & Rabies virus 90RABN9196 / Vulpes vulpes & Canadá & $\mathrm{M}$ \\
\hline AF360855 & Rabies virus 93RABN1090 / Alopex lagopus & Canadá & $\mathrm{M}$ \\
\hline AF360856 & Rabies virus V125 / Procyon lotor & Canadá & M \\
\hline AF360857 & Rabies virus NY516 / Procyon lotor & Canadá & $\mathrm{M}$ \\
\hline AF369264 & Rabies virus V001DG / linhagem vacinal & Canadá & $\mathrm{P}$ \\
\hline AF369323 & Rabies virus V015 / Canis familiaris & América do Sul & $\mathrm{P}$ \\
\hline AF369338 & Rabies virus 93ON0058BB / Eptesicus fuscus & Canadá & $\mathrm{P}$ \\
\hline AF369339 & Rabies virus 93ON2994BB / Eptesicus fuscus & Canadá & $\mathrm{P}$ \\
\hline AF369340 & Rabies virus 89SK1461BB / Eptesicus fuscus & Canadá & $\mathrm{P}$ \\
\hline AF369341 & Rabies virus 88BC1319BB / Eptesicus fuscus & Canadá & $\mathrm{P}$ \\
\hline AF369342 & Rabies virus V230.BBB / Eptesicus fuscus & Estados Unidos & $\mathrm{P}$ \\
\hline AF369343 & Rabies virus V089.LBB / Myotis $s p$. & Canadá & $\mathrm{P}$ \\
\hline AF369344 & Rabies virus 4887.LBB / Myotis $s p$. & Canadá & $\mathrm{P}$ \\
\hline AF369345 & Rabies virus 4398.SHB / Lasionycteris noctivagans & Canadá & $\mathrm{P}$ \\
\hline AF369346 & Rabies virus V077.SHB / Lasionycteris noctivagans & Canadá & $\mathrm{P}$ \\
\hline AF369347 & Rabies virus V103.HB / Laciurus cinereus & Canadá & $\mathrm{P}$ \\
\hline AF369348 & Rabies virus V231.RB / Lasiurus borealis & Estados Unidos & $\mathrm{P}$ \\
\hline AF369349 & Rabies virus 3694.MYO / Myotis sp. & Canadá & $\mathrm{P}$ \\
\hline AF369350 & Rabies virus 95ON4905BB / Eptesicus fuscus & Canadá & $\mathrm{P}$ \\
\hline AF369351 & Rabies virus 6832.RB Lasiurus borealis & Canadá & $\mathrm{P}$ \\
\hline AF369352 & Rabies virus 7890.LBB / Myotis sp. & Canadá & $\mathrm{P}$ \\
\hline AF369353 & Rabies virus 9499.MYO / Myotis sp. & Canadá & $\mathrm{P}$ \\
\hline AF369354 & Rabies virus V102.MYO / Myotis sp. & Canadá & $\mathrm{P}$ \\
\hline AF369355 & Rabies virus 89SK2317BB / Eptesicus fuscus & Canadá & $\mathrm{P}$ \\
\hline AF369356 & Rabies virus V158.SHB Lasionycteris noctivagans & Canadá & $\mathrm{P}$ \\
\hline AF369357 & Rabies virus 93BC1950BB / Eptesicus fuscus & Canadá & $\mathrm{P}$ \\
\hline AF369358 & Rabies virus V179.LBB / Myotis sp. & Canadá & $\mathrm{P}$ \\
\hline AF369359 & Rabies virus V235.FTB / Tadarida brasiliensis & Estados Unidos & $\mathrm{P}$ \\
\hline AF369360 & Rabies virus V013.IB / morcego Insetívoro & América do Sul & $\mathrm{P}$ \\
\hline AF369361 & Rabies virus A1.IB / morcego Insetívoro & América do Sul & $\mathrm{P}$ \\
\hline AF369362 & Rabies virus V229.VB / Desmodus rotundus & América do Sul & $\mathrm{P}$ \\
\hline
\end{tabular}




\begin{tabular}{|c|c|c|c|}
\hline No Acesso GenBank & Identificação (Hospedeiro / Linhagem) & Origem & Gene \\
\hline AF369363 & Rabies virus P10.VB / Desmodus rotundus & América do Sul & $\mathrm{P}$ \\
\hline AF369364 & Rabies virus P4.VB / Desmodus rotundus & América do Sul & $\mathrm{P}$ \\
\hline AF369365 & Rabies virus B2.VB / Desmodus rotundus & América do Sul & $\mathrm{P}$ \\
\hline AF369366 & Rabies virus M4.VB / Desmodus rotundus & América do Sul & $\mathrm{P}$ \\
\hline AF369367 & Rabies virus V324.VB / Desmodus rotundus & América do Sul & $\mathrm{P}$ \\
\hline AF369368 & Rabies virus V325.VB / Desmodus rotundus & América do Sul & $\mathrm{P}$ \\
\hline AF499686 & Rabies strain SRV9 / linhagem vacinal & China & $\mathrm{N}, \mathrm{P}, \mathrm{M}, \mathrm{G}$ e L \\
\hline AF533786 & Rabies virus CH_TB1271/Tadarida brasiliensis & Chile & $\mathrm{N}$ parcial \\
\hline AF533800 & Rabies virus CH_TB3851 / Tadarida brasiliensis & Chile & $\mathrm{N}$ parcial \\
\hline AF533804 & Rabies virus CH_TB4009 / Tadarida brasilensis & Chile & $\mathrm{N}$ parcial \\
\hline AF533813 & Rabies virus CHMy149 / Myotis sp. & Chile & $\mathrm{N}$ parcial \\
\hline AF533814 & Rabies virus CHLas2063 / Lasiurus sp. & Chile & $\mathrm{N}$ parcial \\
\hline AF533824 & Rabies virus CH_CIHM4312 / Histiotus sp. & Chile & $\mathrm{N}$ parcial \\
\hline AF533828 & Rabies virus CHLbbt3589/ Lasiurus sp. & Chile & $\mathrm{N}$ parcial \\
\hline AY039224 & Rabies virus isolate 1428 / Lasiurus borealis & Estados Unidos & $\mathrm{N}$ \\
\hline AY039229 & Rabies virus isolate 132 / Eptesicus fuscus & Estados Unidos & $\mathrm{N}$ \\
\hline AY170397 & Rabies virus isolate 4862 / Eptesicus fuscus & Estados Unidos & $\mathrm{N}$ \\
\hline AY170400 & Rabies virus isolate usefu 4886 / Eptesicus fuscus & Estados Unidos & $\mathrm{N}$ \\
\hline AY170407 & Rabies virus isolate $5100 /$ skunk & Estados Unidos & $\mathrm{N}$ \\
\hline AY170409 & Rabies virus isolate 5440 / skunk & Estados Unidos & $\mathrm{N}$ \\
\hline AY170410 & Rabies virus isolate 5441 / skunk & Estados Unidos & $\mathrm{N}$ \\
\hline AY170413 & Rabies virus isolate 5450 / Eptesicus fuscus & Estados Unidos & $\mathrm{N}$ \\
\hline AY170415 & Rabies virus isolate usmsp4873 / Myotis sp. & Estados Unidos & $\mathrm{N}$ \\
\hline AY170416 & Rabies virus isolate 4872 / Myotis $s p$. & Estados Unidos & $\mathrm{N}$ \\
\hline AY170417 & Rabies virus isolate 4891 / Eptesicus fuscus & Estados Unidos & $\mathrm{N}$ \\
\hline AY233426 & Rabies virus / Tadarida brasiliensis & Argentina & $\mathrm{N}$ parcial \\
\hline AY233427 & Rabies virus / Tadarida brasiliensis & Argentina & $\mathrm{N}$ parcial \\
\hline AY257986 & Rabies virus HM88 / Homo sapiens & Tailândia & $\mathrm{P}$ \\
\hline AY352471 & Rabies virus isolate $3454 \mathrm{cow} /$ Bos taurus & Rússia & $\mathrm{N}$ \\
\hline AY654585 & Rabies virus / Homo sapiens & Brasil & $\mathrm{N}$ parcial \\
\hline AY654586 & Rabies virus / Callithrix jacchus & Brasil & $\mathrm{N}$ parcial \\
\hline AY654587 & Rabies vírus / Homo sapiens & Brasil & $\mathrm{N}$ parcial \\
\hline AY705373 & Rabies virus SHBRV 18 / Lasionycteris noctivagans & Estados Unidos & $\mathrm{N}, \mathrm{P}, \mathrm{M}, \mathrm{G}$ e L \\
\hline AY854595 & Rabies virus isolate V924 / Desmodus rotundus & México & $\mathrm{N}$ parcial \\
\hline AY956319 & Rabies virus organ recipient / Homo sapiens & Alemanha & $\mathrm{N}, \mathrm{P}, \mathrm{M}, \mathrm{G}$ e L \\
\hline D14873 & Rabies virus RAVRCHL / linhagem vacinal & Japão & G \\
\hline DQ011221 & Rabies virus strain 98 / linhagem vacinal & Colômbia & $\mathrm{P}$ \\
\hline DQ149104 & Rabies virus $4371 \mathrm{fx} /$ raposa & Brasil & $\mathrm{N}$ parcial \\
\hline DQ275559 & Rabies virus isolate V825 / Canis familiaris & Canadá & $\mathrm{P}$ \\
\hline DQ447947 & Rabies vírus / Homo sapiens & Brasil & $\mathrm{N}$ parcial \\
\hline DQ447948 & Rabies vírus / Cerdocyon thous & Brasil & $\mathrm{N}$ parcial \\
\hline DQ447966 & Rabies vírus / Homo sapiens & Brasil & $\mathrm{N}$ parcial \\
\hline DQ447968 & Rabies vírus / Homo sapiens & Brasil & $\mathrm{N}$ parcial \\
\hline DQ631835 & Rabies vírus / Eptesicus furinalis & Brasil & $\mathrm{N}$ parcial \\
\hline DQ631837 & Rabies vírus / Eptesicus furinalis & Brasil & $\mathrm{N}$ parcial \\
\hline DQ631838 & Rabies vírus / Eptesicus furinalis & Brasil & $\mathrm{N}$ parcial \\
\hline
\end{tabular}




\begin{tabular}{|c|c|c|c|}
\hline $\mathrm{N}^{0}$ Acesso GenBank & Identificação (Hospedeiro / Linhagem) & Origem & Gene \\
\hline DQ631839 & Rabies vírus / Eptesicus furinalis & Brasil & $\mathrm{N}$ parcial \\
\hline DQ875050 & Rabies strain MRV / linhagem vacinal & China & $\mathrm{N}, \mathrm{P}, \mathrm{M}, \mathrm{G}$ e L \\
\hline DQ875051 & Rabies strain DRV / linhagem vacinal & China & $\mathrm{N}, \mathrm{P}, \mathrm{M}$ e L \\
\hline EF152234 & Rabies vírus 10563 CthBA 03 / Cerdocyon thous & Brasil & $\mathrm{N}$ parcial \\
\hline EF152238 & Rabies virus $10568 \mathrm{ctPB} 03 /$ Felis catus & Brasil & $\mathrm{N}$ parcial \\
\hline EF152239 & Rabies virus $10564 \mathrm{ctPB} 03 /$ Felis catus & Brasil & $\mathrm{N}$ parcial \\
\hline EF152249 & Rabies virus $6968 \mathrm{dgPE} 05$ / Canis familiaris & Brasil & $\mathrm{N}$ parcial \\
\hline EF152254 & Rabies virus 6980CthPE 05 / Cerdocyon thous & Brasil & $\mathrm{N}$ parcial \\
\hline EF152261 & Rabies virus 9370dgPE 05 / Canis familiaris & Brasil & $\mathrm{N}$ parcial \\
\hline EF152263 & Rabies virus 9372dgPE 05 / Canis familiaris & Brasil & $\mathrm{N}$ parcial \\
\hline EF152264 & Rabies virus $10561 \mathrm{dgPB} 03$ / Canis familiaris & Brasil & $\mathrm{N}$ parcial \\
\hline EF152274 & Rabies virus 7579CthBA 05 / Cerdocyon thous & Brasil & $\mathrm{N}$ parcial \\
\hline EF152275 & Rabies virus 8257dgMA 05 / Canis familiaris & Brasil & $\mathrm{N}$ parcial \\
\hline EF152276 & Rabies virus $8575 \mathrm{dgPA} 05$ / Canis familiaris & Brasil & $\mathrm{N}$ parcial \\
\hline EF152280 & Rabies virus $9479 \mathrm{dgAL} 05$ / Canis familiaris & Brasil & $\mathrm{N}$ parcial \\
\hline EF194159 & Rabies virus 4372 CthPI 03 / Cerdocyon thous & Brasil & $\mathrm{N}$ parcial \\
\hline EF194163 & Rabies virus 6053CthSE 05 / Cerdocyon thous & Brasil & $\mathrm{N}$ parcial \\
\hline EF194165 & Rabies virus 6335CthPI 05 / Cerdocyon thous & Brasil & $\mathrm{N}$ parcial \\
\hline EF206707 & Rabies strain ERA / linhagem vacinal & Alemanha & $\mathrm{N}, \mathrm{P}, \mathrm{M}, \mathrm{G}$ e L \\
\hline EF206708 & Rabies strain SAD Bern Lysvulpen / linhagem vacinal & República Tcheca & $\mathrm{N}, \mathrm{P}, \mathrm{M}, \mathrm{G}$ e L \\
\hline EF206709 & Rabies strain SAD B19 Fuchsoral / linhagem vacinal & Alemanha & $\mathrm{N}, \mathrm{P}, \mathrm{M}, \mathrm{G}$ e L \\
\hline EF206710 & Rabies SAD Bern original var 1 / linhagem vacinal & Suíça & $\mathrm{N}, \mathrm{P}, \mathrm{M}, \mathrm{G}$ e L \\
\hline EF206711 & Rabies SAD Bern original var 2 / linhagem vacinal & Suíça & $\mathrm{N}, \mathrm{P}, \mathrm{M}, \mathrm{G}$ e L \\
\hline EF206712 & Rabies SAD Bern original var 3 / linhagem vacinal & Suíça & $\mathrm{N}, \mathrm{P}, \mathrm{M}, \mathrm{G}$ e L \\
\hline EF206713 & Rabies SAD Bern original var 4 / linhagem vacinal & Suíça & $\mathrm{N}, \mathrm{P}, \mathrm{M}, \mathrm{G}$ e L \\
\hline EF206714 & Rabies SAD Bern original var 5 / linhagem vacinal & Suíça & $\mathrm{N}, \mathrm{P}, \mathrm{M}, \mathrm{G}$ e L \\
\hline EF206715 & Rabies SAD P5 88 Rabifox / linhagem vacinal & Alemanha & $\mathrm{N}, \mathrm{P}, \mathrm{M}, \mathrm{G}$ e L \\
\hline EF206716 & Rabies SAD VA1 original / linhagem vacinal & Alemanha & $\mathrm{N}, \mathrm{P}, \mathrm{M}, \mathrm{G}$ e L \\
\hline EF206717 & Rabies strain SAD1 3670 var 1 / linhagem vacinal & Alemanha & $\mathrm{N}, \mathrm{P}, \mathrm{M}, \mathrm{G}$ e L \\
\hline EF206718 & Rabies strain SAD1 3670 var 2 / linhagem vacinal & Alemanha & $\mathrm{N}, \mathrm{P}, \mathrm{M}, \mathrm{G}$ e L \\
\hline EF206719 & Rabies strain SAG 2 / linhagem vacinal & França & $\mathrm{N}, \mathrm{P}, \mathrm{M}, \mathrm{G}$ e L \\
\hline EF206720 & Rabies strain SAD Bern Sanafox / linhagem vacinal & Alemanha & $\mathrm{N}, \mathrm{P}, \mathrm{M}, \mathrm{G}$ e L \\
\hline EF363743 & Rabies virus IP3067_04 / Homo sapiens & Brasil & $\mathrm{N}$ parcial \\
\hline EF363751 & Rabies virus IP5214_04 / Homo sapiens & Brasil & $\mathrm{N}$ parcial \\
\hline EF363757 & Rabies virus IP7541_05 / Homo sapiens & Brasil & $\mathrm{N}$ parcial \\
\hline EF437215 & Rabies isolate NNV RAB H / Homo sapiens & Índia & $\mathrm{N}, \mathrm{P}, \mathrm{M}, \mathrm{G}$ e L \\
\hline EF508140 & Rabies virus isolate PA30 / Procyon lotor & Estados Unidos & $\mathrm{N}$ \\
\hline EF542830 & Rabies strain RV 97 / linhagem vacinal & Rússia & $\mathrm{N}, \mathrm{P}, \mathrm{M}, \mathrm{G}$ e L \\
\hline EF564174 & Rabies strain CTN181 / Homo sapiens & China & $\mathrm{N}, \mathrm{P}, \mathrm{M}, \mathrm{G}$ e L \\
\hline EU004771 & Rabies virus isolate CHN0615D / Canis familiaris & China & $\mathrm{P}$ \\
\hline EU004772 & Rabies virus isolate CHN0517D /Canis familiaris & China & $\mathrm{P}$ \\
\hline EU004773 & Rabies virus isolate CHN0528D / Canis familiaris & China & $\mathrm{P}$ \\
\hline EU004774 & Rabies virus isolate CHN0532D / Canis familiaris & China & $\mathrm{P}$ \\
\hline EU004775 & Rabies virus isolate CHN0633D / Canis familiaris & China & $\mathrm{P}$ \\
\hline EU004776 & Rabies virus isolate CHN0610HD / Homo sapiens & China & $\mathrm{P}$ \\
\hline EU004777 & Rabies virus isolate $\mathrm{CHN} 0635 \mathrm{H} /$ Homo sapiens & China & $\mathrm{P}$ \\
\hline
\end{tabular}




\begin{tabular}{|c|c|c|c|}
\hline No Acesso GenBank & Identificação (Hospedeiro / Linhagem) & Origem & Gene \\
\hline EU004778 & Rabies virus isolate CHN0642D / Canis familiaris & China & $\mathrm{P}$ \\
\hline EU004779 & Rabies virus isolate CHN0701D / Canis familiaris & China & $\mathrm{P}$ \\
\hline EU004780 & Rabies virus isolate CJS0621D / Canis familiaris & China & $\mathrm{P}$ \\
\hline EU004781 & Rabies virus isolate CJS0622D / Canis familiaris & China & $\mathrm{P}$ \\
\hline EU004782 & Rabies virus isolate CJS0523D / Canis familiaris & China & $\mathrm{P}$ \\
\hline EU004783 & Rabies virus isolate CJS0635D / Canis familiaris & China & $\mathrm{P}$ \\
\hline EU004784 & Rabies virus isolate CJS0636D / Canis familiaris & China & $\mathrm{P}$ \\
\hline EU004785 & Rabies virus isolate CJS0538D / Canis familiaris & China & $\mathrm{P}$ \\
\hline EU004786 & Rabies virus isolate CJS0639D / Canis familiaris & China & $\mathrm{P}$ \\
\hline EU004787 & Rabies virus isolate CYN0601H / Homo sapiens & China & $\mathrm{P}$ \\
\hline EU004788 & Rabies virus isolate $\mathrm{CYN} 0701 \mathrm{H} /$ Homo sapiens & China & $\mathrm{P}$ \\
\hline EU182346 & Rabies strain RB E3 15 / linhagem vacinal & China & $\mathrm{N}, \mathrm{P}, \mathrm{M}, \mathrm{G}$ e L \\
\hline EU182347 & Mutant Rabies strain Rb E3 155 / linhagem vacinal & China & $\mathrm{N}, \mathrm{P}, \mathrm{M}, \mathrm{G}$ e L \\
\hline EU293111 & Rabies isolate 8764THA / Homo sapiens & Tailândia & $\mathrm{N}, \mathrm{P}, \mathrm{M}, \mathrm{G}$ e L \\
\hline EU293113 & Rabies isolate 9001FRA / Canis familiaris & Guiana & $\mathrm{N}, \mathrm{P}, \mathrm{M}, \mathrm{Ge} \mathrm{L}$ \\
\hline EU293115 & Rabies isolate 9147FRA / raposa & França & $\mathrm{N}, \mathrm{P}, \mathrm{M}, \mathrm{G}$ e L \\
\hline EU293116 & Rabies virus isolate 9704ARG / Tadarida brasiliensis & Argentina & $\mathrm{N}, \mathrm{P}, \mathrm{M}, \mathrm{G}$ e L \\
\hline EU293121 & Rabies isolate 8743THA / Homo sapiens & Tailândia & $\mathrm{N}, \mathrm{P}, \mathrm{M}, \mathrm{G}$ e L \\
\hline EU311738 & Rabies isolate RRV ON 992 / Procyon lotor & Canadá & $\mathrm{N}, \mathrm{P}, \mathrm{M}, \mathrm{G}$ e L \\
\hline EU549783 & Rabies strain BD06 / linhagem vacinal & China & $\mathrm{N}, \mathrm{P}, \mathrm{M}, \mathrm{G}$ e L \\
\hline EU643590 & Rabies strain HN10 / Homo sapiens & China & $\mathrm{N}, \mathrm{P}, \mathrm{M}, \mathrm{G}$ e L \\
\hline EU877067 & Rabies strain SAD B19 4th / linhagem vacinal & Alemanha & $\mathrm{N}, \mathrm{P}, \mathrm{M}, \mathrm{G}$ e L \\
\hline EU877068 & Rabies strain SAD B19 1st / linhagem vacinal & Alemanha & $\mathrm{N}, \mathrm{P}, \mathrm{M}, \mathrm{G}$ e L \\
\hline EU877069 & Rabies strain SAD B19 1st / linhagem vacinal & Alemanha & $\mathrm{N}, \mathrm{P}, \mathrm{M}, \mathrm{G}$ e L \\
\hline EU877070 & Rabies strain SAD B19 5th / linhagem vacinal & Alemanha & $\mathrm{N}, \mathrm{P}, \mathrm{M}, \mathrm{G}$ e L \\
\hline EU877071 & Rabies strain SAD B19 10th / linhagem vacinal & Alemanha & $\mathrm{N}, \mathrm{P}, \mathrm{M}, \mathrm{G}$ e L \\
\hline EU886632 & Rabies collection 2002 / raposa vermelha & Alemanha & $\mathrm{N}, \mathrm{P}$ e M \\
\hline EU886633 & Rabies collection 2004 / raposa vermelha & Austria & $\mathrm{N}, \mathrm{P}$ e M \\
\hline EU886635 & Rabies collection 2005 / raposa vermelha & Alemanha & $\mathrm{N}, \mathrm{P}$ e M \\
\hline FJ415313 & $\begin{array}{l}\text { Rabies virus isolate NeiMeng925 / Nyctereutes procyonoides - } \\
\text { Raccoon-dog }\end{array}$ & China & $\mathrm{M}$ e P \\
\hline FJ465387 & Rabies virus 2800 / Galerella sanguinea (mangusto) & África do Sul & G \\
\hline FJ465401 & Rabies virus 42090 / Cynictis penicillata (mangusto amarelo) & África do Sul & G \\
\hline FJ465403 & Rabies virus 71898 / Genetta genetta & África do Sul & $\mathrm{G}$ \\
\hline FJ542364 & Rabies virus strain Oaxaca California / Homo sapiens & Estados Unidos & $\mathrm{N}$ \\
\hline FJ577895 & Rabies strain Flury LEP C / linhagem vacinal & China & $\mathrm{N}, \mathrm{P}, \mathrm{M}, \mathrm{G}$ e L \\
\hline FJ712193 & Rabies isolate D01 / Canis familiaris & China & $\mathrm{N}, \mathrm{P}, \mathrm{M}, \mathrm{Ge} \mathrm{L}$ \\
\hline FJ712194 & Rabies isolate D02 / Canis familiaris & China & $\mathrm{N}, \mathrm{P}, \mathrm{M}, \mathrm{G}$ e L \\
\hline FJ712195 & Rabies isolate F02 / Canis familiaris & China & $\mathrm{N}, \mathrm{P}, \mathrm{M}, \mathrm{G}$ e L \\
\hline FJ712196 & Rabies isolate F04 / Melogale moschata (ferret) & China & $\mathrm{N}, \mathrm{P}, \mathrm{M}, \mathrm{G}$ e L \\
\hline FJ866835 & Rabies strain FJ008 / Melogale moschata (ferret) & China & $\mathrm{N}, \mathrm{P}, \mathrm{M}, \mathrm{G}$ e L \\
\hline FJ866836 & Rabies strain FJ009 / Melogale moschata (ferret) & China & $\mathrm{N}, \mathrm{P}, \mathrm{M}, \mathrm{G}$ e L \\
\hline FJ913470 & Rabies strain ERA VC / linhagem vacinal & China & $\mathrm{N}, \mathrm{P}, \mathrm{M}, \mathrm{G}$ e L \\
\hline FJ959397 & Rabies strain CTN 1 / linhagem vacinal & China & $\mathrm{N}, \mathrm{P}, \mathrm{M}, \mathrm{G}$ e L \\
\hline GQ233040 & Rabies virus glycoprotein / Canis familiaris & India & G \\
\hline GQ303556 & Rabies virus isolate D9 52 / Canis familiaris & Tailândia & $\mathrm{N}$ \\
\hline GQ472505 & Rabies virus strain GXWX / suíno & China & $\mathrm{P}$ \\
\hline
\end{tabular}




\begin{tabular}{|c|c|c|c|}
\hline No Acesso GenBank & Identificação (Hospedeiro / Linhagem) & Origem & Gene \\
\hline GQ472549 & Rabies virus GXLA / Canis lupus familiaris & China & G \\
\hline GQ472550 & Rabies virus GXLB / Canis lupus familiaris & China & G \\
\hline GQ472551 & Rabies virus GXLCC / Canis lupus familiaris & China & G \\
\hline GQ472552 & Rabies virus GXN119 / Canis lupus familiaris & China & G \\
\hline GQ472553 & Rabies virus GXNN2 / Canis lupus familiaris & China & G \\
\hline GQ472554 & Rabies virus GXNND / Canis lupus familiaris & China & G \\
\hline GQ472555 & Rabies virus GXPL / Canis lupus familiaris & China & G \\
\hline GQ472556 & Rabies virus GXPXD / Canis lupus familiaris & China & G \\
\hline GQ472557 & Rabies virus GXQZD / Canis lupus familiaris & China & G \\
\hline GQ472558 & Rabies virus GXSL / Bos taurus & China & G \\
\hline GQ472559 & Rabies virus GXWX / suíno & China & G \\
\hline GQ472560 & Rabies virus GXYZD / Canis lupus familiaris & China & G \\
\hline GQ918139 & Rabies strain CVS 11 / linhagem vacinal & França & $\mathrm{N}, \mathrm{P}, \mathrm{M}, \mathrm{G}$ e L \\
\hline GU345746 & Rabies isolate CQ92 / Canis familiaris & China & $\mathrm{N}, \mathrm{P}, \mathrm{M}, \mathrm{G}$ e L \\
\hline GU345747 & Rabies isolate J / Homo sapiens & China & $\mathrm{N}, \mathrm{P}, \mathrm{M}, \mathrm{G}$ e L \\
\hline GU345748 & Rabies isolate SH06 / Canis familiaris & China & $\mathrm{N}, \mathrm{P}, \mathrm{M}, \mathrm{G}$ e L \\
\hline GU358653 & Rabies isolate GX4 / Canis familiaris & China & $\mathrm{N}, \mathrm{P}, \mathrm{M}, \mathrm{G}$ e L \\
\hline GU565703 & Rabies Flury LEP / linhagem vacinal & China & $\mathrm{N}, \mathrm{P}, \mathrm{M}, \mathrm{G}$ e L \\
\hline GU565704 & Rabies Flury HEP / linhagem vacinal & China & $\mathrm{N}, \mathrm{P}, \mathrm{M}, \mathrm{G}$ e L \\
\hline GU644641 & Rabies virus isolate AZ4030 / Antrozous pallidus & Estados Unidos & $\mathrm{N}$ \\
\hline GU644642 & Rabies virus isolate AZ1968 / Eptesicus fuscus & Estados Unidos & $\mathrm{N}$ \\
\hline GU644643 & Rabies virus isolate AZ7590 / Eptesicus fuscus & Estados Unidos & $\mathrm{N}$ \\
\hline GU644644 & Rabies virus isolate CA237 / Eptesicus fuscus & Estados Unidos & $\mathrm{N}$ \\
\hline GU644645 & Rabies virus isolate CA29 / Eptesicus fuscus & Estados Unidos & $\mathrm{N}$ \\
\hline GU644646 & Rabies virus isolate CA9242 / Eptesicus fuscus & Estados Unidos & $\mathrm{N}$ \\
\hline GU644647 & Rabies virus isolate CAO120 / Eptesicus fuscus & Estados Unidos & $\mathrm{N}$ \\
\hline GU644648 & Rabies virus isolate CA0253 / Eptesicus fuscus & Estados Unidos & $\mathrm{N}$ \\
\hline GU644649 & Rabies virus isolate CA148 Eptesicus fuscus & Estados Unidos & $\mathrm{N}$ \\
\hline GU644650 & Rabies virus isolate CA6860 / Eptesicus fuscus & Estados Unidos & $\mathrm{N}$ \\
\hline GU644651 & Rabies virus isolate CA0100 / Eptesicus fuscus & Estados Unidos & $\mathrm{N}$ \\
\hline GU644652 & Rabies virus isolate GA31940 / Eptesicus fuscus & Estados Unidos & $\mathrm{N}$ \\
\hline GU644653 & Rabies virus isolate GA36568 / Eptesicus fuscus & Estados Unidos & $\mathrm{N}$ \\
\hline GU644654 & Rabies virus isolate IA042 / Eptesicus fuscus & Estados Unidos & $\mathrm{N}$ \\
\hline GU644655 & Rabies virus isolate IA381 / Eptesicus fuscus & Estados Unidos & $\mathrm{N}$ \\
\hline GU644656 & Rabies virus isolate IA543 / Eptesicus fuscus & Estados Unidos & $\mathrm{N}$ \\
\hline GU644657 & Rabies virus isolate MI1251 / Eptesicus fuscus & Estados Unidos & $\mathrm{N}$ \\
\hline GU644658 & Rabies virus isolate MI1271 / Eptesicus fuscus & Estados Unidos & $\mathrm{N}$ \\
\hline GU644659 & Rabies virus isolate MI1406 / Eptesicus fuscus & Estados Unidos & $\mathrm{N}$ \\
\hline GU644660 & Rabies virus isolate MI1586 / Eptesicus fuscus & Estados Unidos & $\mathrm{N}$ \\
\hline GU644661 & Rabies virus isolate MI1672 / Eptesicus fuscus & Estados Unidos & $\mathrm{N}$ \\
\hline GU644662 & Rabies virus isolate MI1833 / Eptesicus fuscus & Estados Unidos & $\mathrm{N}$ \\
\hline GU644663 & Rabies virus isolate MI782 / Eptesicus fuscus & Estados Unidos & $\mathrm{N}$ \\
\hline GU644664 & Rabies virus isolate MI784 / Eptesicus fuscus & Estados Unidos & $\mathrm{N}$ \\
\hline GU644665 & Rabies virus isolate MI1209 / Eptesicus fuscus & Estados Unidos & $\mathrm{N}$ \\
\hline GU644666 & Rabies virus isolate MI1328 / Eptesicus fuscus & Estados Unidos & $\mathrm{N}$ \\
\hline GU644667 & Rabies virus isolate MI1865 / Eptesicus fuscus & Estados Unidos & $\mathrm{N}$ \\
\hline
\end{tabular}




\begin{tabular}{|c|c|c|c|}
\hline No Acesso GenBank & Identificação (Hospedeiro / Linhagem) & Origem & Gene \\
\hline GU644668 & Rabies virus isolate MI1905 / Eptesicus fuscus & Estados Unidos & $\mathrm{N}$ \\
\hline GU644669 & Rabies virus isolate MI399 / Eptesicus fuscus & Estados Unidos & $\mathrm{N}$ \\
\hline GU644670 & Rabies virus isolate MI596 / Eptesicus fuscus & Estados Unidos & $\mathrm{N}$ \\
\hline GU644671 & Rabies virus isolate NJ104 / Eptesicus fuscus & Estados Unidos & $\mathrm{N}$ \\
\hline GU644672 & Rabies virus isolate NJ1049/ Eptesicus fuscus & Estados Unidos & $\mathrm{N}$ \\
\hline GU644673 & Rabies virus isolate NJ1212 / Eptesicus fuscus & Estados Unidos & $\mathrm{N}$ \\
\hline GU644674 & Rabies virus isolate NJ511 / Eptesicus fuscus & Estados Unidos & $\mathrm{N}$ \\
\hline GU644675 & Rabies virus isolate NJ949 / Epstesicus fuscus & Estados Unidos & $\mathrm{N}$ \\
\hline GU644676 & Rabies virus isolate VA1623 / Eptesicus fuscus & Estados Unidos & $\mathrm{N}$ \\
\hline GU644677 & Rabies virus isolate VA2057 / Eptesicus fuscus & Estados Unidos & $\mathrm{N}$ \\
\hline GU644678 & Rabies virus isolate WA0355 / Eptesicus fuscus & Estados Unidos & $\mathrm{N}$ \\
\hline GU644679 & Rabies virus isolate WA369 / Eptesicus fuscus & Estados Unidos & $\mathrm{N}$ \\
\hline GU644680 & Rabies virus isolate WA052 / Eptesicus fuscus & Estados Unidos & $\mathrm{N}$ \\
\hline GU644681 & Rabies virus isolate WA173 / Eptesicus fuscus & Estados Unidos & $\mathrm{N}$ \\
\hline GU644682 & Rabies virus isolate WA267 / Eptesicus fuscus & Estados Unidos & $\mathrm{N}$ \\
\hline GU644683 & Rabies virus isolate WA1043 / Eptesicus fuscus & Estados Unidos & $\mathrm{N}$ \\
\hline GU644684 & Rabies virus isolate WA1087 / Eptesicus fuscus & Estados Unidos & $\mathrm{N}$ \\
\hline GU644685 & Rabies virus isolate WA1159/ Eptesicus fuscus & Estados Unidos & $\mathrm{N}$ \\
\hline GU644686 & Rabies virus isolate WA016 / Eptesicus fuscus & Estados Unidos & $\mathrm{N}$ \\
\hline GU644687 & Rabies virus isolate WA1455 / Eptesicus fuscus & Estados Unidos & $\mathrm{N}$ \\
\hline GU644688 & Rabies virus isolate WA1586 / Eptesicus fuscus & Estados Unidos & $\mathrm{N}$ \\
\hline GU644689 & Rabies virus isolate WA1596 / Eptesicus fuscus & Estados Unidos & $\mathrm{N}$ \\
\hline GU644690 & Rabies virus isolate WA1625 / Eptesicus fuscus & Estados Unidos & $\mathrm{N}$ \\
\hline GU644691 & Rabies virus isolate WA50 / Eptesicus fuscus & Estados Unidos & $\mathrm{N}$ \\
\hline GU644692 & Rabies virus isolate WA1770 / Eptesicus fuscus & Estados Unidos & $\mathrm{N}$ \\
\hline GU644693 & Rabies virus isolate WA1833 / Eptesicus fuscus & Estados Unidos & $\mathrm{N}$ \\
\hline GU644694 & Rabies virus isolate WA1858 / Eptesicus fuscus & Estados Unidos & $\mathrm{N}$ \\
\hline GU644695 & Rabies virus isolate WA2017 / Eptesicus fuscus & Estados Unidos & $\mathrm{N}$ \\
\hline GU644696 & Rabies virus isolate CA16461 / Lasiurus blossevillii & Estados Unidos & $\mathrm{N}$ \\
\hline GU644697 & Rabies virus isolate CA0077 / Lasiurus blossevillii & Estados Unidos & $\mathrm{N}$ \\
\hline GU644698 & Rabies virus isolate FL701 / Lasiurus borealis & Estados Unidos & $\mathrm{N}$ \\
\hline GU644699 & Rabies virus isolate FL854 / Lasiurus borealis & Estados Unidos & $\mathrm{N}$ \\
\hline GU644700 & Rabies virus isolate GA60243 / Lasiurus borealis & Estados Unidos & $\mathrm{N}$ \\
\hline GU644701 & Rabies virus isolate MI1625 / Lasiurus borealis & Estados Unidos & $\mathrm{N}$ \\
\hline GU644702 & Rabies virus isolate NJ2262 / Lasiurus borealis & Estados Unidos & $\mathrm{N}$ \\
\hline GU644703 & Rabies virus isolate TN132 / Lasiurus borealis & Estados Unidos & $\mathrm{N}$ \\
\hline GU644704 & Rabies virus isolate TN269 / Lasiurus borealis & Estados Unidos & $\mathrm{N}$ \\
\hline GU644705 & Rabies virus isolate $\mathrm{TN} 33$ / Lasiurus borealis & Estados Unidos & $\mathrm{N}$ \\
\hline GU644706 & Rabies virus isolate TX4843 / Lasiurus borealis & Estados Unidos & $\mathrm{N}$ \\
\hline GU644707 & Rabies virus isolate TX6070/Lasiurus borealis & Estados Unidos & $\mathrm{N}$ \\
\hline GU644708 & Rabies virus isolate TX2356/Lasiurus borealis & Estados Unidos & $\mathrm{N}$ \\
\hline GU644709 & Rabies virus isolate TX5276/Lasiurus borealis & Estados Unidos & $\mathrm{N}$ \\
\hline GU644710 & Rabies virus isolate TX5751 / Lasiurus borealis & Estados Unidos & $\mathrm{N}$ \\
\hline GU644711 & Rabies virus isolate TX5976/Lasiurus borealis & Estados Unidos & $\mathrm{N}$ \\
\hline GU644712 & Rabies virus isolate $\mathrm{AZ1} 1838$ / Lasiurus cinereus & Estados Unidos & $\mathrm{N}$ \\
\hline GU644713 & Rabies virus isolate AZ5392 / Lasiurus cinereus & Estados Unidos & $\mathrm{N}$ \\
\hline
\end{tabular}




\begin{tabular}{|c|c|c|c|}
\hline No Acesso GenBank & Identificação (Hospedeiro / Linhagem) & Origem & Gene \\
\hline GU644714 & Rabies virus isolate AZ7771 / Lasiurus cinereus & Estados Unidos & $\mathrm{N}$ \\
\hline GU644715 & Rabies virus isolate ID7227 / Lasiurus cinereus & Estados Unidos & $\mathrm{N}$ \\
\hline GU644716 & Rabies virus isolate ID7232 / Lasiurus cinereus & Estados Unidos & $\mathrm{N}$ \\
\hline GU644717 & Rabies virus isolate TN183 / Lasiurus cinereus & Estados Unidos & $\mathrm{N}$ \\
\hline GU644718 & Rabies virus isolate TN410 / Lasiurus cinereus & Estados Unidos & $\mathrm{N}$ \\
\hline GU644719 & Rabies virus isolate WA0524 / Lasiurus cinereus & Estados Unidos & $\mathrm{N}$ \\
\hline GU644720 & Rabies virus isolate WA1617 / Lasiurus cinereus & Estados Unidos & $\mathrm{N}$ \\
\hline GU644721 & Rabies virus isolate WA2085 / Lasiurus cinereus & Estados Unidos & $\mathrm{N}$ \\
\hline GU644722 & Rabies virus isolate FL1024 / Lasiurus intermedius & Estados Unidos & $\mathrm{N}$ \\
\hline GU644723 & Rabies virus isolate FL845 / Lasiurus intermedius & Estados Unidos & $\mathrm{N}$ \\
\hline GU644724 & Rabies virus isolate FL905 / Lasiurus intermedius & Estados Unidos & $\mathrm{N}$ \\
\hline GU644725 & Rabies virus isolate FL978 / Lasiurus intermedius & Estados Unidos & $\mathrm{N}$ \\
\hline GU644726 & Rabies virus isolate FL1165 / Lasiurus intermedius & Estados Unidos & $\mathrm{N}$ \\
\hline GU644727 & Rabies virus isolate TX4904 / Lasiurus intermedius & Estados Unidos & $\mathrm{N}$ \\
\hline GU644728 & Rabies virus isolate TX5433 / Lasiurus intermedius & Estados Unidos & $\mathrm{N}$ \\
\hline GU644729 & Rabies virus isolate TX4350 / Lasiurus intermedius & Estados Unidos & $\mathrm{N}$ \\
\hline GU644730 & Rabies virus isolate ID7376 / Lasionycteris noctivagans & Estados Unidos & $\mathrm{N}$ \\
\hline GU644731 & Rabies virus isolate FL769 / Lasiurus seminolus & Estados Unidos & $\mathrm{N}$ \\
\hline GU644732 & Rabies virus isolate GA7034 / Lasiurus seminolus & Estados Unidos & $\mathrm{N}$ \\
\hline GU644733 & Rabies virus isolate TX6197 / Lasiurus seminolus & Estados Unidos & $\mathrm{N}$ \\
\hline GU644734 & Rabies virus isolate TX5565 / Lasiurus seminolus & Estados Unidos & $\mathrm{N}$ \\
\hline GU644735 & Rabies virus isolate TX5512 / Lasiurus seminolus & Estados Unidos & $\mathrm{N}$ \\
\hline GU644736 & Rabies virus isolate TX5850/ Lasiurus seminolus & Estados Unidos & $\mathrm{N}$ \\
\hline GU644737 & Rabies virus isolate TX6127a / Lasiurus seminolus & Estados Unidos & $\mathrm{N}$ \\
\hline GU644738 & Rabies virus isolate AZ2953 / Lasiurus xanthinus & Estados Unidos & $\mathrm{N}$ \\
\hline GU644739 & Rabies virus isolate CA2070 / Lasiurus xanthinus & Estados Unidos & $\mathrm{N}$ \\
\hline GU644740 & Rabies virus isolate CA06 / Lasiurus xanthinus & Estados Unidos & $\mathrm{N}$ \\
\hline GU644741 & Rabies virus isolate FL1078 / Myotis austroriparius & Estados Unidos & $\mathrm{N}$ \\
\hline GU644742 & Rabies virus isolate FL331 / Myotis austroriparius & Estados Unidos & $\mathrm{N}$ \\
\hline GU644743 & Rabies virus isolate ID7198 / Myotis californicus & Estados Unidos & $\mathrm{N}$ \\
\hline GU644744 & Rabies virus isolate ID7261 / Myotis californicus & Estados Unidos & $\mathrm{N}$ \\
\hline GU644745 & Rabies virus isolate WA1502 / Myotis californicus & Estados Unidos & $\mathrm{N}$ \\
\hline GU644746 & Rabies virus isolate ID7233 / Myotis evotis & Estados Unidos & $\mathrm{N}$ \\
\hline GU644747 & Rabies virus isolate WA2020 / Myotis keenii & Estados Unidos & $\mathrm{N}$ \\
\hline GU644748 & Rabies virus isolate MI1100 / Myotis lucifugus & Estados Unidos & $\mathrm{N}$ \\
\hline GU644749 & Rabies virus isolate MI1367 / Myotis lucifugus & Estados Unidos & $\mathrm{N}$ \\
\hline GU644750 & Rabies virus isolate TN39 / Myotis lucifugus & Estados Unidos & $\mathrm{N}$ \\
\hline GU644751 & Rabies virus isolate AZ2857 / Myotis yumanensis & Estados Unidos & $\mathrm{N}$ \\
\hline GU644752 & Rabies virus isolate CA828 / Myotis yumanensis & Estados Unidos & $\mathrm{N}$ \\
\hline GU644753 & Rabies virus isolate CA957 / Myotis yumanensis & Estados Unidos & $\mathrm{N}$ \\
\hline GU644754 & Rabies virus isolate FL1384 / Nycticeius humeralis & Estados Unidos & $\mathrm{N}$ \\
\hline GU644755 & Rabies virus isolate AZ1258 / Parastrellus hesperus & Estados Unidos & $\mathrm{N}$ \\
\hline GU644756 & Rabies virus isolate CA2167 / Parastrellus hesperus & Estados Unidos & $\mathrm{N}$ \\
\hline GU644757 & Rabies virus isolate IN1657 / Perimyotis subflavus & Estados Unidos & $\mathrm{N}$ \\
\hline GU644758 & Rabies virus isolate TX5168 / Perimyotis subflavus & Estados Unidos & $\mathrm{N}$ \\
\hline GU644759 & Rabies virus isolate CA178 / Corynorhinus townsendii & Estados Unidos & $\mathrm{N}$ \\
\hline
\end{tabular}




\begin{tabular}{|c|c|c|c|}
\hline $\mathbf{N}^{\circ}$ Acesso GenBank & Identificação (Hospedeiro / Linhagem) & Origem & Gene \\
\hline GU644760 & Rabies virus isolate AZ2405 / Tadarida brasiliensis & Estados Unidos & $\mathrm{N}$ \\
\hline GU644761 & Rabies virus isolate AZ2579 / Tadarida brasiliensis & Estados Unidos & $\mathrm{N}$ \\
\hline GU644762 & Rabies virus isolate AZ3086 / Tadarida brasiliensis & Estados Unidos & $\mathrm{N}$ \\
\hline GU644763 & Rabies virus isolate AZ6914 / Tadarida brasiliensis & Estados Unidos & $\mathrm{N}$ \\
\hline GU644764 & Rabies virus isolate AZ982 / Tadarida brasiliensis & Estados Unidos & $\mathrm{N}$ \\
\hline GU644765 & Rabies virus isolate CA0408 / Tadarida brasiliensis & Estados Unidos & $\mathrm{N}$ \\
\hline GU644766 & Rabies virus isolate CA0052 / Tadarida brasiliensis & Estados Unidos & $\mathrm{N}$ \\
\hline GU644767 & Rabies virus isolate CA0299 / Tadarida brasiliensis & Estados Unidos & $\mathrm{N}$ \\
\hline GU644768 & Rabies virus isolate CA15822 / Tadarida brasiliensis & Estados Unidos & $\mathrm{N}$ \\
\hline GU644769 & Rabies virus isolate CA15824 / Tadarida brasiliensis & Estados Unidos & $\mathrm{N}$ \\
\hline GU644770 & Rabies virus isolate CA1984 / Tadarida brasiliensis & Estados Unidos & $\mathrm{N}$ \\
\hline GU644771 & Rabies virus isolate CA2132 / Tadarida brasiliensis & Estados Unidos & $\mathrm{N}$ \\
\hline GU644772 & Rabies virus isolate CA268 / Tadarida brasiliensis & Estados Unidos & $\mathrm{N}$ \\
\hline GU644773 & Rabies virus isolate CA3054 / Tadarida brasiliensis & Estados Unidos & $\mathrm{N}$ \\
\hline GU644774 & Rabies virus isolate CA46 / Tadarida brasiliensis & Estados Unidos & $\mathrm{N}$ \\
\hline GU644775 & Rabies virus isolate CA1032 / Tadarida brasiliensis & Estados Unidos & $\mathrm{N}$ \\
\hline GU644776 & Rabies virus isolate CA96 / Tadarida brasiliensis & Estados Unidos & $\mathrm{N}$ \\
\hline GU644777 & Rabies virus isolate FL148 / Tadarida brasiliensis & Estados Unidos & $\mathrm{N}$ \\
\hline GU644778 & Rabies virus isolate GA093 / Tadarida brasiliensis & Estados Unidos & $\mathrm{N}$ \\
\hline GU644779 & Rabies virus isolate GA112 / Tadarida brasiliensis & Estados Unidos & $\mathrm{N}$ \\
\hline GU644780 & Rabies virus isolate GA135 / Tadarida brasiliensis & Estados Unidos & $\mathrm{N}$ \\
\hline GU644781 & Rabies virus isolate GA187 / Tadarida brasiliensis & Estados Unidos & $\mathrm{N}$ \\
\hline GU644782 & Rabies virus isolate MS076 / Tadarida brasiliensis & Estados Unidos & $\mathrm{N}$ \\
\hline GU644783 & Rabies virus isolate MS079 / Tadarida brasiliensis & Estados Unidos & $\mathrm{N}$ \\
\hline GU644784 & Rabies virus isolate TX5775 / Tadarida brasiliensis & Estados Unidos & $\mathrm{N}$ \\
\hline GU644785 & Rabies virus isolate TX5922 / Tadarida brasiliensis & Estados Unidos & $\mathrm{N}$ \\
\hline GU644786 & Rabies virus isolate TX6344 / Tadarida brasiliensis & Estados Unidos & $\mathrm{N}$ \\
\hline GU644787 & Rabies virus isolate TX7244 / Tadarida brasiliensis & Estados Unidos & $\mathrm{N}$ \\
\hline GU644788 & Rabies virus isolate TX5603 / Tadarida brasiliensis & Estados Unidos & $\mathrm{N}$ \\
\hline GU647092 & Rabies isolate JX08 45 / Melogale moschata & China & $\mathrm{N}, \mathrm{P}, \mathrm{M}, \mathrm{G}$ e L \\
\hline L20672 & Rabies virus RAVN5809FX / Ontario fox & Canadá & $\mathrm{N}$ \\
\hline M13215 & Rabies virus RAVMMGN / clones $\mathrm{pRb}$ - PV strain & França & $\mathrm{N}, \mathrm{P}, \mathrm{M}, \mathrm{G}$ e L \\
\hline M31046 & Rabies virus RAVCGA SAD B19 / linhagem vacinal & Alemanha & $\mathrm{N}, \mathrm{P}, \mathrm{M}, \mathrm{G}$ e L \\
\hline M81059 & Rabies virus RAVGPRA street / Canis familiaris & Argélia & G \\
\hline $\mathrm{U} 22478$ & Rabies virus $9001 \mathrm{GUY} /$ Canis familiaris & Guiana Francesa & $\mathrm{N}$ \\
\hline
\end{tabular}


ANEXO B - Artigo enviado para publicação no Journal of Virological Methods.

Journal of Virological Methods

Manuscript Draft

Title: One-step protocol for amplification of full-length cDNA of the rabies virus genome

Article Type: Research Paper

Keywords: Rabies Virus

Long cDNA

Sequencing

Method Development

Reverse-Transcriptase Polymerase Chain Reaction 
* Manuscript

One-step protocol for amplification of full-length cDNA of the rabies virus genome

Angélica Cristine de Almeida Campos ${ }^{a}$, Fernando Lucas Melo ${ }^{b}$, Camila Malta Romano $^{b, c}$, Danielle Bastos Araujo ${ }^{a}$, Elenice Maria Sequetin Cunha ${ }^{f}$, Débora Regina Veiga Sacramento ${ }^{\mathrm{a}, \mathrm{e}}$, Paolo Marinho de Andrade Zanotto $^{\mathrm{b}}$, Edison Luiz Durigon ${ }^{\mathrm{a}}$ and Silvana Regina Favoretto ${ }^{\mathrm{a}, \mathrm{d}}$

a) Núcleo de Pesquisas em Raiva do Laboratório de Virologia Clínica e Molecular da Universidade de São Paulo, Av Prof. Lineu Prestes, 1374, sala 225 CEP: 05508-900, São Paulo - Brazil

b) Laboratório de Evolução Molecular e Bioinformática, Instituto de Ciências Biomédicas da Universidade de São Paulo, Av Prof. Lineu Prestes, 1374, sala 215 CEP: 05508-900, São Paulo - Brazil

c) Laboratório de Virologia, Instituto de Medicina Tropical da Faculdade de Medicina, Universidade de São Paulo, Av. Professor Enéas de Carvalho Aguiar, 470, CEP: 05403-000, São Paulo - Brazil

d) Instituto Pasteur de São Paulo, Av Paulista, 393, CEP: 01311-000, São Paulo - Brazil

e) Genomic Engenharia Molecular, Rua Itapeva, 500, Cj 5AB, CEP: 01332-903, São Paulo - Brazil

f) Laboratório de Encefalites do Centro de P\&D de Sanidade Animal do Instituto Biológico da Agência Paulista de Tecnologia dos Agronegócios da Secretaria da Agricultura do Estado de São Paulo.

camposac@usp.br or srfavoretto@usp.br

Phone: +55 1130917293 or +55 1175357270 


\section{SUMMARY}

Full-length genome sequencing of the rabies virus is not a routine laboratory procedure. To fully understand the epidemiology, genetic variation and evolution of the rabies virus, full-length viral genomes need to be obtained. For rabies virus studies, cDNA synthesis is usually performed using nonspecific oligonucleotides followed by cloning. When specific primers are used, the cDNA obtained is only partial and is limited to the coding regions. Therefore, the development of methods for synthesizing long cDNA using rabies virus-specific primers is of fundamental importance. A new protocol for the synthesis of long cDNA and the development of 19 new primers are described in this study. This procedure allowed the efficient amplification of the full-length genome of the rabies virus variant maintained by hematophagous bat (Desmodus rotundus) populations following the synthesis of a complete long cDNA. Partial sequencing of the rabies virus genome was performed to confirm rabies-specific PCR amplification. Because degenerate primers were employed, this technique can easily be adapted to other variants. Importantly, this new method is faster and less expensive than cloning methods.

Keywords: Rabies Virus, Long cDNA, Sequencing, Method Development, ReverseTranscriptase Polymerase Chain Reaction 


\section{Introduction}

The Rabies virus, which belongs to the Lyssavirus genus of the Rhabdoviridae family, has a single-stranded, nonsegmented negative-sense RNA genome of about $12 \mathrm{~kb}$ comprising five protein-coding genes, N, P, M, G and L (Tordo, 1996). These genes encode for the nucleoprotein $(N)$, phosphoprotein $(P)$, matrix protein $(M)$, glycoprotein $(\mathrm{G})$ and large, virion-associated transcriptase $(\mathrm{L})$ protein (Tordo et al., 1986a and 1986b; Wunner et al., 1988) and are separated by short intergenic regions and a long pseudogene between the $G$ and $L$ genes. This sequence is flanked by a 3' leader region (Le) and a 5' trailer region (Tr) (Wunner, 2002).

Rabies, an endemic zoonotic virus characterized by acute evolution, is caused by a group of neurotropic viruses that infect domestic and wild animals. Rabies is widely distributed and defies all the available technological resources for control of this disease, resulting in thousands of human deaths worldwide annually. According to the World Health Organization (WHO), rabies is a public health problem that can cause serious environmental and economic damage despite the existence of effective vaccines for human and veterinary use (WHO, 2005).

Species of the Carnivora and Chiroptera orders are recognized as wild reservoirs. Lyssavirus strains that are adapted to bats are genetically different from carnivore-related rabies viruses (WHO, 2005). This fact confirms the need to develop methodologies that allow more precise complementary studies concerning the biology and epidemiology of rabies. Corroborating this idea, Faber et al. (2004) mapped the complete genome of Lasyonicteris noctivagans, an important reservoir of the rabies virus in North America. Given the importance of increased understanding of this virus, Delmas et al. (2008), Szanto et al. (2008) and Mochizuki et al. (2009) 
recently mapped other variants of the rabies virus: one isolated from an insectivore bat, one from Procyon lotor and one from Dusicyon sp. respectively.

The rabies virus strain maintained among populations of hematophagous bats (Desmodus rotundus), which are a natural reservoir for the virus in the region spanning from Mexico to the north of Argentina, causes economic loss to herds. Furthermore, this strain is transmitted to humans, posing a serious public health problem in several countries, particularly in the Amazon region.

In the early 1980s, the development of molecular biology techniques allowed improved diagnostic tests and epidemiological studies regarding the rabies virus. The detection of viral RNA by reverse transcription followed by polymerase chain reaction amplification (RT-PCR) permits diagnosis in tissue samples (Sacramento et al., 1991; Kamolvarin et al., 1993; Whitby et al., 1997; Nadin-Davis, 1998; Heaton et al., 1999; Black et al., 2000; Smith et al., 2000; Echevarría et al., 2001), even in highly decomposed or formalin-fixed samples, from which viral isolation is impossible (David et al., 2002; Favoretto et al., 2005, Rojas-Anaya et al., 2006, Araujo et al., 2008, Lopes et al., 2010). Several research groups have improved these techniques to optimize molecular studies. It is currently possible to distinguish the 11 viral species of the genus Lyssavirus using molecular analysis methods (ICTV, 2009).

For studies involving the rabies virus, cDNA synthesis is usually performed using nonspecific oligonucleotides and cloning. When specific primers are used, only partial cDNA is obtained (Marston et al., 2007; Inoue et al., 2003; Ito et al., 2001a and 2001b).

To create a simple, cost-effective and specific method for studying the Rabies virus, we developed a new protocol for long cDNA synthesis and subsequent 
amplification. Specific primers complementary to the different coding regions of the viral genome and intergenic regions were developed.

Several methods for viral RNA transcription exist; however, these methods, which are intended for the study of short gene fragments, are not efficient enough for the analysis of long gene fragments or complete genomes. The methods used for genetic studies of the rabies virus are usually limited to the transcription of coding genes for different viral proteins. The development of methods for synthesizing long cDNA using specific primers for the rabies virus is therefore of great importance.

\section{Materials and methods}

\subsection{Viral Specimens}

Five different rabies virus samples from four different variants were selected from the Sample Bank of the Center for Rabies Research/Biosafety Level 3 Laboratory of the Clinical and Molecular Virology Laboratory of the Institute of Biomedical Sciences II at the University of Sao Paulo (ICBII-USP), São Paulo-Brazil and maintained at $-70 \stackrel{\circ}{\circ}$. The sample brdrusp01/09 was isolated from hematophagous bats, and antigenic and genetic identification showed that it was

related to the variant maintained among $D$. rotundus bat populations (Accession number GU592648). A first-passage virus was made in Swiss albino mouse brains. The sample brsgusp32/07 was isolated from Brazilian marmosets, and antigenic and genetic identification showed a characteristic pattern of variant maintained by marmosets. The sample brmnusp91/05 was isolated from insectivorous bat (Myotis nigricans) and segregated with samples isolated from insectivorous bats (Accession number HM173087). The sample brcvsusp47/05 was a Challenge Virus Standard maintained in cell culture, and the sample brbvusp01/06 of 
bovine origin was previously characterized as a hematophagous bat variant and utilized as a positive control (Accession number GU592649).

\subsection{Description of the Oligonucleotide Primers}

To determine the complete genome of any rabies virus variant, 19 oligonucleotide primers (Table 1) were designed based on the GenBank published complete genome nucleotide sequence from wild strains (Accession numbers AY705373, AY956319, EF437215) and vaccine strains (AB009663, EF206707, M31046, NC_001542) using OLIGO 6.83 software (Molecular Biology Insights, Inc., Cascade, CO). The same program was used to analyze the quality of the primers by calculating annealing temperatures and assessing the presence of false base-pairing regions and 'hairpins'.

\subsection{Total RNA Extraction}

To each fragment of macerated brain, $500 \mu \mathrm{L}$ of DEPC ${ }^{\circledR} \mathrm{H}_{2} \mathrm{O}$ was added, and samples were vortex homogenized. Total RNA was extracted using $500 \mu \mathrm{L}$ of Trizol LS Reagent ${ }^{\circledR}$ (Invitrogen Corporation, Carlsbad, CA) in an ice bath and refrigerated centrifuge. Two hundred microliters of 25:24:1 phenol:chloroform:isoamyl alcohol (Invitrogen Corporation, Carlsbad, CA) was then added, and samples were vortex homogenized for 15 seconds, chilled on ice for 5 minutes and centrifuged at 12,000x g at $4{ }^{\circ} \mathrm{C}$ for 5 minutes.

After centrifugation, the supernatants were precipitated by adding isopropanol $100 \%$ (v/v) (Sigma-Aldrich Co. St. Louis, MO), and samples were vortex homogenized and incubated on ice for 15 minutes. The mixtures were then 
centrifuged at $12,000 \mathrm{xg}$ for 15 minutes, supernatants were discarded and the pellets were washed with $1 \mathrm{~mL}$ of $75 \%$ ethanol (Merck, Darmstadt, Germany). The suspensions were then centrifuged at $7,500 \mathrm{x} \mathrm{g}$ at $4 \stackrel{\circ}{\circ} \mathrm{C}$ for 8 minutes. The supernatants were again discarded, and after drying, the sediments were resuspended in $30 \mu \mathrm{L}$ of DEPC $\mathrm{H}_{2} \mathrm{O}$ containing $40 \mathrm{U}$ of ribonuclease inhibitor (RNAse OUT, Invitrogen Corporation, Carlsbad, CA).

Quantitation of the extracted RNA was performed using a Thermo Scientific NanoDrop ${ }^{\mathrm{TM}} 1000$ Spectrophotometer (Thermo Fisher Scientific Inc., Waltham, MA).

\subsection{Reverse Transcription Reaction (RT-PCR) - (cDNA Synthesis)}

To synthesize rabies virus long cDNA, the reverse transcription (RT) reaction methodology described below was developed:

Twenty-five microliters of extracted RNA was added to $2 \mu \mathrm{L}$ of $10 \mathrm{mM}$ dNTP (Invitrogen Corporation, Carlsbad, CA) and $5 \mu \mathrm{L}$ of antisense primer $(10 \mathrm{pmol} / \mu \mathrm{L})$, which anneals at the end position of the genome (5' extremity). These samples were then incubated at $65 \stackrel{\circ}{\circ} \mathrm{C}$ for 5 minutes. Nineteen microliters of a second mixture containing $200 \mathrm{U}$ of Reverse Transcriptase (RT) (MMLV - Moloney-murine leukemia virus/Super Script ${ }^{\mathrm{TM}}$ - Invitrogen Corporation, Carlsbad, CA), $8 \mu \mathrm{L}$ of enzyme buffer (50 mM tris- $\mathrm{HCl}, \mathrm{pH} 8.3,75 \mathrm{mM} \mathrm{KCl}, 3 \mathrm{mM} \mathrm{MgCl}$ ), $4 \mathrm{mM} \mathrm{DTT}, 40 \mathrm{U}$ of ribonuclease inhibitor (RNAse OUT, Invitrogen Corporation, Carlsbad, CA) and $\mathrm{H}_{2} \mathrm{O}$ DEPC (Invitrogen Corporation, Carlsbad, CA) were added. The first stage of transcription was performed at $45{ }^{\circ} \mathrm{C}$ for 105 minutes. An additional $200 \mathrm{U}$ of RT (MMLV/Super Script $^{\mathrm{TM}}$ - Invitrogen Corporation, Carlsbad, CA) was then added, and the reaction was incubated for another 105 minutes. After this final reverse transcription step, RT 
was inactivated at $70 \stackrel{\circ}{\mathrm{C}}$ for 15 minutes followed by an incubation of 20 minutes at 37 $\stackrel{\circ}{ } \mathrm{C}$.

\subsection{Polymerase Chain Reaction - (PCR Amplification)}

To amplify each viral gene individually, PCRs were performed using cDNA diluted in 10x reaction buffer, $10 \mathrm{mM}$ Tris- $\mathrm{HCl}(\mathrm{pH} 9.0), 50 \mathrm{mM} \mathrm{KCl}, 2.5 \mathrm{mM} \mathrm{MgCl}$, $200 \mu \mathrm{M}$ of each dNTP, 50 pmol of each primer, $2.5 \mathrm{U}$ of Taq DNA polymerase (Invitrogen Corporation, Carlsbad, CA) and $\mathrm{H}_{2} \mathrm{O}$ DEPC in a final volume of $50 \mu \mathrm{L}$.

In addition to the primers presented in Table 1, a pair of previously described primers (Smith et al., 1995) was also used to amplify and sequence part of the nucleoprotein coding region.

Amplifications were carried out using the following cycling conditions: samples were preheated for 5 minutes at $95 \stackrel{\circ}{ } \mathrm{C}$, subjected to 35 cycles of denaturation for 45 seconds at $94{ }^{\circ} \mathrm{C}$, primer annealing for 45 seconds at temperatures between $45{ }^{\circ} \mathrm{C}$ and $58 \stackrel{\circ}{\circ}$ depending on the pair of primers employed (Table 1) and primer extension for 90 seconds at $72^{\circ} \mathrm{C}$, and terminated with a final extension step for 5 minutes at $72{ }^{\circ} \mathrm{C}$ before being held at $4{ }^{\circ} \mathrm{C}$ in a MasterCycler Gradient Eppendorf thermocycler (Eppendorf AG, Hamburg, Germany). Each PCR experiment included samples lacking RNA template as negative controls and $\mathrm{H}_{2} \mathrm{O}$ as contamination controls. The amplified products were identified by $1.5 \%$ agarose gel electrophoresis (Invitrogen Corporation, Carlsbad, CA) and visualized by ethidium bromide [0.5 $\mu \mathrm{g} / \mathrm{mL}](\mathrm{Edt} \mathrm{Br}$, Sigma-Aldrich Co. St. Louis, MO) staining under UV light. One kilobase DNA markers (Fermentas International Inc., Burlington, Ontario, Canada) were used to determine the size of each product. The results obtained were subsequently documented. 
Double-stranded PCR-amplified products were purified using the ExoSAP-IT system (GE Healthcare Bio-Sciences Ltd - USB Corporation, Cleveland, $\mathrm{OH}$ ) according to the manufacturer's instructions.

To amplify the full-length rabies genome, $300 \mathrm{ng}$ of long cDNA were diluted in 10x reaction buffer, $25 \mathrm{mM}$ dNTP Mix, 40 pmol of each primer (Inicio + Pol 4R), and $2.5 \mathrm{U}$ of Expand Long DNA polymerase (Roche Diagnostics GmbH, Mannheim, Germany) in a final volume of $50 \mu \mathrm{L}$.

The thermal cycling conditions were as follows: 1 cycle of 2 minutes at $94{ }^{\circ} \mathrm{C}$, 20 cycles of 10 seconds at $94^{\circ} \mathrm{C}$, primer annealing for 30 seconds at temperatures between $62{ }^{\circ} \mathrm{C}$ to $54{ }^{\circ} \mathrm{C}$ with a decrease of $-0.5^{\circ} \mathrm{C}$ per cycle and 10 minutes at $68^{\circ} \mathrm{C}$, 25 cycles of 10 seconds at $94^{\circ} \mathrm{C}, 30$ seconds at $53^{\circ} \mathrm{C}$ and 10 minutes at $68^{\circ} \mathrm{C}$ and a final extension step of 10 minutes at $68^{\circ} \mathrm{C}$. PCR products were analyzed by agarose gel electrophoresis and the sizes of products were estimated based on their electrophoretic mobilities relative to those of the $1 \mathrm{~kb}$ DNA ladder (Invitrogen Corporation, Carlsbad, CA).

\subsection{Sequence Reaction and Purification}

Products were quantitated using a Thermo Scientific NanoDrop ${ }^{\mathrm{TM}} 1000$ Spectrophotometer (Thermo Fisher Scientific Inc., Waltham, MA), and 30-100 ng of each product were added to microtubes containing $2 \mu \mathrm{L}$ of $5 x$ Sequencing buffer (Applied Biosystems, Foster City, CA), 3.2 pmol of primer, $2 \mu \mathrm{L}$ of ABI PRISM Dye ${ }^{\mathrm{TM}}$ Terminator Cycle Sequencing Ready Reaction kit (Big Dye v3.1, Applied Biosystems, Foster City, CA) and DEPC water in a final volume of $10 \mu \mathrm{L}$.

The homogenized mixture was placed in a MasterCycler Gradient Eppendorf thermocycler (Eppendorf AG, Hamburg, Germany), denatured for 5 minutes at $96{ }^{\circ} \mathrm{C}$, 
and subjected to 25 cycles of 10 seconds at $96{ }^{\circ} \mathrm{C}, 15$ seconds at $50 \stackrel{\circ}{ } \mathrm{C}$ and 4 minutes at $60 \stackrel{\circ}{ } \mathrm{C}$.

The excess dideoxynucleotide terminators were removed with the Applied

Biosystems Big Dye XTerminator ${ }^{\mathrm{TM}}$ Purification Kit (Applied Biosystems, Foster City, CA) in accordance with the manufacturer's recommendations.

Purified samples were subjected to electrophoresis in POP6 polymer using an automatic sequencer ABI-PRISM model 3100 (Applied Biosystems, Foster City, CA). The samples were automatically tracked using the Automatic DNA Analyzer software package of the ABI-PRISM model 3100.

\subsubsection{Processing and Alignment of the Rabies Virus Sequences}

The nucleotide sequences obtained from individual gene fragments generated after long cDNA amplification was analyzed using the BLAST program (www.ncbi.nlm.nih.gov/blast.html) to confirm amplification of the specific product.

\section{Results}

RNAs were quantitated using a Thermo Scientific NanoDrop ${ }^{\mathrm{TM}} 1000$ Spectrophotometer (Thermo Fisher Scientific Inc., Waltham, MA). The RNA concentrations obtained were above $145.42 \mathrm{ng} / \mu \mathrm{L}$.

The quantity of each cDNA used in PCR reactions was based on the size of the fragment to be amplified. One hundred fifty nanograms of cDNA were used for nucleoprotein, glycoprotein and polymerase, while quantities between 80-150 ng of cDNA were sufficient for amplification of phosphoprotein and matrix genes. 
Positive PCR results were obtained for each rabies genes and for the entire viral genome of the five samples studied and positive control, confirming the viability of long cDNA synthesis (Figures 1).

Figure 1 shows the amplification of the $N, P, M, G$ and $L$ genes generated from the long cDNA. Amplification of the nucleoprotein gene using the Inicio +304 primers produced a single amplicon of 1,550 bp. The primer pairs NPM1F + NPM1R and NPM2F + NPM2R were used to amplify the phosphoprotein and matrix genes, generating fragments of $1,147 \mathrm{bp}$ and 1,224 bp, respectively. As expected, the glycoprotein amplicon was detected at 2,164 bp. A partial amplification of Lpolymerase using the Pol 3F + Final primers was also detected, resulting in a product of $1,699 \mathrm{bp}$.

The complete amplification of the rabies virus genome using the primer pair Inicio + Pol 4R produced a single amplicon of $11,622 \mathrm{bp}$.

To confirm rabies-specific PCR amplification, each product was submitted to direct sequencing of both strands. Following purification, the amplified material was quantitated. For the N, P, M and G genes, between 10 and $30 \mathrm{ng}$ of each purified PCR product was used, while for the polymerase, between 10 and $100 \mathrm{ng}$ of the PCR product was required. Sequence comparisons revealed extensive nucleotide sequence identity between amplified products and representative Lyssaviruses belonging to genotype 1 .

\section{Discussion}

Since the first complete sequence of the fixed rabies virus strain was published in 1986 (Tordo et al. 1986), there have been numerous reports documenting partial rabies genome characterization. The reason for this is that 
generating a single, nearly full-length PCR amplicon using RNA as the template has been relatively difficult. A good strategy for amplification and sequencing of nearly full-length cDNA is therefore needed.

The aims of this study were to optimize a method for synthesizing long cDNA of the rabies virus using a specific primer at the 5' trailer position and to develop new primers that can be employed either for amplification or sequencing based on sequences deposited in GenBank. Previous studies have reported primers that were designed based for a specific group of samples. The primers presented in this paper were designed to be able to detect most rabies virus strains. Based on current knowledge of the rabies virus, these primers bind conserved regions of the genome (Tordo et al., 1986), but contain degenerate oligonucleotides. This feature allows the primers to be used for many variants isolated from different animals. Additionally, melting temperatures near $55^{\circ} \mathrm{C}$ were evaluated to abolish some secondary structural elements and prevent interference with the activity of RT.

Optimal conditions for reverse transcription and PCR amplification were defined, resulting in a simple, sensitive, fast and effective assay for sequencing of nearly full-length rabies virus cDNA from all fresh samples and samples maintained at $-70^{\circ} \mathrm{C}$. Because long cDNA synthesis is performed only once, while synthesizing cDNA for each viral gene would entail repeating the process at least five times, the methods reported here proved to be less expensive and faster than the currently used protocols (Ito et al., 2001; Mochizuki et al., 2009). The fact that samples are manipulated only once also minimizes the risk of contamination or mixed samples, resulting in improved quality control. Moreover, long cDNA synthesis is extremely efficient, allowing for amplification of the complete viral genome, including the 3' leader region. 
Previously reported methods are more complex, can introduce bias and require PCR products to be cloned with a commercially available cloning kit. These methods are more time-consuming and require special equipment, reagents and lab space, resulting in increased cost. Furthermore, in the method described here, the number of reverse transcription reactions is reduced: instead of five gene-specific reactions, this method uses a single reaction. Therefore, this new methodology provides a viable alternative that can be introduced and implemented in any molecular biology laboratory to map the complete genome of the rabies virus.

Studies using the long cDNA are being conducted by several research groups (Marston et al., 2007; Rousseau et al., 2006). The optimization of the time dedicated to laboratorial practice and these techniques will make larger scale analyses possible. It is important to note that PCR amplifications performed using a long cDNA as a template ensure that all fragments amplified come from the same virion instead of from a whole population. Further, this method consists in synthesize a long cDNA molecule and it is ideal for studying the epidemiology of the rabies virus as our results already reflect the currently circulating virus. Finally, this method results in synthesis of a long cDNA molecule, it can be adapted for other viruses, including flavivirus and retroviruses.

The development of new primers and new methodologies that lead to the standardization of laboratory procedures allows a broader variety of questions to be addressed. New data must be obtained to elucidate the role of circulating viral variants and their interaction with their host. Thus, increased numbers of phylogenetic studies will provide a better knowledge of viral evolution and allow for improved decision making regarding the epidemiological control of the rabies virus. 


\section{Acknowledgements}

This work was supported by Sao Paulo Research Foundation - FAPESP Process: 07/01843-0.

\section{References}

Araujo, D.B., Langoni, H., Almeida, M.F., Megid, J., 2008. Heminested reversetranscriptase polymerase chain reaction ( $\mathrm{hnRT}$-PCR) as a tool for rabies vírus detection in stored and decomposed samples. BMC Res. Notes. 4;1:17.

Black, E.M., McElhinney, L.M., Lowings, J.P., Smith, J., Johnstone, P., Heaton, P.R., 2000. Molecular methods to distinguish between classical rabies and the rabiesrelated European bat lyssaviruses. J Virol Methods. 87(1-2):123-31.

David, D., Yakobson, B., Rotenberg, D., Dveres, N., Davidson, I, Stram, Y., 2002. Rabies virus detection by RT-PCR in decomposed naturally infected brains. Vet. Microbiol. 20;87(2):111-8.

Delmas, O., Holmes, E.C., Talbi, C., Larrous, F., Dacheux, L., Bouchier, C., Bourhy, H., 2008. Genomic Diversity and Evolution of the Lyssaviruses. Plos ONE; 3(4): e2057. doi:10.1371/journal.pone.0002057.

Echevarría, J.E., Avellón, A., Juste, J., Vera, M., Ibáñez, C., 2001. Screening of active lyssavirus infection in wild bat populations by viral RNA detection on oropharyngeal swabs. J. Clin. Microbiol. 39(10):3678-83.

Faber, M., Pulmanausahakul, R., Nagao, K., Prosniak, M., Rice, A.B., Koprowski, H., Schnell, M.J., Dietzschold, B., 2004. Identification of viral genomic elements responsible for rabies virus neuroinvasiveness. Proceedings of the National Academy of Sciences USA. 101, 16.328-16.332. 
Favoretto, S.R., Martorelli, L.F., Elkhoury, M.R., Zargo, A.M., Durigon, E.L., 2005. Rabies virus detection and phylogenetic studies in samples from an exhumed human. Clin. Infect. Dis. 1;41(3):413-4.

Heaton, P.R., McElhinney, L.M., Lowings, J.P., 1999. Detection and identification of rabies and rabies-related using rapid-cycle PCR. J. Virol. Methods. 81(1-2):63-9.

ICTV - International Committee on Taxonomy of Viruses. Disponível em: http://www.ictvonline.org/virusTaxonomy.asp?version=2009. Accessed in 17/12/2009.

Inoue, K., Shoji, Y., Kurane, I., lijima, T., Sakai, T., Morimoto, K., 2003. Na Improved method for recovering rabies virus from cloned cDNA. J. Virol. Methods. 107:229236.

Ito, M., Arai, Y.T., Itou, T., Sakai, T., Ito, F.H., Takasaki, T., Kurane, I., $2001 a$. Genetic characterization and geographic distribution of rabies virus isolates in Brazil: identification of two reservoir, dogs and vampire bats. Virology. 284:214-22

Ito, N., Kakemizu, M., Ito, K.A., Yamamoto, A., Yoshida, Y., Sugiyama, M., Minamoto, N., 2001b. A comparison of complete genome sequences of the attenuated RC-HL strain of rabies virus used for production of animal vaccine in Japan, and the parenteral Nishigahara strain. Microbiol. Immunol. 45(1), 51-58.

Kamolvarin, N., Tirawatnpong, T., Rattanasiwamoke, R., Tirawatnpong, S., Panpanich, T., Hemachudha, T., 1993. Diagnosis of rabies by polymerase chain reaction with nested primers. J. Infect. Dis. 167(1):207-10.

Lopes, M.C., Venditti, L.L., Queiroz, L.H., 2010. Comparison between RT-PCR and the mouse inoculation test for detection of rabies virus in samples kept for long periods under different conditions. J. Virol. Methods. 164(1-2):19-23. Epub 2009 Nov 18.

Marston, D.A., McElhinney, L.M., Johnson, N., Müller, T., Conzelmann, K.K., Tordo, N., Fooks, A.R., 2007. Comparative analysis of the full genome sequence of 
European bat lyssavirus type 1 and type 2 with other lyssaviruses and evidence for a conserved transcription termination and polyadenylation motif in the G-L 3 ' nontranslated region. J. Gen. Virol. 88(Pt 4):1302-14.

Mochizuki, N., Kobayashi, Y., Sato, G., Itou, T., Gomes, A.A.B., Ito, F.H., Sakai, T., 2009. Complete genome analysis of a rabies virus isolate from Brazilian wild fox. Arch. Virol. 154(9):1475-88. Epub Aug 23, 2009.

Nadin-Davis, S.A., 1998. Polymerase chain reaction protocols for rabies virus discrimination. J. Virol. Methods. 75(1):1-8.

Rojas-Anaya, E., Loza-Rubio, E., Banda-Ruiz, V.M., Hernández-Baumgarten, E., 2006. Use of reverse transcription polymerase chain reaction to determine the stability of rabies virus genome in brains kept at room temperature. J. Vet. Diagn. Invest. 18:98-101.

Rousseau, C.M., Birditt, B.A., MCkay, A.R., Stoddard, J.N., Lee, T.C., MClaughlin, S., Moore, S.W., Shindo, N., Learn, G.H., Korber, B.T., Brander, C., Goulder, P.J., Kiepiela, P., Walker, B.D., Mullins, J.I., 2006. Large-scale amplification, cloning and sequencing of near full-length HIV-1 subtype C genomes. J. Virol. Methods. 136(12):118-25. Epub May 15, 2006.

Sacramento, D., Bourhy, H., Tordo, N., 1991. PCR technique as an alternative method for diagnosis and molecular epidemiology of rabies virus. Mol. Cel. Probes. 6:229-40.

Smith JS. Rabies virus. In: Murray PR, Baron EJ, Pfaller MA, Tenover FC, Yolken R, editors. Manual of clinical microbiology. 6th ed. Washington: American Society for Microbiology Press; 1995. p. 997-1003.

Smith, J., McElhinney, L.M., Heaton, P.R., Black, E.M., Lowings, J.P., 2000. Assessment of template quality by the incorporation of an internal control into a RTPCR for the detection of rabies and rabies-related viruses. J. Virol. Methods. 
84(2):107-15.

Szanto, A.G., Nadin-Davis, S.A., White, B.N., 2008.Complete genome sequence of a raccoon rabies virus isolate. Virus Res. 136(1-2):130-9. Epub 2008 Jun 11, doi:10.1016/j.virusres.2008.04.029.

Tordo, N., Poch, C., Ermine, A., Keith, G., Rougeon, F., 1986. Walking along the rabies genome: is the large G-L intergenic region a remnant gene? Proc. Natl. Acad. Sci. U S A. 83(11):3914-8.

Tordo, N., Poch, C., Ermine, A., Keith, G., 1986. Primary structure of leader RNA and nucleoprotein genes of the rabies genome: Segmented homology with VSV. Nucleic Acids Res., v. 14, p.2671-2683.

Tordo, N., 1996. Characteristics and molecular biology of rabies vírus. In MESLIN, FX; KAPLAN, MM; KOPROWSKI, H. Laboratory techniques in rabies. Genebra: World Health Organization, p.28-51.

Whitby, J.E., Heaton, P.R., Whitby, H.E., O'Sullivan, E., Johnstone, P., 1997. Rapid detection of rabies and rabies-related viruses by RT-PCR and enzyme-linked immunosorbent assay. J. Virol. Methods. 69(1-2):63-72.

World Health Organization, 2005. WHO Expert Consultation on Rabies. WHO Technical Report Series 931. Geneva: The Organization; In http://www.who.int/rabies/trs931 \%2006 05.pdf. Accessed in 18/08/2006.

Wunner, W.H., Larson, J.K., Dietzschold, B., Smith, C.L., 1988. The molecular biology of rabies viruses. Rev. Infect. Dis. 10 Suppl 4:S771-84. Review.

Wunner, W.H., 2002. Rabies virus. In JACKSON, AC; WUNNER, WH. Rabies. 2Ed. San Diego: Academic Press, p.23-68. 


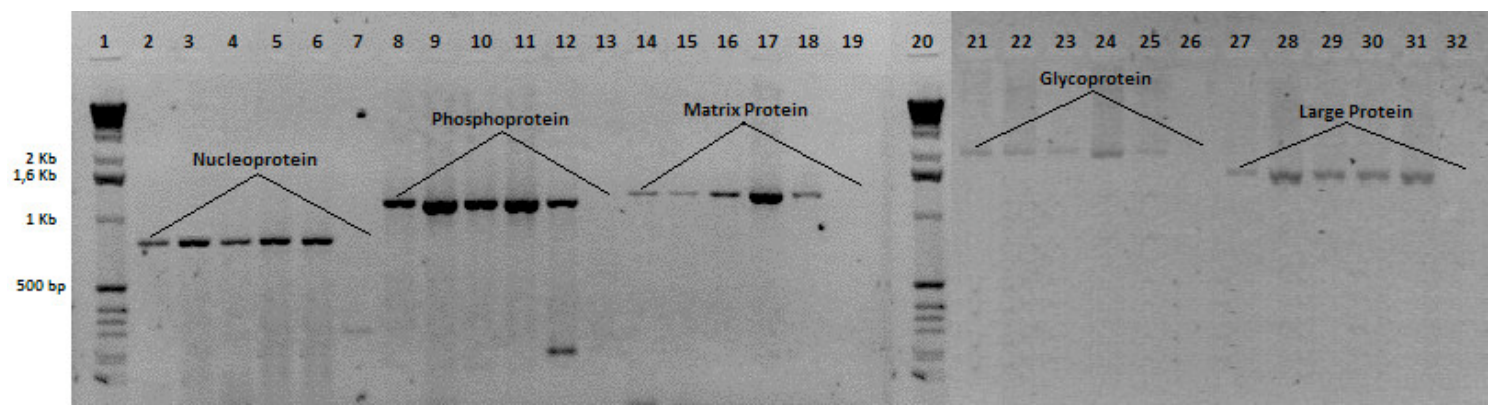

Fig. 1. Ethidium bromide stained $1.5 \%$ agarose gels of amplicons generated from different host samples: brdrusp01/09, brsgusp32/07, brmnusp91/05, CVS strain (brusp47/05), brbvusp01/06 and negative control, respectively. Lanes 1 and 20: DNA size marker 1Kb (Invitrogen). Lanes 7, 13, 19, 26 and 32: negatives controls. Lanes 2 to 6: partial PCR nucleoprotein products (765 pb) amplified with primers SeqN and 304; lanes 8 to 12: PCR phosphoprotein products $(1,147 \mathrm{pb})$ amplified with primers NPM1F and NPM1R; lanes 14 to 18: PCR matrix products (1,224 pb) amplified with primers NMP2F and NPM 2R; lanes 21 to 25: PCR glycoprotein products (2,164 pb) amplified with primers GlycoA and GlycoD; lanes 27 to 31 : PCR products of $1,699 \mathrm{pb}$ from partial $\mathrm{L}$ protein that were amplified with primers sets Pol3F and Final.

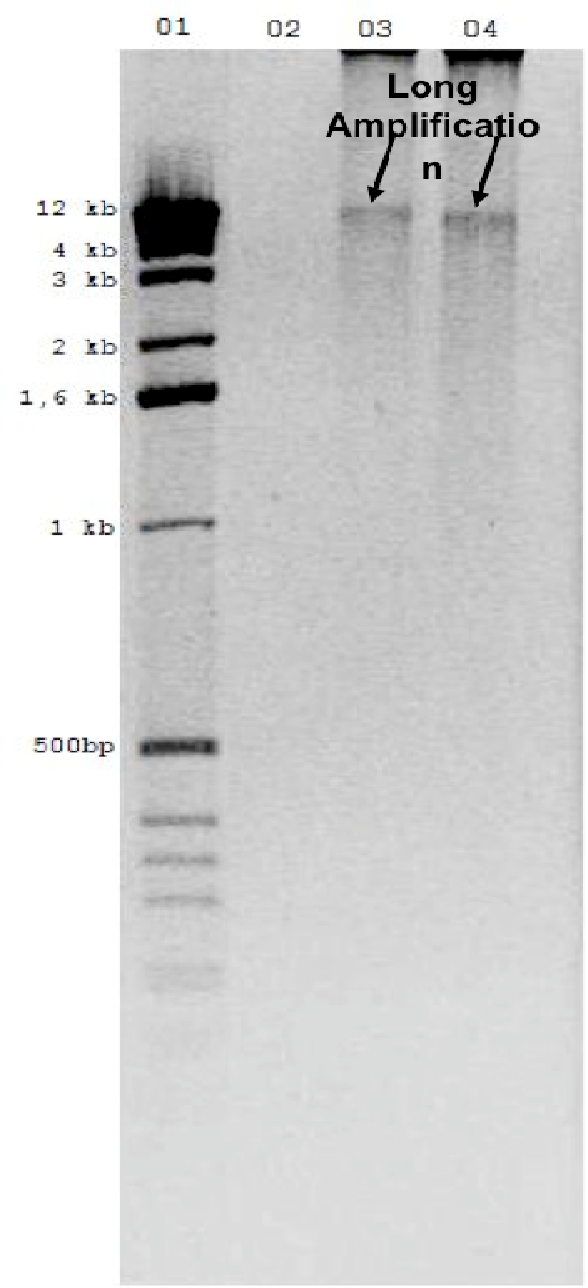

Fig. 2. Agarose gel $1 \%$ stained with ethidium bromide of two amplicons from rabies virus complete genome using long cDNA. Lane 1: DNA size marker $1 \mathrm{~Kb}$ (Invitrogen); lane 2: negative control; lanes 3 and 4: bruspdr01/09 and positive control PCR products of 11,622 bp amplified with primers sets Inicio and Pol 4R. 
Table 1 - Oligos for the amplification and sequencing of rabies virus genome

\begin{tabular}{|c|c|c|c|c|c|}
\hline Primer & Gene Position & Polarity & Sequence & Use & $\begin{array}{c}\text { Annealing } \\
\text { temperature }\end{array}$ \\
\hline Início_Posição1_F & $\begin{array}{c}1-22 \\
\text { Leader }\end{array}$ & + & ACgCTTAACAACAARATCARAg & $\begin{array}{c}\text { PCR and } \\
\text { Sequencing }\end{array}$ & $55^{\circ} \mathrm{C}$ \\
\hline SEQ_NuleoPr_F.750 & $\begin{array}{c}749-766 \\
\text { Nucleoprotein }\end{array}$ & + & ggCACAgTWgTCACTgCT & $\begin{array}{c}\text { PCR and } \\
\text { Sequencing }\end{array}$ & $55^{\circ} \mathrm{C}$ \\
\hline NPM_1_F.1342 & $\begin{array}{c}1342-1361 \\
\text { Nucleoprotein }\end{array}$ & + & TgTCTCAgTCAgYTCCAATC & $\begin{array}{c}\text { PCR and } \\
\text { Sequencing }\end{array}$ & $55^{\circ} \mathrm{C}$ \\
\hline NPM_1_R.2479 & $\begin{array}{c}2480-2501 \\
\text { Phosphoprotein }\end{array}$ & - & gTTCATYTTATCAgTggTgTTg & $\begin{array}{c}\text { PCR and } \\
\text { Sequencing }\end{array}$ & $55^{\circ} \mathrm{C}$ \\
\hline NPM_2_F.2207 & $\begin{array}{c}2207-2226 \\
\text { Phosphoprotein }\end{array}$ & + & ATgAACCTTgATgAYATAgT & $\begin{array}{c}\text { PCR and } \\
\text { Sequencing }\end{array}$ & $50^{\circ} \mathrm{C}$ \\
\hline NPM_2_R.3428 & $\begin{array}{c}3428-3447 \\
\text { Glycoprotein } \\
\end{array}$ & - & ggRCAgCTgAgRTgATgTAT & $\begin{array}{c}\text { PCR and } \\
\text { Sequencing }\end{array}$ & $50^{\circ} \mathrm{C}$ \\
\hline Glyco_F_pcr - A & $\begin{array}{c}\text { 3284-3303 } \\
\text { Intergenic M-G }\end{array}$ & + & CTATCAACATCCCTCAAARg & $\begin{array}{c}\text { PCR and } \\
\text { Sequencing }\end{array}$ & $55^{\circ} \mathrm{C}$ \\
\hline Glyco_F_Sato_pcr-C & $\begin{array}{c}\text { 3219-3237 } \\
\text { Intergenic M-G }\end{array}$ & + & CgCTgCATTTTRTCARAgT & $\begin{array}{c}\text { PCR and } \\
\text { Sequencing }\end{array}$ & $55^{\circ} \mathrm{C}$ \\
\hline Glyco_R_pcr-D & $\begin{array}{c}5426-5443 \\
\text { Pseudogene } \psi\end{array}$ & - & CgggTCATCATARACCTC & $\begin{array}{c}\text { PCR and } \\
\text { Sequencing }\end{array}$ & $55^{\circ} \mathrm{C}$ \\
\hline Glyco_seqF_1 & $\begin{array}{c}3987-4007 \\
\text { Glycoprotein }\end{array}$ & + & gACTTgSggMTTTgTRgATgA & $\begin{array}{c}\text { PCR and } \\
\text { Sequencing }\end{array}$ & $55^{\circ} \mathrm{C}$ \\
\hline Glyco_seqR_1 & $\begin{array}{c}4120-4138 \\
\text { Glycoprotein }\end{array}$ & - & gATCMggRgggCACСАТTT & $\begin{array}{c}\text { PCR and } \\
\text { Sequencing }\end{array}$ & $55^{\circ} \mathrm{C}$ \\
\hline Glyco_seqF_2 & $\begin{array}{c}4120-4138 \\
\text { Glycoprotein }\end{array}$ & + & AAATggTgCCCYCCKgATC & $\begin{array}{c}\text { PCR and } \\
\text { Sequencing }\end{array}$ & $55^{\circ} \mathrm{C}$ \\
\hline Glyco_seqR_2 & $\begin{array}{c}4520-4538 \\
\text { Glycoprotein }\end{array}$ & - & TCCAACARYTCCATATgTT & $\begin{array}{c}\text { PCR and } \\
\text { Sequencing }\end{array}$ & $55^{\circ} \mathrm{C}$ \\
\hline Glyco_seqF_3 & $\begin{array}{c}4370-4390 \\
\text { Glycoprotein }\end{array}$ & + & ggACTTggAACgARRTCATCC & $\begin{array}{c}\text { PCR and } \\
\text { Sequencing }\end{array}$ & $55^{\circ} \mathrm{C}$ \\
\hline Glyco_seqR_3 & $\begin{array}{c}\text { 4637-4656 } \\
\text { Glycoprotein }\end{array}$ & - & gAgAYCTgTTTgTGMACATC & $\begin{array}{c}\text { PCR and } \\
\text { Sequencing }\end{array}$ & $55^{\circ} \mathrm{C}$ \\
\hline GliPol_1_R.6270 & $\begin{array}{c}6270-6287 \\
\text { Glycoprotein }\end{array}$ & - & AgTTTCCRCACATRgACA & $\begin{array}{c}\text { PCR and } \\
\text { Sequencing }\end{array}$ & $55^{\circ} \mathrm{C}$ \\
\hline Pol_3_F.10226 & $\begin{array}{c}10225-10242 \\
\text { L Protein }\end{array}$ & + & gATCARgARgTKCgCCAT & $\begin{array}{c}\text { PCR and } \\
\text { Sequencing }\end{array}$ & $56^{\circ} \mathrm{C}$ \\
\hline Pol_4_R.11616 & $\begin{array}{c}11616-11636 \\
\text { L Protein }\end{array}$ & - & TCCAgTgAgATgAVAgACTCA & $\begin{array}{c}\text { PCR and } \\
\text { Sequencing }\end{array}$ & $56^{\circ} \mathrm{C}$ \\
\hline PosicaoFINAL_R.11904 & $\begin{array}{c}11904-11924 \\
\text { Trailer }\end{array}$ & - & ACgCTTAACAAATAAACAACA & $\begin{array}{l}\text { RT-PCR and } \\
\text { Sequencing }\end{array}$ & $56^{\circ} \mathrm{C}$ \\
\hline
\end{tabular}




\section{ANEXO C - Premiação - Menção Honrosa}

Menção Honrosa recebida durante o XXI Encontro Nacional de Virologia, 2010.

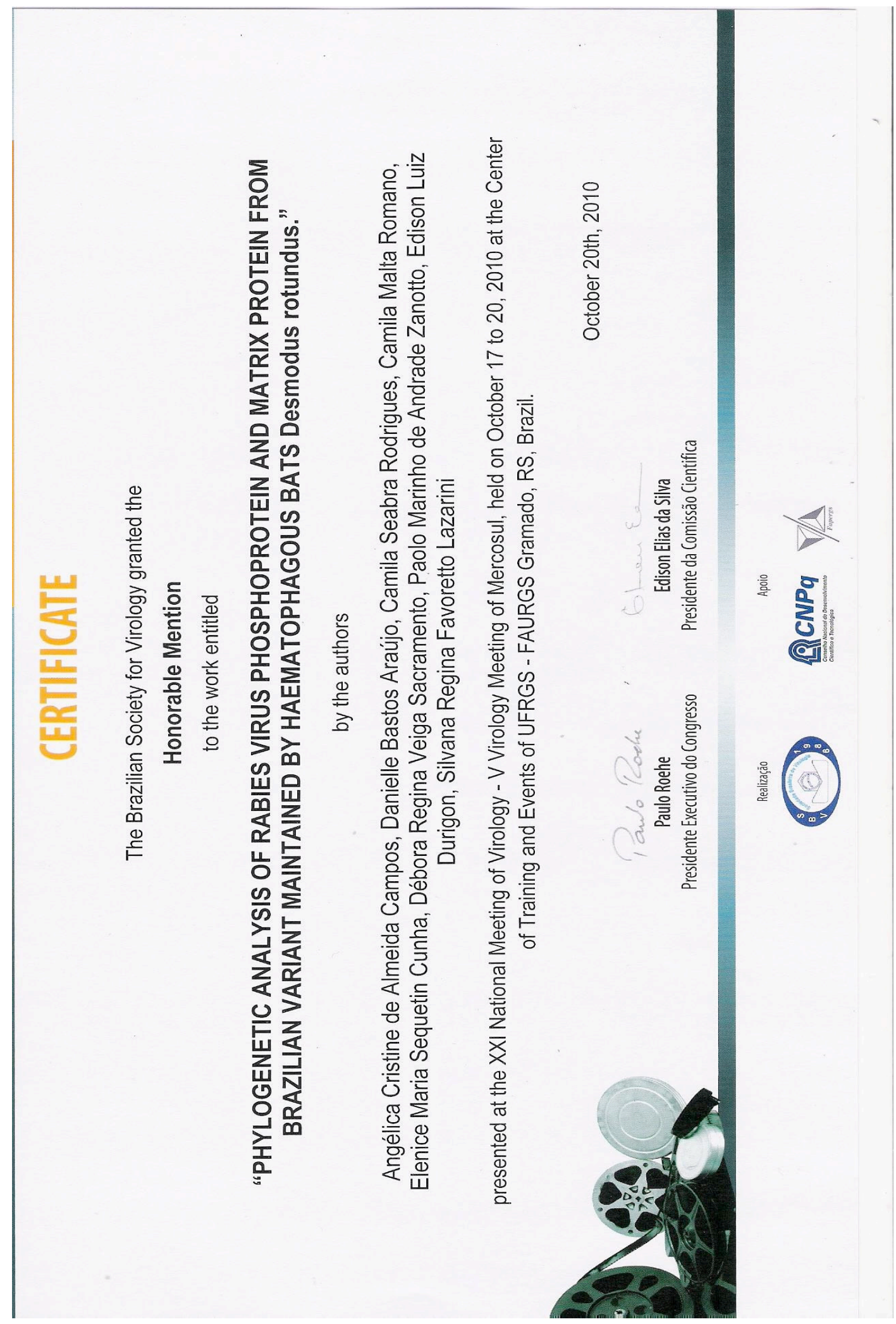

